2. To: (Receiving Organization)

Instrumentation \& Data Acquisition Engineering

5. Proj./Prog./Dept./Div.: 8D340/H25DD

8. Originator Remarks:

APPROVAL/RELEASE

11. Receiver Remarks:
3. From: (Originating Organization)

Instrumentation \& Data Acquisition Engineering

6. Cog. Engr.:

Q. H. Nguyen

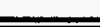

4. Related EDT NO.:

\section{NIA}

7. Purchase Order No.:

NIA

9. Equip./Component No.:

NAA

10. System/Bldg./Facility:

N/A

12. Major Assm. Dwg. No.:

NIA

13. Permit/Permit Application No.: N/A

14. Required Response Date:

$10-94$

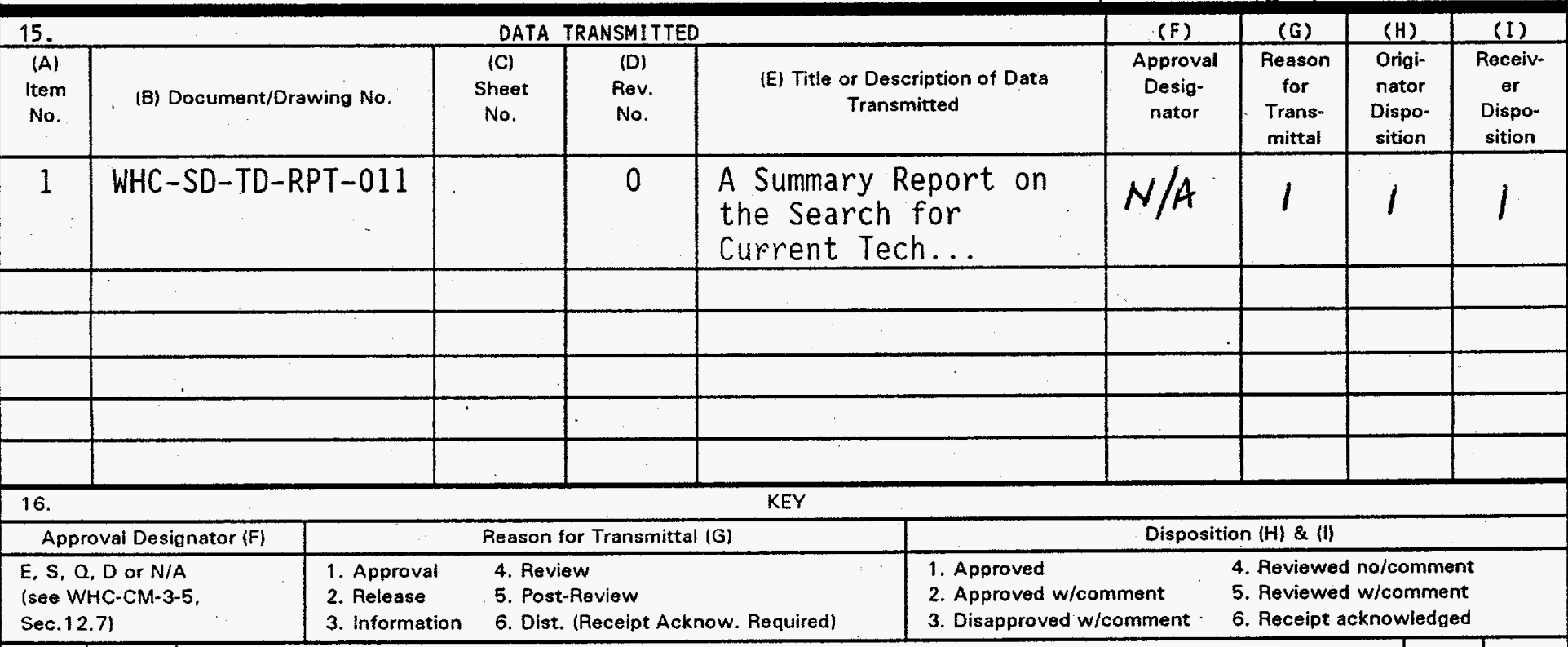

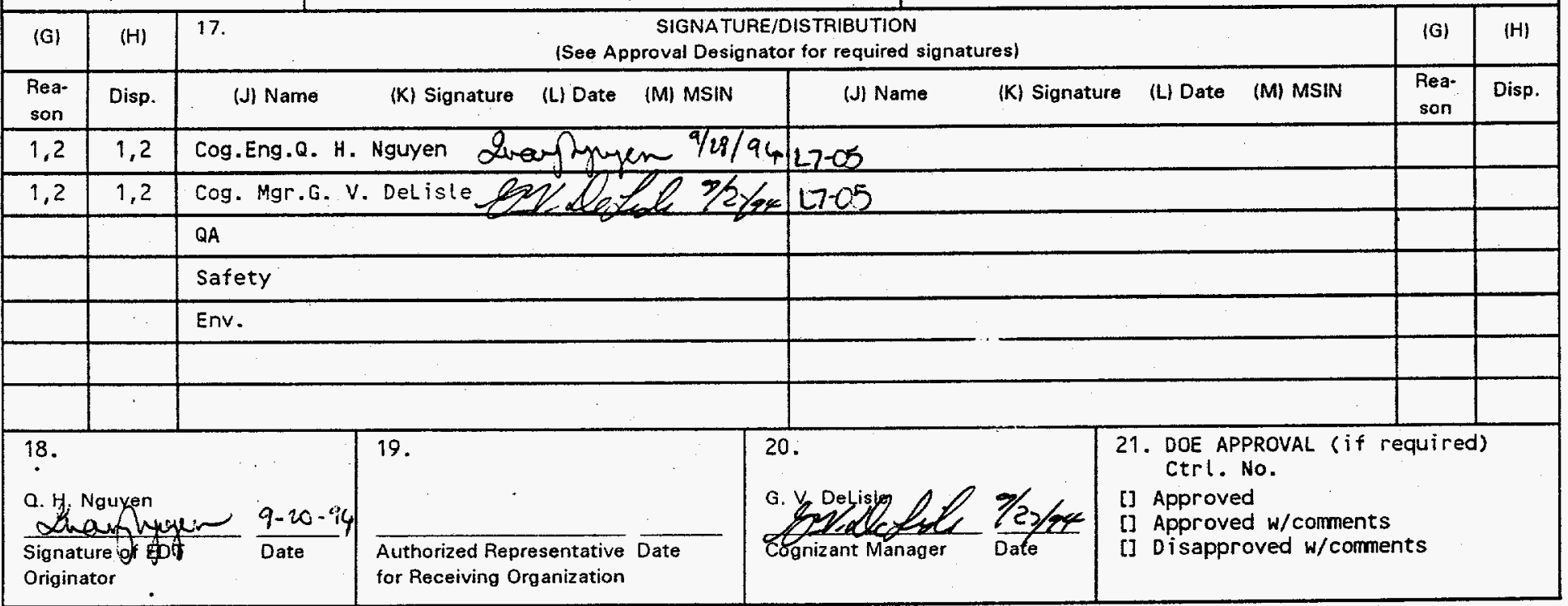




\section{RELEASE AUTHORIZATION}

Document Number: WHC-SD-TD-RPT-011, Revision 0

$\begin{array}{ll}\text { Document Title: } & \begin{array}{l}\text { A Summary Report on the Search for Current } \\ \text { Technologies and Developers to Develop Depth } \\ \text { Profiling/Physical Parameter End Effectors }\end{array}\end{array}$

Release Date: $\quad 10 / 6 / 94$

This document was reviewed following the procedures described in WHC-CM-3-4 and is:

APPROVED FOR PUBLIC RELEASE

$* * * * * * * * * * * * * *$

WHC Information Release Administration Specialist:

M. Boston

M. N. Boston

(Signature)

$10 / 6 / 94$

(Date) 


\section{DISCLAIMER}

Portions of this document may be illegible in electronic image products. Images are produced from the best available original document. 
2. Title

A Summary Report on the Search for Current Technologies and Developers to Develop Depth Profiling/Physical Parameter End Effectors

5. Key Words

Sensor, Depth Profiling, End Effector, Physical Parameters

3. Number

WHC-SD-TD-RPT-011

4. Rev No.

0
6. Author

Name: Q. H. Nguyen

Signature. Organization/Charge Code

\section{Abstract}

This report documents the search strategies and results for available technologies and developers to develop tank waste depth profiling/physical parameter sensors. Sources searched include worldwide research reports, technical papers, journals, private industries, and work at Westinghouse Hanford Company (WHC) at Richland site. Tank waste physical parameters of interest are: abrasiveness, compressive strength, corrosiveness, density, pH, particle size/shape, porosity, radiation, settling velocity, shear strength, shear wave velocity, tensile strength, temperature, viscosity, and viscoelasticity. A list of related articles or sources for each physical parameters is provided.

8. PURPOSE AT6 USZ OF DECUMENT - IXT's Jocumeny was prepared for use withip the 1 .S. Dopartment of Lhergh and $i l s$ contrzttors It is to be used only to perform, Jlrect or integrate/work ander H.S. Department of Energ/ cophracts This dotument is not approyed for publje relase untri yeviewed. PATENT SAatus This docyment coph, siple it is transmitted in zovanes of gatent clearyce, is hade ayor lable in confldence solgty fol use in perfopmance, worl under contacts firl the D.S. Departyent of Energy This tocument ts not to be publ jotied por its tontents otherwise arsseminated of used for purposes other thap opecifled above before patont approtal for such elezse or use tras been segned, upon request, from he Patent Consel, U.S Deparment of Energy Figld offige, Richland, wo.

$\sqrt{\text { DIs }}$

DISCLAIMER - This report was prepared as an account of work sponsored by an agency of the United States Government. Neither the United States Government nor any agency thereof, nor any of their employees, nor any of their contractors, subcontractors or their employees, makes any warranty, express or implied, or assumes any legal liability or responsibility for the accuracy, completeness, or any third party's use or the results of such use of any information, apparatus, product, or process disclosed, or represents that its use would not infringe privately owned rights. Reference herein to any specific commercial product, process, or service by trade name, trademark, manufacturer, or otherwise, does not necessarily constitute or imply its endorsement, recommendation, or favoring by the United States Government or any agency thereof or its contractors or subcontractors. The views and opinions of authors expressed herein do not necessarily state or reflect those of the United States Government or any agency thereof.

10. RELEASE STAMP

OFFIC!AL RELEASE BYWHC DATE OCT 071994

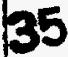

\section{APPROVED FOR PUBLIC RELEASE m. Bostar}

Information Release Administration 
WHC-SD-TD-RPT-011

- Revision 0

A SUMMARY REPORT ON THE SEARCH FOR

CURRENT TECHNOLOGIES AND DEVELOPERS TO DEVELOP

DEPTH PROFILING/PHYSICAL PARAMETER END EFFECTORS

$V_{\text {September } 12,1994}$

Quang $\mathrm{H}$. Nguyen

Westinghouse Hanford Company

P.O. Box 1970

Richland, Washington 99352

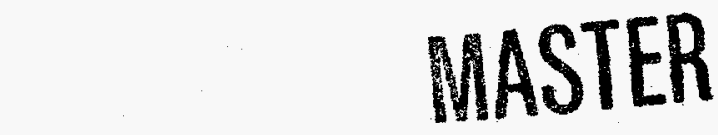

DISTRIEUTION OF THIS DOCUMENT IS UNLMMITED 
WHC-SD-TD-RPT-011

Revision 0

This page intentionally left blank. 
WHC-SD-TD-RPT-011

Revision 0

\title{
A SUMMARY REPORT ON THE SEARCH FOR \\ CURRENT TECHNOLOGIES AND DEVELOPERS TO DEVELOP \\ DEPTH PROFILING/PHYSICAL PARAMETER END EFFECTORS
}

\author{
Q. H. Nguyen
}

\begin{abstract}
This report documents the search strategies and results for available technologies and developers to develop tank waste depth profiling/physical parameter sensors. This document serves as a reference guide to look for available technologies, existing developments, and associate vendor names and addresses that can be applied in the development of sensors to measure tank waste physical parameters. Sources searched include worldwide research reports, technical papers, journals, private industries, and work at Westinghouse Hanford Company (WHC) at Richland site. Resources used in the search are: Battelle Pacific Northwest Library, Kaiser Engineering Hanford. Library, and WHC local network databases. Tank waste physical parameters of interest are: abrasiveness, compressive strength, corrosiveness, density, $\mathrm{pH}$, particle size/shape, porosity, radiation, settling velocity, shear strength, shear wave velocity, tensile strength, temperature, viscosity, and viscoelasticity. A list of related articles or sources for each physical parameters is provided.
\end{abstract}


WHC-SD-TD-RPT-011

Revision 0

This page intentionally left blank.

$\rightarrow$ 
WHC-SD-TD-RPT-011

Revision 0

\section{CONTENTS}

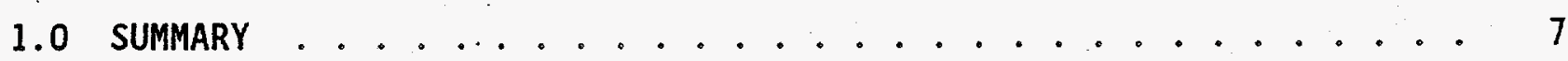

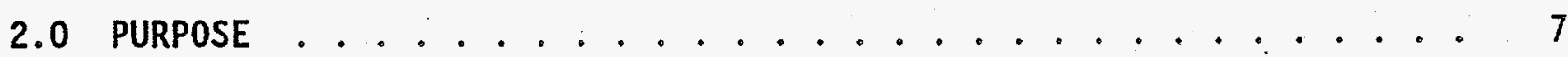

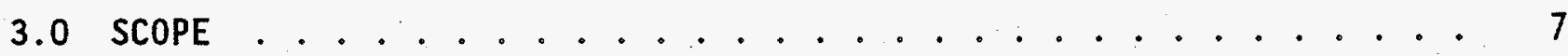

4.0 DEFINITIONS . . . . . . . . . . . . . . . . . . . . . 7

5.0 INTRODUCTION . . . . . . . . . . . . . . 8

6.0 SEARCH SOURCES . . . . . . . . . . . . . . . 8

6.1 WORLDWIDE LITERATURE SEARCH . . . . . . . . . . . . . . . . . 8

6.2 U.S. VENDORS SEARCH . . . . . . . . . . . . . . 9

6.3 WHC INTERNAL WORK SEARCH ............... 9

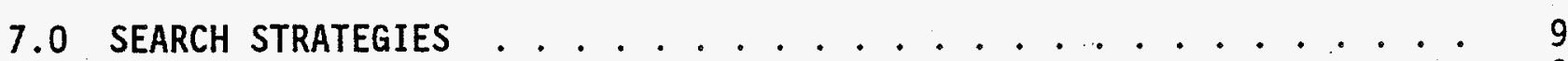

7.1 WORLDWIDE LITERATURE SEARCH . . . . . . . . . . . . . 9

7.2 U.S. VENDORS SEARCH . . . . . . . . . . . . . . 10

7.3 WHC INTERNAL WORK SEARCH ............... 11

8.0 SEARCH RESULTS . . . . . . . . . . . . . . . . . 12

8.1 WORLDWIDE LITERATURE SEARCH . . . . . . . . . . . . 12

8.2 U.S. VENDORS SEARCH . . . . . . . . . . . . . . 12

8.3 WHC INTERNAL WORK SEARCH ............... 12

9.0 SUMMARY . . . . . . . . . . . . . . . . . . . . . . 13

10.0 REFERENCES . . . . . . . . . . . . . . 15

TABLES

7.1. Keywords Used in the Search

for Manufacturers in the U.S. . . . . . . . . . . . . 11

9.1. Possible Methods That Can Be Used

to Measure Tank Waste Physical Parameters . . . . . . . . . 14

9.2. Possible Methods That Can Be Used

For Tank Waste Penetration Device 
WHC-SD-TD-RPT-011

Revision 0

\section{APPENDICES}

A. PHYSICAL PARAMETERS ....................................

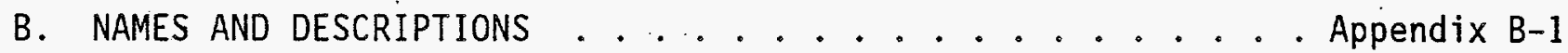

C. WORLDWIDE LITERATURE SEARCH LOG .........................

D. WORLDWIDE LITERATURE SEARCH RESULTS .......................

E. SEARCH RESULTS FOR PHYSICAL PARAMETERS ON CD-ROM MASTER VENDOR CATALOG .......................................

F. SELECTED VENDORS FROM CD-ROM MASTER VENDOR CATALOG SEARCH FOR PHYSICAL PARAMETERS OF TANK WASTE ........... Appendix F-1

G. SEARCH RESULTS FOR DEPTH PENETRATION DEVICE ON CD-ROM MASTER VENDOR CATALOG . . . . . . . . . . . . . . Appendix G-1

H. SELECTED VENDORS FROM CD-ROM MASTER VENDOR CATALOG SEARCH FOR DEPTH PENETRATION DEVICES ...........................

I. ANNOUNCEMENTS IN THE COMMERCE BUSINESS DAILY (CBD) FOR TANK WASTE PHYSICAL PARAMETER AND DEPTH PROFILING SENSORS ..... . Appendix I-I

J. RESPONDED VENDORS LISTING FROM THE ANNOUNCEMENTS IN THE COMMERCE BUSINESS DAILY AND THOSE SELECTED IN APPENDIX F AND $\mathrm{H}$... AppendiX $\mathrm{J}-1$

K: SEARCH RESULTS FROM WHC ENGINEERING RELEASE SYSTEM-DATABASE (ERS-DB)

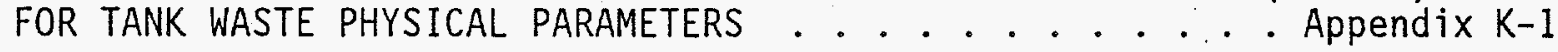

L. SEARCH RESULTS FROM WHC TANK FARM INFO DATABASE (TFI) FOR TANK WASTE

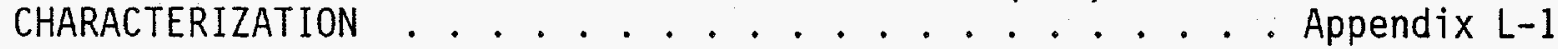


WHC-SD-TD-RPT-011

Revision 0

\section{A SUMMARY REPORT ON. THE SEARCH FOR \\ CURRENT TECHNOLOGIES AND DEVELOPERS TO DEVELOP \\ DEPTH PROFILING/PHYSICAL PARAMETER END EFFECTORS}

\subsection{SUMMARY}

Measurement of tank waste physical parameters is essential to develop design criteria for choosing retrieval equipment and developing tank waste simulant. A list of critical physical parameters of tank waste was defined for these purposes. A depth profiling device is needed to provide an alternative path for deploying sensors to various depths below the tank waste surface. A search for currently available technologies and developers is necessary to locate the most suitable resources for the development of depth profiling and physical parameter sensors. A summary of related technologies and/or developers for each physical parameter/depth profiling end effector is included.

\subsection{PURPOSE}

The purpose of this task is to assemble the corresponding lists of published papers, existing work at WHC, and commercial vendors who have measurement products that can be used to measure tank waste physical parameters or to penetrate tank waste.

\subsection{SCOPE}

A search for the most suited technologies and developers covered worldwide databases for published papers/documents, U.S. vendors master catalogs, and local databases at WHC.

\subsection{DEFINITIONS}

- Sensor: A measuring device or tool used to measure physical parameters of tank waste.

- Depth Profiling: Tank waste penetration device.

- End Effector: A common term for both Sensor and Depth Profiling devices. 
WHC-SD-TD-RPT-011

Revision 0

- Physical Parameters: A general term describing various physical properties, environmental conditions, mechanical properties, elastic properties, etc... of tank waste.

\subsection{INTRODUCTION}

New characterization technologies are being developed to improve timeliness and reduce costs for characterizing tank waste. One goal of the new technology development program (Propson, 1993) is to develop in-situ characterization of tank waste parameters. Tank waste characterization includes the determination of chemical composition, physical properties and forms of tank waste. A list of physical parameters that are applicable to the retrieval process of tank waste was compiled (WHC-SD-WM-RD-039: Bhatia, 1993). This physical parameters list was prioritized (Nguyen, 1994) to provide an order for the development effort of the End Effector (EE).

Many physical characteristics of tank waste are needed to design the retrieval equipment properly (e.g., past-practice sluicing equipment, transfer pumps, Long-Reach Manipulator (LRM) system, mixer pumps). Physical characteristics of tank waste can also be used to develop tank waste simulant for testing and demonstrations of newly developed retrieval systems and components. Appendix A shows a 1 ist of tank waste physical parameters and their descriptions. Some of the selected tank waste physical parameters obtained through core sampling are recorded in "Summary of Tank Waste Physical Properties at the Hanford Site" (Nguyen, 1994). These parameters did not include all tanks.

A comprehensive search on current available technologies was conducted so that the most suitable measurement methods will be used in the design of sensors. Technical information from the search will provide a basis for the selection of methods to be used in the design of the end effectors. Without proper knowledge of today's technologies, a poor decision can lead to an inadequately designed end effector.

\subsection{SEARCH SOURCES}

The search for current technologies and developers of tank waste depth profiling/physical parameter end effectors covers the following three areas:

\subsection{WORLDWIDE LITERATURE SEARCH}

This search was performed through the Pacific Northwest Library in Richland. The search covers seven major databases under separate categories. The databases are: Energy Science and Technology, Ei Compendex Plus, INSPEC, NTIS, PASCAL, SCISEARCH, and SPIN. These databases contain worldwide published papers, government sponsored research and development, and technical 
WHC-SD-TD-RPT-011

Revision 0

literatures of engineering and technology. These seven databases were selected based on the nature of the requested information, which centered around "radioactive waste" and "physical properties measurement." Appendix B provides a brief description of the seven databases used in the search.

\subsection{U.S. VENDORS SEARCH}

A "Vendor Master Directory" on CD-ROM at WHC and ICF Kaiser Hanford were utilized to perform the search for developers/vendors who have related products or are capable of developing the end effectors. The Vendor Master Directory is a catalog database on CD-ROM that has over 20,000 vendors with over 2.7 million manufacturers' catalogs. The search in this area will give a full search coverage of most major manufacturers in the U.S.

\subsection{WHC INTERNAL WORK SEARCH}

A search on local databases at WHC in Richland was performed to guarantee that all previous works at WHC will be utilized without unnecessary duplication. The databases used in this step are the Tank Farm Info (TFI) Database and the Engineering Release System Database (ESR-DB).

\subsection{SEARCH STRATEGIES}

\subsection{WORLDWIDE LITERATURE SEARCH}

The search on seven worldwide databases was performed using keywords located in the title and abstract of the paper. Due to the number of items needed, the literature search is separated into to two searches: (1) the first search covers general physical parameter items (i.e., one keyword is "physical property/ies"), (2) the second search covers each specific item in the physical parameters list. The following lists the combination of keywords that were used in the two searches. Appendix $C$ shows the actual keywords input for the search. In all searches, "AND" operation has precedence over "OR."

Search No 1 Strategy:

radioactive waste $O R$ nuclear waste AND physical property AND

measurement $O R$ detection $O R$ method $O R$ technique

Search No 2 Strategy:

radioactive waste $O R$ nuclear waste AND

NOT physical property AND

measurement OR method AND

detection OR technique AND

sensor $O R$ instrument $O R$ device AND 


\section{WHC-SD-TD-RPT-011}

Revision 0

shear stress $O R$ shear strength $O R$ shear rate $O R$ shear wave $O R$ yield strength $O R$ viscosity $O R$ viscoelasticity $O R$ abrasive $O R$ corrosive $O R$ permeability $O R$ density $O R$ temperature $O R \quad P H O R$ compressive strength $O R$ tensile strength $O R$ porosity OR rheology

All search articles are to be in English only and must be published between 1983 to 199.3. This is necessary to reduce the number of records found.

\subsection{U.S. VENDORS SEARCH}

The U.S. vendor search was performed in two stages:

1. Announcements in the Commerce Business Daily for physical parameters measurement sensors and depth profiling device.

2. Send announcements to selected vendors in the U.S. The selection of U.S. vendors was performed using the CD-ROM Vendor Master Directory: Mar-Apr 1994 Issue.

The "Vendor Master Directory" on CD-ROM was used in this search for vendors within the U.S. Keywords will be used to find potential

manufacturers. Individual physical parameters were used as product keywords in the search. For instance, the keyword "abrasive" will be used to search for all vendors that manufacture or sell products related to the abrasiveness of a material. In some cases, additional descriptions such as soil, cement, and concrete were added to the keywords to refine the search results. Main keywords for depth penetration device searches are "dri17" and "mining." Table 7.1 Tists all keywords used for physical parameters and depth profiling. 
WHC-SD-TD-RPT-011

Revision 0

Table 7.1. Keywords Used in the Search

for Manufacturers in the U.S.

\begin{tabular}{ll}
\hline Physical parameter \\
\hline \\
Abrasive \\
Corrosive \\
Density \\
Moisture \\
pH \\
Porosity \\
Rheology \\
Shear Rate \\
Shear Strength \\
Shear Wave \\
Stress \\
Strength \\
Viscoelasticity \\
Viscosity \\
\\
Depth Penetration \\
\hline Dril \& Cement \\
Dril \& Concrete \\
Dril \& Oil \\
Dril \& Soil \\
Mining \\
\hline
\end{tabular}

Usually the database system will return a list of vendor names. The number of names in the 7 ist can be up to 250 (this is not the maximum number allowed by the program, it depends on the keywords entered). From the results list, a smaller name group is selected based on a brief description of product lines for each company. The announcements in the Commerce Business Daily will. be sent to these selected companies requesting additional information on their products or capabilities.

\subsection{WHC INTERNAL WORK SEARCH}

A Tocal search on WHC databases was necessary to locate previous and/or current development on physical parameter sensors. The databases used in the search is the TFI Database and the ERS-DB. These databases are constantiy being updated as more information becomes available. Therefore, the results documented in this report are valid only to the date that the search was completed. The contents of the ERS-DB include: supporting documents, drawings, Engineering Change Number (ECN), projects, and others. The articles (or records) in the database can be searched by keywords in the title or description of the document. 
WHC-SD-TD-RPT-011

Revision 0

The search on the ERS-DB was completed using individual physical parameters as keywords. The search on the TFI database was based on "characterization" as the keyword. Latest information on a particular project or work can be obtained by further communication with the authors or retrieving referenced documents.

\subsection{SEARCH RESULTS}

\section{1 - WORLDWIDE LITERATURE SEARCH}

Search No 1 resulted in 1011 different records and Search No 2 resulted in 1026 different records. The output from each record includes: title, date, keywords, abstracts, and other keys for identification purposes. The resulting records are available from the author. A 1 ist of all the record. titles are shown in Appendix 0.

\subsection{U.S. VENDORS SEARCH}

Appendix $E$ contains the results from the search for measuring devices of tank waste physical properties. The compressive strength, shear strength, and tensile strength are grouped into one item called "strength". The shear stress and yield stress are grouped into one item called "stress". Appendix F contains the selected vendor names from Appendix $E$ for each physical property.

Appendix $G$ contains the results from the search for the depth penetration device. Appendix $H$ contains the selected vendor names from Appendix $G$.

Announcements in the Commerce Business Daily (CBD) are reproduced in Appendix I. The two advertisements were sent to the selected vendors from Appendix $F$ and $H$. Appendix I lists all vendors who responded to the announcements in the Commerce Business Daily (CBD) and from mail contact through the selected vendors in Appendix $F$ and $H$.

\subsection{WHC INTERNAL WORK SEARCH}

The ERS-DB was used to search for previous and current work at WHC. As described in previous sections, individual. keywords were used to search for documents that have the same item in the title or keywords 7 isting. Appendix $\mathrm{J}$ lists all document titles that were found in the search. In addition, a general search was performed at the Tank Farm Info Center using keyword "characterization." The result from this search is shown in Appendix K. 
WHC-SD-TD-RPT-011

Revision 0

\subsection{SUMMARY}

The search for current technologies and manufacturers was needed to find the most appropriate technology to measure tank waste physical parameters and provide a waste penetration method. The search was performed using the following three search methods:

- Worldwide literature search

- U.S. vendors search

- WHC internal work search

The search results from worldwide literature and U.S. vendors are too numerous. The articles found from the worldwide literature search totalled about 2000 titles. The U.S. vendors search resulted in over 1000 distributors and manufacturers. The search results from previous and current internal work completed at WHC in Richland has about 360 items.

The worldwide literature search and the WHC internal work search were needed to find existing work and technology. The U.S. vendor search was completed to summarize all available manufacturers and distributors for each physical parameter defined. The results from these searches establish a single source of information that can be used as a reference to locate companies, published papers, or related work previously done on a particular physical parameter. Due to the time constraints, it is not feasible to review all articles found nor to request all vendors for additional information. However, this document maintains a valuable source of information for future references. The search methods and strategies used in this document can be repeated if necessary for additional physical parameters that may arise at a later time for different purposes.

Tables 9.1 and 9.2 list relevant sources or technologies for the selected physical parameters described earlier. They are by no means completed because not all found articles were reviewed. The sighted articles or methods were accepted for ideas only. Due to the time constraints, it is not physically possible to review all articles found in this search. The feasibilities of these techniques require further investigation. 
Table 9.1. Possible Methods That Can Be Used to Measure Tank Waste Physical Parameters.

\begin{tabular}{|c|c|c|}
\hline Physical Parameter & Method/Vendor & Reference \\
\hline \multicolumn{3}{|l|}{ Abrasiveness } \\
\hline \multirow[t]{2}{*}{ Compressive Strength } & $\begin{array}{l}\text { Standard Penetration } \\
\text { Test }\end{array}$ & $\begin{array}{l}\text { Ervin, M. C., (Douglas, } \\
\text { D. J.) }\end{array}$ \\
\hline & $\begin{array}{l}\text { Quasi-static } \\
\text { Penetration Testing }\end{array}$ & $\begin{array}{l}\text { Ervin, M. C., } \\
\text { (Sutcliffe, G. and } \\
\text { Waterton, C.) }\end{array}$ \\
\hline \multicolumn{3}{|l|}{ Corrosiveness } \\
\hline \multirow[t]{2}{*}{ Density } & $\begin{array}{l}\text { Standard Penetration } \\
\text { Test }\end{array}$ & $\begin{array}{l}\text { Ervin, M. C., (Douglas, } \\
\text { D.J.) }\end{array}$ \\
\hline & Buoyancy probe & Abdelhamid, M.S. et al. \\
\hline \multirow[t]{2}{*}{$\mathrm{pH}$} & $\begin{array}{l}\text { Sputtered Iridium Oxide } \\
\text { Films (SIROF) }\end{array}$ & Kreiger, K.G. \\
\hline & Silica Fibers (optical) & $\begin{array}{l}\text { Boisde, G. and Perez, } \\
\text { J.J. }\end{array}$ \\
\hline Particle Size/Shape & Focus scanning laser & Galai Instrument, Inc. \\
\hline \multirow[t]{2}{*}{ Porosity } & We11 Logging & \multirow[t]{2}{*}{ Javandel, I. } \\
\hline & Tracer Test & \\
\hline Radiation & & 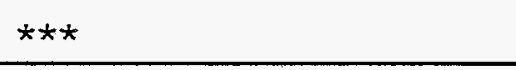 \\
\hline \multicolumn{3}{|l|}{ Settling Velocity } \\
\hline \multirow[t]{4}{*}{ Shear Strength } & \multirow[t]{2}{*}{ Shear Vàne } & $\begin{array}{l}\text { Abdelhamid, M.S. et al. } \\
\text { Heath, W.0. }\end{array}$ \\
\hline & & $\begin{array}{l}\text { Ervin, M. C., (Walker, } \\
\text { B.F.) }\end{array}$ \\
\hline & $\begin{array}{l}\text { Standard Penetration } \\
\text { Test }\end{array}$ & $\begin{array}{l}\text { Ervin, M. C., (Douglas, } \\
\text { D.J.) }\end{array}$ \\
\hline & Pressuremeter & Ervin, M. C., \\
\hline \multicolumn{3}{|l|}{ Shear Wave Velocity } \\
\hline \multicolumn{3}{|l|}{ Tensile Strength } \\
\hline Temperature & & $* \star *$ \\
\hline Viscosity & Shear Vane & Heath, w.0. \\
\hline Viscoelasticity & & \\
\hline
\end{tabular}

*** Techologies are well known at the Hanford Site. 
WHC-SD-TD-RPT-011

Revision 0

Table 9.2. Possible Methods That Can Be Used For Tank Waste Penetration Device.

\begin{tabular}{|l|l|l|}
\hline & Method & Reference \\
\hline $\begin{array}{l}\text { Depth Penetration } \\
\text { Device }\end{array}$ & Waterjet & Quest Integrated, Inc. \\
\hline
\end{tabular}

The search described in this report did not cover other sources of information as:

- Magazines

- Companies' internal documents, application notes, etc...

- Standard measurements from the American Standard for Testing and Measurement (ASTM)

- Standard handbooks

- Proprietary unpublished methods from outside companies

- Related disciplines such as Soil Engineering, Mechanical Engineering, Civil Engineering, etc...

\subsection{REFERENCES}

Abdelhamid, M.S., 1983, In Situ Characterization of the High-Level Waste Sludge at West Valley, Nuclear Waste Management (Proceedings of the Second International Symposium), pp. 124-131.

Bhatia, P. K., 1993, Retrieval Technologies Characterization Data Needs, WHC-SD-WM-RD-039, Westinghouse Hanford Company, Rich7 and.

Boisde G. and Perez J. J., 1987, Miniature Chemical Optical Fiber Sensors for pH Measurements, SPIE Fiber Optic Sensors II, Vol. 798, pp. 238-245.

Ervin, M. C., 1983, In Situ Testing for Geotechnical Investigations, Proceedings of an Extension Course On In Situ Testing for Geotechnical Investigations, Sydney, May-June, pp. 21-31 (Douglas, D. J., The Standard Penetration Test).

Ervin, M. C., 1983, In Situ Testing for Geotechnical Investigations, Proceedings of an Extension Course on In Situ. Testing for Geotechnical Investigations, Sydney, May-June, pp. 33-48 (Sutcliffe, G. and Waterton, C., Quasi-static Penetration Testing). 
WHC-SD-TD-RPT-011.

Revision 0

Ervin, M. C., 1983, In Situ Testing for Geotechnical Investigations, Proceedings of an Extension Course On In Situ Testing for Geotechnical Investigations, Sydney, May-June, pp. 49-64 (The Pressuremeter in Geotechnical Investigations).

Ervin, M. C., 1983, In Situ Testing for Geotechnical Investigations, Proceedings of an Extension Course On In Situ Testing for Geotechnical Investigations, Sydney, May-June, pp. 65-86 (Walker, B. F., Vane Shear Strength Testing).

Galaj Instruments, Inc. 577 Main Street, Islip, New York, 11751.

Heath, W.0., 1987, Development of an In Situ Method to Define the Rheological Properties of Slurries and Sludges Stored in Underground Tanks, PNL-6083/UC-70, Pacific Northwest Laboratory, Rich1and.

Javandel, I., 1989, On the Field Determination of Effective Porosity, LBL--27525, Earth Sciences Division, Lawrence Berkeley Laboratory, Berkekey, Cal ifornia.

Kreider, K.G., Tarlov, M.J., Huang, P.H., 1991, Assessment of Uncertainties in Measurement of $\mathrm{pH}$ in Hostile Environments Characteristic of Nuclear Repositories, NUREG/CR-5711, National Institute of Standards and Technology, U.S. Department of Commerce.

Nguyen, Q. H., 1994, Tank Waste Physical Properties Prioritization Procedures and Resu7ts, WHC-SD-TD-RPT-009, Rev 0, Westinghouse Hanford Company, Richland.

Nguyen, Q. H., 1994, Summary of Tank Waste Physical Properties at the Hanford Site, WHC-EP-0756, Westinghouse Hanford Company, Richland.

Quest Integrated, Inc., 21414 68th Avenue South, Kent, Washington 98032. 
APPENDIX A.

PHYSICAL PARAMETERS

Physical parameters needed for the designing of the retrieval equipment.

\begin{tabular}{|c|c|c|}
\hline $\begin{array}{l}\text { Physical } \\
\text { Property }\end{array}$ & Unit & Description \\
\hline Abrasiveness & . & $\begin{array}{l}\text { The quality or characteristic of being able to } \\
\text { scratch, abrade, or wear away another } \\
\text { material. The property of a material causing } \\
\text { wear of a surface by friction. Miller number } \\
\text { is one measure of abrasiveness. }\end{array}$ \\
\hline $\begin{array}{l}\text { Compressive } \\
\text { Strength }\end{array}$ & $\mathrm{Pa}$ & $\begin{array}{l}\text { The maximum compressive stress (a stress which } \\
\text { causes an elastic body to shorten in the } \\
\text { direction of the applied force) a material can } \\
\text { withstand without failure. }\end{array}$ \\
\hline Corrosiveness & & $\begin{array}{l}\text { Gradual destruction of metal or alloy due to } \\
\text { chemical processes such as oxidation or the } \\
\text { action of a chemical agent. }\end{array}$ \\
\hline Density & $\mathrm{g} / \mathrm{cm}^{3}$ & The mass of a given substance per unit volume. \\
\hline Porosity & Percent & $\begin{array}{l}\text { The ratio of the volume of air or void } \\
\text { contained within the boundaries of material to } \\
\text { the total volume expressed as a percentage. } \\
\text { Porosity }=(\text { Voids Vol } \times 100) / \text { Total Vol. }\end{array}$ \\
\hline Particle Size & micron & $\begin{array}{l}\text { The basic physical unit of the waste particle } \\
\text { after water dissolution. }\end{array}$ \\
\hline Particle Shape & & $\begin{array}{l}\text { The form of the basic unit particle (e.g., } \\
\text { surface area to volume ratio of a particle). }\end{array}$ \\
\hline Radiation & R/hour & $\begin{array}{l}\text { The total amount of ionizing radiation } \\
\text { absorbed by material or tissue, in the sense } \\
\text { of absorbed dose (expressed in rads), exposure } \\
\text { dose (expressed in roentgens), or equivalent } \\
\text { (expressed in rems). }\end{array}$ \\
\hline Shear Strength & $\begin{array}{l}\text { Pascal } \\
(\mathrm{Pa})\end{array}$ & $\begin{array}{l}\text { The maximum shear stress which a material can } \\
\text { withstand without rupture. The ability of } \\
\text { material to withstand shear stress. }\end{array}$ \\
\hline $\begin{array}{l}\text { Shear Waye } \\
\text { Velocity }\end{array}$ & $\mathrm{m} / \mathrm{s}$ & $\begin{array}{l}\text { A wave that causes an element of an elastic } \\
\text { medium to change its shape without changing } \\
\text { its volume. Also known as rotational wave. }\end{array}$ \\
\hline
\end{tabular}

1 Potentially needed property. 
WHC-SD-TD-RPT-011

Revision 0

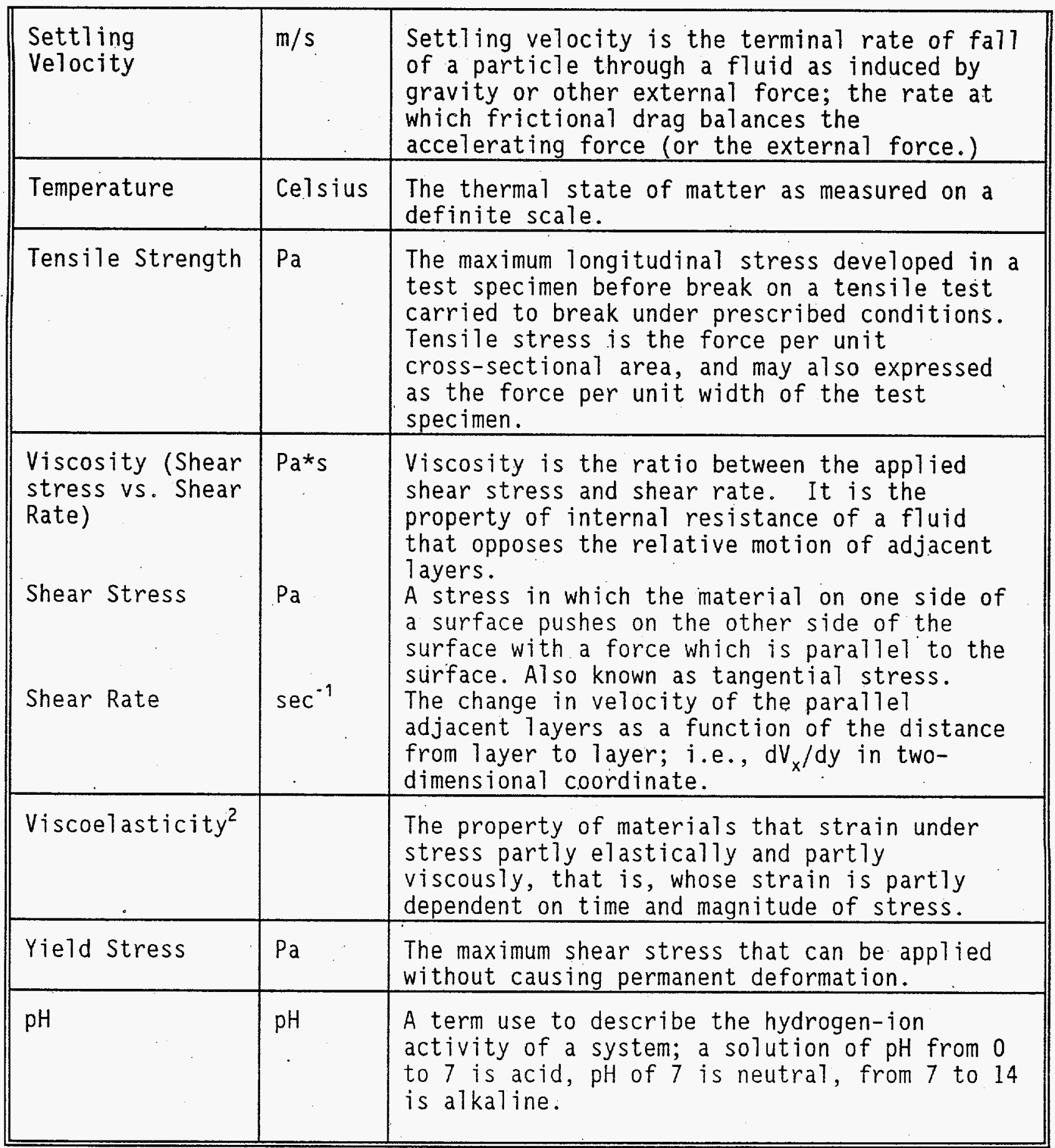

${ }^{2}$ Potentially needed property. 
WHC-SD-TD-RPT-011

Revision 0

\title{
APPENDIX B. DATABASE NAMES AND DESCRIPTIONS
}

\begin{abstract}
Names and descriptions of seven databases that were used in the "Literature Search" category.
\end{abstract}

\section{ENERGY SCIENCE AND TECHNOLOGY}

ENERGY SCIENCE AND TECHNOLOGY (formerly DOE ENERGY), the database of the U.S. Department of Energy, is one of the world's largest sources of literature references on all aspects of energy and related topics. The database provides coverage of journal articles, report literature, conference papers, books, patents, dissertations, and translations. The following energy topics are included: nuclear, wind, fossil, geothermal, tidal, and solar. Related topics such as environment, energy policy, and conservation are also included.

\section{Ei COMPENDEX PLUS}

The Ei COMPENDEX*PLUS ${ }^{T M}$ database provides abstracted information from the world's significant literature of engineering and technology. Ei COMPENDEX PLUS provides worldwide coverage of approximately 4,500 journals and selected government reports and books. Subjected covered include: civil, energy, environmental, geological, and biological engineering; electrical, electronics, and control engineering; chemical, mining, metals, and fuel engineering; mechanical, automotive, nuclear, and aerospace engineering; and computers, robotics, and industrial robots.

\section{INSPEC}

INSPEC (The Database for Physics, Electronics and Computing) corresponds to the three Science Abstracts print publications: Physics Abstracts, Electrical and Electronics Abstracts, and Computer and Control Abstracts.

\section{NTIS}

The NTIS database provides access to the results of U.S. governmentsponsored research, development, and engineering, plus analyses prepared by deferral agencies, their contractors, or grantees. It is the means through which unclassified, publicly available, unlimited distribution reports are made available for sale from agencies such as NASA, DDC, DOE, HUD, DOT, Department of Commerce, and some 600 other agencies. In addition, some state and local government agencies now contribute their reports to the database.

NTIS also provides access to the results of government-sponsored research and development from countries outside the U.S. Organizations that currently contribute to the NTIS database include: the Japan Ministry of International Trade and Industry (MITI); Taboratories administered by the United Kingdom 
Department of Industry; the German Federal Ministry of Research and Technology (BMFT); the French National Center for Scientific Research (CNRS); and many more.

\section{PASCAL}

PASCAL is a multidisciplinary database equivalent to the 79 print Pascal journals. Major subjects covered include: life sciences, biology, and medicine; chemistry, applied chemistry, and pollution; energy; metallurgy, mechanical and civil engineering; transportation; food and agricultural sciences; earth sciences; physics and space sciences; and computer sciences and engineering.

\section{SCISEARCH}

SCISEARCH ${ }^{\infty}$ a multidisciplinary index to the literature of science and technology. Prepared by the Institute for Scientific Information (ISI), it contains all records published in Science Citation Index (SCI ${ }^{*}$ ) and additional records from the Current Contents series of publications that are not included in the print version of SCI. SCISEARCH is distinguished by two important and unique characteristics. First, journals indexed are carefully selected on the basis of several criteria, including citation analysis, resulting in the inclusion of 90 percent of the world's significant scientific and technical. literature. Second, citation indexing is provide, which allows retrieval of newly published articles through the subject relationships established by an author's reference to prior articles. SCISEARCH covers every area of the pure and applied sciences.

\section{SPIN}

SPIN $^{\otimes}$ (Searchable Physical Information Notices) is designed to provide the most current indexing and abstracting of a selected set of the world's most significant physical journals. SPIN covers all major area of physics, including mathematical and statistical physics, astronomy, astrophysics, and geophysics. 
WHC-SD-TD-RPT-011

Revision 0

\section{APPENDIX C. \\ WORLDWIDE LITERATURE SEARCH LOG}

This appendix includes the summary of the steps that were used to perform worldwide literature search at the Battelle Pacific Northwest Library, Richland, Washington. Databases used are INSPEC, NTIS, Ei COMPENDEX PLUS, ENERGY SCIENCE AND TECHNOLOGY, PASCAL, and SCISEARCH. The term "s" represents "set", a temporary storage place to save intermediate search records.

Search No 1 strategy:

Comments

s1 : (radioactive or nuclear)(2n)waste? ?

s2 : physical()property???

s3 : measur? or detect? or method? or technique? ?

s4 : s1 and $s 2$ and $s 3$

s5 : $s 4 / E N G$

s6 : rd

Total 1011 Unique records

English only Remove Duplication

\section{Search No 2 strategy:}

s1 : physical()propert???

s2 : (radioactive or nuclear) (2n)waste? ?

s3 : s1 and s2

s4 : s3 and (sensor? ? or instrument? ? or device? ?)

s5 : $s 4$ not (method? or measur?)

s6 : s2 and (shear()(stress or strength or rate or wave))

s7 : s2 and (yield()strength or viscosit??? or viscoelastic)

s8 : s2 and (abrasiv? or corrosiv? or permeab? or density or temperature? ?)

s9 : s2 and (ph or ((compressive or tensile)()strength) or porosity or rheology)

s10: $s 6: s 9$

s11: s10 and (measur? or method?)

s12: shear()(stress or strength or properties or wave or rate)

s13: $s 12 / t i$, de

s14: yield()strength or viscosit???/ti,de or viscoelastic

s15: (abrasiv? or permeab? or density or temperature? ?)/ti, de

s16: $s 13$ and s2

s17: (s14 or s15) and s2

s18: $\mathrm{pH} / \mathrm{ti}$, de or (compressive or compression()strength)/ti, de

s19: tensile()(strength or properties)/ti,de or corrosiv?

s20: porosity/ti,de or rheology/ti,de

s21: (s18:s20) and s2

s22: $\$ 16$ or $\$ 17$ or $\$ 21$

s23: 522 and (measur? or method?)

s24: S22 and (detect? or technique? ?)

s25: S22 and (sensor? ? or instrument? ? or device? ?)

s26: S22 and (measur?/ti,de or method?/ti,de)

s27: s22 and (detect?/ti,de or technique? ?/ti,de) 
WHC-SD-TD-RPT-011

Revision 0

s28: $s 25$ or $s 26$ or $s 27$

s29: s28/ENG

s30: s29 not (physical()propert???)

s31: $r d$

s32: $s 5$ or $s 31$

s33: s32/1983: 1993

Total 1026 Unique records 
WHC-SD-TD-RPT-011

Revision 0

\section{APPENDIX D. \\ WORLDWIDE LITERATURE SEARCH RESULTS}

This appendix lists the search results from the worldwide literature search. The complete hard copy is not included in this report but it can be found in ???. Only titles from the records found are listed here for completeness.

\section{SEARCH NO 1: GENERAL PHYSICAL PROPERTY}

Hanford Technical Library

Database Search Service

11/29/93 10:12am

\section{Record Title}

1

2

Analytical Chemistry Laboratory ( $A C L$ ) procedure compendium

LBL/GRP studies of fractured rocks: Summary FY 1986--1990

Earth Sciences Division annual report 1988

Chemical Technology Division, Annual technical report, 1991

Earth Sciences Division. annual report, 1987

Resource Conservation and Recovery Act, Part B permit application

Argonne National Laboratory Research Highlights 1988

Chemical Technology Division annual technical report, 1988

Thermochemistry of minerals stable near the earth's surface

Plutonium helps probe protein, superconductor

Grimsel test site. Overview and test programs

Repository design sensitivity study: Engineering study report TI <Augmentation> Contains glossary

13 B B ock Test Step 1 report

Chemical technology division: Annual technical report 1987

Thermal conductivity probe test procedure: Final draft

16 Treatment of low- and intermediate-level liquid radioactive wastes TI <Series/Collective> Technical reports series

17 INTRACOIN. Final report levels 2 and 3 . Model validation and uncertainty analysis

18 Geochemistry TI Earth Sciences Division annual report, 1982

19 Scientific investigations of radioactive waste disposal in salt at WIPP TI Sandia Technology. Volume 9, No. 1

20 Feasibility study for the design of a simulated radioactive waste repository facility. Volume 2 - figures - tables

21 Donald C. Cook Nuclear Power, Unit 1. Environmental operating report: July--December 1976

22 I Nevada Nuclear Waste Storage Investigations Project. Quarterly report, Apri1-June 1985

23 Nukleonika. Volume 14, Number 4, 1969

24 Chemistry of transuranium elements and compounds TI Chemistry Division annual progress report for period ending January 31, 1985

Finite-length Tine source superposition model (FLLSSM) 
WHC-SD-TD-RPT-011

Revision 0

27 Oceanographic model for the dispersion of wastes disposed of in the deep sea

28 Disposal of spent nuclear fuel

29 Report of laboratory testing on rock core samples, Mansfield No. 1 (PD-4) we 11, Palo Duro Basin, Texas: unanalyzed data

30 Results of repository conditions study for commercial and defense high-level. nuclear waste and spent fuel repositories in salt

31 Admissible thermal loading in geological formations. Consequences on radioactive waste disposal methods. Vol. 1.

32 Study of chemical toxicity of low-level wastes. Volume 2. Monographs

33 Study of chemical toxicity of low-level wastes. Volume 1. Main report Repository TI Technical progress report, 1 Apri1-30 June 1981

35 Uranium Hexafluoride: Handling Procedures and Container Descriptions

36 Basic data report for drillhole ERDA 9 (Waste Isolation Pilot Plant WIPP)

37 Basic data report for drillhole WIPP 15 (Waste Isolation Pilot Plant-WIPP)

38 Solidification of high level wastes. Part III. Solubility, melting point, flow temperature and thermal conductivity of some calcined, synthetic purex-type wastes

39 Borehole plugging telemetry system. Technical report Characteristics of solidified high-level waste products

Thermal/mechanical properties of Pomona and Umtanum basalts: elevated temperature comparative triaxial test

42. I Basic data report for drilihole WIPP 30 (Waste Isolation Pilot Plant WIPP)

43 i Resource Conservation and Recovery Act, Part B permit application. Volume 3

44 I Subseded disposal program annual report, January-December 1978. Volume II. Principal investigator progress reports

45 Millstone Nuclear Power Station, Units 1 and 2. State of Connecticut, Dept. of Environmental Protection NPDES permit

46 I Publications of the Physikalisch-Technische Bundesanstalt Compiled by Referat Schrifttum

47 Below Regulatory Concern Owners Group: nonradiologic characterization and environmental assessment of BRC waste

48 <English> Underground disposal of radioactive wastes. Basic guidance

49 Analysis of Annual Mean and Collective Doses of Occupational Exposure of Personnet in KFTI AN USSR (Akademiya Nauk USRS, Kharkov.

Fiziko-Tekhnicheskii Inst.)

50 I Study of the Possibilities of Radioactive Waste Storage in Crystalline Formations. Investigation by Deep Drilling of the Auriat Granite

51 Evaluation of radon emissions and potential control requirements: For the Weldon Spring Site Remedial Action Project, Weldon Spring, Missouri

52 Laboratory testing of rock and salt samples for determination of specific gravity and total porosity of the Zeeck No. 1 well (PD-7), Palo Duro Basin, Texas: unanalyzed data

53 Laboratory testing of rock and salt samples for determination of specific gravity and total porosity of the Mansfield No. I Well (PD-4), Palo Duro Basin, Texas: unanalyzed data 
WHC-SD-TD-RPT-011

Revision 0

National waste terminal storage repository in a bedded salt formation for spent unreprocessed fuel. Special study No. 3. Waste retrieval from backfilled regions

Disposal of radioactive waste into geological formations: studies on crystalline rock

Development and characterization of cermet forms for radioactive waste

In situ characterization of the high-level waste sludge at West Valley Nuclear waste management TI <Series/Collective> Advances in ceramics, vol. 8

Elastic and strength properties of Hanford concrete mixes at room and elevated temperatures

59 | Fluid-bed process for Synroc production Nuclear waste management TI <Series/Collective> Advances in ceramics, vol. 8

60 Thermal conductivity of S.E. New Mexico rocksalt and anhydrite TI <Augmentation> Saltcrete

61 Geo-engineering review and proposed.program out ine for the structural design of a radioactive waste repository in Columbia Plateau basalts

62. Hydrochemical investigations at Finnsjoen, Sweden Characterization of fracture zone 2, Finnsjoen study-site

63 Non-destructive determination of / sup $239 / \mathrm{Pu}$ in wastes by application of . gamma..-ray measurement

64 Magnetic susceptibility of sodium disilicate glasses containing Pu0/sub 2/ TI <Augmentation> 4 to $300 /$ sup $0 / \mathrm{K}$

65 In situ containment and stabilization of buried waste. Annual report FY 1992 TI <NOTE> Progress rept

Radiant-heat spray calcination studies

Experimental studies of packing material stability

Heat transfer analysis of the geologic disposal of spent fuel and high-level waste storage canisters

9 I Startup of a Joule-heated glass melter with a graphite slurry Nuclear waste management TI <Series/Collective> Advances in ceramics, vol. 8

70 | Hydraulic testing in crystalline rock. A comparative study of single-hole test methods

71 Palaeomagnetism of major rock units surrounding the Vaalputs National Radioactive Waste Disposal Site

72 Rock property analys is of core samples from the Yucca Mountain UE25a-1 borehole, Nevada Test Site, Nevada TI <Augmentation> NNWSI project

73 Rock property analysis of core samples from the Cal ico Hills UE25a-3 borehole, Nevada Test Site, Nevada TI <Augmentation> NNWSI project

74 i Rock property measurements on large-volume core samples from Yucca Mountain USW GU-3/G-3 and USW G-4 boreholes, Nevada. Test Site, Nevada

75 Development of test methods for quality control of $L L W$ and MLW in cement or polymers (Parts 1 and 2). Task 3. Characterization of radioactive waste forms. A series of final reports (1985-1989) no. 39 PAPERS PRESENTED AT ACTINIDES 85.

77 Volume calibration and instrument testing at ENEA (Italian Commission for Alternative Energy Sources) central research Taboratory (Casaccia, Italy)

78 Iron-nickel alloys as canister material for radioactive waste disposal in underground repositories Earth Sciences Division annual report 1981 
79. Theoretical and experimental evaluation of waste transport in selected rocks: 1977 annual report of LBL Contract No. 45901AK. Waste Isolation Safety Assessment Program: collection and generation of transport data

80 I Structural thermodynamic model for the durability and viscosity of nuclear waste glasses

81 Preliminary research on geological isolation of high-ievel radioactive waste at the Japan Atomic Energy Research Institute Underground disposal of radioactive wastes. Proceedings of a symposium jointly organized by the IAEA and the OECD NEA and held at Otaniemi, Finland, 2-6 July 1979

82 Pretest 3D finite element analysis of the WIPP Intermediate Scale Borehole Test

83 I Radiation hardening of rocksalt

84 Ion implantation effects in alkali-borosilicate glasses

85 Ion implantation effects in glasses

86 Thermochemical properties of SrSiO(g) and SrBo sub 2 (g) (in relation to radioactive waste disposal)

87 Vaporisation of sodium-rubidium borosilicate glasses

88 Mapping and monitoring nuclear waste repositories with subsurface electrical resistivity arrays Proceedings of the 57 th annual international SEG meeting: Expanded abstracts with biographies

89 Measurement methods for thermal transport properties of rocks Research and engineering applications in rock masses. Volume 2.

Metal compacts for high-level radioactive wastes fixation Solidification of high-level radioactive wastes by metal matrix The Mirage Project: Actinide and fission product physico-chemical behaviour in geological environment Radioactive waste management and disposal

93 Above-ground storage facilities for vitrified highly active wastes

94 Study of the Boom clay layer as a geochemical barrier for long-lived radionuclides High-level nuclear waste disposal

95 106-AN grout pilot-scale test HGTP-93-0501-02

96 Analysis of hydraulic gradients across the host rock at the proposed Texas Panhandle nuclear-waste repository site

97 Flow directions and hydraulic gradients in the variable density flow system at the proposed high-level nuclear waste repository site in the Texas panhandle

98 . Constitutive properties and material model development for marine sediments in support of the subseabed disposal program Subseabed disposal program annual report, January-December 1980 . Volume II. Appendices (principal investigator progress reports). Part 1

99 Faults in clays their detection and properties

100 Magnetic properties of drill core and surface samples from the calico Hills area, Nye County, Nevada

101 A methodology to define the flow rate and pressure requirements for transfer of double-shell tank waste slurries

102 Seismic design and evaluation guidelines for the Department of Energy high-level waste storage tanks and appurtenances

103 Leaching of saltstones containing fly ash

104 High-temperature vitrification of Hanford residual-1iquid waste in a continuous melter

105 Geochemical behavior of disposed radioactive waste 
WHC-SD-TD-RPT-011

Revision 0

106

Solidification of High Level Wastes. Part V. A Factorial Study of the Effect of Varying the Concentration of the Components of Purex Type Waste on the Properties of Phosphate Solids. Appendix. Response Surface Statistical Analysis

107 i The modelling and measurement of super-conducting rock joints Research and engineering applications in rock masses. Volume 1

108 Method for field determinations of the chemical and physical characteristics of radionuclides after release into the river water Radiation - risk - protection. Vol. 2

109 Rock properties input to the site screening process

110 Chemical aspects governing the choice of backfill materials for nuclear waste repositories

111 Interpretation of hydraulic testing in the sediments of the Riniken borehole

112 Interpretation of hydraulic testing in crystalline rock at the Leuggern borehole

113 The effects of petroleum coke properties on carbon anode quality

114

115 242-A Evaporator/Crystallizer flowsheet

Recommendations to the NRC for soil cover systems over uranium mill tailings and low-level radioactive wastes

116

117 Tabulation and evaluation of ion exchange data on smectites, certain

Hanford site Grout Treatment Facility. zeolites and basalt

118 Thermal analysis of the WIPP in situ Room AI DHLW package experiments

119 Numerical thermal modeling of the WIPP in situ room A1 simulated DHLW experiments Waste management 187: Waste isolation in the US, technical programs, and public education TI <Series/Collective> Volume 2 - High-level waste

120 A thermodynamic description of the evolution of pore water chemistry and uranium speciation during the degradation of cement

121 Impacts to nuclear utilities of 10CFR61 Waste isolation in the U.S., technical programs and public education. Vol. 2

122 Effects of alpha, gamma, and alpha-recoil radiation on borosilicate glass containing Savannah River Plant defense high-level nuclear waste TI <Augmentation> Lead ions-250 keV^ xenon ions-160 keV

123 Control of high-level radioactive waste-glass melters

124 Control of high-level radioactive waste-glass melters. Part 4, Preliminary analysis of DWPF process laboratory capabilities

125 The role of colloids in the transport of radionuclides in geological formations

126 Critical parameters for a high-level waste repository: Volume 2, Tuff

127 Critical parameters for a high-level waste repository: Volume 3, Salt

128 Critical parameters for a high-level waste repository. Volume 1. Basalt

129 Trials and control of placing and sealing materials for deposits in scale models Sealing of Radioactive Waste Repositories

130 Effects of long-term exposure of tuffs to high-level nuclear waste-repository conditions. Preliminary report

131 Inservice inspection of double-shell storage tanks at the Hanford Site

132 Results of a multiple borehole pumping test in low permeability

granite Low flow, low-permeability measurements in largely impermeable rocks 
WHC-SD-TD-RPT-011

Revision 0

133 Rapid estimation of the regional thermal response to a nuclear waste repository-limiting case analysis

134 Application of integral methods to prediction of heat transfer from a nuclear waste repository

135 Rock mechanics methods and in situ heater tests for design of a nuclear waste repository in basalt

136 Laboratory determination of the mechanical, ultrasonic and hydrologic properties of welded tuff from the Grouse Canyon heated block site: Nevada Nuclear Waste Storage Investigations Project TI <Augmentation> NNWS I

137 Determination of the thermal properties of clays in large-size samples

138 Site Characterization Data for Solid Waste Storage Area 6

139 Characterization plan for Sol id Waste Storage Area 6

140

141 Laboratory testing and computer simulation of clay barrier behaviour Permeability of the multilayer overburden system at the Weldon Spring site Proceedings of the geosciences workshop. Weldon Spring Site Remedial Action Project

142 Storage and solidification of MAW/LAW in underground caverns. Second semiannual report 1979

143 Study of the Penetration of Projectiles into Marine Sediments

144 Statistical tests applied as quality control measures to leaching of nuclear waste glasses and in the evaluation of the leach vessel

145 I Melting process to condition decladding hulls generated by the reprocessing of LWR and FBR spent fuels Scientific basis for nuclear waste management. Volume 3

146 i Cross borehole electromagnetic imaging of chemical and mixed waste landfills

147 Interim report on excavation effect studies at the waste isolation pilot plant: the delineation of the disturbed rock zone Excavation response in geological repositories for radioactive waste Proceedings of an. NEA Workshop

148 Induced polarisation and the assessment of sorption/diffusion at radioactive waste repository sites

149 Crystallization of nuclear waste disposal glass

150 Measurement of the specific resistance of vitrified highly-active waste

151 Thermal effects in disposal of radioactive waste in hard rock Experiences de degagement de chaleur in situ dans les formations geologigues

152 i Determination of the $\mathrm{C} i$ content of packaged radioactive waste using measured dose rates

153 Destruction of DOE/DP surrogate wastes with supercritical water oxidation technology

154 A thermomechanical analysis of WIPP (Waste Isolation Pilot Plant) DHLW (Defense High Level Waste) experiments: Waste container/borehole interactions

155

156 Second reference calculation for the WIPP

$\mathrm{RF} /$ microwave volume-reduction and stabilization system for radwaste resins Waste management 86. Volume 3: Low level waste

157 The response of the aerodynamic particle sizer to nonspherical particles and use in experimental determination of dynamic shape factor 
WHC-SD-TD-RPT-011

Revision 0

158

159

160

161

162

163

64

165

166

167

168

169

170

171

172

173

174

175

176

177

178

179

180

181

182

183

Development of waste unit for use in shallow land burial

Measurement of radionuclides in waste packages

Short description of hocus cruise and conclusion HOCUS cruise report Evaluation of geophysical borehole studies

Experiences in the evaluation of fully active waste products

Radioactive waste management. Proceedings of the conference organized

by the British Nuclear Energy Society, London, 27-29 November 1984

Prediction of formation constants for actinide complexes in solution

Soil density and mass attenuation coefficients for use in shielding calculations at the Hanford Waste Vitrification Plant

Determination of the solubility of amorphous $\mathrm{UO2}(\mathrm{s})$ and the mononuclear hydrolysis constants of uranium(IV) at $25 \backslash C$ Scientific basis for Nuclear Waste Management $X$

High-level waste vitrification product characterization Scientific basis for nuclear waste management

Solubilities and speciation of radionuclides in brines: Technical program plan, Fiscal years 1988, 1989: Revised

Characterization of several plasters and one retarder for repository sealing mixtures. Final report

Characterization of Several Plasters and One Retarder for Repository Sealing Mixtures TI <NOTE> Final rept.

Design of a hot pilot plant facility for demonstration of the pot calcination process TI <Series/Collective> IAEA Preprint No. SM-31/18

Pretest thermal analysis of the Tuff Water Migration/In-Situ Heater Experiment

Disposal of toxic waste

Full-scale borehole sealing test in salt under simulated downhole conditions. Volume $1 \mathrm{TI}$ <Augmentation> Avery Island diapiric salt

Calculation of the $5 \mathrm{~kW}$ full scale heater test at Stripa with temperature dependent thermal conductivity and expansion coefficient TI <Augmentation> Thermal loading effects from waste repository Thermomechanical modeling of the spent fuel test - Climax Rock mechanics:Key to energy production

Interdependence of phase chemistry, microstructure, and oxygen fugacity in titanate nuclear waste ceramics

Seismic stability analysis of disposal cells on the Uranium Mill Tailings Remedial Action Project Proceedings of the geosciences

workshop. Weldon Spring Site Remedial Action Project
Application of finite difference techniques to the thermal analysis of

the cooling of a slag casting
Immobilization of Savannah River high-level wastes in SYNROC: results from performance tests

Properties of SYNROC-D nuclear waste form: a state-of-the-art reivew

Transport in unsaturated flow systems using centrifuge techniques Proceedings of the DOE/Yucca Mountain Site Characterization Project Radionuclide Adsorption Workshop at Los Alamos National Laboratory, September 11--12, 1990

Characterization of a borosilicate glass incorporating MTR HLW with reference to the underground disposal Spectrum '86: Proceedings:

Volume 1

Pilot heater test in the Stripa granite 
WHC-SD-TD-RPT-011

Revision 0

184 Action plan for response to abnormal conditions in Hanford site radioactive waste tanks containing ferrocyanide

185 i Hydraulic and thermal properties of soil samples from the buried waste test facility

186 Method and apparatus for obtaining mechanical energy from low temperature heat sources TI <Augmentation> Patent

187 Relationships Between Properties of Hanford Area Soils and the Availability of exp $134 \mathrm{Cs}$ and exp $85 \mathrm{Sr}$ for Uptake by Cheatgrass and Tumbleweed

188 i Relationships between properties of Hanford area soils and the availability of / sup $134 / \mathrm{Cs}$ and / sup $85 / \mathrm{Sr}$ for uptake by cheatgrass and tumbleweed

189' Near-field high-temperature transport: Evidence from the genesis of the Osamu Utsumi uranium mine, Pocos de Caldas alkaline complex, . Brazil

190 Potential industrial applications of calixarenes New separation chemistry techniques for radioactive waste and other specific applications

191 I Physical characterization of radioactive sludges in selected Melton Valley and evaporator facility storage tanks

192 I Selection and evaluation of potential very low level wastes (VLLW) from nuclear power plants Waste Management 185: Waste Isolation in the US - Technical Programs and Public Education. Volume 2. Waste policies and programs, low-level waste

193 Calculated thermally induced displacements and stresses for heater experiments at Stripa, Sweden. Linear thermoelastic models using constant material properties

194 I Rock properties and their effect on thermally-induced displacements and stresses

195 i Predicted and measured temperatures, displacements and stresses from the Stripa heater experiments

196 Heat transfer in underground heating experiments in granite, Stipa, Sweden

197 I Thermomechanical modeling and data analysis for heating experiments at Stripa, Sweden

198 Feasibility studies for a radioactive waste repository in a deep clay formation

199 I Redox calcination study of Synroc D powder containing simulated SRL waste

200 Experiment and analysis comparison in support of the Yucca Mountain Project

201 I Analysis of two radioactive nepheline syenite glass hemispheres retrieved from the Chalk River Nuclear Laboratories' waste management site Radioelement analysis: progress and problems

202 i Nuclear fuel waste management program geotechnical studies of Eye-Dashwa lakes research area rock properties TI <NOTE> Report no. MRL 92-065(TR)

203 i Nuclear fuel waste management program geotechnical studies of Eye-Dashwa Lakes Research Area rock properties. Report No. MRL 92-065(TR)

204 Progress Report on French Research and Development in the Treatment of off-Gases from Reprocessing Plants 
WHC-SD-TD-RPT-011

Revision 0

205 Factors influencing mass diffusion in bentonite and mixtures of bentonite and sand Scientific basis for nuclear waste management VII TI <Series/Collective> Materials Research Society symposia proceedings, Volume 26

206 West Valley high-level nuclear waste glass development: a statistically designed mixture study

207 Evaluation of lead-iron-phosphate glass as a high-level waste form

208 Development of a West Valley nuclear waste glass by empirical modeling

209 Statistically designed study of a nuclear waste glass system Scientific basis for nuclear waste management

210 A pelletizing model and its application to radioactive waste treatment

211. Evaluation of cement stability Waste management '85: waste isolation in the US technical programs and public participation. Volume 3. General interest

212 Freeze and restart of the DWPF Scale Glass Melter

213 Thermal effects of electrically conductive deposits in melter

214 Prediction of temperatures in underground storage facilities for heat-generating materials at the Idaho Chemical Processing $\mathrm{P} 1$ ant

215 Experimental and analytical studies of the thermal aspects of deep geologic disposal of commercial nuclear wastes TI <Augmentation> Includes Glossary

216 Heterogeneous Oxidative Degradation in Irradiated Polymers

217 Disposal of low-level radioactive waste using high-calcium fly ash. Final report

218 Properties of radioactive wastes and waste containers. Quarterly progress report; October--December 1976 TI <Augmentation> Urea-formaldehyde^ polymer^ $^{\wedge}$ portland cement

219 | Properties of radioactive wastes and waste containers. Quarterly progress report, January--March 1977

220 Properties of radioactive wastes and waste containers. Progress report No. 5, Apri1--June 1977

221 i Natural analogue study of the distribution of uranium series radionuclides between the colloid and solute phases in the hydrogeological system of the Koongarra uranium deposit N.T., Australia Natural analogues in radioactive waste disposal. Proceedings of a symposium organised by the CEC and held in Brussels, BE, on 28-30 April 1987. <0riginal Series/Collective> Radioactive Waste Management Series

222 Mechanisms and quantitative evaluations of radionuclide fixation in geosphere Natural analogues in radioactive waste disposal. Proceedings of a symposium organised by the CEC and held in Brussels, BE, on 28-30 Aprit 1987 <Original Series/Collective> Radioactive Waste Management Series

223 Studies and researches in the underground laboratory at Pasquasia mine Geomechanics of clays for radioactive waste disposal

224 Diffusion barrier properties of unsaturated paintbrush tuff rubble backfill

225 Advanced oxidation and reduction processes: Closed-loop applications for mixed waste 
WHC-SD-TD-RPT-011

Revision 0

226 Key issues Proceedings of workshop on thermomechanical-hydrochemical modeling for a hardrock waste repository

227 Choice of french clays as engineered barrier components for waste disposal Scientific basis for Nuclear Waste Management $X$

228 i Nuclear waste repository simulation experiments (brine migration), Asse Mine of the Federal of Germany: Quarterly brine migration data report, JuTy-September 1984

229 Supporting document test plan for jointed Block Test No. 1

230 Block Test No. 1 final report: Results from experimental and numerical analyses at elevated temperatures.

231 Heat removal options and temperature predictions for a vault of grouted waste

232 i Research and development related to the Nevada nuclear waste storage investigations. Progress report, January 1-March 31, 1980

233 Temperature distribution in a hypothetical spent nuclear fuel repository in a salt dome

234 Savannah River Site environmental report for 1989

235 Savannah River Site environmental report for 1989. Volume 2, Figures and data tables

236 Temperature distribution in a hypothetical spent nuclear fuel repository in a salt dome

237 Unsaturated zone characterization of the Area 5 Radioactive Waste Management Site

238 Unsaturated zone characterization of the Area 5 Radioactive Waste Management Site. Phase 1, Preliminary laboratory studies for the determination of soil moisture characteristic curves and unsaturated hydraulic conductivities

239 Laboratory-determined transport properties of Berea sandstone

240 High frequency electromagnetic tomography TI <Augmentation> Yucca Mountain Project

241 Analysis and Development of Methods for the Recovery of Degraded Tri-N-Butyl Phosphate (TBP) $30 \% \mathrm{~V} / \mathrm{V}$-Dodecane TI <NOTE> Tese (M.Sc.)

242 Archive fuel characterization: Task 2 and Task 3

243 Comparison of the microstructure of Hanford Type II concrete structures and test specimens

244 Geophysical well-log measurements in three drill holes at Salt Valley, Utah

245 Hole-to-surface resistivity measurements at Salt Valley, Utah

246 Borehole geophysical measurements for Hole UE25a-3, Nevada Test Site, Nuclear Waste Isolation Program

247 Interpretation of geophysical well-log measurements in drill holes UE25a-4, $-5,-6$, and -7 , Yucca Mountain, Nevada Test Site

248 Effects of various tailings covers on radon gas emanation from pyritic uranium tailings Proceedings of the 1987 national symposium on mining, hydrology, sedimentology, and reclamation

249 Geopolymers: Inorganic Polymeric New Materials.

250 Site characterization techniques used at a low-level waste shallow land burial field demonstration facility 
251 Potential for de-regulated disposal of very low level wastes from nuclear power plants Proceedings of the eight annual DOE low-level waste management forum: Technical Session 7, Waste characterization and regulation

252. Site investigation methods used in Canada's nuclear fuel waste management program to determine the hydrogeological conditions of plutonic rock High-level nuclear waste disposal.

253 Characterizing plutonic rock sites for nuclear fuel waste disposal

254 Cross borehole seismic tomography applications to mineral development

255 Effects of hydrostatic pressure on the integrity of concrete. II. Preliminary studies on monolithic blast furnace slag/cement under simulated sea disposal conditions

256 Effects of hydrostatic pressure on the integrity of concrete. 1. Preliminary studies on monolithic concrete under simulated sea-disposal conditions

257 | Creep of ocean sediments resulting from the isolation of radioactive wastes Radioactive wastes and the ocean TI <Series/Collective> Wastes in the ocean. Vol. 3

258 Effects of hydrostatic pressure on the integrity of concrete. Pt. 2. Preliminary studies on monolithic blast furnace slag/cement under simulated sea disposal conditions

259 Evolution of hydrologic systems and brine geochemistry in a deforming salt medium: Data from WIPP brine seeps

260 | Practical aspects of heat transfer in radioactive-waste repository design

261 Characterization of products arising from the incorporation of low and medium level wastes in cement or polymer matrix

262 Effects of long-term exposure to elevated temperature on the mechanical properties of Hanford concrete

263 Development of an in-line grout meter for improved quality control

264 Characterization and thermal conductivities of some samples of Conasauga shale

265 I Thermal aspects of subseabed disposal of high-level radioactive waste Geotechnical engineering of ocean waste disposal

266 Experiments to determine the migration potential for water and contaminants in shallow land-burial facilities: design, emplacement, and preliminary results

267 | The measurement of thermal diffusivity of simulated glass forming nuclear waste melts Advances in materials characterization TI <Series/Collective> Materials Science Research

268 I Physico-Chemical Radioiodine Species in the Exhaust Air of a Pressurized Water Reactor (PWR3)

269 Standard free energy of formation of UMo0/sub 6/ by thermogravimetry

270 STUDY OF THE COMPACTION PROPERTIES OF POTENTIAL CLAY-SAND BUFFER MIXTURES FOR USE IN NUCLEAR FUEL WASTE DISPOSAL.

271 (US Geological Survey research in radioactive waste disposal, fiscal year 1980:) Search for potential (disposal) sites TI <Augmentation> NNWSI

272 (US Geological Survey research in radioactive waste disposal, fiscal year 1981:) Search for potential (disposal) sites TI <Augmentation> NNWSI 
WHC-SD-TD-RPT-011

Revision 0

273 Preparation and Properties of Monomolecular Films for Use as Radioactive Source Mounts TI <NOTE> Final rept

274 Indirect Rock Mass Investigations for Optimizing Borehole Drilling Programs. Volume 3. Ray Optic Geotomography TI <NOTE> Final rept. Sep 78-Mar 83

275 I Fabrication development for high-level nuclear waste containers for the tuff repository. Phase 1 final report TI <NOTE> Progress rept

276 Fabrication development for high-level nuclear waste containers for the tuff repository TI <Augmentation> Yucca Mountain Project

277 Borosilicate glass for the EUREX high-level wastes. Characterization and behaviour Radioactive waste products - suitability for final disposal. Proceedings

278 I Processing, microstructure, leaching, and long-term stability studies related to titanate high-level waste forms

279 I Salt Block I test: experimental details and comparison with theory. Final report

280 Reduction of radioactivity in a nuclear chimney after stimulation of a gas reservoir TI <Augmentation> Patent

281 Thermal properties of rock salt and quartz monzonite to $573 / \mathrm{sup} 0 / \mathrm{K}$ and 50-MPa confining pressure

282 i Thermal properties of rock salt and quartz monzonite to $573 \mathrm{k}$ and 50-mpa confining pressure

283 Thermal conductivity, diffusivity and expansion of Avery Island salt at pressure and temperature

284 Thermal conductivity of Permian Basin embedded salt at elevated pressure Thermal conductivity 18

285 i Thermal conductivity and diffusivity of Permian Basin bedded salt at elevated pressure and temperature

286 Corrosion mechanisms of vitrified high-level waste

287 Computer tomography of barrels with radioactive contents

288 Three-dimensional thermal analysis for the WIPP in situ Test Room A2 heater configuration TI <Augmentation> With simulated radioactive heat source

289 i Status of SHAFT 78 with respect to modeling radioactive waste burial in Eleana argillite, including calculations to date

290 I Some high-temperature properties of simulated West Valley nuclear waste glass Annual meeting abstracts

291 Desublimation of krypton from a noncondensable carrier gas

292 Quarterly brine migration data report, July-September 1985: Nuclear waste repository simulation experiments (brine migration), Asse Mine of the Federal Republic of Germany

293 Experiment simulating the thermal impact of a HLW depository on the surrounding rock formation

294 | The use of magnetic susceptibility and its frequency dependence for delineation of a magnetic stratigraphy in ash-flow tuffs

295 Testing and evaluation of solidified high-level waste forms. Joint annual progress report 1982

296 i Thermal simulation of drift emplacement - evaluation of the backfilling technique Proceedings of the Joint United States/Federal Republic of Germany Technical Exchange Conferences on Nuclear Waste

297. MAGNUM-2D computer code: user's guide 
WHC-SD-TD-RPT-011

Revision 0

298 Electrical service and controls for joule heating of a nuclear waste experimental glass melter Conference record of the Industry

Applications Society IEEE-IAS-1984 annual meeting

299 I Thermal property measurements of Pomona member basalt from core holes DB-5 and DB-15, Hanford site, southeastern Washington

300 I Effect of transport and resistivity characteristics of the environment on the corrosion of steel Proceedings of the Electrochemical Society fall meeting. Volume 88-2 (extended abstracts)

301 i Unsaturated flow and transport through fractured rock related to high-level waste repositories

302 Preliminary studies on fabrication routes for SYNROC

303 Compatibility of Various Polymeric Liner and Pipe Materials with Simulated Double-She11 Slurry Feed at 90C: Hanford Grout Technology Program

304 The compatibility of various polymeric liner and pipe materials with simulated double-she11 slurry feed at 90/degree/C: Hanford Grout Technology Program

305 Crucible melts and bench-scale ISV (in situ vitrification) tests on simulated wastes in INEL (Idaho National Engineering Laboratory) soils

306 Results of temperature test 6 in the Asse salt mine. Volume 1 - Main report

307 Results of temperature test 6 in the Asse salt mine. Volume 2 Appendix

308 Physical and chemical properties of bentonite-loam mixture as backfill materials Low and intermediate level radioactive waste management <Original Series/Collective> Volume 1

309 I Immobilization of tritiated water in synthetic rock Low and intermediate level radioactive waste management <0riginal Series/Collective> Volume 1

310 Design, fabrication and testing of a rock instrumentation system for monitoring the thermal-mechanical response of basalt

311 Final results of thermal conductvivity tests on basalt cores

312 Computation of health risk associated with radionuclide transport and human exposure

313 I Immobilization of IFR salt wastes in mortar Proceedings of the international topical meeting on nuclear and hazardous waste management

314 STingram survey at Yucca Mountain on the Nevada Test Site

315 Concrete encapsulation for spent nuclear fuel storage TI $<$ Augmentation> Patent

316 Iron-rich basalt-type waste forms for transuranic and low-level waste containment: evaluation of electromelt castings

317 I Preliminary permeability and water-retention data for nonwelded and bedded tuff samples, Yucca Mountain area, Nye County, Nevada

318 Hot and cold pressing of (La,Ce)PO/sub 4/-based nuclear waste forms Alternate nuclear waste forms and interactions in geologic media

319 RESISTANCE OF HIGH-LEVEL WASTE MATERIALS TO DISSOLUTION IN AQUEOUS MEDIA.

320 Encapsulation of spent nuclear fuel in ceramic materials. An introductory study 
WHC-SD-TD-RPT-011

Revision 0

321 1/12-scale physical modeling experiments in support of tank 241-SY101 hydrogen mitigation

322 I CCA one-phase conduction convection compaction TI <Augmentation> CDC7600^ FORTRAN IV

323 In-situ grouting of the low-level radioactive waste disposal silos at ORNL's Solid Waste Storage Area Six

324 Solidification of commercial and defense low-level radioactive waste in polyethylene Proceedings of the ninth annual DOE low-level waste management forum: Technical session 6, Waste treatment

325 i Predicting radon flux from uranium mill tailings Management of uranium mill tailings, low-level waste, and hazardous waste

326 HOCUS cruise report: BRE and JRC penetrator experiments HOCUS cruise report

327 Migration of $\mathrm{Pu}$ and Am. Proceedings of an actinide-sediment reactions working meeting

328 Parametric melting studies for in situ vitrification

329 A calculational technique for estimating gamma radiation absorption in low-level waste Waste management 86. Volume 3: Low level waste

330 Use of ceramic materials in waste-package systems for geologic disposal of nuclear wastes

331 Physical Property Measurements on Cesium Chloride and Cesium Chloride--Alkali Metal Chloride Systems

332 Method for calculating the time-dependent surface temperature of a cylinder containing radioactive waste

333 Corrosion reactions of chromium and iron with rubidium-oxygen solutions Liquid metal engineering and technology. 3 Vols.

Proceedings of the 3. international conference held in Oxford on 9-13 April 1984. Vol. 2

334 Cask for radioactive material and method for preventing release of neutrons from radioactive material TI <Augmentation> Patent

335 Boron adsorption on hematite and clinoptilolite TI <Augmentation> Yucca mountain project

336 Stored energy in irradiated salt samples

337 The dissolution of U0/sub 2/: A thermodynamic approach

338 Interaction of Uranium Mill Tailings Leachate with Soils and Clay Liners: Laboratory Analysis/Progress Report TI <NOTE> Technical rept.

339 Characterization of a French clay barrier and outline of the experimental programme.

340 History and geophysical description of hazardous waste disposal Area A: Technical Area 21

341 Performance prediction of mechanical excavators from linear cutter tests on Yucca Mountain welded tuffs. Yucca Mountain Site Characterization Project

342 Performance prediction of mechanical excavators from linear cutter tests on Yucca Mountain welded tuffs

343 Physical properties data for rock salt

344 Evaluation of low and intermediate level radioactive solidified waste forms and packages Evaluation of low and intermediate level radioactive solidified waste forms and packages

345 Radioactive waste from nuclear power plants. 2. Thermal properties of waste/polymer products 
WHC-SD-TD-RPT-011

Revision 0

346 I Diffusion of nonreactive and reactive solutes through fine-grained barrier materials

347 Shale: Measurement of thermal properties

348 Testing protocols for evaluating monolithic waste forms containing mixed waste Nuclear waste management II TI <Series/Collective> Advances im ceramics. Volume 20

349 Impact of High-Level-Radioactive Wastes thermal output on repository design

350 Impact of HLW thermal output on repository design. Proceedings of high level radioactive waste management

351 I Indirect rock. mass investigations for optimizing borehole drilling programs. Volume 1. Executive summary

352 Miller scaling of finger properties in sandy soils: An indirect method for estimating finger width and velocity TI <Augmentation> Yucca Mountain Project

353 Laboratory development of a pot calcination process for converting liquid wastes to solids

354 i Survey on the measurement of thermal conductivity of solids produced by evaporation and calcination of synthetic fuel reprocessing solutions

355 I Sampling and analysis of high level waste tank supernatant: an overview TI <Augmentation> Savannah River Plant

356 Q Qualification and characterization programmes for disposal of a glass product resulting from high level waste vitrification in the PAMELA installation of BELGOPROCESS Geological disposal of spent fuel and high level and alpha bearing wastes TI <Original Series/Collective> Proceedings series

357 I Measurement of the photoneutron yield in the irradiation of heavy materials in closed shells

358

359

High-temperature spectroscopy for nuclear waste applications

360 Radiation damage studies related to nuclear waste forms The electronic and magnetic properties of RPO [sub 4]: TmPO[sub 4] Surveys of research in the Chemistry Division, Argonne National Laboratory

361 i Use of chaotic and random vibrations to generate high frequency test inputs

362. I Preliminary results from the full-scale heater tests at the near-surface test facility 22 nd US symposium on rock mechanics: rock mechanics from research to application

363

Thermal measurements in large pool fires Heat and mass transfer in fire TI <Series/Collective> HTD - Vol. 73

364 Thermal measurements in a series of 1 arge pool fires

365 Role of seed particles in the prediction and control of product particle size in fluidized-bed dryers

366 Determination of plutonium in high-activity solutions Actinides-89

367 Correlation of alluvial deposits at the Nevada Test Site

368 High-level waste solidification: why we chose glass

369 Hydrologic study of the unsaturated zone adjacent to a radioactive-waste disposal site at the Savannah River Plant, Aiken, South Carolina

370 Development of an HLLW melter to large scale industrial application Spectrum '86: Proceedings: Volume 1 
WHC-SD-TD-RPT-0I1

Revision 0

371 Modified cement-based borehole plugging materials: properties and potential longevity Proceedings of the workshop on borehole and shaft plugging, Columbus, 7-9 May 1980

372 Preparation and characterization of an improved high level radioactive waste (HAW) borosilicate glass Scientific basis for nuclear waste management

373 i Characterization of spent fuel hulls and dissolution residues Radioactive waste management and disposal

374 Borehole-plugging-materials development program report 3

375 Borehole-Plugging-Materials Development Program Report 3

376 Survey of matrix materials for solidified radioactive high-level waste

377 Repository site data report for Tuff: Yucca Mountain, Nevada TI <Augmentation> Yucca Mountains

378 Thermophysical properties of deep ocean sediments

379 Nondestructive compressive strength inspection system for cement-solidified waste packages. Proceedings of the international meeting on nuclear and hazardous waste management

380 i Interpretation of geophysical well-log measurements in drill hole UE25a-1, Nevada Test Site, Radioactive Waste Program

381 STATE OF STRESS, PERMEABILITY, AND FRACTURES IN THE PRECAMBRIAN GRANITE OF NORTHERN ILLINOIS.

382 Evaluation of nonradioactive, colored microspheres for measurement of regional myocardial blood flow in dogs

383 i Development and radiation stability of glasses for highly radioactive wastes Management of radioactive wastes from the nuclear fuel cycle. Vol. 2

384 Design criteria for experimental radioactive waste disposal trenches at the Vaalputs radioactive waste disposal facility Radwaste ' $86:$ ' proceedings volume. Conference on the treatment and containment of radioactive waste, and its disposal in arid environments

385 I Chemical decontamination at Carolina Power and Light Company's Brunswick Nuclear Project

386 Drilling and coring methods that minimize the disturbance of cuttings, core, and rock formation in the unsaturated zone, Yucca Mountain, Nevada

387 i Laboratory investigations Proceedings of workshop on thermomechanical-hydrochemical modeling for a hardrock waste repository

388 i Disposal of radioactive liquid wastes from 300 area laboratory facilities

389 Reconsolidation of salt as applied to permanent seals for the Waste Isolation Pilot Plant

390 The physical properties and chemical composition of the gas within the free volume of canistered waste forms

391 Volatility of simulated high-level nuclear waste glass by thermogravimetric analysis

392 Development of a test series to determine in situ thermomechanical and transport properties Measurement of rock properties at elevated pressures and temperatures TI <Series/Collective> ASTM Special

Technical Publication 869

393 i Mass transfer in water-saturated concretes 
WHC-SD-TD-RPT-0.11

Revision 0

394 Thermodynamic properties of geologic materials: status and future Application of geochemical models to high-level nuclear waste repository assessment: conference proceedings

395 i Calculations on heat generation in the storage and solidification of MLW/LLW in 1arge-capacity caverns (Reference systems $A$ and $B$ of the in-situ project)

396 Analysis of geological and geophysical data from study locations C/sub $1 /, \mathrm{B} / \mathrm{sub} 1 /$, and $\mathrm{E} / \mathrm{sub} 2 /$ in the northwest $\mathrm{PAC} 1$ study region Subseabed disposal program annual report, January-September 1981. Volume II. Appendices (principal investigator progress reports). Part 1

397 Application of surface complexation models for radionuclide adsorption 398 Evaluation of electric melter refractories for contact with glass used for the immobilisation of nuclear waste

399 I Variability of an unsaturated sand unit underlying a radioactive-waste trench.

400 Stress, strain, and temperature induced permeability changes in potential repository rocks National waste terminal storage program

401 Permeability of generic repository rocks at simulated in situ conditions Low flow, low-permeability measurements in largely impermeable rocks

402 I R/V Endeavor cruise EN-024. Seabed Disposal Program: North Atlantic study area MPG-III $35 /$ sup $0 / 30^{\prime} \mathrm{N} 61 /$ sup $0 / 00$ 'W, June $30--J u 7 y ~ 11$, 1978. Final report

403 I R/V Endeavor Cruise EN-024. Seabed Disposal Program: North Atlantic Study Area MPG-III $35 \exp 030^{\prime} \mathrm{N} 61 \exp 000^{\prime} \mathrm{W}$, June 30--July 11, 1978. Final Report

404 Test design requirements: Thermal conductivity probe testing

405 Remarks on distributed concepts in environmental data systems 2. Ispra nuclear electronics symposium

406 I Risk methodology for geologic disposal of radioactive waste: asymptotic properties of the environmental transport model

407 Risk methodology for geologic disposal of radioactive waste: sensitivity analysis of the environmental transport model

408 Investigations on the possibility of ultimate storage of radioactive waste in a subterranean argillaceous formation

409 i Thermal simulation of drift emplacement (TSS): In-situ instrumentation and numerical modeling of stress measurement methods Proceedings of the Joint United States/Federal Republic of Germany Technical Exchange Conferences on Nuclear Waste

410 Waste salt recovery, recycle, and destruction

411 Heat transfer and fluid mechanics Subseabed disposal program annual report, January-September 1981. Volume II. Appendices (principal investigator progress reports). Part 1

412 Thermal conductivity measurements of Pacific illite sediment Thermal Response Studies. 1984 Subseabed Disposal Project annual report, October 1983 - September 1984

413 Thermal and fluid analyses Subseabed disposal program annual report, January to December 1979. Volume II. Appendices (principa] investigator progress reports). Part 1 of 2

414 i Numerical modeling of the Near Surface Test Facility No. 1 and No. 2 heater tests 
WHC-SD-TD-RPT-011

Revision 0

Geology of the UE17e dri11 hole, Area 17, Nevada Test Site

416

Mechanical and thermophysical properties of hot-pressed SYNROC B

417

Densification studies of Synroc $D$ for high-level defense waste

418

419

Salt Block II: description and results

Diffusion of iodide in compacted clays

420

Evaluation of asphalt and other materials for lining radiochemical waste storage basins

421. Review of the 1979 workshop on thermomechanical modeling for a hard rock waste repository

422 I Proceedings of a workshop on thermomechanical modeling for a hardrock waste repository

423 - Application and results of a reinjection technique for hydrotherma? experiments in Dickson autoclaves

424 Geophysical methods for fracture characterization in and around potential sites for nuclear waste disposal Dynamic analysis and design considerations for high-level nuclear waste repositories

425 Indirect Rock Mass Investigations for Optimizing Borehole Drilling Programs. Volume 4. Wave Diffusion Geotomography TI <NOTE> Final rept. Sep 78-Mar 83

426 Choice of ion exchanger for British Nuclear Fuels Ltd.'s site ion exchange effluent plant Ion exchange technology.

427 Effect of composition and temperature on viscosity and electrical conductivity of borosilicate glasses for Hanford nuclear waste immobilization

428 Preliminary evaluation of microstructure and mechanical properties on low activation ferritic steels Alloy development for irradiation performance. Semiannual progress report for period ending March 31, 1985

429 | Potential use of transmission tomographic techniques for the quality checking of cemented waste drums. Progress report to 31 March 1985

430 Annual review of materials science. Volume 13

431 Tabulation of physical and mechanical property data from Borehole RRL-2

432. Interlaboratory testing of reference materials for comparative thermal conductivity measurement apparatus

433 | Round robin testing of thermal conductivity reference materials

434 Techniques for determining probabilities of geologic events and processes <Original Series/Collective> International Association for Mathematical Geology TI Studies in Mathematical Geology No. 4

435 The application of / sup $57 / \mathrm{Fe}$ Mossbauer spectroscopy to the characterization of nuclear waste forms

436 <English> The development and evaluation of a crosshole seismic system for crystalline rock environments

437 Characterization and compatibility of low and intermediate level waste forms Evaluation of low and intermediate level radioactive solidified waste forms and packages

438 Low and medium level waste forms: Guidelines and related research Management of low and intermediate level radioactive wastes 1988. V.1. Proceedings of an international symposium held in Stockholm, 16-20 May 1988 TI <Series/Collective> Proceedings series

439 Disposal of high-level radioactive waste in argillaceous formations: In situ and Taboratory heating experiments 
WHC-SD-TD-RPT-011

Revision 0

440 Plastic Solidification of Radioactive Wastes

441 Study of krypton encapsulation and adsorption in zeolite by means of neutron activation analysis

442 Identification and Measurement of Colloids in Groundwater CEC Natural analogue working group

443 Electrolytic decontamination of radioactive metallic wastes by alternating electrolys is in a neutral-salt electrolyte

444 Electrical resistivity imaging of groundwater problems

445 Methods for improved radwaste ion-exchange processing Spectrum '86: Proceedings: Volume 1

446 Method for making glass

447 Prediction of nuclear waste glass durability from natural analogs Nuclear waste management II TI <Series/Collective> Advances im ceramics. Volume 20

448

Viscosity and Resistivity of Waste Glasses

Relationship of glass viscosity, resistivity, liquidus, and durability to composition: First principles process-product models for vitrification of nuclear waste Annual meeting abstracts

450 Review of metal-matrix encapsulation of solidified radioactive high-level waste

451 Determination of in-situ thermal properties of Stripa granite from temperature measurements in the ful1-scale heater experiments: method and preliminary results. Technical information report No. 24

452 Large-scale brine inflow data report for room Q prior to November 25, 1991

453 Thermal calculations pertaining to a proposed Yucca Mountain nuclear waste repository

454 Study of trench covers to minimize infiltration at waste disposal sites. Task II report. Laboratory evaluation and computer modeling of trench cover design. Vol.2

455 In-situ tuff water migration/heater experiment: experimental plan

456 On-line analysis of solids and viscous liquids by transient infrared spectroscopy

457 Simulating the water balance of an arid site

458 Measurement of water potential in low-level waste management TI <Augmentation> Shallow Land Burial

459. Special waste-form Tysimeters: Arid

460 Use of noninvasive geophysical techniques for the in situ vitrification program

461 Use of noninvasive geophysical techniques for the In situ vitrification program. Volume 3, Discussion and recommendations

Use of noninvasive geophysical techniques for the in situ vitrification program. Volume 1 , Literature review

463 Evaluation test of the physical properties of the solidified simulated waste by hydrothermal solidification method Proceedings of the third international conference on nuclear fuel reprocessing and waste management, RECOD' 91

464 CHARACTERIZATION OF WEATHERED GLASS BY ANALYZING ANCIENT ARTIFACTS.

465 A formalism to generate probability distributions for performance-assessment modeling

466 Sediment mechanical response due to emplacement of a waste canister 
WHC-SD-TD-RPT-011

Revision 0

467 . Development of clay characterization methods for use in repository design with application to a natural $\mathrm{Ca}$ bentonite clay containing a redox front

468 I Neutronic and thermodynamic feasibility of /sup $233 /$ UF/sub $6 /-/$ sup $237 / \mathrm{NpF} / \mathrm{sub} 6 /$ fueled transmutation. reactor

469 i Thermal properties and modeling of aluminosilicate materials for low-temperature bulk applications

470 Thermal properties of fly ash-slag cement waste forms for disposal of Savannah River Plant salt waste Fly ash and coal conversion by-products:Characterization, utilization and disposal II TI <Series/Collective> Materials Research Society symposia proceedings. Vol 65

471 Chemical durability of glasses suitable for the storage of high level radioactive wastes. II. On the continuous leach method for the low temperature melting glasses of borosilicate system TI <Augmentation> $\mathrm{Si0} / \mathrm{sub} 2 /-\mathrm{B} / \mathrm{sub} 2 / 0 / \mathrm{sub} .3 /-\mathrm{Na} / \mathrm{sub} 2 / 0-\mathrm{Ca} 0-\mathrm{Al} /$ sub $2 / 0 /$ sub $3 /-\mathrm{Fe} / \mathrm{sub}$ $2 / 0 / \operatorname{sub} 3 /$

472 Present status of tritium research activities at universities in Japan

Fusion reactor design and technology. Proceedings of the third technical committee meeting and workshop organized by the IAEA and held in Tokyo; Japan, 5-16 0ctober 1981 TI <Series/Collective> Pane1 proceedings series

473 Transmissivities and heads derived from detailed analysis of Siblingen 1989 fluid logging data

474 Core analyses for selected samples from the Culebra Dolomite at the Waste Isolation Pilot Plant site

475 Design of erosion protection for long-term stability Management of uranium mill tajilings, low-level waste, and hazardous waste

476 Formulation and durability of tailored cementitious hosts applied to TRU waste generated at the Rocky Flats Plant

477 Possibilities of quality assurance on radioactive waste packages by computer tomography and other radiometric techniques Radioactive waste products - suitability for final disposal. Proceedings

478 Gamma-ray computed tomography of waste containers and conditioned radioactive waste in nuclear industry Proceedings of the 7 th international conference on NDE in the nuclear industry

479 Comparison of temperature calculations for an arbitrary high-level waste disposal configuration in salt formations

480 Thermodynamics of interaction of cobalt with silty loam and silty clay loam soils (Paper No. AL-42) <Series/Collective> Symposium on radiochemistry and radiation chemistry (held at Nagpur during 5-8 February 1990) : Preprints volume

481 Acceptance criteria and evaluation techniques for radioactive waste forms (II)

482 Analyses of Container Corrosion and Radionuclide Release from a Geologic Nuclear Waste Repository

483 Evaluation of structural behavior, geological and hydrogeological characteristics. Joint roughness characteristics and shear strength

484 Study on Adsorption Characteristics of Filtering Materials

485 Environmental applications of surface and airborne geophysics in mining 

radioactive waste involving volume reduction Waste Management ' 85 : Waste Isolation in the US - Technical Programs and Public Education. Volume 2. Waste policies and programs, low-level waste report RSI-0128

488 I Petrophysical characteristics of basalt in the vadose zone, Idaho National Engineering Laboratory, Eastern Snake River Plain, Idaho

489 Instrumentation and computational techniques and resulting geostatistical characterization of INEL vadose zone basalt

490 Thermal conductivity and thermal diffusivity of highly compacted bentonite

491 High level waste fixation in cermet form Alternate nuclear waste forms and interactions in geologic media

492 | West End Treatment Facility corrosion status

493 Thermodynamic stability of aqueous electrolytes at high temperatures: Eh-pH diagrams to $600 \mathrm{~K}$ IUPAC conference on chemical thermodynamics

494 i Thermal conductivity measurements in relation to the geothermal exploration of the Gorleben salt dome Thermal conductivity 18

495 Implications of thermophysical properties in geoscientific investigations for the disposal of nuclear waste in a salt dome

496 Geothermal in situ experiments in the Asse salt-mine Experiences de degagement de chaleur in situ dans les formations geologiques

497 I Thermal conductivity and thermal diffusivity measurements of salt rocks by different methods Thermal conductivity 18

498 A preliminary assessment of mineralogical criteria on the utility. of argillaceous rocks and minerals for high-level radioactive waste disposal

499 I Coupled hydrologic-thermomechanical experiments for radioactive waste isolation Earth Sciences Division annual report 1981

500 Experiments, conceptual design, preliminary cost estimates and schedules for an underground research facility

501 | A thermal properties measuring system for geologic materials Thermal conductivity 18

502 I Geomechanics activities conducted at Sandia National Laboratories in support of the waste isolation pilot plant

503 i Analysis of plutonium and uranium volatilities from mixed wastes in the molten salt processor

504 Evaluation of actinide volatilities in mixed waste processors

505 In situ electrochemical characterization of grouted radioactive waste

506 WATEQ3 geochemical mode1: thermodynamic data for several additional solids

507 Diffusion coefficients of airborne radioactive iodine and methyl iodide

508 Geohydrologic data from dri11-bit cuttings and rotary cores from test hole USW UZ-13, Yucca Mountain Area, Nye County, Nevada

509 i Geohydrologic data from test hole USW UZ-7, Yucca Mountain area, Nye County, Nevada

510 Stabilized fly ash as light weight concrete construction material Ash - a valuable resource. Papers. Volume 2 - concrete 
WHC-SD-TD-RPT-011

Revision 0

511 Hydrography Subseabed Disposal Project annual report, FY85 to termination of project: Physical Oceanography and Water Column Geochemistry Studies, October 1984 through May 1986 TI <Augmentation> Nares Abyssal Plain: Nares I Oceanographic Mission

512 - Physical and chemical characterization of borosilicate glasses containing Hanford high-level wastes

513 I STMI's industrial experience in low activity steel waste processing by melting Waste management 86. Volume 3: Low level waste

514 i Thermal property and density measurements of samples taken from drilling cores from potential geologic media

515 A radiological evaluation of phosphogypsum

516 Recommended analysis plan for the borehole plugging program potash core test

517 Strategy for evaluating the long-term stability of hole-plugging materials in their geological environments

518 Field geochemical studies of groundwaters in Nash Draw, southeastern New Mexico

519 I Seepage and transport modelling for a uranium tailings dam in northern Saskatchewan Proceedings of the Canadian Nuclear Society 2. international conference on radioactive waste management

520 Modeling the steady-state ISV (in situ vitrification) process: A 3-D finite element analysis of coupled thermal-electric fields

521 Thermal analysis of nuclear waste emplacement in welded tuff

522 Critical review of radiation effects on borosilicate glasses Proceedings of the international seminar on chemistry and process engineering for high-level liquid waste solidification

523 i Simulation possibilities of radiation effects in glasses used for conditioning high activity waste

524 Various methods for solidification of high level nuclear waste Transactions of the 1982 Eastern Regional American Nuclear Society student conference

525 i Studies of the Eleana Argillite. National waste terminal storage program

526 Thermal conductivity of silicic tuffs: predictive formalism and comparison with preliminary experimental results

527 Status of evaluation of tuff in southern Nevada for geologic disposal of high-level nuclear wastes

528 Bulk and thermal properties of the functional Tuffaceous Beds in holes USW G-1, UE-25 No. 1, and USW G-2, Yucca Mountain, Nevada

529 Thermal conductivity, bulk properties, and thermal stratigraphy of silicic tuffs from the upper portion of hole USW-G1, Yucca Mountain, Nye County, Nevada

530 Geotechnical studies at East Bull Lake Research Area (RA-7). Report No. MRL 87-94 (TR)

531 I Using QA classification to guide design and manage risk TI <Augmentation> Yucca Mountain Project

532 Analysis of groundwater from deep boreholes in Klipperaas

533

534 NUMERICAL MODELLING OF RADIONUCLIDE TRANSPORT IN A TWO-LAYER SYSTEM. Flowsheet finalisation for immobilisation of SGHWR wastes. Annual report - March 1983

535 i Heat of hydration measurements on cemented radioactive wastes. Part 1: cement-water pastes 
536 Development of a cement encapsulation process for spent powdered ion exchange materials Spectrum '86: Proceedings: Volume 1

537 Fluid and thermal sciences, 1984 annual report Thermal Response Studies. 1984 Subseabed Disposal Project annual report, October 1983 September 1984

538 . Development of incorporation of evaporator concentrate from pressurized water nuclear power reactors into asphalt compte rendu du colloque sur la gestion des dechets en provenance des reacteurs de puissance sur le site de la centrale. Zurich, 26-30 mars 1979

539 i Progress in the techniques of bituminizing liquid effluents of pressurized-water nuclear power plants

540 i Chemical Engineering Division reactor safety and physical property studies. Annual report, July 1975--June 1976 TI <Augmentation> LMFBR

541 Aqueous partial molar heat capacities and volumes for $\mathrm{NaReO}$ sub 4 and $\mathrm{NaTc0}$ sub 4 : The 1989 international chemical congress of Pacific Basin Societies: Abstracts of papers, Parts I and II

542 Radon: A Bibliography

543 Radionuclide transport by groundwater flow through the geosphere: current status 1989

544. Field manual for geohydrological sampling as applied to the radioactive waste disposal program

545 I Preliminary laboratory testing of selected cementitious material for the Yucca Mountain Project repository sealing program: Yucca Mountain Project

546 Energy stored in irradiated $\mathrm{NaCl}$

547 The thermal diffusivity of simulated nuclear waste giass below the glass transition temperature. Advances in materials characterization II. Vol.' 19

548 The remote monitoring of waste glass melter product Proceedings of high level radioactive waste management

549 Remote system for the monitoring of molten waste g7ass

550 Spanish research activities in the field of backfilling and sealing. A preliminary study of some spanish sedimentary (Madrid Basin) and hydrothermal (Almeria).bentonites Sealing of Radioactive Waste Repositories

551 A laboratory study of gas transport through intact clay samples

552 Laboratory Measured Material Properties of Granodiorite Climax Stock, Nevada Test Site

553 Evapotranspiration studies for protective barriers: FY 1988 status report

554

555

556

557

558 Thermal responses in underground experiments in a dome salt formation Compressible fluid flow through rocks of variable permeability Transport properties of Topopah Spring tuff A high-performance, low-density waste assay system Frontiers for petrophysics and borehole log analysis Workshop on borehole measurements and interpretation in scientific drilling identification of problems and proposals for their solution: proceedings

559 Fluidized-bed conversion of fuel processing wastes to solids for disposal

560 The application of moment methods to the analysis of fluid electrical conductivity logs in boreholes 
WHC-SD-TD-RPT-011

Revision 0

561 Thermal conductivity of multibarrier waste form components

562 Characterization of simulated low-level waste grout produced in a pilot-scale test

563 | Experimental and theoretical analysis of the radiative transfer within a sooty pool fire

564 Remote assessment of permeability/thermal diffusivity of consolidated clay sediments

565 Engineering study of tank leaks related to hydraulic retrieval of sludge from tank 241-C-106

566 Compaction and permeability of simulated waste

567 Effect of a low-permeability layer on calculated gas flow at Yucca Mountain

568 . Summary and evaluation of nuclear waste forms. Chapter 12 Radioactive waste forms for the future

569 I Characteristic properties of conditioned HLW under normal and incident disposal conditions Radioactive waste products - suitability for final disposal. Proceedings

570 Diffusion of chloride and uranium in compacted sodium bentonite Scientific basis for nuclear waste management XII <0riginal Series/Collective> Materials Research Society symposium proceedings. Volume 127

571 Long term crystallization behaviour of glasses at temperatures $\mathrm{T}<$ $\mathrm{T} / \mathrm{sub} \mathrm{g} / \mathrm{Scientific}$ basis for nuclear waste management XII <Original Series/Collective> Materials Research Society symposium proceedings. Volume 127

572 Theory and calculation of water distribution in bentonite in a thermal field Scientific basis for nuclear waste management XII <Original Series/Collective> Materials Research Society symposium proceedings. Volume 127

573 I Water uptake and swelling pressure in a bentonite-based backfill Scientific basis for nuclear waste management XII <Original Series/Collective> Materials Research Society symposium proceedings. Volume 127

574 Non destructive waste form and package characterization by computerized tomography Scientific basis for nuclear waste management XII <Original Series/Collective> Materials Research Society symposium proceedings. Volume 127

575 Review of science and technology for 1and-based geologic disposal of radioactive wastes Proceedings of the fourth Pacific Basin nuclear conference

576 Rock mass modification around a nuclear waste repository in welded tuff

577 Comparative study of geological, hydrological, and geophysical borehole investigations

578 Numerical calculation of thermal convection in porous media in two dimensions with applications to nuclear repository design

579 Thermal and radiation effects on properties of high level waste products Radioactive waste management and disposal

580 Removal of long-lived actinides from Purex type HAW raffinates by solvent extraction: preliminary results on the use of the neo-tridecano-hydroxamic acid $(H X-70)$ extractant 
581 I Study for the vitrification of high level liquid wastes by in-can melting process Semi-annual progress report of Power Reactor and Nuclear Fuel Development Corporation, Tokai Works. Ju1.-Dec. 1977

582 New developments in measurements technology relevant to the studies of deep geological repositories in bedded salt

583 Acoustic Wave Propagation in Fluids with Coupled Chemical Reactions TI 〈NOTE> Technical rept.

584 < <nglish> Physical aspects and modeling of deep-ocean dispersion related to subseabed disposal

585 Dose rate effects in radiation damage to vitrified radioactive waste

586 Potential of Gulf Coast salt domes for isolation of radioactive wastes Salt dome utilization and environmental considerations

587 Heat transfer coefficients for lead matrixing in disposal containers for used reactor fuel

588 Effect of metallic impurities on oxidation reaction of ion exchange resin. 2. Comparison of catalytic activity between six metals

589 Thermal and physicochemical properties important for the long term behavior of nuclear. waste glasses

590 Fabrication and characterization of MCC (Materials Characterization Center) approved testing material: ATM-10 glass

591 HYDRA-II: A hydrothermal analys is computer code: Volume 1, Equations and numerics

592 HYDRA-II: A Hydrothermal Analysis Computer Code: Volume 3, Verification/Validation Assessments

593 HYDRA-II: A Hydrothermal Analys is Computer Code: Volume 2, User's Manual

594

595

596

597

598 Infrared reflection spectroscopy--part of an integrated approach to

Solid-state nuclear detectors for monitoring low levels of tritium Research needs in cement-based waste forms

Geomechanical properties of rocks from the Altnabreac area

Study of Bidentate Compounds for Separation of Actinides from Commercial LWR Reprocessing Wastes MIIT (Materials Interface Interactions Test). sample analysis

Testing of high-level, waste forms under repository conditions.

Proceedings

599 Interpretation of the tracer testing conducted in the Leuggern borehole

600 Expected near-field thermal performance for nuclear waste repositories at potential salt sites: Technical report

601 Thermal aspects of the Eleana near-surface heater experiment

602 Test results and supporting analysis of a near-surface heater experiment in the Eleana argillite

603 Development of tank instrumentation: The search for appropriate monitoring

604 Production of Synroc powders by aikoxide hydrolysis Ceramic transactions

605 Effects of composition on waste glass properties Ceramics in nuclear waste management

$606 \quad$ <English> An improved technique for the determination of rock porosity TI <French Translation> Une methode amelioree pour la determination de la porosite des roches 
Solubility interpretation of leach tests Volume 1

608 Basic data report for drillhole H-16 (Waste Isolation Pilot Plant-WIPP) electrode potential of the TC(VII)/TC(IV)-oxide couple A survey of techniques for corrosion monitoring Radioactive waste treatment using zeolites Savannah River Plant environmental report. Annual report for 1987 Radionuclide correlations in low-level waste Validation of analytical laboratory data for the characterization of Hanford defense high-level chemical wastes Radioelement analysis: progress and problems

617 I State-of-the-art review of quality assurance techniques for vitrified high level waste

618 Thermodynamics of gas-metal-slag equilibria for applications in in situ and ex situ vitrification melts

619 I Processing of radioactive waste solution with zeolites, (1). Thermal-transformations of $\mathrm{Na}, \mathrm{Cs}$ and $\mathrm{Sr}$ forms of zeolites

620 i Properties of the solidified waste products from the plastic solidification pilot plant

621 Calibration of Far West Technology (FWT-60) radiachromic dye dosemeters

622 I Chemistry research and development. Progress report, November 1978-Apri门 1979

Chemistry research and development progress report, May-0ctober, 1978 Canadian research into radioactive nuclear waste disposal Aging geomembranes in uranium tailings leachate Field performance assessment of synthetic liners for uranium tailings ponds: a status report

Effect of bulk density on diffusion for cesium in compacted sodium bentonite

630 I Physical properties of nodular cast iron for shipping containers and safety analysis by fracture mechanics

631 Using borosilicate glass as a HLW storage medium.

632 WIPP simulated DHLW tests: Status and initial in situ backfill thermal conductivities Proceedings of the twenty-sixth IEEE cement industry technical conference

633

634

635

636 Heater test 1, Climax Stock granite, Nevada Hydrogeology of the unsaturated zone, Yucca Mountain, Nevada Cement technology for plugging boreholes in radioactive-waste-repository sites. Progress report, October 1, 1978-September 30, 1979

Cement technology for plugging boreholes in radioactive waste repository sites. Progress report, October 1, 1977--September 30, 1978 
WHC-SD-TD-RPT-011

Revision 0

Pretest reference calculation for. the $18-\mathrm{W} / \mathrm{m} / \mathrm{sup} 2 /$ Mockup for Defense High-Level Waste (WIPP Room $A$ in situ experiment)

639 Thermal conductivity of the rocks in the Bureau of Mines Standard Rock Suite monitoring nuclear waste repositories
Mechanisms of the rapid dissolution of plutonium dioxide in acidic media under oxidizing or reducing conditions Proceedings of Transuranium Elements
644 Stored energy of gamma-irradiated WIPP salt
645 Proposed model for the thermal conductivity of dry and water-saturated tuff

646 Effects of composition, porosity, bedding-plane orientation, water content and a joint on the thermal conductivity of tuff

647 I Thermal conductivity of tuff: The effects of composition, porosity, bedding-plane orientation, water content, and a joint

648 I Thermal conductivity of bentonite/quartz high-level waste package backfill

649 I Feasibility study for the design of a simulated radioactive waste repository facility. Volume 1. Text-References

650 The use of a thermal probe to determine the effective thermal conductivity of packaging contents

UTtimate disposal of high-level atomic waste by incorporation in glass Preliminary Analysis of Geophysical Logs from the WT Series of Drill Holes, Yucca Mountain, Nye County, Nevada 653 i Comparison of calculations and in situ results for
test room at the Waste Isolation Pilot Plant (WIPP)

655 Testing of bituminized ion-exchange resin waste products from a nuclear power plant TI <Augmentation> Gamma rays

656 i Thermomechanical properties of Stripa granite Earth Sciences Division annual report 1980

657 Seismic characterization of fracture properties

658 Nondestructive techniques for evaluating the integrity of vitrified solids, 2

661 Sediment Characteristics of the 2800 Meter Altantic Nuclear Waste Disposal Site: Radionuclide Retention Potential TI <NOTE> Technical note

I First look at roadheader construction and estimating techniques for site characterization at Yucca Mountain, Nevada.

663 Properties of Solidified Radioactive Wastes from Commercial LWRs

664 Propertis of solidified radioactive wastes from commercial LWRs

665 Application of borehole geophysics at an experimental waste storage site 
WHC-SD-TD-RPT-011

Revision 0

666 Thermomechanical and macropermeability experiments in the Stripa granite: status report. Proceedings of workshop on thermomechanical-hydrochemical modeling for a hardrock waste repository

667 . Thermal conductivity of solidified waste products

668 Thermal and electrical conductivity of metals embedded with ceramic granules Thermal conductivity. Vol. 17

669 Thermal conductivity measurements on granule-based composites

670 Transformation characteristics of LaV/sub $\mathrm{x} / \mathrm{Nb} / \mathrm{sub} 1-\mathrm{x} / 0 / \mathrm{sub} 4 /$ compounds Geochemical behavior of disposed radioactive waste TI <Series/Collective> ACS symposium series 246

671 Standard Gibbs free energies of formation at the temperature $303.15 \mathrm{~K}$ of four uranyl silicates: soddyite, uranophane, sodium boltwoodite, and sodium weeksite

672 Measurement of the physical properties of nuclear aerosols

673 Radon emanation characteristics of uranium mill tailings Uranium Mill Tailings Management

674 i Dewatering of liquid radioactive wastes in thin-film rotary evaporators

$675^{\circ}$ The thermal conductivity of seven thermal/mechanical units at Yucca Mountain, Nevada TI <Augmentation> Yucca Mountain Project

676. I Thermal-conductivity data for tuffs from the unsaturated zone at Yucca Mountain, Nevada: Yucca Mountain Project TI <Augmentation> Yucca Mountain Project

677 Calculation of heat capacities for tuffaceous units from the unsaturated zone at Yucca Mountain, Nevada TI <Augmentation> Yucca Mountain Project

678 Calculation of experiment uncertainty in laboratory determination of several geoengineering properties of tuffs from Yucca Mountain, Nevada TI <Augmentation> Yucca Mountain Project.

679 Immobilization of tritiated water by hydrothermal hot-pressing

680 Fixation of radioactive waste by HHP method Proceedings of the third international symposium on advanced nuclear energy research

681 I Effect of porous surface layer on leaching rate of radionuclide from cementitious waste form

682 The complexation behavior of neptunium and plutonium with nitrilotriacetic acid

683 Measurements of sediment temperatures, conductivity and heat flow in the North Atlantic and their relevance to radioactive waste disposal.

684 Experience with full-scale leaching of low and medium level waste Testing, evaluation and shallow land burial of low and medium radioactive waste forms

685

686

687 | Radionuclide sorption and migration studies of getters for backfill

A capacitance-based proximity sensor for whole arm obstacle avoidance Experimenta] relationship between the specific resistance of a HEPA (High Efficiency Particulate Air) filter and particle diameters of different aerosol materials barriers

688 APPLICATION OF ESEM TO ENVIRONMENTAL COLLOIDS

689 Comparison of predicted and observed subsurface-surface seismic spectral ratios 
WHC-SD-TD-RPT-011

Revision 0

690. Current status of technology for hydrogeological investigation, 2. Geophysical logging

691 Analysis relating to solidification of simulated high level liquid wastes, (1). Determination of cesium by flameless atomic absorption spectrometry Semi-annual progress report of Power Reactor and Nuclear Fuel Development Corporation, Tokai Works. Jul-Dec 1978

692

693

694 User's manual for the NEFTRAN II computer code Thermal gradient migration of brine inclusions in salt In-situ heat transfer experiment Subseabed disposal program annual report, January-December 1980. Volume II. Appendices (principal investigator progress reports). Part 1

695

Interpretation of magnetotelluric data: Pasco Basin, south central Washington

696

697 Iodine Adsorption on Steel in Helium

698 Optimization method for dimensioning a geological HLW waste repository Thermochemistry and structure of model waste glass compositions Scientific basis for nuclear waste management 13

699 I Performance predictions for mechanical excavators in Yucca Mountain - tuffs. Yucca Mountain Site Characterization Project

700 Performance predictions for mechanical excavators in Yucca Mountain tuffs TI <Augmentation> Yucca Mountain Project

701 Effect of platinoids on French LWR reference glass properties

702 Heat Transfer in vitrified radioactive waste Glass and glass-ceramics for nuclear waste management

703 Application of geophysical logs to estimate moisture-content profiles in unsaturated tuff, Yuccá Mountain, Nevada

704 Characterization of reference materials for the Barrier Materials Test Program

705 Subsolidus sintering of SYNROC: II. Materials selections, process improvements, waste form evaluations

706 Development of waste form characterization technology

707 Effect of miscibility and soil water content in movement of mixed waste

708 Temperatures and stresses in the vicinity of a nuclear-waste repository in welded tuff Proceedings of the workshop on near-field phenomena in geologic repositories for radioactive waste, Seattle, 31 Aug - 3 Sep 1981

709 Operational and technical results from the spent fuel test - Climax 1985 proceedings of the Institute of Environmental Sciences 31st annual technical meeting

710 Excavation and drilling at a spent-fuel test facility in granitic rock

711 <English> Seismic velocities and attenuation in a heated underground granitic repository

712 Cross-hole investigation of a rock mass subjected to heating

713 Fixation of radioactive residues. Quarterly progress report, January-March 1961

714 Cementitious materials for the immobilisation of radioactive wastes. Paper 2: cement rheology, microstructure, porosity and strength

715 I Abyssal studies (free-fa11 deep CTD). First annual report, January 31, 1974-June 30, 1975 
WHC-SD-TD-RPT-011

Revision 0

716 Status and integration of the gas generation studies performed for the Hydrogen Safety Program

717 Status and integration of the gas generation studies performed for the Hydrogen Safety Program. FY-1992. Annual report TI <NOTE> Progress rept

718 Alternative methods for $/$ sup $85 / \mathrm{Kr}$ ultimate storage

719 Alternative Methods for exp $85 \mathrm{Kr}$ U1timate Storage

720 Long-term storage of radioactive krypton by fixation in zeolite $5 \mathrm{~A}$ 17 th DOE nuclear air cleaning conference: proceedings. Volume 1

721 i Recirculation within a glass mixture subjected to external and resistive heating

722 I Characterization of low-level liquid wastes at the Oak Ridge National Laboratory

723 Analysis of simulated low-level waste glass forms

724 Differential scanning calorimetry of metamict Pu-substituted zirconolite

725 i Laboratory tests to determine hydraulic and thermal properties of bentonite-based backfill materials

726 I Physical-chemical studies of transuranium elements. Progress report, April 1, 1979-March 31, 1980

727 Characterization of the first core sample of neutralized current acid waste from double-shel1 tank 101-AZ

728 Consolidation, permeability, and strength of crushed salt/bentonite mixtures with application to the WIPP (Waste Isolation Pilot Plant)

729 Radiation, thermal and mechanical effects on low and medium active conditioned waste Radioactive waste management and disposal

730 i Calculation of thermodynamic properties for monomeric U(IV) hydrolysis products at $298.15 \mathrm{~K}$ and zero ionic strength

731 Thermodynamic tables for nuclear waste isolation: Vol. 1, Aqueous solutions database

732 I Thermodynamic tables for nuclear waste isolation: Aqueous solutions database

733 Database of chemical properties of nuclear waste elements in aqueous solutions Earth Sciences Division annual report 1980

734 Analyses of soils at commercial radioactive-waste-disposal sites TI <Augmentation> Barnwe 11, SC^ Richland, WA

735 Analyses of soils from the low-level radioactive waste disposal sites at Barnwell, SC and Richland, WA

736 Analyses of soils. from an area adjacent to the low-level radioactive waste disposal site at Sheffield, Illinois

737 In situ vitrification and the effects of soil additives TI A mixture experiment case study

738 i Sorption measurements performed under site-specific conditions - Maxey Flats, Kentucky, and West Valley, New York, disposal sites <Augmentation> Shallow Tand burial

739 i Tomographic analysis of crosshole seismic measurements In situ experiments in granite associated with the disposal of radioactive waste. Proceedings of the symposium TI Les experiences in situ dans du granite relatives a l'evacuation des dechets radioactifs. Compte rendu du symposium

740 Measurement of rock properties at elevated pressures and temperatures TI <Series/Collective> ASTM Special Technical Publication. 869 
WHC-SD-TD-RPT-011

Revision 0

741 Conductivity mapping of underground flow channels and moisture anomalies in carbonate terrain using electromagnetic methods

742 I Fixation of radioactive residues. Quarterly progress report, January-March 1966

743 Review of heat dissipation in geologic media Alternate nuclear waste forms and interactions in geologic media

744 Interactions of low-level, liquid radioactive wastes with soils. 3. Interaction of waste radionuclides with soil from horizons of two soil series

745 Fractured Apache leap tuff: Interstitial, hydraulic, pneumatic, and thermal properties Waste management '90: Working towards a cleaner environment: Waste processing, transportation, storage and disposal, technical programs and public education. Volume 2, HLW and LLW technology: Proceedings

746 I Packaging of alpha waste for final disposal Radioactive waste management and disposal

747 Thermo-mechanical pre-test analyses for the HAW test field

748 On the constitutive relations of rock salt

749 Combustion synthesis of calcium and lithium gallides 1992 TMS annual meeting (Abstracts)

750 TOUGH2: A general-purpose numerical simulator for multiphase nonisothermal flows Earth Sciences Division annual report 1990

751

752

753

754

755

Swelling pressure of highly compacted bentonite

Executive summary and general conclusions of the rock sealing project

Influence of various excavation techniques on the structure and physical properties of 'near-field' rock around large boreholes

Ga migration through $M X-80$ bentonite

Method for binding liquid-containing radioactive wastes and kneading machine therefor TI <Augmentation> Patent

756 i Physical and thermal properties of simulated nuclear waste glasses and their melts. Final report

757 Volume-temperature relationships in simulated glass forming nuclear waste melts Advances in materials characterization TI <Series/Collective> Materials Science Research

758 Thermal properties of clay-based buffer materials for a nuclear fuel waste disposal vault

759 Sorptive diffusion in clay gels Earth Sciences Division annual report 1980

760 An evaluation of the resistivity anisotropy of the clays at the Down Ampney fault research site

761 New developments in measurement technology relevant to the studies of deep geological repositories in domed salt and basalt

762 i Changes in moisture content detected by the neutron logging probe Prototype Engineered Barrier System Field Tests (PEBSFT). Progress report through November 1, 1988

763 Climax granite test results

764

765

Waste isolation projects, FY 1977

Critical review of the chemistry and thermodynamics of technetium and some of its inorganic compounds and aqueous species

766 Method for determining the fuel contribution to the source term in transport casks 
WHC-SD-TD-RPT-011

Revision 0

767 Unsaturated fractured rock characterization methods and data sets at the Apache Leap Tuff Site

768 Standardisation of techniques for evaluation of solidified high level waste product: a status report

769 A sensitivity study of brine transport into a borehole containing a commercial high-level wastes canister TI <Augmentation> Brine inclusions in thermal gradient

770 Deterministic geologic processes and stochastic modeling

771 Identification of characteristics which influence repository design: tuff. Final report (Task 1), June 1981-March 1982

772. I Chemical modelling studies in support of radiological risk assessments of radioactive waste disposal 1984-86

773 Experimental studies of actinides in molten salts

774 Quantitative measurements of fly ash, slag, and cement in limestone-based blends by Fourier transform infrared-attenuated total reflectance method

775 Comparison of transmission and reflection Fourier transform infrared methods for the analysis of cement blends

776 i Natural convection experiments with a finite-length, vertical, cylindrical heat source in a water-saturated porous medium

777 I Natural convection experiments about a finite-length cylindrical heat source in a liquid-saturated porous medium Thermal Response Studies. 1984 Subseabed Disposal Project annual report, October 1983 September 1984

778 | Project plan for inspection and evaluation of Nuclear Fuel Services high-level waste storage system

779 | <nglish> Thermal properties of bentonite-sand and kaolinite-sand mixtures

780 Development and testing of SYNROC $C$ as a high level nuclear waste form Scientific basis for nuclear waste management TI <Augmentation> Australian Atomic Energy Commission

781 Methods for determining radionuclide retardation factors: status report

782 Diffusion of tritiated water and chloride in basalt-bentonite mixtures

783 Investigation of the effect of the uranyl ion on proton-spin-relaxation times in aqueous solutions

784 I Effects on electrical parameters at Athens Greece by radioactive fallout from a nuclear power plant accident

785 Iank 101-SY Window $C$ core sample results and interpretation

786 Yucca Mountain Project: Preliminary shaft 7 iner design criteria and methodology guide TI <Augmentation> Yucca Mountain Project

787 | Potential for using a six-phase, alternating current power supply system for in situ vitrification

788 Instrument for determining viscosities and electrical resistivities of molten glass candidates for immobilizing Hanford nuclear defense wastes

789 Nuclear waste immobilisation in SYNROC

790 Irradiation effects on borosilicate waste glasses

791 Materials characterization center workshop on the irradiation effects in nuclear waste forms 
Studies of cement grouts and grouting techniques for sealing a nuclear fuel waste disposal vault cementitious materials Pore structure and permeability of Research Society symposium proceedings Heat transfer analyses for grout disposal of radioactive double-shell slurry and customer wastes

794 model

Preliminary interpretation of paleomagnetic and magnetic property data from drill holes USW G-1, G-2, GU-3, G-3, and $V H-1$ and surface localities in the vicinity of Yucca Mountain, Nye County, Nevada

798 The solidification of low level radioactive organic fluids with Envirostone Gypsum Cement Waste isolation in the U.S., technical programs and public education. Vol. 2

799 Characterization on the high-level waste glasses. Annual report

800 The HAW project: demonstration facility for the disposal of high-level waste in salt

801 A program for volume reduction, packaging and disposal of activated core components stored in BWR fuel pools Waste management 86 . Volume 3: Low level waste

802

Soil (sediment) properties of twelve Hanford wells with geologic interpretation

803

Geology of high-level nuclear waste disposal: an introduction TI <Augmentation> Glossary included

804 Geology of high-level nuclear waste disposal

805

PSU/WES Interlaboratory Comparative Methodology Study of an

Experimental Cementitious Repository Seal Material. Report 1.

Short-Term Results. Revised TI <NOTE> Miscellaneous paper

806

Borehole cement and rock properties studies. Progress report for the period up to 1 August 1976

807 PSU/WES interlaboratory comparative methodology study of an experimental cementitious repository seal material

808 i Regulatory controls on the hydrogeological characterization of a mixed waste disposal site, Radioactive Waste Management Complex, Idaho National Engineering Laboratory

809 Size and density of a / sup 242/Pu colloid

810 Bench-scale fixation of soils from the Tacoma Tar Pits Superfund Site. Final report

811 Interpretation of piezometer cone testing of tailings Management of uranium mill tailings, low-level waste, and hazardous waste

812 Constitutive modeling of the behavior of a sand-bentonite mixture

813 Finite Elements in Water Resources: Proceedings of the International Conference (6th) Held in Lisboa, Portugal in. June 1986

814 Physical and chemical characteristics of lead-iron phosphate nuclear waste glasses

815 Electrical-conductivity measurements of leachates for the rapid assessment of wasteform corrosion resistance

816 Electrical conductivity measurements of leachates for the rapid assessment of waste from corrosion resistance

817 Surface layer formation on corroded nuclear waste glasses 
WHC-SD-TD-RPT-011

Revision 0

818 Bentonite pellets, an alternative buffer material for spent fuel canister deposition holes Sealing of Radioactive Waste Repositories

819 Thermodynamic data bases at elevated temperatures using experimental methods IUPAC conference on chemical thermodynamics

820 Thermodynamic data for selected electrolytes at elevated temperatures

821

Heat capacity data for selected cesium- and iodine-containing electrolytes in water at elevated temperatures

822 Selective organic ion exchangers for the removal of cesium from highly salted alkaline nuclear wastes (Paper No. AL-35) <Series/Collective> Symposium on radiochemistry and radiation chemistry (held at Nagpur during 5-8 February 1990) : Preprints volume

823 I A source term methodology for spent fuel cask containment evaluations The 9th international symposium on the packaging and transportation of radioactive materials. Proceedings: Volume 1

824 Effect of dry density on diffusion of some radionuclides in compacted sodium bentonite

825 Rock mass behaviour considering water flow and heat transfer

Numerical methods in geomechanics

826 I Volumetric change of simulated radioactive waste glass irradiated by electron accelerator <Augmentation> Silica glass

827 Volumetric change of simulated radioactive waste glasses irradiated by the /sup $10 / B(n, \ldots$ cap alpha..)/sup $7 / L i$ reaction as simulation of actinide irradiation

828

Thermal conductivity of simulated radioactive waste glass

829

Determination of heat capacity of simulated radioactive waste glasses by drop calorimetry

830

831

832

Seismic investigations at Wellenberg

Synthetic magnesium aluminosilicates in radioactive waste management

CTD data from the Madeira and Iberian Abyssal PTains. CHARLES DARWIN cruises $3 / 85$ and $9 A / 85$

833 I CTD data from the N.E. Atlantic 31 deg N - $46 \operatorname{deg} N$, July 1982

Discovery cruise 130 TI <Augmentation> Ocean disposal of high level radioactive waste

834 I Benthic boundary layer - IOS Observational Programme: Discovery Gap measurements, March 1984

835 Characterization of samples of a cement-borehole plug in bedded evaporites

836 Comparison of tailored cement formulations for borehole plugging in crystalline silicate rocks and evaporite mineral sequences Scientific basis for nuclear waste management

837 Energy storage in borosilicate glasses

838 Modelling of variable-density groundwater flow with respect to planned radioactive waste disposal sites in West Germany - validation activities and first results. Safety Assessment of Radioactive Waste Repositories

839 i Physical properties of Hanford metal waste

840 Magnetism and magnetic mineralogy of ash flow tuffs from Yucca Mountain, Nevada

841 Predicting permeability and electrical conductivity of sedimentary rocks from microgeometry

842 Embedding of Spent Fuel Cladding in Metallic Materials and Graphite Matrix 
WHC-SD-TD-RPT-011

Revision 0

843 Thermal simulation of drift emplacement. Geotechnical and geophysical investigations in and around backfilled galleries Proceedings of the Joint United States/Federal Republic of Germany Technical Exchange Conferences on Nuclear Waste

844 Thermal simulation of drift emplacement: Experiment to demonstrate direct disposal in the Asse salt mine Geological disposal of spent fuel and high level and alpha bearing wastes TI <0riginal Series/Collective> Proceedings series

845 New test set up for the in situ determination of percolation parameters in rock Low flow, low-permeability measurements in largely impermeable rocks. Proceedings of the NEA/AIEA workshop, Paris, 19-21 Mar 1979

846 Microwave processing of simulated nuclear waste glass 93rd Annual Meeting and Exposition. Abstracts

847 STATE-OF-THE-ART DISCUSSION ON THE SOLVENT EXTRACTION REAGENTS USED FOR THE RECOVERY OF COPPER FROM DILUTE SULFURIC ACID LEACH SOLUTIONS.

848

849 Remote monitoring of molten radioactive glass <English> Demonstrate of a decision analysis methodology for assessing the performance of the Yucca Mountain site in southern Nevada

850 Laboratory studies on the adsorption of radioiodine and iodine compounds on activated carbon

851 I Environmental monitoring considerations for low-level waste disposal sites

852 Determination of a constitutive law for salt at elevated temperature and pressure Measurement of rock properties at elevated pressures and temperatures TI <Series/Collective> ASTM Special Technical Publication 869

853 Radon Isotopes and Short-Lived Products of Their Disintegration in Nature

854 Granulated inorganic sorbent and method of obtaining it

855 Determination of Distribution Ratios and Diffusion Coefficients of Neptunium, Americium and Curium in Soil-Aquatic Environments. Annual Report, August 1, 1975--JuTy 31, 1976

856 Permeability and mechanical properties of bentonite-sand mixture for sealing LLW (Low Level Radioactive Wastes) repositories Transactions of the 11 th international conference on structural mechanics in reactor technology

857 Estimation of natural thorium in low level effluents from processing plants

858 i Chemical, physical, and mineralogical characterization of fifteen sandstones for radionuclide sorption studies

859 Design of an intermediate-scale experiment to validate unsaturated-zone transport models Proceedings of high level radioactive waste management

860 Compilation/validation of thermodynamic data for plutonium for nuclear waste disposal.

861 Estimation of radionuclide retardation in the Culebra Dolomite at the WIPP site, southeastern New Mexico The 1989 international chemical congress of Pacific Basin Societies: Abstracts of papers, Parts I and II

862 Borehole determination of formation thermal conductivity using $a^{*}$ thermal pulse from injected fluid 
863 Geotechnical studies for subseabed disposal: high level radioactive wastes Subseabed disposal program annual report, January-September 1981. Volume II. Appendices (principal investigator progress reports). Part 2

864 Cruise report on geotechnical core processing^ Cruise: ATLAS-84, ISHTE Component Test, R/V Melville Sept.-Oct., 1984 Thermal Response Studies. 1984 Subseabed Disposal Project annual report, October 1983 September 1984

865 Thermodynamic properties of chemical species of waste radionuclides NRC nuclear waste geochemistry 1983

866 Characterization of the Topopah spring and Tiva Canyon tuffs at Yucca Mountain TI Effective diffusivities and pore properties Proceedings of high level radioactive waste management

867 Zircons and fluids: An experimental investigation with applications for radioactive waste disposal

868 Measurements of the dielectric constant and dielectric loss at $\mathrm{MHz}$ and $\mathrm{GHz}$ frequencies for ionic exchange resin embedded in concrete and. bitumen

869 Diffusion measurements in crystalline rocks

870 Diffusivities in crystalline rock materials

871 Diffusion in crystalline rocks of some sorbing and nonsorbing species

872 Diffusion in crystalline rocks Scientific basis for nuclear waste management $V$

873 <English> Diffusivity measurements and electrical resistivity measurements in rock samples under mechanical stress TI < French Translation> Diffusivite et resistivite electrique dans des echantilions de roche sous contrainte mecanique

874 Physical, chemical and dewatering characteristics of Ba/RaSO/sub 4/ sludges from uranium milling

875 Performance study: Purex deep-bed fiberglas filter

876 Studies of electrical and electromagnetic methods for characterizing salt properties at the WIPP (Waste Isolation Pilot Project) Site, New Mexico

877 Technical Division quarterly progress report, April 1--June 30, 1977

878 Technical Division quarterly progress report, January 1--March 31, 1977

879 Technical Division quarterly progess report, July 1--September 30, 1977

880 Effects of heating and swelling processes on the effective thermal conductivity of buffer materials High level radioactive waste and spent fuel management

881 A method for monitoring of uranium extraction zone from axial temperature profile in a pulsed column High level radioactive waste and spent fue 7 management

882 Below Regulatory Concern Owners Group: Nonradiologic characterization and environmental assessment of BRC (Below-Regulatory Concern) waste: Final report

883 Effects of various radiation source characteristics on shielding requirements at the potential Yucca Mountain repository 'TI <Augmentation> Yucca Mountain Project

884 Contained $x$-ray diffraction goniometer for examination of radioactive materials 
WHC-SD-TD-RPT-011

Revision 0

885

Assessment of dome-fill technology and potential fill materials for the Hanford single-shell tanks

886

887

High level radioactive waste management

888

Determination of tritium activity in $0 i l$ samples by liquid scintillation counting

889

890

Soda ash treatment of a strontium-90-contaminated groundwater seep

Determination of the areal distribution of / sup $90 / \mathrm{Sr}$ in groundwater via single-use boreholes

891

Noble Gases

892

Properties of radioactive calcine retrieved from the second calcined solids storage facility at ICPP

893

Requested information regarding remote analytical capabilities

894

895 FINITE ELEMENT CALCULATIONS OF TEMPERATURE FIELDS I

A proposed protocol for evaluation of solidified wastes

Proceedings

of the 20th annual conference of the Pollution Control Association of Ontario

896 I Thermophysical properties of rocks: a perspective on data needs, sources and accuracy

897 i <English> Regional survey for He anomalies in Canadian shield lakes: sources of variation and implications for nuclear fuel waste management

898

USGS studies of physical--chemical relationships in salt repositories

National waste terminal storage program

899 Reference thermal and thermal/mechanical analyses of drifts for vertical and horizontal emplacement of nuclear waste in a repository in tuff

900 Ion exchange versus evaporation

901 Evaluation of concrete as a matrix for solidification of Savannah River Plant waste

902 <English> Prediction of dilation and permeability changes in rock salt

903 I A deformation and thermodynamic model for hydride precipitation kinetics in spent fuel cladding

904 A dose to curie conversion methodology Waste management '87: Waste isolation in the US, technical programs, and public education TI <Series/Collective> Volume 3 - Low-level waste

905 I Minutes of the Tank Waste Science Panel meeting, July 20, 1990: Hanford Tank Safety Project

906 Minutes of the Tank Waste Science Panel meeting September 13--14, 1990

907 Chemical data bases for the Multimedia Environmental Pollutant Assessment System (MEPAS)

908. Large-scale demonstration tests on backfilling: Numerical calculations using ANTEMP/ANSALT Proceedings of the Joint United States/Federal Republic of Germany Technical Exchange Conferences on Nuclear Waste

909 Isotopes of water. A biblography TI <Augmentation> Book

910 Evaluation of the graphite electrode DC arc furnace for the treatment of INEL buried wastes 
WHC-SD-TD-RPT-011

Revision 0

911 Structural changes in irreversibly densified fused silica: implications for the chemical resistance of high level nuclear waste glasses

912 Thermal conductivity measurements of Pacific illite sediment/sup 1/

913 Pressure effects on thermal conductivity and expansion of geologic materials

914 Thermal properties measurements on rocksalt samples from the site of the proposed Waste Isolation Pilot Piant

915 | Thermal conductivity of rocksalt and other geologic materials from the site of the proposed waste isolation pilot plant

916

917

918

919

920 Characterization of borosilicate glasses containing simulated Development of empirical relationships for hydrofracture grouts In-Situ Grouting of Uranium-Mill-Tailings Piles: An Assessment In situ and laboratory heating experiments in clay rocks Corrosion studies on containment materials for vitrified high level

920 Characterization of borosilicate glasses containing simulated high-level radioactive wastes from PNC Ceramics in nuclear waste management

921 Application of SYNROC to high-level defense wastes Alternate nuclear waste forms and interactions in geologic media

922 I Simultaneous spectrophotometric determination of uranium(VI) and iron(III) in purex process streams (Preprint no. AC-08) International symposium on radiochemistry and radiation chemistry (P1utonium - 50 years) (held at Bombay during February 4-7, 1991): Preprints volume Dighem sup II airborne electromagnetic/resistivity/magnetic VLF survey of the Chalk River research area, Ontario Proceedings of a workshop on geophysical and related geoscientific research at Chalk River, Ontario

924 | A review of geophysical investigations at the site of Chalk River Nuclear Laboratories, Ontario

Sodium diffusion in the nuclear waste glass GP $98 / 12$

Material constitutive model for jointed rock mass behavior

PTRACK: A particle tracking program for evaluation travel path/travel time uncertainties

929

Calculations on HYDROCOIN level 2, case 1 using the GWHRT flow model.

Thermal convection and conduction around a field heat transfer experiment

930

931 I Solid state containment of noble gases in sputter deposited metals and

Scale dependence of effective media properties

Geoengineering properties of potential repository units at Yucca

Mountain, southern Nevada low density glasses Management of gaseous wastes from nuclear facilities. Proceedings of an international symposium jointly organized by the IAEA and the NEA of the OECD and held in Vienna, 18-22 February 1980

932 I Kinetics of sorption of some long-lived fission products on inorganic sorbents Use of inorganic sorbents for treatment of 1iquid radioactive waste and backfill of underground repositories

933 I Development, implementation, and early results: Test Series D, Phase 1 of the smal1-scale seal performance tests

934 i Density enhancement of polyethylene solidified wastes. Thickening with sodium sulfate anhydride 
935 Classification of lithological units based on geophysical borehole logging - data from the Stripa mine

936 I Aqueous corrosion of borosilicate glasses nature and properties of alteration layers

937 | Proceedings of the 1980 DOE statistical symposium TI <Augmentation> Lead Abstract

938 I Advances in the study of far-field phenomena affecting repository performance

939 I Preclosure monitoring and performance confirmation at Yucca Mountain: Applicability of geophysical, geohydrological, and geochemical methods

940 I Theory and application of the PORFLOW model for analysis of coupled flow, heat, and radionuclide transport in porous media Coupled processes associated with nuclear waste repositories

941 i Coupled triaxial testing of rock salt specimens Coupled processes associated with nuclear waste repositories

942 I THAC-SIP-3D: a three-dimensional, transient heat analysis code using the strongly implicit procedure TI <Augmentation> In FORTRAN IV for IBM 360 and 370

943 i Near-surface heater experiments in argillaceous rocks In situ heating experiments in geological formations. Seminar, Ludvika, Sweden, 13-15 Sep 1978. Proceedings TI Experiences de degagement de chaleur in situ dans les formations geologiques. Seminaire, Ludvika, Suede, 13-15 sep 1978. Compte rendu

944 i Hydrolytic resistance of glass obtained by the vitrification of low-level waste arising in Czechoslovak nuclear power plants and other properties of the product - planned experiment

945 Measurement of thermal conductivity and thermal expansion at elevated temperatures and pressures Measurement of rock properties at elevated pressures and temperatures TI <Series/Collective> ASTM Special Technical Publication 869

946 Acid-leaching of alkoxide-route Synroc precursor powders

947 Impurities in rock-salt: consequences for the temperature increases at the disposal of high-level nuclear waste TI <Augmentation> Kainite, Kieserite

948 Analysis and predictions of water and solute transport in a large lysimeter Modeling study of solute transport in the unsaturated zone: workshop proceedings

949 Low and medium level waste forms: guidelines and related research

950 In situ investigations at Avery Is land Proceedings of workshop on thermomechanical-hydrochemical modeling for a hardrock waste repository

951 Thermomechanical assessment of in situ heater tests in DOE salt at Avery Island, Louisiana

952 I A modified method for the synthesis of polycondensate phenolic resin with iminodiacetic caid (IDA) functional group for treatment of alkaline waste from reprocessing plants (Preprint no. SST-10) International symposium on radiochemistry and radiation chemistry (Plutonium - 50 years) (held at Bombay during February 4-7, 1991): Preprints volume

953 I Development of suitable vitrified radioactive waste products with low formation temperatures and improved leach resistance - a practical approach 
WHC-SD-TD-RPT-011

Revision 0

954 i 1984 EC Enquiry into the Needs for Nuclear Reference Materials ( $Z$ > 89)

955 Method for qual ification of cementation process and its application to a vibration mixer Proceedings of the Seminar on Management Options for Low and Intermediate Level Wastes in Latin America

956 | Durability, mechanical, and thermal properties of experimental glass-ceramic forms for immobilizing ICPP high level waste

957 Incorporation of ashes of radioactive waste combustion in clay-based ceramic matrices

958 Some aspects of regional flow of variable-density groundwater in crystalline basement rock of Sweden

959 Comparison and evaluation of field and numerical results from the Site A heater test at Avery Island

960 I Parametric study involving thermo/viscoelastic analyses of a room and pillar configuration

961 I Preliminary thermomechanical analyses of a conceptual nuclear waste repository at four salt sites

962 I Fabrication and characterization of MCC approved testing material ATM-8 glass

963 I A system for measuring moisture transients in clay-based barrier materials Proceedings of high level radioactive waste management

964 Characterization of R7T7 LWR reference glass Requirements for waste acceptance and quality control. Proceedings <original Series/Collective> BfS Schriften

965 i Recycle stream impacts on feed treatment flowsheets and glass formulation for the Hanford Waste Vitrification Plant

966 I Radiation effects in crystalline high-level nuclear waste solids Scientific basis for nuclear waste management. Volume 3

967 Self-radiation damage in actinide host phases of nuclear waste forms 968. FY-87 packing fabrication techniques (commercial waste form) results

969 Geochemical constraints on the microbial contamination of a hypothetical UK deep geological repository

970 | Evaluation of strategies for controlling HWVP (Hanford Waste Vitrification Plant) glass by process simulation

971 I Immobilization of krypton in a metallic matrix <Augmentation> Electron and gamma radiation

972 I Fission Product Plateout and Liftoff in the MHTGR Primary System: A Review TI <NOTE> Technical rept

973 | Chemical waste/nuclear waste disposal -- is there a difference. Waste isolation in the U.S. and elsewhere, technical programs and public communications. Vol 1 . General

974 Soil physical properties at the Las Cruces trench site

975 Soil Characterization Methods for Unsaturated Low-Level Waste Sites

976 Effects of radiolysis, radiation damage and waste/martix interaction.

977 Electrical resistivities of glass melts containing simulated SRP waste sludges TI <Augmentation> For melter design

978 I Determination of formation heterogeneity at a range of scales using novel multi-electrode resistivity scanning techniques Disposal of Radioactive Waste

979 I Vitrification of TRU wastes at Rocky Flats Plant 
WHC-SD-TD-RPT-011

Revision 0

980

Adjoint sensitivity analysis of the thermomechanical behavior of repositories Waste isolation in the U.S., technical programs and public education. Vol. 1

981 i A direct speciation of $\mathrm{Cm}$ (III) in natural aquatic systems by time resolved laser-induced fluorescence spectroscopy (TRLFS) Chemical effects in the mine structure. Proceedings TI Chemische Effekte im Grubengebaeude. Vortraege

982 I Pressure and density measurements of selected fluid-bearing zones at

- the Waste Isolation Pilot Plant (WIPP) Waste management 86. Volume 2: High-level waste

983

984

985

Effect of hot-pressing conditions on the properties of iodide sodalite Spectrophotometric determination of uranium in nuclear waste Waste characterization plan for the Hanford Site single-shell tanks. Revision 1

986 Waste characterization plan for the Hanford Site single-shell tanks

987 Progress with field investigations at Stripa

988 Research on nuclear waste isolation at Stripa: an overview. Earth Sciences Division annual report 1981

989. I Research and development related to the Nevada nuclear waste storage investigations. Progress report, July 1-September 30, 1980

990 i Development and testing of waste package backfill materials for a nuclear waste repository located in basalt

991 | Preparation and characterisation of Synroc precursor powders.

992 Accelerated irradiation testing of synroc and its constituent minerals using fast neutrons

993 Adsorption and heat transfer characteristics in krypton-85 storage cylinder filled with adsorbent

994 I Immobilization of medium-level waste at Tokai Reprocessing Plant Spectrum 186: Proceedings: Volume 1

995 Immobilization of radioactive wastes in hydrothermal synthetic rock, 3. Properties of waste form containing simulated high-level radioactive waste

996 Migration chemistry and behaviour of iodine relevant to geological disposal of radioactive wastes - a literature review with a compilation of sorption data

997 I Some reconnaissance-type electrical surveys of Timber Mountain Caldera; Nye County, Nevada

998 i Preparation and testing of hydrated cement samples for immobilization of simulated medium active waste

999 Static leach tests of simulated MLW conditioned in cement

1000 Savannah River Plant Environmental Report: Volume 2, Annual Report for 1986

1001 Fracture detection using subsurface electromagnetic techniques Rock mechanics: Proceedings of the 28th U.S. symposium

1002 The recovery of neptunium, plutonium and americium from high active waste by TRPO extraction American Chemical Society, Division of Nuclear Chemistry and Technology

1003 First phase of small diameter heater experiments in tuff TI $<$ Augmentation> NNWSI project

1004 Conceptual design of field experiments for welded-tuff rock-mechanics program 
WHC-SD-TD-RPT-011

Revision 0

1005 Summary of geochemical measurements taken in an around the G-Tunnel underground facility, NTS

1006 Geoengineering characterization of welded tuffs from laboratory and field investigations Scientific basis for Nuclear Waste Management VIII

1007 G-tunnel welded tuff mining experiment preparations

1008 Survey of microbial degradation of asphalts with notes on relationship to nuclear waste management

1009 Resolution-enhanced reflectance spectroscopy of nuclear waste glass Nuclear waste management II TI <Series/Collective> Advances im ceramics. Volume 20

1010 - Simulation of heat transfer in the unsaturated zone TI <Augmentation> Yucca Mountain Project

1011 FEHMN 1.0: Finite element heat and mass transfer code TI <Augmentation> Yucca Mountain Project

\section{SEARCH NO 2: INDIVIDUAL PHYSICAL PARAMETER}

Hanford Technical Library

Database Search Service.

11/29/93 10:12am

1 : Tank 241-A-105 Teak assessment

2 : The Yucca Mountain Project Prototype Testing Program TI <Augmentation> Yucca Mountain Project

3 : Stripa Project. Annual report 1986

4 : Thermocouple tree system installation and operation in non-leaking ferrocyanide tanks, Hanford Site, Richland, Washington

5 : WIPP waste characterization program sampling and analysis guidance manual

$6 \quad$ I Compas project stress anaTysis of HLW containers intermediate testwork

$7 \quad$ Compas project stress analysis of HLW containers: behaviour under realistic disposal conditions

8 Analyzing surface coatings in situ: High-temperature surface film analyzer developed TI Technology '90. Accomplishments in technology. transfer from DOE and its laboratories

$9 \quad$ Geotechnical Field Data and Analysis Report, July 1987--June 1988

10 Empirical pillar design methods review report: Final report

11. Single-hole permeabiity test procedure: Final draft

12 Salt Repository Project site study plan for meteorology/air quality: Revision 1

13 Low level waste management handbook series: Environmental monitoring for low level waste disposal sites

14 Lasers to detect radioactive leaks

15 Pumping test and fluid sampling report - Mansfield No. 1 (PD-4) well, Palo Duro Basin, Texas: unanalyzed data TI <Augmentation> Permian Basin, Texas

16 I Rock mass and shaft concrete lining temperature measurement procedure: Final draft 
WHC-SD-TD-RPT-011

Revision 0

17 I Report of liquid permeability measurements on rock core samples from Mansfield No. I Well, Permian Basin project

18 Geochemistry and petrology of surface samples, six boreholes and brines from the Salton Sea geothermal field: A natural analog of a nuclear waste repository in salt: Report No. 3

19 i Report of 7 iquid permeability measurements on rock core samples from Detten No. 1 Well, Permian Basin Project

20 I Boring and instrument installation DWPF salt disposal site

21 Trial storage of high-level waste cylinders in the Asse II salt mine. Final report $1977 / 1978$

22 I Permeability data base: Palo Duro Basin - Texas, Oklahoma, and New Mexico - unanalyzed data

23 I International 'Dawson' Symposium on the Physics of Plasmas

24 Thermocouple tree system installation and operation in non-leaking ferrocyanide tanks, Hanford Site, Richland, Washington. Environmental assessment

25 I Evaluation of radon emissions and potential control requirements: For the Weldon Spring Site Remedial Action Project, Weldon Spring, Missouri. Revision 2

26 I Ergebnisbericht ueber Forschungs- und Entwicklungsarbeiten 1986. (Summarizing report on research and development activities in 1986)

27 Numerical Tables on Physical and Chemical Analyses of Rhine Water 1983

28 KfK Institut fuer Material- und Festkoerperforschung. Ergebnisbericht. ueber Forschungs- und Entwicklungsarbeiten 1989. (Summarizing report on research and development activities in 1989, KfK Institute of Materials and Solid State Research)

29 Extended Abstracts. The Electrochemical Society Fall Meeting (174th) Held in Chicago, I1] inois on 9-14 October 1988. Volume 88-2

30 In-situ permeable flow sensor

31 Fusion Reactor Materials: Semiannual Progress Report for the Period Ending March 31, 1989

32 Fusion Reactor Materials Semiannual Progress Report for the Period Ending September 30, 1988

33. Hydrogeologische, geohydraulische und geothermische Untersuchungen an geplanten Standorten fuer die Endlagerung radioaktiver Abfaelle. Teilprojekt 3: Geothermik. Abschlussbericht. (Hydrogeological, geohydraulic and geothermal studies on projected sites for final storage of nuclear waste. Sub-project 3. Geothermal studies. Final report)

34 DOT-BPMD; Nonlinear Heat Transfer 2d Structure TI <NOTE> Software

35 Measurement of Low Permeabilities and of Pinpoint Hydraulic Load Variations as a Function of Depth in Crystalline Formations

36 I Heat Transfer. Investigations within Dry Spent Fuel Casks. Final Report for the Period 1 November 1981-31 March 1986

37 Results of Repository Conditions Study for Commercial and Defense High-Level Nuclear Waste and Spent Fuel Repositories in Salt

38. <English> STFLO; a finite-element code for steady-state flow in porous media

39 i <English> SWENT; a three-dimensional finite-difference code for the simulation of fluid, energy, and solute radionuclide transport 
WHC-SD-TD-RPT-011

Revision 0

40 STAFAN: a two-dimensional code for fluid flow and the interaction of fluid pressure and stress in fractured rock for repository performance assessment

41 Review of Existing Instrumentation and Evaluation of Possibilities for Research and Development of Instrumentation to Determine Future Levels of Radon at a Proposed Building Site

42 i English> MATLOC; a two-dimensional and axisymmetric nonlinear finite-element transient thermal stress analysis code for rock masses that exhibit bilinear locking behavior

43. LEnglish> VISCOT; a two-dimensional and axisymmetric nonlinear transient thermoviscoelastic and thermoviscoplastic finite-element code for modeling time-dependent viscous mechanical behavior of a rock mass

$44 \quad$ Cermets and method for making same

45 IN SITU CHARACTERIZATION OF THE HIGH-LEVEL WASTE SLUDGE AT WEST VALLEY.

46 The influence of bentonite on the permeability of sandy silts

47 Flow and tracer experiments in crystalline rocks. Results from several Swedish in situ experiments Coupled processes affecting the performance of a nuclear waste repository. Proceedings

48 I Migration in a single fracture in granitic rock Scientific basis for nuclear waste management VII TI <Series/Collective> Materials Research Society symposia proceedings, Volume 26

49 Melt refining method for uranium contaminated steels and copper Waste management 185: waste isolation in the US technical programs and public participation. Volume 3. General interest

50 Development of high-temperature UV-VIS-NIR spectroscopy for the measurement of free energies of complexation at elevated temperatures

51 Radioactive Emanations in Fumarole Gases of a Series of Volcanoes in Kamchatka

52. LEnglish> Statistical analysis of granite pore size distribution data, Lac du Bonnet Batholith, eastern Manitoba TI <French Translation> Etude par la methode statistique des donnees de la distribution du diametre des pores dans le granite, batholite du lac du Bonnet, Est du Manitoba

53 Overview of geologic and geohydrologic conditions at the Finnsjoen site and its surroundings

54 Lateritic minerals for decontamination of radionuclides

55 Neptunium migration involving oxidation-reduction reactions in engineered barriers Proceedings of the third international symposium on advanced nuclear energy research

56 Gamma-ray emission tomography examination of TMI-2 core samples

57 Establishment of new disposal capacity for the Savannah River Plant Proceedings of the eight annual DOE low-level waste management forum: Technical Session 8, Future DOE low-level waste management

58 Thermomechanische Beanspruchung der Umgebung von Waermeque 7 len unter Beruecksichtigung der Festigkeits- und Versagensgrenzen von Steinsalz. Ein Beitrag zur Endlagerung radioaktiver Abfaelle. (Thermomechanical effects in the vicinity of heat sources with consideration of the strength-to-failure limits of salt rock. A study on conditions of radioactive waste ultimate disposal) TI 〈NOTE> Diss. (Dr.-Ing) 
WHC-SD-TD-RPT-011

Revision 0

59 I Separation by Transportation in Vapor Phase of Stainless Steels Components.

60 New technique to evaluate the surface degradation of cementaneous matrix Proceedings of high level radioactive waste management

61 I Method of and apparatus for the treatment of radioactive waste water from nuclear power plants

62 Method of treating radioactive waste water

63 <English> A finite element model to predict the flow of underground contaminants due to leakage of chemical and/or radioactive material from a buried containment

64 Development of a computer program for calculation of flow velocity in the borehole and hydraulic conductivity of the formation. Final report for the period 1 July 1982-30 June 1983 TI <Augmentation> Labelled Slug Test (LST) method program

65 I Rock Property Measurements on Large-Volume Core Samples from Yucca Mountain USW GU-3/G-3 and USW G-4 Boreholes, Nevada Test Site, Nevada

66 i Dissolved helium, inert gases, radium and radon in groundwaters from the Altnabreac research site

67 Evaluating the effect of sampling and spatial correlation on ground-water travel time uncertainty coupling geostatistical, stochastic, and first order, second moment methods Geostatistical, sensitivity, and uncertainty methods for ground-water flow and radionuclide transport modeling. Proceedings

68 Filtration of gaseous effluents from a furnace for smelting contaminated metals Gaseous effluent treatment in nuclear installations. Proceedings of a European conference held in Luxembourg

69 Temperature indicating device Stress analysis of HLW containers. Compas project

71 Directory of computer codes suitable for stress analysis of HLW containers - Compas project

72 Volume calibration and instrument testing at ENEA (Italian Commission for Alternative Energy Sources) central research laboratory (Casaccia, Italy)

73 I Fission Gas and Iodine Release Measured in IFA-430 Up to 15 GWd/T UO sub 2 Burnup

74 I Dungeness ' $B$ ' Nuclear Power Station. Flow Investigations of the I.F.D. Cell and I.F.D. Scavenge Cyclone Assemblies and Efficiency Test of a Production Unit

75 Numerical simulation of drift response in rock salt resulting from the emplacement of RH-TRU (Remote Handled TRansUranic) waste in an array of horizontal long boreholes in a separate panel at the WIPP (Waste Isolation Pilot Plant)

76 INFLUENCE OF WASTEFORM PERMEABILITY ON THE RELEASE OF RADIONUCLIDES FROM A REPOSITORY.

77 NAMMU user guide

78 Validation of TEMP: A finite line heat transfer code for geologic repositories for nuclear waste

79 - <ngi ish> Residual streses and stress corrosion effects in cast stee 1 nuclear waste overpacks

80 Temperature field due to multipass welding of radioactive waste containers 
WHC-SD-TD-RPT-011

Revision 0

81 The Hydrogen Program: The present understanding of cyclic venting tanks

82 Modelling fluid flow in fractured-porous rock masses by finite-element techniques

83 I A physico-chemical characterisation technique for determining the pore-water chemistry in argillaceous rocks

84 - Calibration of mathematical models for simulation of thermal, seepage and mechanical behaviour of boom clay

85 Radiometric emanation method for monitoring morphology and porosity changes during radwaste cementation.

86 I A study of the characteristics of very deep granite: Test in underground laboratories and using boreholes Radioactive waste management and disposal

87 Techniques Used in Hydrogeological Studies and Interpretation of the Results Obtained

88 i English> Temperature and saturation effects on diffusion of carbon dioxide through tuff

89 I Preliminary site investigation for the HOCUS experiment HOCUS cruise report

90 Sequence of onboard operation HOCUS cruise report

91 Glass composition effects on the results of $M C C-1, M C C-3$ and pulsed-flow leach tests

92 Thermocouple placement and hot spots in radioactive waste tanks

93 Instrumentation concepts for nuclear waste glass melters Waste management '85: waste isolation in the US, technical programs and public education. Volume 1. Waste policies and programs, high-level waste: proceedings

94 Measure of water transfers by diffusion and permeation through materials

95 Interpretation of the WIPP-13 multipad pumping test of the Culebra Dolomite at the Waste Isolation Pilot Plant (WIPP) site

96 Evaluation of excavation effects on rock-mass permeability around the waste-handling shaft at the WIPP site Excavation response in geological repositories for radioactive waste Proceedings of an NEA Workshop

97 Development of the county database: Estimates of exposure rates and times of arrival of fallout in the ORERP Phase- 2 area. Comparison with cumulative deposition-density estimates based on analyses of retrospective and historical soil samples

$98 \quad 25$ years of actinide research at the European Institute for Transuranium Elements Fifty years with nuclear fission. Volume 1

99 Detection and speciation of transuranium elements in synthetic groundwater via pulsed-laser excitation

100 Method of removing radioactive waste from $0 i 1$ Factors affecting interaction of radiostrontium with river sediments Analysis methods for offsite transport hazards

103 In-situ air permeability measurements in mine overburden heaps National soils conference: abstracts

104 Scoping experimental analysis of factors affecting cask contamination weeping. Extended abstract

105 Falcon seminar, Winfrith Technology Centre, 27 - 28 June 1989 
WHC-SD-TD-RPT-011

Revision 0

106 Chemical composition of ground water and the locations of permeable zones in the Yucca Mountain area, Nevada <Original Series/Collective> USGS Open-File Report 83-854

107 Thermal Analysis of the WIPP (Waste Isolation Pilot Plant) in Situ Room Al DHLW (Defense High-Level Waste Container) Package Experiments

108. Fire protection measures in a repository for radioactive wastes

109 <English> Radiation dose deposition and colloid formation in a rock salt waste repository

110 Concentration of chromate ions on $V$ sub 20 sub 5 - a radioindicator sorption study (Preprint no. AR-29) International symposium on radiochemistry and radiation chemistry (Plutonium - 50 years) (held at Bombay during February 4-7, 1991): Preprints volume

111 First Atmospheric Diffusion Experiment Campaign at the Angra Site Measured Data

112 Characterization of borosilicate glass-containing Savannah River Plant radioactive waste: $M C C-1$ tests and durability in geologic repository groundwaters Geochemical behavior of disposed radioactive waste TI <Series/Collective> ACS symposium series 246

113 Test methods for selection of materials of construction for high-level radioactive waste vitrification. Revision

114 Test methods for selection of materials of construction for high-level radioactive waste vitrification Nuclear waste management II TI

<Series/Collective> Advances im ceramics. Volume 20

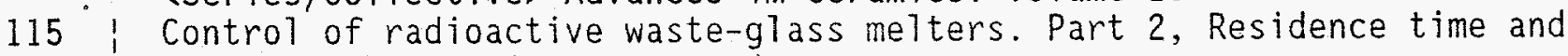
melt rate limitations

116 Control of radioactive waste-glass melters

117 Studies on neptunium(V) carbonate complexes under geologic repository conditions

118 Permeability of different materials to radon (222Rn) gas TI <NOTE> Report no. MRL 91-153(TR)

119 Drying Analysis of a Multiphase, Porous-Flow Experiment in Fractured Volcanic Tuff

120 Temperature distribution in WP-Cave when shafts are filled with sand/water mixture SKB WP-Cave project

121 Methodology for determining time-dependent mechanical properties of tuff subjected to near-field repository conditions

122 | English> Borehole gravity surveying, current instrumentation, capabilities and applications TI <French Translation> Diagraphies gravimetriques, instruments actuels, possibilites et applications

123 i Heat Source Probe for Measuring Thermal Conductivity in Waste Rock Dumps

124 | The Joint Empirical Model---an equivalent continuum model for jointed rock masses TI <Augmentation> Yucca Mountain Project

125 Numerical analyses of the G-Tunnel small-diameter heater experiments

126 Thermal Conductivity Measurement in Italian Clay Samples: Needle Probe Method

127 Application of Integral Methods to Prediction of Heat Transfer from a Nuclear Waste Repository

128 | <nglish> Distribution of downward flux in unsaturated heterogeneous hydrogeology TI <French Translation> Distribution de flux descendants en hydrogeologie en zone non saturee heterogene 
WHC-SD-TD-RPT-011

Revision 0

129 | SWISS: Sustained heated metallic melt/concrete interactions with overlying water pools

130 i Numerical model of contaminant transport through conduit-porous matrix system

131 I Shear of a clay-embedded waste canister.

132 Modelling of buffer material behaviour. Some examples of material models and performance calculations

133 I Studies of soil gas, gas generation, and shallow microbial activity at Mallard North Landfi11, Dupage County, I11 inois

134 I Miniature chemical optical fiber sensors for pH measurements

135 The HADES demonstration and pilot project on radioactive waste disposal in a clay formation

136 . <English> Grouting of fractures using oscillating pressure TI <French Translation> Injection dans des fractures a l'aide de la methode de $1 \mathrm{a}$ pression oscillante

137 Incineration method for volume reduction and disposal of transuranic waste Waste management '85: waste isolation in the US technical programs and public participation. Volume 3. General interest

138 An interim report on excavation effect studies at the Waste Isolation Pilot Plant: The delineation of the disturbed rock zone

139 Measurement of the Specific Resistance of Vitrified Highly-Active Waste

140 Overview of chemical modeling of nuclear waste glass dissolution. TI $<$ Augmentation> Yucca Mountain Project

141 Fracture Hydrology Relevant to Radionuclide Transport. Field Work in a Granite Formation in Cornwall TI <NOTE> Final rept.

142 Cornish heat transfer experiment - final report

143 Heat transfer experiment in a granite formation at Cornwall

144 Anwendung der Tieftemperatur- und Filtertechnik fuer die Rueckhaltung von Edelgasen, Aerosolen, Jod und Feststoffen am Beispiel des Abgassystems bei Leichtwasserreaktoren unter Beruecksichtigung der besonderen Anforderungen an Sicherheit, Verfuegbarkeit und

Strahlenschutz. (Use of low-temperature and filter techniques for the retention of rare gases, aerosols, iodine and solid materials taking as example the off-gas systems of light-water reactors with regard to the special requirements on safety, availability and radiation protection)

145 Magnox dissolution in carbonated water. A method for the separation and disposal of magnox from fuel element debris waste Water chemistry of nuclear reactor systems 3 vol. 1. Proceedings of an international conference organised by the British Nuclear Energy Society and co-sponsored by the Institution of Chemical Engineers and the Royal Society of Chemistry, Bournemouth, 17-21 October, 1983

146 Permeability measurements in crystalline rocks and sandstone

147 Diffusion and permeability based sorption measurements in intact rock samples

148 I Participation of the Federal Republic of Germany in the Grimsel underground rock laboratory in Switzerland: Objectives and methods of in-situ experiments in granite for radioactive waste disposal siting, design and construction of underground repositories for radioactive wastes. Proceedings of an international symposium held in Hannover, 3-7 March 1986 TI <Series/Collective> Proceedings series 
WHC-SD-TD-RPT-011

Revision 0

149 Limits of high-efficiency particulate air filter operation under high temperature conditions Proceedings of the 19th DOE/NRC nuclear air cleaning conference

150 Groundwater movement through mudrocks - measurement and interpretation

151 Comparative study of test methods for conditioned 10w- and medium-level radioactive waste. Progress report covering the period 1.1 to 31.121984

152 I HANDLING AND TRANSPORT SYSTEM USED FOR SPENT FUEL FROM THE THTR 300 MW NUCLEAR POWER STATION:

153 I On groundwater travel times in granite and gneiss Proceedings of the Canadian Nuclear Society 2. international conference on radioactive waste management

154 Estimation of Heavy Metal Concentration in FBR Reprocessing Solvent Streams by Density Measurement

155 | Bereitstellung gesicherter Sorptionsdaten fuer Technetium.

Berichtszeitraum: 1.1.1986 - 30.6.1987. Sch7ussbericht. (Collection of verified sorption data on technetium. Reported period: January 1, 1986 - June 30, 1987. Final report) Cesium chloride compatibility testing program: Final report

157 Effects of heterogeneity on actinide diffusion rates in tuffaceous rock

158 I Development of a Sanded Nonsalt Expansive Grout for Repository Sealing Application TI <NOTE> Final rept.

159 Development of a Sanded Expansive Salt Grout for Repository Sealing Application TI <NOTE> Final rept.

160 Electrical technique for in-place stabilization of contaminated soils

161 Thin Plastic Radiochromic Dye Films as Ionizing Radiation Dosimeters TI <NOTE> Final rept.

162 Measurements of / sup 137/Cs Diffusion Coefficients in an Epoxide Resin 163

164

165

166

167

168 Incineration of radioactive waste TI A system for one-line measurement Elastic properties of dry, highly porous tuffs Rock mechanics:

Proceedings of the $28 \mathrm{th}$ U.S. symposium

Spent Fuel Test-Climax mineby revisited

Thermomechanical scoping calculations for the waste package environment tests TI <Augmentation> NNWSI

Interpretation of hydraulic testing at the Weiach borehole

Glass former composition and method for immobilizing nuclear waste using the same of gaseous multicomponents Incineration conference 1990

169 Comparison of rheological evaluation techniques and turbulent flow prediction of a simulated nuclear waste melter slurry

170 I Triaxial cell and permeameter equipment and facilty safety analysis report

171 Spent Fuel Test-Climax: technical measurements data management system description and data presentation. TI <Augmentation> NNWSI program

172 Cerenkov spectroscopic assay of fission isotopes Pt. 3. A study on the influence of $\mathrm{pH}$ and sodium concentration on the uptake of / sup $137 / \mathrm{Cs}$; /sup $90 / \mathrm{Sr}$ and /sup $90 / Y$ onto zeolites Articles

173 I Method to Enhance Porosity of Micro-particles TI <NOTE> Final rept

174 Experience with high-temperature filtration of incinerator flue gases Incineration conference 1990 
WHC-SD-TD-RPT-011

Revision 0

175 Thermomechanical analysis of some proposed schemes for radioactive waste disposal Numerical methods in geomechanics

176 | Quarterly report on Defense Nuclear Facilities Safety Board Recommendation 90-7

177 Action plan for response to abnormal conditions in Hanford Site radioactive waste tanks containing ferrocyanide

178 Action plan for response to abnormal conditions in Hanford Site radioactive waste tanks containing ferrocyanide. Revision 1

179 . In situ testing and corrosion monitoring in a geological clay formation Design and instrumentation of in situ experiments in underground laboratories for radioactive waste disposal. Proceedings TI La conception et 7 'instrumentation d'experiences in situ en laboratoires souterrains pour l'evacuation des dechets radioactifs.. Comptes-rendus

180 Development and implementation of methods for mass and volume measurements in input solutions

181 Depollution of some radioactive residual waters on ceramic materials 182 Actinide separations by high pressure cation exchange - the neptunium case New separation chemistry techniques for radioactive waste and other specific applications

183 I Separation of actinides with alkylpyridinium nitrates New separation chemistry techniques for radioactive waste and other specific applications

184 - Caesium decontamination from MTR waste solution New separation chemistry techniques for radioactive waste and other specific applications

185 Application of crown-ethers to caesium and strontium removal from Marcoule reprocessing concentrate New separation chemistry techniques for radioactive waste and other specific applications

186 Highly selective and micellar extraction of uranyl and alkaline-earth cations New separation chemistry techniques for radioactive waste and other specific applications

187 The TRUEX process: a vital tool for disposal of U.S. defense nuclear waste New separation chemistry techniques for radioactive waste and other specific applications

188 Comparison between CMPO and DHDECMP for alpha decontamination of radioactive liquid waste New separation chemistry techniques for radioactive waste and other specific applications

189 Actinides removal by means of octyl (pheny 7 ) $\mathrm{N}, \mathrm{N}$-di isobutyl carbamoy 1 . methyl phosphine oxide (CMPO) sorbed on silica New separation chemistry techniques for radioactive waste and other specific applications

190 Separation of Am, Eu and Ce from liquid wastes with CMPO by extraction chromatography New separation chemistry techniques for radioactive waste and other specific applications

191 Physico-Chemical Investigations in Relation with the Tritium Circuit in Fusion Reactors

192 Time-temperature dissolution and radionuclide transport

193 In situ stress determination by the overcoring of large surface strain gauge rosettes on the walls of a raise-bored shaft at the Underground Research Laboratory 
WHC-SD-TD-RPT-011

Revision 0

Abyssal plains^ Potential sites for nuclear waste disposal Environmental geotechnology TI <Series/Collective> Volume 1 experiment

196 i Coupled stiffness-permeability analysis of a single rough surfaced fracture by the three-dimensional boundary element method Neutronics studies for the ARIES-I reactor Thermoviscoelastic stress problems by the Lanczos-Chebyshev method Verification of NAMMU using HYDROCOIN Level 1 Case 4 : transient thermal convection in a saturated permeable medium

200 Transient nonsimilarity nonlinear heat diffusion solutions

201 Thermal Calculus of Packagings for Long Lasting Fires

202 Codisposal of diminimus levels of low-level radioactive waste and sanitary waste: Final report

203 Materials Research Society Symposium on the Electrical, Optical and Magnetic Properties of Organic Solid State Materials. Held in Boston Massachusetts on November 27-December 2, 1989 TI <NOTE> Final rept

204 I Development of a new powdered resin for water purification in nuclear power plants Waste management '88 TI <Series/Collective> Volume I: Low-level. waste

205 <English> Radiochemical determination of technetium-99 in LLW by chelation with sodium diethyl dithiocarbamate ( $\mathrm{NaDDC}$ ) and extraction with chloroform

Thermal effects of electrically conductive deposits in melter Laboratory analysis of fluid flow and solute transport through a variably saturated fracture embedded in porous tuff

Repository environmental parameters and models/methodologies relevant to assessing the performance of high-jevel waste packages in basalt, tuff, and salt

209 Repository tunnel construction in deep clay formations

210 Stochastic analysis of ground water traveltime for long-term repository performance assessment Scientific basis for nuclear waste management VII TI <Series/Collective> Materials Research Society symposia proceedings, Volume 26

211 . Stochastic Groundwater Traveltime Modeling Using a Monte Carlo Technique

212 Testing nuclear-grade gas-phase iodine adsorbents

213 Method for keeping RBOF waste within EPA PH limits for nonhazardous waste

214 Colorimetric determination of $\mathrm{Fe}$ sup $2+/ \mathrm{Fe}$ sup $3+$ ratio in radioactive glasses

215 Method for making a low density polyethylene waste form for safe disposal of low level radioactive material PA Dept. of Energy AN US 6-617660

216 Analysis and evaluation of a radioactive waste package retrieved from the Atlantic Ocean Radioactive wastes and the ocean TI $<$ Series/Collective> Wastes in the ocean. Vol. 3 
WHC-SD-TD-RPT-011

Revision 0

217 Quantitative approach to exchange phenomena between low temperature hydrothermal solutions and granitic rocks: methodology and preliminary studies in the Entraygues granite Natural analogues in radioactive waste disposal. Proceedings of a symposium organised by the CEC and held in Brusse]s, BE, on 28-30 April 1987 <Original Series/Collective> Radioactive Waste Management Series

218 The CEC benchmark interclay on rheological models for clays results of pilot phase (January-June 1989) about the boom clay at Mol (B)

219 i Computer modelling of stresses in rock. Proceedings of a technical. session

220 Application of speckle metrology at a nuclear waste repository.

221. A casting and imaging technique for determining void geometry and relative permeability behavior of a single fracture specimen

222 Asse salt mine nuclear waste repository simulation experiments

223 Asse (Federal Republic of Germany) Salt Mine Nuclear Waste Repository Simulation Experiments

224 Brine migration test report: Asse Salt Mine, Federal Republic of Germany: Technical report

225 Nuclear Waste Repository Simulation Experiments (Brine Migration), Asse Mine of the Federal of Germany: Quarterly Brine Migration Data Report, July-September 1984

226 i Quarterly brine migration data report, May-September 1983: Nuclear Waste Repository simulation experiments (brine migration), Asse Mine of the Federal Republic of Germany

227 Localized corrosion of a candidate container material for high-level nuclear waste disposal.

228 i The calculated effects of isothermal boiling on tuff-water interactions

229 Analytical methods and problems for the diamides type of extractants

230 Comparisons of COBRA-SFS Calculations with Data from Simulated Sections of Unconsolidated and Consolidated BWR Spent Fuel. Final Report

231 Characterization of the subregional ground-water flow system of a potential site for a high-level nuclear waste repository

232 <English> On the diffusion of SUP 9 SUP 0 Sr from radioactive waste bituminized by the mould method

233 i Hydrological properties of Topopah Spring tuff: Laboratory measurements

234 Rheological measurements on cement grouts

235 Development of high temperature and pressure zirconia-based $\mathrm{pH}$ sensors High-level nuclear waste disposal

236 Development of high temperature and pressure $\mathrm{Eh}$ and $\mathrm{pH}$ sensing instruments scientific basis for nuclear waste management VII TI <Series/Collective> Materials Research Society symposia proceedings, Volume 26

237 Parametric study and sensitivity analysis for subsurface thermal problems.

238 Ice technology for hazardous waste management.

Post-accident sampling systems and analysis techniques Components of an overall performance assessment methodology Action $\mathrm{plan}$ for response to excessive temperature in high heat source waste tank 241-C-106 at the Hanford Site 
WHC-SD-TD-RPT-011

Revision 0

242 R7T7 glass initial dissolution rate measurements using a high-temperature Soxhlet device

243 Safety analysis related to the possible release of activated erosion dust in fusion reactors. Fusion technology 1986

244 In-situ pore-pressure measurements for a detailed geotechnical assessment of marine sediments TI State of the art Geotechnical engineering of ocean waste disposal

245 Recommendations to the NRC (Nuclear Regulatory Commission) for Review Criteria for Alternative Methods of Low-Level Radioactive. Waste Disposal. Task 2B. Earth-Mounded Concrete Bunkers TI <NOTE> Final rept.

246 i Recommendations to the NRC (Nuclear Regulatory Commission) for Review Criteria for Alternative Methods of Low-Level Radioactive Waste Disposal. Task 2A. Below-Ground Vaults TI <NOTE> Final rept.

247 I Recommendations to the NRC (Nuclear Regulatory Commission) for review criteria for alternative methods of low-level radioactive waste disposal. Task $2 a$. Below-ground vaults. Final report

248 i Recommendations to the NRC (Nuclear Regulatory Commission) for review criteria for alternative methods of low-level radioactive waste disposal. Task 2B. Earth-mounded concrete bunkers. Final report

249 Review of Materials for $\mathrm{pH}$ Sensing for Nuclear Waste Containment

250 Contribution to the Stud.y of Aerosol Aerodynamic Behaviour Development of a Diffusional and Inertial Spectrometer (SDI 2000). TI $<$ NOTE $>$ These (D. es Sci.)

251 Nevada Test Site field trip guidebook 1984

252

253 Nevada Test Site Field Trip Guidebook 1984

Review of fusion device fuel cleanup systems Fusion technology 1984. Proceedings of the thirteenth symposium. Conference centre of Villa Ponti, Varese, Italy, 24-28 September 1984. Volume 1 of 2

254

255

256 On-Line Liquid-Effluent Monitoring of. Sewage at Lawrence Livermore

257

Research of uranium tailing disposal by method of thickened disposal

Liquid discharge to sea/rivers/lakes. The solubility of TBP/OK in aqueous media National Laboratory

National Laboratory Radiation - risk - protection. Vol. 2

258 <English> IUGG Vol. 2Fluid flow in crystalline crust; detecting fractures by temperature logs TI <French Translation> Volume 2 de l'IUGG. L'ecoulement des fluides dans la croute cristalline; la detection des fractures par les logs de temperature

259 Status report: numerical modeling of ground-water flow in the Paleozoic formations, western Paradox Basin, Utah

260. Effect of surface finish on nuclear glass dissolution rate

261 Storage Characteristics of Spent HTR Fuel Elements in Transport and Storage Containers of Modular Cast Iron

262 A Analyzing transport in low permeable fractured rock using the discrete fracture network concept Safety Assessment of Radioactive Waste Repositories

263 Monte Carlo simulations of unsaturated flow through layered volcanic tuffs at Yucca Mountain, Nevada Water resources related to mining and energy - preparing for the future 
WHC-SD-TD-RPT-011

Revision 0

264 <English> An osmotic tensiometer for measuring pressure head in . unsaturated fractured rock

265 Three-Dimensional Thermal Analysis for the WIPP in Situ Test Room A2 Heater Configuration

266 Analysis of a multiphase, porous-flow imbibition experiment in fractured volcanic tuff

267 Effect of material heterogeneities on flow through porous media

268 In-Situ Tuff Water Migration/Heater Experiment: Posttest Therma 1 Analysis

269 I Computer modeling of greater confinement disposal of radioactive waste at the Nevada Test Site

270 Interim high level radioactive waste storage at the Idaho Chemical Processing Plant. Waste management 187: Waste isolation in the US, technical programs, and public education TI <Series/Collective> Volume 1 - General interest

271 Integrated instrument platform for in situ characterization of tank wastes

272 Integrated instrument platform for in situ characterization of tank wastes

273 Quarterly brine migration data report, April-June 1984: Nuclear waste repository simulation experiments (brine migration). Asse Mine of the Federal Republic of Germany

274 <English> Moisture movement in nonisothermal deformable media

275 <English> Study of excavation induced rock damage at the Grimsel undergorund rock laboratory TI <French Translation> Etude de l'endommagement de la roche du a l'excavation, au laboratoire souterrain des roches de Grimsel

276 Statistical methods for mechanistic model validation: Salt Repository Project

277 Structural analyses and design of a concrete liner that 1 imits the disturbed rock zone around underground openings in salt

278 Replacement of chlorinated materials by nonchlorinated low-halogenated materials in nuclear power plants Incineration of low level and mixed wastes: 1986

279 Alternative Waste Management Techniques for Spent Nuclear Fue1: Final Report: Continuation of Long-Term Leaching Tests at $200 \mathrm{deg} C$ and Investigation of the Influence of Iron on Leaching

280. I Identification and characterization of hydrologic properties of fractured tuff using hydraulic and tracer tests, test well USW H-4, Yucca Mountain, Nye County, Nevada

281 . Experimental Technique for Sampling Saturated Brines from Autoclaves: Application to the System $\mathrm{NaCl}-\mathrm{H} 2 \mathrm{O}$ at 200 Degree $\mathrm{C}$ and $25 \mathrm{MPa}$ : Salt Repository Project

282 Experimental technique for sampling saturated brines from autoclaves: Application to the system $\mathrm{NaCl}-\mathrm{H} / \mathrm{sub} 2 / 0$ at $200 /$ degree/C and $25 \mathrm{MPa}$ : Salt Repository Project

283 Analytical methods of heat transfer compared with numerical methods as related to nuclear waste repositories

284 <English> Theoretical approximation to transient heat conduction in nuclear waste repositories TI <French Translation> Approximation theorique de la conduction transitoire de la chaleur dans des depots de dechets nucleaires 
WHC-SD-TD-RPT-011

Revision 0

Pneumatic permeability measurements in a fractured, partially saturated environment Proceedings of workshop 5: Flow and transport through unsaturated fractured rock -- related to high-level radioactive waste disposal

Solubility of neptunium(IV) at high $\mathrm{pH}$

Role of measurement systems in burnup credit operations Waste glass melter numerical and physical modeling A method for predicting cracking in waste glass canisters Measurements of Uranium Mill Tailings Consolidation Characteristics TI <NOTE> Topical rept.

Settlement of Uranium Mill Tailings Piles: A Comparison of Analysis Techniques

Mode] assessment of protective barriers: Part 3

TEMPERATURE-MEASUREMENT OF SPUTTERED METAL DIMERS

Summary of geotechnical information in the Rattlesnake Mountain area A miniaturized sensor system for in situ robotic characterization of hazardous waste

296 Miniaturized sensor system for in situ robotic characterization of hazardous waste

297 Results of Temperature Test 6 in the Asse Salt Mine. Volume 1: Main Report. Volume 2: Appendix TI <NOTE> Topical rept.

298 Measuring low fissile content concentration in radioactive liquid waste and solid waste packages Low and intermediate level radioactive waste management <original Series/Collective> Volume 1 thermal accident testing of shipping containers in accordance with 10 CFR Part 71

300 Polymeric diffusion as applied to a radioiodine off-gas monitor 17 th DOE nuclear air cleaning conference: proceedings. Volume 2

301

302 Savannah River Technology Center. Monthly report

Untersuchung von Dichtsystemen und dichten Umschliessungen zum Transport und zur Lagerung radioaktiver Stoffe. Zwischenbericht 1986. (Investigation of sealing materials and tight enclosure systems with regard to transport and disposal of radioactive waste. Interim report 1986)

303 Review of models in available nonisothermal 2-phase flow codes TI <Augmentation> Yucca Mountation Project.

304 I Study of Gas Movements in Soil by a Nuclear Method: Geophysical Application TI <NOTE> These (D. 3e Cycle)

305 Technology update-86: Production technology and quality assurance

306 Methodology for.performing safety assessments for potential radioactive waste disposal facilities Radwaste 186: proceedings volume. Conference on the treatment and containment of radioactive waste, and its disposal in arid environments

307 I <English> A quantitative measure of model validation and its potential use for regulatory purposes. TI <English> Special issue. Validation of geo-hydrological models. I

$308 \quad 1$. The application of PIE techniques to the study of the corrosion of spent oxide fuel in deep-rock groundwaters. 2. Spent fuel degradation

309 i Hanford protective barriers program: Status of asphalt barrier studies - FY 1989 
WHC-SD-TD-RPT-011

Revision 0

310 Laboratory measurement of radionuclide sorption in solid waste storage Area $6 \mathrm{so} i 1 /$ groundwater systems

311 Process monitoring system for the V-Wl vitrification plant Lectures of the 6th status report on the project for reprocessing and waste treatment on March 13 th/14th 1986

312 Effects of sorption and temperature on solute transport in unsaturated steady flow Waste management 86 . Volume 2: High-level waste

313 | Progress in development of an accelerated leach test for low-level radioactive waste forms Proceedings of the ninth annual DOE low-level waste management forum: Technical session 3, Performance assessment

314 A finite element modeling method for predicting long term corrosion rates Corrosion ' $84 \mathrm{TI}$ <Series/Collective> No. 199

315 i Hydrogeological characterization of the Stripa site Proceedings of the workshop on geological disposal of radioactive waste. In situ experiments in granite

316 A comparison of measured porosity with that inferred from isotopic data and three-dimensional flow models In-situ experiments associated with the disposal of radioactive waste

317 Decommissioning and reclamation of Beaver Lodge tailings: Evaluation of potential radionuclide and trace metal migration Management of uranium mill tailings, low-level waste and hazardous waste

318 Transport of FBR Spent Fuels

319 Accelerated test techniques for measuring SCC resistance of alloys Proceedings: 1986 workshop on advanced high-strength materials

320 Coupled deformation arid fluid-flow behavior of a natural fracture in the CSM in situ test block

321 Storage and measurement demonstration of wastes containing conditioned tritium and radium sources Waste management ' $88 \mathrm{TI}$ <Series/Collective> Volume I: Low-level waste

322 Combined natural convection and surface radiation in the annular region between a volumetrically heated inner tube and a finite conducting outer tube Proceedings of high level radioactive waste management

323 i Pretreatment of Hanford PUREX Plant first-cycle waste

324 Methodology for Computing Limiting Temperature to Control U0 sub 2 Oxidation

325 I Methodology for computing limiting temperature to control UO/sub 2/oxidation

326 Assessing the performance of engineered barriers and materials for confinement of low-level radioactive waste Proceedings of the ninth annual DOE low-level waste management forum: Technical session 3, Performance assessment

327 Laboratory measurements of the solute transport properties of samples from the Bradwe11, Elstow, Fulbeck and Killingholme site investigations

328 Environmental Restoration Program: In Situ Vitrification Intermediate Scale Sampling and Analysis Plan

329 SELECTION OF A MINIMUM FRACTURATION DENSITY AREA BY GEOSTATISTICS IN CRYSTALLINE ROCK.

330 Impact of High-Leve1-Radioactive Wastes thermal output on repository design 
WHC-SD-TD-RPT-011

Revision 0

331 Climatological summary of wind and temperature data for the Hanford Meteorology Monitoring Network

332 I Review of Geological Criteria and Assessment Techniques Used for Site Investigations for Disposal of Radioactive Wastes in India

333 i Nondestructive testing of vitrified radioactive waste by computerized tomography TI <Original> Zerstoerungsfreie Pruefung verglaster radioaktiver Abfaelle mit Computertomographie

334 Nondestructive testing of tomography by computerized vitrified radioactive waste.

335 I FTRANS; Radionuclide Transport Fractured Rock TI <NOTE> Software

336 VISCOT; Rock Mass Viscous Mechanical Behavior TI <NOTE> Software

MATLOC; Thermal Stress Bilinear Locking Rock TI <NOTE> Software UTAH2; Thermoplastic Response Anisotropic Rock TI <NOTE> Software MARS high temperature blanket

340

341

Cataclastic effects in rock salt laboratory and in situ measurements A comprehensive upgrade of LLNL's (Lawrence Livermore National

Laboratory's) wastewater control program

342 High-temperature spectroscopy for nuclear waste applications Second international conference on methods and applications of

radioanalytical chemistry. Abstracts

343 Use of chaotic and random vibrations to generate high frequency test inputs. Part 1 , the system

344

345

346

347

348

349

Thermal measurements in large pool fires.

Thermal Measurements in a Series of Large Pool Fires

Dissolution of ThO sub 2 , vo sub 2 and PuO sub 2 in Nitric Acid An irradiation facility for radiation damage investigations

TITAN-I fusion-power-core engineering The TITAN reversed-field-pinch fusion reactor study. Final report, 1990: Volume 3, TITAN-1 fusion power core

350

GWHRT - A Finite Element Solution to the Coupled Ground Water Flow and Heat Transport Problem in Three Dimensions

350 Tracer Investigation of the Atmospheric Dispersion in the Dyrnaes Valley, Greenland. A Study under the Uranium Project, Performed by Risoe National Laboratory and the Air Pollution Laboratory of the National Agency of Environmental Protection

351 <English> 3D thermal stress analysis of WIPP Room T RU TRU experiments TI <French Translation> Analyse par un modele tridensionnel des contraintes thermiques resultant des experiences RH TRU dans le sallet du site WIPP

352 Wet abrasive particle impact cleaning as a nuclear decontamination technique Proceedings of the international meeting on nuclear and hazardous waste management

353 I Etude de l'extraction et de la purification de l'americium et des actinides trivalents contenus dans des effluents sur une installation fonctionnant a partir du principe des membranes liquides supportees (MLS). (Study of the extraction and the purification of americium and trivalent actinides contained in effluents with supported liquid membranes) 
357 In-Situ Permeability Measurements in the Bedrock Surrounding Underground Cavities, Using the Example of Konrad Mine

358 In situ-Permeabilitaetsmessungen im Gebirge des ausbruchnahen Bereiches von Einlagerungshohlraeumen am Beispiel der Schachtanlage Konrad. (In-situ permeability measurements in the bedrock surrounding underground cavities, using th example of Konrad mine)

359 . Electrical power supply and controls for a remotely operated glass melter for nuclear waste

360 i Commercial Nuclear Waste Research and Development Program. Quarterly report, Apri]-June 1984

361 I Proof-of-principle measurements for an NDA-based core discharge monitor

362 Tennessee's. East Fork Poplar Creek: A biological monitoring and abatement program

363 | <English> Pillar design for mines in saltrock. II TI <French Translation> Calcul des piliers pour les mines de sel II

364 Progress report of the $600 \mathrm{~m}$ borehole project of the CEC programme on management and storage of radioactive waste

365 Evaluation of the experiments with the variable pressure device

366 Drilling and Coring Methods That Minimize the Disturbance of Cuttings, Core, and Rock Formation in the Unsaturated Zone, Yucca Mountain, Nevada

Tank farm surveillance and waste status summary report for August 1990 Tank farm surveillance and waste status report for December 1990 Tank farm surveillance and waste status summary report for November 1990

Tank farm surveillance and waste status summary for October 1990 Tank farm surveillance and waste status summary for September 1990 Tank farm surveillance and waste status summary report for July 1990 Measurement of sup $222 \mathrm{Rn}$ and Its Relationship to Environmental Variables: Factors Controlling Indoor Radon: Final Report for the Contract Period June 1, 1982 to May 31, 1985

374 | <nglish> Trace metal migration transport with ion exchange for multi-components and multi-substrates with application to radium transport TI <French Translation> Le transport par migration des metaux en traces avec echange d'ion pour elements multiples et substrats multiples avec application au transport du radium

375 Dresden-1 chemical cleaning results of chemical and radiation measurements Proceedings of the technical symposium of Corrosion 86

376 <English> Transport of gases in concrete barriers

377 Uncertainties in predicting dust lofting: A review of available Titerature

378 Beanspruchungszustaende bei grossen Verformungen des Salzgebirges. (Load conditions induced by Targe-size deformation of the salt rock) TI <NOTE> Diss. (Dr.-Ing)

379 Effects of fuel burn-up and cooling periods on thermal responses in a respository for spent nuclear fuels

380 Numerical studies of heat transfer and gas migration processes in relation to in situ vitrification

381 Leaching studies of sphene ceramics containing substituted radionuclides 
WHC-SD-TD-RPT-011

Revision 0

382 Environmental corrections for a neutron-induced gamma-ray spectroscopy logging system in an air-filled borehole. Revision 1

383 Development of an in situ method to define the rheological properties of slurries and sludges stored in underground tanks

$384^{\circ}$ Improving feed slurry rheology by colloidal techniques

385 Defense waste processing facility at Savannah River Plant. Instrument and power jumpers

386 Flow measurement and control in the defense waste process

387 A three-dimensional finite element analysis of the HAW test field with two heated holes

388. I Investigation of the porosity of rocks. Impregnation with (sup 14) C-polymethylmethacrylate (PMMA), a new technique

389. Modeling of time-variant concrete properties at elevated temperatures

390 Seismic transmission measurements in salt Design and instrumentation of in situ experiments in underground laboratories for radioactive waste disposa7. Proceedings TI La conception et l'instrumentation d'experiences in situ en laboratoires souterrains pour l'evacuation des dechets radioactifs.. Comptes-rendus

391 Verification of NAMMU using HYDROCOIN

392 Coupled groundwater flow and solute transport with fluid density strongly dependent upon concentration

393 Geochemische Vorgaenge bei der Flutung des Kalisalzbergwerkes Hope. Abschlussbericht des Teilvorhabens Geochemie des FE-Vorhabens Hope. Untersuchungen endlagerrelevanter Vorgaenge vor, waehrend und nach der Flutung des Kalisalzbergwerkes Hope. (Geochemical processes observed during the flooding of the Hope potash salt mine. Final report of partial project 'geochemistry' of $R$ and $D$ project Hope. Examinations of processes relevant to final storage prior, during and after the flooding of the Hope potash salt mine)

394 Areal power density: A preliminary examination of underground heat transfer in a potential Yucca Mountain repository and recommendations for thermal design approaches TI <Augmentation> YUCCA MOUNTAIN PROJECT

395 < English> Field measurements in a multiple heater test to study the thermal and thermomechanical response of rock salt

396 i <English> Calculation and measurement of stress changes induced in a single-heater test in rock salt.

397 Development of Mathematical Models from the Results of Laboratory Tests to Describe the Material Behavior of Rock Salt and Its

Dependence on Time and Temperature Together with Calculations Based on Continuum Mechanics Using the Method of Finite Elements

398 Korrosion von Eisen und Stahl in heissen Salzlaugen. Schlussbericht. (Corrosion of iron and steel in hot salt brines. Final report)

399 A comparison of measurements and calculations for the Stripa validation drift inflow experiment

400. Bench-scale magnetic separation of Department of Energy wastes

401 Summary of the Report of the Senior Committee on Environmenta?, Safety, and Economic Aspects of Magnetic Fusion Energy

402 I Unsaturated zone moisture and vapor movement induced by temperature variations in asphalt barrier field lysimeters

403 Geologic mapping of the air intake shaft at the Waste Isolation Pilot Plant 
WHC-SD-TD-RPT-011

Revision 0

404 Benchmark Calculations with Code SWIFT to Check the Numercial Accuracy by Modelling the Groundwater Flow in a Fractured Permeable Medium. HYDROCOIN, Leve1 1 , Case 1

405 Permeability of grouted fractures in granite.

406 The SRES (Strontium Extraction) process American Chemical Society, Division of Nuclear Chemistry and Technology

407 i English> Numerical computation of thermally induced fluid flow in underground top loading nuclear waste disposal chambers

408 Scoping the monitoring instrumentation to meet repository design and construction needs Dynamic analysis and design considerations for high-level nuclear waste repositories

409 Interpretation of in-situ pressure and flow measurements of the Salado Formation at the Waste Isolation Pilot Plant

410 The tube-wave method of estimating in-situ rock fracture permeability in fluid-filled boreholes

411 Electrochemical evaluation of solid state $\mathrm{pH}$ sensors for nuclear waste containment

412 . Active waste disposal monitoring at the Radioactive Waste Management Complex, Idaho National Engineering Laboratory

413 Data acquisition system for monitoring nuclear waste vitrification

414 Results and conclusions from rock mechanics/hydrology investigations: CSM/ONWI test site Proceedings of the workshop on geological disposal of radioactive waste. In situ experiments in granite

415 I VAM2D - Variable Saturated Analysis Model in Two Dimensions. Version 5.2 with Hysteresis and Chained Decay Transport. Documentation and User's Guide TI <NOTE> Technical rept. 29 Sep 89-31 Ju1 91

416 <English> Mathematical modeling of fluid flow and contaminant transport in fractured aquifers

417 I Methods for the shipboard determination of dissolved iron and manganese in samples of sediment interstitial water

418 Plutonium diffusivity in compacted bentonite

419 CASKETSS: A Computer Code System for Thermal and Structural Anatysis of Nuclear Fuel Shipping Casks

420 TRUMP3-JR: a Finite Difference Computer Program for Nonlinear Heat Conduction Problems

421 Modelling of gas release from a nuclear waste repository Gas generation and release from radioactive waste repositories

422 Quantification and Uncertainty Analysis of Source Terms for Severe Accidents in Light Water Reactors (QUASAR). Part 2. Sensitivity Analysis Techniques

423 I Inic strength effect on solubility of $\mathrm{Np}(\mathrm{V})$ hydroxide and migration behavior of $\mathrm{Np}(\mathrm{V})$ in the presence of $\mathrm{Fe}$ (III) particles Proceedings of the third international symposium on advanced nuclear energy research

424. Rock/water interaction study in deep crystalline rocks using isotopic and uranium series radionuclide techniques

425 I Extension to unsaturated flow of the finite-element program NAMMU for coupled heat and groundwater flow

426 Coupled transport processes in semipermeable media. Part 2, Numerical method and results

427 Investigations of Sensitivity and Uncertainty in Some Hydrologic Models of Yucca Mountain and Vicinity

428 Diffusion of ion-exchanging electrolytes in montmorillonite gels 
429 Thermo-mechanical behaviour of a salt dome with a heat-generating waste repository TI <Augmentation> TASTE code and GOLIA code

430 control the vertical component of groundwater movement

Task plan for test of PRBT prototypic liquid sampler TI <Augmentation> Precipitate Reactor Bottom Tank (PRBT)

437 Task plan for test of PRBT prototypic liquid sampler. Revision 1

438 Borehole closure and test zone volume determination program for brine-permeability test results within the Waste Isolation Pilot Plant underground facility

439 I Postirradiation examination results from the LP-FP-2 center fuel module

440 Single continuum approximation of the solute transport in fractured porous media.

441 Investigation of the Migration of Harmful Organic Substances Through Mineral Seals by Means of Radioactive Tracers. Final Report

442 I Study of a Large Rapid Ashing Apparatus and a Rapid Dry Ashing Method for Biological Samples and Its Application

443 Quality assessment and testing methods in radioactive waste management apply in the 'Boris Kidric' TI Institute of Nuclear Sciences-Vinca Environmental consequences of hazardous waste disposal. Vol. 2 <0riginal Series/Collective> Ds

444 I Thermal performance of a buried nuclear waste storage container storing a hybrid mix of PWR and BWR spent fuel rods. Revision 1

445 Thermal performance of a buried nuclear waste storage container storing a hybrid mix of PWR and BWR spent fuel rods

446 : Thermal calculations pertaining to a proposed Yucca Mountain nuclear waste repository

447 Computer modeling of fluid flow and combustion in the ISV (In Situ Vitrification) confinement hood

448 Computer modeling of fluid flow and combustion in the ISV confinement hood

449 In Situ Tuff Water Migration/Heater Experiment. Final Report

450 <English> Distribution coefficients for strontium and cesium in overburden at a storage area for low-level radioactive waste TI <French Translation> Coefficients de distribution du strontium et du cesium en surcharge dans les bassins de stockage de dechets faiblement radioactifs

451 Development and evaluation of a tracer-injection hydrothermal technique for studies of waste package interactions Scientific basis for Nuclear Waste Management $X$

452 Integration of interpretation results of tracer tests performed in the Culebra dolomite at the Waste Isolation Pilot Plant site

453 Subterranean burial of spent ionizing radiation sources

454 Manufacture of electron, beam irradiation vessel and its characteristics 
WHC-SD-TD-RPT-011

Revision 0

455 Design management and stress analysis of a circular rock tunnel for storage of spent nuclear fuel

456 Formalism to generate probability distributions for performance-assessment modeling

457 Analysis of well test data from selected intervais in Leuggern deep borehole. Verification and application of PTST method

458 Prematurely terminated slug tests

459 Detecting Buried Radium Contamination Using Soil-Gas and Surface-Flux Radon Meaurements

460 I Si-C applications Silicon. Suppl. Vol. B3. System Si-C. SiC: Natural occurrence. Preparation and manufacturing chemistry. Special forms. Manufacture. Electrochemical properties. Chemical reactions. Applications. Ternary and higher systems with $S i$ and $C$

461 STEADY STATE FLUID FLOW THROUGH A POROUS MATERIAL BETWEEN TWO INFINITE PLATES MAINTAINED AT DIFFERENT TEMPERATURES.

462 I Air permeability measurements of the unsaturated Bandelier Tuff near Los Alamos, New Mexico.

463 Interpretation of the convergent-flow tracer tests conducted in the Culebra dolomite at the $\mathrm{H}-3$ and $\mathrm{H}-4$ hydropads at the Waste Isolation Pilot Plant (WIPP) site

464 Double-porosity tracer-test analysis for interpretation of the fracture characteristics of a Dolomite formation

465 I Measurements in Large JP-4 Pool Fires

466

467

468 Solubility experiments for the Nevada Nuclear Waste Storage Investigations Project

469 Low-temperature preparation of pyrolytic carbon Emergent process methods for high-technology ceramics

470 I Experimental and Theoretical Investigation of Effects Occurring During the Cooling of Technical HLW (High Level Waste) Glass Products

471 Experimentelle und theoretische Untersuchung der Vorgaenge beim Abkuehlen von technischen HAW-Glasprodukten TI <French Translation> Etude theorique et experimentale sur les effets observes au cours du refroidissement de produits vitreux techniques HLW TI <English Translation> Experimental and theoretical investigation on effects occuring during the cooling technical HLW glass products

472 Experimentelle und theoretische Untersuchung der Vorgaenge beim Abkuehlen von technischen HAW-Glasprodukten. (Experimental and theoretical investigation of effects occurring during the cooling of technical HLW glass products)

473 Temperature history for canistered fuel lag storage areas during the loss of cooling air at the receiving and handling building of the MRS Facility

474 <English> Flow and nuclide transport in fractured media: the importance of the flow-wetted surface for radionuclide migration TI $<$ English> Migration 91

475. <English> Study of porosity and migration pathways in crystalline rock by impregnation with SUP 1 SUP 4 C-polymethylmethacrylate TI <English> Migration 91 
WHC-SD-TD-RPT-011

Revision 0

476 <English> A study of the effects of an alkaline plume from a cementitious repository on geological materials TI <English> Migration 91

477 2D-SEEP computer code user's manual

478 Power fluidics for nuclear and process plant safety and control

479 Technique to investigate the mechanism of uniform corrosion in the presence of a semi-permeable membrane

480 I An evaluation of the use of mercury porosimetry in calculating hydrologic properties of tuffs from Yucca Mountain, Nevada

481 <English> Gas pulse test. A new test method for low permeability formations TI <French Translation> Gas pulse test. Une methode nouvelle pour la mesure des faibles permeabilites

482 Erfahrungen bei Durchlaufsaeulen-Versuchen mit (14) C. (Report on once-through column experiments with carbon-14)

483 I A Lagrangian reactive transport simulator with successive paths and stationary-states: Concepts, implementation and verification

484 On the reliability of computer predictions of the geomechanical behaviour of rock-salt

485 i Progress report on project COSA Excavation response in geological repositories for radioactive waste Proceedings of an NEA Workshop

486 Petrophysical characteristics of basalt in the vadose zone, Idaho National Engineering Laboratory, Eastern Snake River P1ain, Idaho

487 Instrumentation and computational techniques and resulting geostatistical characterization of INEL vadose zone basalt

Waste management modeling using reservoir characterization techniques Proceedings of the 1991 SPE annual technical conference and exhibition Buffer Mass Test - Thermal Calculations for the High Temperature Test A method for examining ground water flow and solute transport around a repository

Development of Reinstrumenting Technique of Fuel Rods with Pressure Gages. In and out-of-Pile Characteristics of Developed Fission Gas Pressure Gages

Hydrogeologische, geohydraulische und geothermische Untersuchungen an geplanten Standorten fuer die Endlagerung radioaktiver Abfaelle. T. 3. Geothermik. Abschlussbericht. (Hydrogeological, geohydraulic and geothermal studies in projected final storage sites for radioactive waste. Pt. 3. Geothermal studies. Final Report)

Final Improvement of Computer Codes to Study Temperature Determination

494 Measurement of HTO permeation rates through various candidate disposable -plastic-suit materials. Report No. 90-232-K

495 Swedish studies of high-level waste disposal in crystalline rock Radwaste 186: proceedings volume. Conference on the treatment and containment of radioactive waste, and its disposal in arid environments

496 I Spezielle Radonmessungen. Abschlussbericht (Special Radon Measurements. Final Report)

497 Field technique to measure the tortuosity and sorption-affected porosity for gaseous diffusion of materials in the unsaturated zone with experimental results from near Barnwel1, South Carolina

498 Iridium oxide thin-film stability in high-temperature corrosive solutions 
WHC-SD-TD-RPT-011

Revision 0

499 Assessment of uncertainties in measurement of $\mathrm{pH}$ in hostile environments characteristic of nuclear repositories

500 Waste Isolation Pilot Plant brine field $\mathrm{pH}$ measurements: Technique and interpretation

501 I Near-surface heater test results: environmental implications for the disposal of high level nuclear waste

502 I Solubility data for U(VI) hydroxide and $N p$ (IV) hydrous oxide: application of MCC-3 methodology Scientific basis for Nuclear Waste Management VIII

503 I Zur Berechnung dreidimensionaler Spannungs-und Verformungszustaende fuer Hohlraeume im Salzgebirge. (Computation of three-dimensional stress and deformation states for caverns in salt deposits) TI <NOTE> Diss. (Dr. - Ing)

504 In situ-investigations in salt formations Radioactive waste management and disposal

505 Cooling and devitrification in a canister of simulated nuclear waste glass

506 In-situ experiments in fractured granite Proceedings of the Canadian Nuclear Society 2. international conference on radioactive waste management

507 Method for permanently storing radioactive ion exchanger resins

508 Mooring operations Subseabed Disposal Project annual report, FY85 to termination of project: Physical Oceanography and Water Column Geochemistry Studies, October 1984 through May 1986 TI <Augmentation> Nares Abyssal Plain: Nares II Oceanographic Mission

509 I Thermal Property and Density Measurements of Samples Taken from Drilling Cores from Potential Geologic Media

510 Endeavor cruise EN-121, Leg II, September 18-October 1, 1984. Nares Abyssal Plain

511 i Rheology of rock-salt and its application for radioactive waste disposal purposes Proceedings of the international symposium on engineering in complex rock formations

512 <English> Geotechnical investigation methodes for rock salt TI <French Translation> Methodes d'etude geotechnique des roches salines

513 Modeling the steady-state ISV process: A 3-D finite element analysis of coupled thermal-electric fields

514 Scaling considerations for modeling the in situ vitrification process

515 <English> 3. Engineering geological methods for proving the barrier efficiency and stabilite of the host rock of a radioactive waste repository. TI <French Translation> 3. Methodes geotechniques pour prouver 7 'efficacite de barriere et la stabilite de la roche hote d'un site de stockage de dechets radioactifs

516 | <English> Engineering geological methods for proving the barrier efficiency and stability of the host rock of a radioactive waste repository $T I$ <French Translation> Les methodes geotechniques pour prouver la fiabilite des barrieres et la stabilite des roches encaissantes d'un site de stockage pour dechets radioactifs

517 MAGNUM2D

518 Room 209 excavation response test in the underground research laboratory Excavation response in geological repositories for radioactive waste Proceedings of an NEA Workshop 
WHC-SD-TD-RPT-011

Revision 0

519 Metal toxicity evaluation of Savannah River Plant saltstone comparison of EP and TCLP test results

520 - Metal Toxicity Evaluation of Savannah River Plant Saltstone Comparison of EP (Extraction Procedure) and TCLP (Toxicity Characterization Leaching Procedure) Test Results

521 Q Qualification of fission gas release data from Task 2 rods. High Burnup Effects Program: Final report TI <NOTE> Progress rept

522 i Probing the Hanford radioactive waste tanks with geophysical techniques

523 Recent developments in the conceptual geologic and hydrologic understanding of the WIPP site, Southeastern New Mexico Waste management '87: Waste isolation in the US, technical programs, and public education TI <Series/Collective> Volume 2 - High-level waste

524 Container for enclosing radioactive waste and a method for treating waste enclosed in the container

525 I Microwave measurements of water vapor partial pressure at temperatures up to 350 degrees $C$

526 Current status of glass leaching studies in France

527 Laboratory measurements of the hydrofracturing tensile strength of two large URL rock samples TI <NOTE> Report no. MRL 91-035(TR)

528 i English> Removal. of SUP 1 SUP 3 SUP $7 \mathrm{CS}$ and SUP 6 SUP 0 Co from real radioactive waste solution by precipitation-flocculation method

529 I Determination of Radionuclide Concentrations of $U$ and Th in Unprocessed Soil Samples TI <NOTE> Thesis (Ph.D.)

530 Estimating porosity and dispersivity of a fissured dolomitic aquifer with a two-well, recirculating tracer test using simultaneous tritium and bromide labels

531 Chemical study on the separation and purification of promethium-147 Articles

532 I Computational method for thermoviscoelasticity with application to rock mechanics TI <Augmentation>Ph. D. Thesis

533 i Theoretical evaluation of consolidated rod temperature in spent fuel storage canister Heat transfer problems in nuclear waste management TI <Series/Collective> HTD - Vol . 67

534 I K[sub d] measurements of activation, fission and heavy elements in water/solid phase systems

535 I Diffusivity and porosity studies in rock matrix: The effect of salinity. Research note

536 Tank 101-SY flammable gas mitigation test project plan

537 Sea Salt Aerosol, Atmospheric Radon and Meteorological Observations in the Western South At7antic Ocean (February 1981) TI <NOTE> Memorandum rept.

538 Geohydrological appraisal of the Vaalputs radioactive waste disposal facility in Namaqualand, South Africa

539 I Field Manual for Geohydrological Sampling as Applied to the Radioactive Waste Disposal Program

540 Moderate temperature zeolitic alternation in a cooling pyroclastic deposit TI <Augmentation> NNWSI

541 I Radiochemical investigation of the partition and sorption of lead in groundwater/sediment systems

542 A Analytical models for C-14 transport in a partialiy saturated, fractured, porous media 
WHC-SD-TD-RPT-011

Revision 0

543 Release and transport of gaseous C -14 from a nuclear waste repository in an unsaturated medium

544 i A methodology to predict the uniformity of double-shell waste slurries based on mixer pump operation

545 . Tests of absorbents and solidification techniques for oil wastes

546 Temperature measurements from the prototype engineered barrier system field test

547 Technical basis and programmatic requirements for Engineered Barrier System Field Tests

548 Hydrological properties of Topopah Spring tuff under a thermal gradient. Laboratory results.

549 Temperature measurements from a horizontal heater test in G-Tunnel

550 Pilot-scale in situ vitrification at Arnold Engineering Development Center, Arnold AFB, TN

551 Thermal analysis of the modified Hallum Nuclear Power Facility cask using experimentally obtained thermal boundary conditions corresponding to an engulfing open pool fire

552 Hydrologic characterization of fractured rocks: An interdisciplinary methodology

553 Effective porosities of basalt: A technical basis for values and probability distributions used in preliminary performance assessments

554 THERMAL ANALYSIS OF THE HEAT EXCHANGER FOR A SPENT NUCLEAR FUEL STORAGE POOL.

555 COSA II Further benchmark exercises to compare geomechanical computer codes for salt

556 Instrumented Leach Column for the Study of Sulphide Oxidation in Waste Heaps

557 Test plan: Air Intake Shaft Performance Tests

.558 Control of water infiltration at humid area shallow land burial facilities

559 General corrosion studies of candidate container materials for the Basalt Waste Isolation Project High-level nuclear waste disposal

560 I Package characterization by laboratory leaching and diffusion experiments using radionuclides Scientific basis for nuclear waste management XII <Original Series/Collective> Materials Research Society symposium proceedings. Volume 127

561 A method for determining the oxidation state of uranium at concentration as low as 10/sup -10/M Scientific basis for nuclear waste management XII <0riginal Series/Collective> Materials Research Society symposium proceedings. Volume 127

562 Thermochemical comparison of the systems Re-0 and Tc-0 Scientific basis for nuclear waste management XII <Original Series/Collective> Materials Research Society symposium proceedings. Volume 127

563 Alteration of basaltic glass in Iceland as a natural analogue for nuclear waste glasses TI Geochemical modelling with DISSOL Scientific basis for nuclear waste management XII <Original Series/Collective> Materials Research Society symposium proceedings. Volume 127

564 In-situ stress measurements - results of experiments performed at the ASSE salt mine - Federal Republic of Germany Scientific basis for nuclear waste management XII <0riginal Series/Collective> Materials Research Society symposium proceedings. Volume 127 
WHC-SD-TD-RPT-011

Revision 0

Validation of the SKBUI uranium thermodynamic data base for its use in geochemical calculations with EQ3/6 Scientific basis for nuclear waste management XII <0riginal Series/Collective> Materials Research Society symposium proceedings. Volume 127

566 I Thin-layer mixed-potential model for the corrosion of high-level nuclear waste canisters

567 Site characterization plan: Conceptual design report: Volume 5, Appendices P-R: Nevada Nuclear Waste Storage Investigations Project TI <Augmentation> NNWSI

568 I Site characterization plan: Conceptual design report, Volume 2: Chapters 4-9: Nevada Nuclear Waste Storage Investigations Project TI <Augmentation> Contains glossary

569 Site characterization plan: Conceptual design report: Volume 6, Drawing portfolio: Nevada Nuclear Waste Storage Investigations Project TI <Augmentation> NNWSI

570 I Site characterization plan: Conceptual design report: Volume 4, Appendices F-0: Nevada Nuclear Waste Storage Investigations Project TI <Augmentation> NNWSI

571 Site characterization plan: Conceptual design report, Volume 3: Appendices A-E: Nevada Nuclear Waste Storage Investigations Project TI <Augmentation> NNWSI

572 Long term leach behavior of West Valley HLW glasses Spectrum '86: Proceedings: Volume 1

573 I EFFECTS OF HEAT TRANSFER FROM A HOT PENETRATOR INSTALLED IN THE OCEAN BED.

574 OCEAN DISPOSAL OF HIGH LEVEL RADIOACTIVE WASTE PROGRESS REPORT OCTOBER 1982-SEPTEMBER 1983. CENTRIFUGE MODELLING OF HEAT TRANSFER AROUND CANISTERS INSTALLED IN SUBMERGED KAOLIN. PART 2.

575 I Advanced techniques for analytic liquid wastes management in the Rokkasho reprocessing plant

576 i Measurement of Tritium Permeation Through Resistant Materials Near Room Temperature

577 Infrared imaging systems for the ferrocyanide waste tanks at the US Department of Energy's Hanford Site

578 I Shear wave experiments at the US site at the Grimsel laboratory

579 I The application of vertical seismic profiling and cross-hole tomographic imaging for fracture characterization at Yucca Mountain Nuclear waste packaging module On-Line Uranium Determination Using Remote Fiber Fluorimetry CONDIMENT: Synthese generale des differentes versions. (CONDIMENT: General synthesis of different versions)

Europium removal with a mineral mixture

Fallout Fractionation in Silicate Soils TI <NOTE> Doctoral thesis, Aug 80-Ju1 83

588 i A method to evaluate the maximum allowable temperature of spent fuel in dry storage during a postulated accident 
WHC-SD-TD-RPT-011

Revision 0

589 I Comparison of HYDRA-II Predictions to Temperature Data from Consolidated and Unconsolidated Model Spent Fuel Assemblies

590 An interim evaluation of the thermal stability of Cu/sub $0.67 / \mathrm{Y} / \mathrm{sub}$ $0.25 / \mathrm{Kr} / \mathrm{sub} 0.08 /$ sputter deposits

591 Results of field testing of waste forms using lysimeters

592 TMI-2 EPICOR-II Resin/Liner Investigation: Low-level waste data base development program for fiscal year 1989

593 Incentives for the use of depleted uranium alloys as transport cask containment structure

594 NO[sub $x]$ abatement pilot plant 90-day test results report

595 An electrochemical approach to predicting corrosion performance of container materials TI <Augmentation> Yucca Mountain Project

596 i Demonstration of a risk-based approach to high-level waste repository evaluation, Phase 2

597 Probabilistic approach to unsaturated seepage analysis Management of uranium mill tailings, low-level waste, and hazardous waste

598 The geology of the Nevada Test Site and surrounding area: A field trip for the 28th International Geological Congress

599 i Geology of the Nevada Test Site and surrounding area: A field trip for the 28th International Geological Congress

600.1 Testing and cobra-SFS analysis of the VSC-17 ventilated concrete, spent fuel storage cask Proceedings of high level radioactive waste management

601 Expected Near-Field Thermal Performance for Nuclear Waste Repositories at Potential Salt Sites: Technical Report

602 Method of recovering hazardous waste from phenolic resin filters

603 Chemical precipitation of caesium from simulated medium active waste with hexacyanocobaltate(III) salts

604 A model for the viscosity of multicomponent glass melts Ceramic transactions

605 Standardized test methods for use in waste compliance testing in the Department of Energy's. waste acceptance process Waste management '87: Waste isolation in the US, technical programs, and public education TI <Series/Callective> Volume 2 - High-level waste

606 Investigations into the coupled fluid flow and mechanical creep closure behavior of waste disposal rooms in bedded salt Gas generation and release from radioactive waste repositories

607 662-E solid waste silo-plug lifting analysis

608 Test methods to predict long-term corrosion of container materials in repositories Scientific basis for Nuclear Waste Management VIII

609 Fiber-optic pH sensor for in-situ applications

610 Survey of techniques for corrosion monitoring

611 (In-Situ Heat Transfer Experiment (ISHTE): Final report on contract 52-5769

612 Liquid abrasive decontamination: a volume reduction technique at the R.E. Ginna Station

613 I Ion exchangers in radioactive waste management : Part II. Radiotracer studies on adsorption of barium ions on sodium titanate

614 Ion exchangers in radioactive waste management: Pt. 5 TI A case of efficient removal of $\mathrm{Ba}$ (II) from aqueous solutions by TiO[sub 2] powder - radiotracer study 
WHC-SD-TD-RPT-011

Revision 0

615 I A mathematical model of the behaviour of concrete backfill in an underground radioactive-waste repository

616 i Studies on leaching behavior of sodium borosilicate glasses by neutron activation: Effects of groundwater composition, $\mathrm{pH}$, surface area to volume ratio and temperature Second international conference on methods and applications of radioanalytical chemistry. Abstracts

617 I Waste Isolation Pilot Plant simulated RH TRU waste experiments: Data and interpretation pilot

618 WIPP waste package performance testing on simulated DHLW: Early data High-level nuclear waste disposal

619 i Test plan appendix: WIPP simulated RH TRU waste add-on tests (Additional rock mechanics and waste package performance)

620 WIPP SIMULATED DHLW TESTS: STATUS AND INITIAL IN SITU BACKFILL THERMAL CONDUCTIVITIES.

621 Heater Test 1, Climax Stock Granite, Nevada

622 Investigation of Fracture Permeability around an Underground Opening in Metamorphic Rocks

623

Monitoring the vadose zone in fractured tuff, Yucca Mountain, Nevada

625 Publications in biomedical and environmental sciences programs, 1982 Maximum-temperature calculation method for a 37-element CANDU spent-fuel bundle in an enclosure

626 Analysis of Borehole Inclusion Stress Measurement Concepts Proposed for Use in the Waste Isolation Pilot Plant (WIPP)

629 Infrared and Raman investigation of rare-earth phosphate glasses for potential use as radioactive waste forms

630 I Development of Partitioning Method: Dynamic Adsorption Characteristics of Titanic Acid and Zeolite Mixed Column for Sr and Cs Ions

631 i Critical parameters and measurement methods for post closure monitoring: A review of the state of the art and recommendations for further studies Comparison of high temperature gas particulate collectors for low level radwaste incinerator volume reduction systems Waste management '83. Vol. 1

Thermodiffusion in Glasschmelzen. Abschlussbericht (Thermal Diffusion in Glass Melts. Final Report)

Fiber-optic pH sensor for in situ applications

635 FIBEROPTIC PH SENSOR FOR INSITU APPLICATIONS

636 Advanced techniques for analytic liquid wastes management in the Rokkasho reprocessing plant Proceedings of the third international conference on nuclear fuel reprocessing and waste management, RECOD'91

637 Triaxial-and uniaxial-compression testing methods developed for extraction of pore water from unsaturated tuff, Yucca Mountain, Nevada

638 I Transient analytical temperature distributions in cylindrical packed beds volumetrically heated by radiogenic decay energy

639 Implementation of thermal/structural interactions in situ tests at the Waste Isolation Pilot Plant facility

$640 \quad 18 \mathrm{~W} / \mathrm{m}$ sup 2 mockup for defense high-level waste (Rooms $A$ ): In situ data report 
WHC-SD-TD-RPT-011

Revision 0

641 <English> Parametric analysis of performance of free-fall penetrators in deep-ocean sediments TI <French Translation> Analyse des parametres des performances des penetrateurs a chute libre dans les sediments de mer profonde

642 Determination of uranium isotopes in a complex matrix by optical spectroscopy

643 Chemistry of actinides and lanthanides. New extractants and separation methods

644 . The impact of the virgin rock temperature at Hanford on the ventilation parameters for the nuclear waste repository in basalt Proceedings of the 3 rd mine ventilation symposium

645 Measuring Methods of Matrix Diffusion. A Literature Study

646 Permeability of Shale at Elevated Temperature and Pressure: Test Methodology and Preliminary Results

647 < English> Design criteria for on underground nuclear waste repository TI < French Translation> Criteres d'etudes pour un depot de dechets nucleaires souterrain

648 Developments in the monitoring and control of Eh and $\mathrm{pH}$ conditions in hydrothermal experiments. Geochemical behavior of disposed radioactive waste TI <Series/Collective> ACS symposium series 246

649 Techniques for monitoring Eh-pH conditions in hydrothermal experiments

650 Analysis of fission gas release from U0/sub 2/ fuel during power

transients by FEMAXI-IV code Water reactor fuel behaviour and fission products release in off-normal and accident conditions

651 Geomechanical behaviour of boom clay under ambient and elevated temperature conditions

652 The Bacchus experiment at the hades underground research facility at Mol, Belgium Sealing of Radioactive Waste Repositories

653 A large scale flow and tracer experiment in granite In-situ experiments associated with the disposal of radioactive waste

654 Validation efforts in modeling partially saturated flow and transport in heterogeneous porous media - the Las Cruces trench studies Safety Assessment of Radiactive Waste Repositories

655 Sensitivity and uncertainty analyses of unsaturated flow travel time in the CHnz unit of Yucca Mountain, Nevada

656 i Thermal conductivity of seven thermal/mechanical units at Yucca Mountain, Nevada. Yucca Mountain Project

657 Calculation of heat capacities for tuffaceous units from the unsaturated zone at Yucca Mountain, Nevada. Yucca Mountain Site Characterization Project

658 Coupled fluid flow and creep analysis for room saturation of a salt repository: Parametric analysis Proceedings of the 1987 international waste management conference

659 Solidification of glass powder by a hydrothermal hot-pressing technique

660 Measurements of sediment temperatures, conductivity, and heat flow in the North Atlantic and their relevance to radioactive waste disposal

661 Coupled thermal-hydraulic-mechanical phenomena in saturated fractured porous rocks: numerical approach

662 I sup $36 \mathrm{Cl}$ studies of water movements deep within unsaturated tuffs TI <Augmentation> Yucca mountain project

663 I A capacitance-based proximity sensor for whole arm obstacle avoidance 
WHC-SD-TD-RPT-011

Revision 0

664 Implementation of initial tests in the Brine Inflow Room (Room Q) of the Waste Isolation Pilot Plant

665 Study of thermal and hydraulic phenomena accompanying a rapid power excursion on a heating channel TI <NOTE> Thesis (Ph.D)

666 In situ radionuclide transfers in the deep-sea Lysianassidae amphipod Eurythenes gryllus Interim oceanographic description of the North-East Atlantic site for the disposal of low-level radioactive waste. Volume 3

667 Distribution of Lysianassidae amphipods Eurythenes gryllus in the North-East Atlantic Interim oceanographic description of the North-East Atlantic site for the disposal of low-level radioactive waste. Volume 3

668 i The measurement of soil water tension in a hydrologic study of waste disposal site design

669 Retention properties of pressed salt for Tc, Np, Pu and Am leached from simulated HLW g.lass

670 Development of Radionuclide Migration Monitor, (1). Nondestructive Measurement of Radionuclide Concentration Distribution in Aerated Soil Sample

671 i Three dimensional coupled thermo-hydraulic-mechanical analysis code with PCG method Safety Assessment of Radioactive Waste Repositories

672 Measurements of solubilities and aqueous species related to the performance of a high-level nuclear waste repository in bedded salt: A test plan for technetium, radium, and iodine: Nuclear and Chemical Waste Program

673 I Effect of Strain Rate on the Compressive Strength of Dry and Saturated Tuff

674 I Data Summary Report for Fission Product Release Test VI-4 TI <NOTE> Technical rept

675 I Data Summary Report for Fission Product Release Test VI-5 TI <NOTE> Technical rept

676 Experimental modeling of a nuclear waste repository: Determination of convective heat transfer coefficients and drift temperature profiles Waste management 86 . Volume 2: High-level waste

677 Stress analysis of HLW containers advanced test work Compas project

678 Estimation of longevity of portland cement grout using chemical modeling techniques Scientific basis for nuclear waste management 13

679 i Durable concrete for a waste repository - Measurement of ionic ingress Scientific basis for nuclear waste management 13

680 Analytical and numerical models of transport in porous cementitious materials Scientific basis for nuclear. waste management 13

681 i Hydrothermal leaching of R7-T7 borosilicate glass Scientific basis for nuclear waste management 13

682 Modelling the in situ performance of bentonite-sand buffer Scientific basis for nuclear waste management 13

683 I Effective diffusivity of carbon dioxide and iodine through $G$ tunnel tuff Scientific basis for nuclear waste management 13 
WHC-SD-TD-RPT-011

Revision 0

684 Geotechnische und grossnumerische Untersuchungen zur direkten

Endlagerung von Brennelementen. Teilprojekt I. Thermische Simulation

der Streckenlagerung. Schlussbericht (5. Bericht). (Geotechnical and large-scale numerical studies of direct ultimate storage of fuel elements. Part project I. Thermal simulation of drift emplacement. Final report (5. report))

685 Geotechnisches Verhalten verschiedener Salzgesteine. Teilprojekt 3. In-situ-Messtechnik im Salz. Schlussbericht. (Geotechnical behavior of different salt rocks. Partial project 3 . In situ measuring techniques in salt. Final report)

686 Estimation of the Relative Permeability Distribution in Fractured Granitic Rocks by Means of Vertical Flow Measurements in the Siblingen Borehole, Switzerland TI <NOTE> Water resources investigation

687 Estimation of the relative permeability distribution in fractured granitic rocks by means of vertical flow measurements in the Siblingen borehole, Switzerland. Water Resources Investigation

688 i English> Characterization of fracture permeability with high-resolution vertical flow measurements during borehole pumping TI $<$ French Translation> La caracterisation de la permeabilite des fractures grace aux mesures haute-resolution du flux vertical au cours du pompage dans les sondages

689 I TRIO-EF a general thermal hydraulics computer code applied to the AVLIS process Laser isotope separation

690 Capillary effects of gas/liquid inclusions in waste repositories

691

692

693

694

695 <English> Ground water proves a hidden element whose time has come Performance of containment penetrations under severe accident loadings Operational and Technical Results from the Spent Fuel Test - Climax Spent fuel test - Climax: technical measurements. Interim report, Fiscal Year 1983

Application of proving-ring technology to measure thermally induced displacements in large boreholes in rock

\footnotetext{
696 A rapid method for the analysis of technetium-99 in liquid radioactive wastes Second international conference on methods and applications of radioanalytical chemistry. Abstracts

697 I Calibration of alpha-track monitors for measurement of thoron

698 Canister glass level detection by fast neutron transmission

699 Factors affecting the thermo-hydro-mechanical response of clay in the safety assessment of nuclear waste repositories Excavation response in geological repositories for radioactive waste Proceedings of an NEA Workshop

700 Method for immobilizing radioactive noble gases in zeolites

701 Thermal Response Studies. 1984 Subseabed Disposal Project annual report, October 1983-September 1984

702 Atmospheric Radon Measurements in the Antarctic Penninsula: A Prel iminary Report

703 Flow visualization and relative permeability measurements in rough-walled fractures

704 Two-phase flow visualization and relative permeability measurement in transparent replicas of rough-walled rock fractures

705 Hot test of a TALSPEAK procedure for separation of actinides and lanthanides using recirculating DTPA-lactic acid solution

706 sup $14 \mathrm{C}$ release from failed spent fuel containers
} 
WHC-SD-TD-RPT-011

Revision 0

Operation of a guarded straddle packer system

709

WIPP Horizon in Situ Permeability Measurements. Final Report

Fluid flow measurements of Test Series A and B for the Small Scale Seal Performance Tests

710 i Permeability measurements at the Waste Isolation Pilot: Plant (WIPP) Waste management 86. Volume 2: High-level waste

711 - Dispersion of contaminant during oscillatory gas-motions driven by atmospheric pressure variations

712 Test pTan: WIPP horizon in situ permeability measurements

713 <English> Measuring and modeling water imbibition into tuff TI <French Translation> Mesure et modelisation de l'imbibition d'eau dans un tuf

714 i. Separation by vapour phase transport of stainless steel constituents Decommissioning of nuclear installations TI <Augmentation> Radioactive contaminated steels

715 Immobilization of contamination by the coating of polymers on large-size waste products Decommissioning of nuclear installations

716 i Thermal techniques for surface concrete decontamination Decommissioning of nuclear installations

717 Decontamination using chemical gels, electrolytical swab, abrasives Decommissioning of nuclear installations

718 Calculation of thermodynamic properties for monomeric U(IV) hydrolysis products at $298.15 \mathrm{~K}$ and zero ionic strength

719 Effect of repository heating on dissolution of glass waste

720 Experimental measurements of the solubilities of selected long-lived fission products, activation products and actinide daughters under high pH conditions

721 Experimental measurements of the solubility of technetium under near-field conditions

722 Porosity and Focused. Dissolution of Granitic Rocks in Two Study Areas in Southern Finland: Aspects of Methodology TI <NOTE> Thes is

723 Density and Volume Measurements of Reprocessing Plant Feed

724 Rheology of glasses containing crystalline material Nuclear waste management II TI <Series/Collective> Advances im ceramics. Volume 20

725 Computer-based liquid radioactive waste control with plant emergency and generator temperature monitoring Proceedings of the ISA/86 international conference and exhibit TI <Series/Collective> Advances in instrumentation

726 i Dose rate calculations due to external irradiation from radioactively contaminated building iron Abstracts of 20. International Symposium Radiation Protection Physics

727 | Some actinide speciation using laser induced photoacoustic spectroscopy

728 Field studies and modeling of chemical processes in the unsaturated zone

729 Equilibrium sorption of cobalt, cesium, and strontium on Bandelier Tuff: analysis of alternative mathematical modeling

730 Statistical analysis of the DWPF prototypic sampler

731 Design considerations: high temperature equipment and piping of fluid bed dryer and incinerator volume reduction systems 
WHC-SD-TD-RPT-011

Revision 0

732 Cooperative LLNL/HAZWRAP project to demonstrate field-based measurement of retardation factors. I. Distribution of perchloroethylene around and within permeable zones in saturated alluvial deposits

733 Demonstration experience with an abrasive blasting technique for decontaminating concrete pads Waste management '90: Working towards a cleaner environment: Waste processing, transportation, storage and disposal, technical programs and public education. Volume 2, HLW and LLW technology: Proceedings

734 Heat removal options and temperature predictions for a vault of grouted waste Waste management '90: Working towards a cleaner environment: Waste processing, transportation, storage and disposal, technical programs and public education. Volume 2, HLW and LLW technology: Proceedings

735 Microcrack growing and long-term mechanical stability in a HLW deep-borehole repository in granite Waste processing, transportation, storage and disposal, technical programs and public education

736 i A calculation strategy for the determination of the temperature distribution in radioactive waste repositories Waste processing, transportation, storage and disposal, technical programs and public education

737 i The thermo-mechanical behavior of the underground test field TI A comparison of numerical predictions and in-situ measurement data Waste processing, transportation, storage and disposal, technical programs and public education

738 Investigations of the cooling behavior of two high active waste glass canisters by temperature distribution measurements Waste processing, transportation, storage and disposal, technical programs and public education

739 I Three dimensional modeling of the wedge pillar portion of the WIPP geomechanical evaluation (room $G$ ) in situ experiment Rock mechanics:Key to energy production

740 Determination of the tritium exhalation of radioactive wastes by means of the electret ionization chamber Abstracts of 20. International Symposium Radiation Protection Physics

741 Investigation of non-destructive techniques for the examination and quality assurance of cemented radioactive waste. Final report

742 On the time-dependent behavior of a cylindrical salt dome with a high-level waste repository

743 Measurements in the 300-metre deep dry-drilled borehole and feasibility study on the dry-drilling of a 600-metre deep borehole in the Asse II salt-mine

744 Bidirectional Draining Pore-Fluid Vessel TI <NOTE> Patent Application

745 Untersuchung der thermomechanischen Effekte im Nahbereich des Endlagerkonzepts $S L 3\left(\right.$ sup ${ }^{*}$ ). (Investigation of thermomechanical effects in the near field of a drift emplacement repository)

746 Model Calculations of Stresses and Deformations in Rock Salt in the Near Field of Heated Boreholes

747 Development of Computation Methods and Models of Thermomechanical Interaction of Salt and Storage Well Casing or Stored Wastes 
748 Development of Computer Codes to Perform Model Calculations for Thermomechanical Interaction of Rock Salt with Borehole Liners in a HLW (High Level Waste) Repository

749 Model calculations of the thermomechanical effects in the near field of a high-level radioactive waste repository

750 Buffer mass test In situ experiments in granite associated with the disposal of radioactive waste. Proceedings of the symposium TI Les experiences in situ dans du granite relatives a l'evacuation des dechets radioactifs. Compte rendu du symposium

751 I Preliminary results from the buffer mass test of phase I, Stripa project Proceedings of the workshop on geological disposal of radioactive waste. In situ experiments in granite

752 I Stripa Buffer Mass. Test instrumentation for temperature, moisture, and pressure measurements Design and instrumentation of in situ experiments in underground laboratories for radioactive waste disposal. Proceedings TI La conception et l'instrumentation d'experiences in situ en laboratories souterrains pour 1'evacuation des dechets radioactifs.. Comptes-rendus

753 I Improved method to evaluate radionuclide migration model parameters from flow-through diffusion tests in reconsolidated clay plugs

754 Experimental modelling of the near-field thermal regime in a nuclear-fuel waste disposal vault.

755 NET safety analyses and the European safety and environmental programme

756 I Steady flow in voids and closed cracks in permeable media. 1. Concentric spheres

757 Coupled heat and groundwater flow in porous rock Numerical methods in heat transfer TI <Series/Collective> Volume II

758 Dissolution kinetics of heulandite at $\mathrm{pH} \mathrm{2--12}$ and 25[degrees]C

759 Hydrothermal impact of a high-level nuclear waste repository Rock mechanics: Proceedings of the 28th U.S. symposium

760 Possible relation between sonic velocity measured at the edge of a large borehole and shear failure Fourth symposium on containment of underground nuclear explosions. Proceedings: Volume 2

761 i Prototype heater test of the environment around a simulated waste package

762 In situ changes in the moisture content of heated, welded tuff based on thermal neutron measurements. TI <Augmentation> YUCCA MOUNTAIN PROJECT:A1

763 < English> Preliminary evaluation of alterant geophysical tomography in welded tuff TI <French Translation> Estimation preliminaire de l'alteration dans un tuf soude par tomographie geophysique

764 Electromagnetic experiment to map in situ water in heated welded tuff: Preliminary results Rock mechanics: Proceedings of the 28th U.S. symposium

765 I Prototype Engineered Barrier System Field Tests (PEBSFT). Progress report through November 1,1988

766 I Permeability tests Prototype Engineered Barrier System Field Tests (PEBSFT). Progress report through November 1, 1988 TI <Augmentation> Permeability of fractured tuff around boreholes

767 I Prototype Engineered Barrier System Field Tests (PEBSFT) 
WHC-SD-TD-RPT-011

Revision 0

768 Colloids related to low level and intermediate level waste. Progress report for the period 1st July 1986 to 30th December. 1986

769 Essential Relationships Between in Situ Measurements and Laboratory Experiments for. Realistic Evaluation of Transport in the Neighbourhood of Geological Waste Storage Sites

770 i English> The closure of WIPP disposal rooms filled with various waste and backfill combinations

771 Evaluation of Water and Abrasive Blasting Techniques for Canister Decontamination-Radioactive Tests

772 Evaluation of stability of epoxy matrices for waste immobilisation using sup 137 CS as a tracer (Preprint no. SST-15) International symposium on radiochemistry and radiation chemistry (Piutonium - 50 years) (held at Bombay during February 4-7, 1991): Preprints volume

773 A sensitivity study of brine transport into a borehole containing a commercial high-level waste canister

774 Recent developments in stochastic modeling and upscaling of hydrologic properties in tuff

775 FT-IR analyses of the oxidative decomposition products of cyanoferrate wastes

776 I COBRA-SFS (Spent Fuel Storage): A Thermal-Hydraulic Analysis Computer Code: Volume 1, Mathematical Models and Solution Method

777 SATURATED PERMEABILITY MEASUREMENTS ON PUMICE AND WELDED-TUFFACEOUS MATERIALS.

778 Liquid permeability measurements on densely welded tuff over the temperature range 25 to $90 /$ sup $0 / C$ TI <Augmentation> NNWSI

779 Liquid Permeability Measurements on Densely Welded Tuff over the Temperature Range 25 to 90 deg C

780 Theoretical derivation of limiting solubilities of long-lived radionuclides in disposal IUPAC conference on chemical thermodynamics

781 | Potential for using a six-phase alternating current power supply system for in situ vitrification

782 | Pore pressure response to probe insertion and thermal gradient: ISIMU-II Thermal Response Studies. 1984 Subseabed Disposal Project annual report, October 1983 - September 1984

783 BWR Spent-Fuel Measurements with the ION-1/Fork Detector and a Calorimeter

784 I Solar radiation control coatings reduce maximum temperatures in exposed storage drums

785 Heat Transfer Analyses for Grout Disposal of Radioactive Double-Sheli Slurry and Customer Wastes

786 I Recent Re-Measurement of Neutron and Gamma-Ray Spectra 1080 Meters from the APRD (Army Pulse Radiation Division) Critical Facility

787 Acoustic P-wave velocity measurements of cataclastic effects in rock salt

788 Acoustic crosshole measurements of cataclastic thermomechanical behaviour of rocksalt Design and instrumentation of in situ experiments in underground laboratories for radioactive waste disposal. Proceedings TI La conception et 7 'instrumentation d'experiences in situ en laboratoires souterrains pour l'evacuation. des dechets radioactifs.. Comptes-rendus 
789 I Measured release kinetics of iodine and cesium from U0 sub 2 at high temperatures under reactor accident conditions Fission product transport processes in reactor accidents Field testing of waste forms using lysimeters Non-conventional measurement techniques for the determination of some long-lived radionuclides produced in nuclear fuel. Literature survey Research note

792 Evaluation of the potential for gas pressurization and free liquid accumulation in a HLW canister Annual meeting abstracts

793 Untersuchung det Thermisch Induzierten Wasserfreisetzung aus Polyhalitischem Steinsalz unter In situ Bedingungen Temperaturversuch 5 im Salzbergwerk Asse (Investigation of the Thermally Induced Water Liberation from Rock Salt with Polyhalite Seams under In situ Conditions - Temperature Test 5 in the Asse Salt Mine)

794 HAW-Simulationsversuch mit Kobalt-60-Quellen im Salzbergwerk Asse. FE-Bericht 1986. (HAW simulation experiments with cobalt-60 radiation sources in the Asse salt mine. $R$ and $D$ report 1986)

795 HAW Simulation Experiments with Cobalt-60 Radiation Sources in the Asse Salt Mine. R And D Report 1986

796 Nuclear Waste Repository Simulation Experiments. Asse Salt Mine TI <NOTE> Annual rept. for 1985

797 Nuclear waste repository simulation experiments. Asse salt mine. Annual report 1985

Brookhaven highlights, 1986-1987

799 Solid State Track Recorder neutron dosimetry in a simulated basalt geological waste repository

800 Treatise on the Measurement of Radioactive Argon in the Atmosphere TI <NOTE> Master's thes is

801 i Carbonate adsorption onto goethite as a function of $\mathrm{pH}$ and ionic strength TI <Augmentation> Yucca Mountain Project:al

802 Equivalent Energy Density concept: A preliminary reexamination of a technique for equating thermal loads

803 i Recovery of uranium using bifunctional resins (Preprint no. SST-17) International symposium on radiochemistry and radiation chemistry (P7utonium - 50 years) (held at Bombay during February 4-7, 1991): Preprints volume

804 Modeling of hydrologic perturbations during reverse circulation drilling: 1, System and model description

805 PORFL.0-3: A mathematical model for fluid flow, heat, and mass transport in variably saturated geologic media. Theory and numerical methods, Version 1.0

806 i Online analytical systems for the uranium solidification facility at SRS

807 Application of ion implantation and backscattering techniques to the analysis of nuclear waste glass corrosion

808 THERMODYNAMIC DATA FOR SELECTED ELECTROLYTES AT ELEVATED TEMPERATURES.

809 Synthesis and characterization of some phenolic resins for the selective removal of radiostrontium

810 Simplified Modeling Technique for the Thermal Analys is of Spent Nuclear Assemblies. 
WHC-SD-TD-RPT-011.

Revision 0

811 An overview of the Yucca Mountain Global/Regional Climate Modeling Program

812 | <English> Design of underground supports for high-level nuclear waste repositories TI <French Translation> Conception de soutenement souterrain pour depot de dechets hautement radioactifs

813 i Catalyst Study for the Decontamination of Glove-Boxe Atmospheres Containing Tritium at MPC Levels

814 Ra: A high efficiency, D-/sup $3 / \mathrm{He}$, tandem mirror fusion reactor: Appendix C

815 | <English> Effect of dry density on diffusion of some radionuclides in compacted sodium bentonite

816 Applied study on transfer of radioactive nuclides and heat diffusion around radioactive waste disposal cavern in deformable fractured rock mass Proceedings of the sixth international congress on rock mechanics

817 CTD data from the Madeira Abyssal Plain. Charles Darwin Cruise 1/85 818 CTD Data from the Madeira and Iberian Abyssal Plains. CHARLES DARWIN Cruises $3 / 85$ and $9 A / 85$

819 I CTD (Conductivity-Temperature-Depth) Data from the Madeira Abyssal Plain. Charles Darwin Cruise $1 / 85$

820 Benthic Boundary Layer - IOS (Institute of Oceanographic Sciences) Observationa] Programme: Discovery Gap Measurements, March 1984

821 CTD (Conductivity-Temperature-Depth) Data from the Madeira and Iberian Abyssal P.lains. Charles Darwin Cruises $3 / 85$ and $9 \mathrm{~A} / 85$

822 Benthic Boundary Layer - IOS (Institute of Oceanographic Sciences, Wormley, England) Observational Programme: Discovery Gap Measurements, March 1984

823 I CTD Data from the N.E. At7antic 31 Deg N - 46 Deg N, July 1982 Discovery Cruise 130

824 Benthic Boundary Layer. IOS (Institute of Oceanographic Sciences) Observational Programme Interim Report January 1983

825 CTD Data from Discovery Gap and the Madeira. Abyssal Plain

826 CTD data from the northeast Atlantic Ocean 22 deg N - 33 deg N, 19 deg W- 24 deg W, July 1983 during RRS DISCOVERY Cruises 138, 139

827 Study of Hydrological and Geochemical Data on Materials for the Final Cover of Subsurface Storage Sites

828 Thermal simulation of drift emplacement geotechnical and geophysical investigations in and around backfilled galleries Waste management ' 88 TI <Series/Collective> Volume I: Low-level waste

829 Permeability and Consolidation of Deep-Sea Sediments

830 Evidence of pore-water advection in the Madeira Abyssal Plain from pore-pressure and temperature measurements Geology and geochemistry of abyssal plains

831 Vapour Pressure of Americium(III) Chloride TI <NOTE> Diss. (Dr.rer.nat.)

832 Grain density measurements of ash flow tuffs: an experimenta] comparison of water immersion and gas intrusion pycnometer techniques

833 Distribution of alpha activity on rock core

834 Laboratory measurements of contaminant attenuation of uranium mi11 tailings leachates by sediments and clay liners 
WHC-SD-TD-RPT-011

Revision 0

835 Monitoring Sources of Nuclear Radiation in Space 1980-1984

Observations. Revision TI <NOTE> Memorandum rept. Apr 80-Jan 85

836 I A coupled spectrophotometric assay for routine assessment of carbamylation and $k$ c of rubisco

837 I Laboratory Testing of Cement Grouting of Fractures in Welded Tuff TI <NOTE> Technical rept. 1988-90

838 I Soil-to-plant transfer of carbon-14 for environmental assessment of radioactive waste repositories

839 I Tailings treatment techniques for uranium mill waste: a review of existing information TI <Augmentation> Neutralization processes, fixation processes, and specific constituent removal

840 I Preliminary experimental study on the deterioration of cementitious materials by acceleration method Transactions of the 11th international conference on structural mechanics in reactor technology

841 A rough crack constitutive model for concrete Transactions of the 11th international conference on structural mechanics in reactor technology

842 Pilot research projects for underground disposal of radioactive waste in Japan. Radioactive waste management. Volume 3 . Proceedings of an international conference held by the IAEA in Seattle, 16-20 May 1983

843 HIP devoluming treatment for radioactive waste Background information for the development of a low-level waste performance assessment methodology

846

Experimental Studies and Methods for Calculating Fission Product Release from Failed oxide Fuel Rods into an Organic Coolant Volatility of cesium and strontium from a synthetic basalt

847 Penetration and pullout forces for the ISHTE corers and probes Thermat Response Studies. 1984 Subseabed Disposal Project annual report, October 1983 - September 1984

848 Cruise report on In-Situ Vane system^ cruise: ATLAS-84, ISHTE component test, R/V Melville. Thermal Response Studies. 1984 Subseabed Disposal Project annual report, October 1983 - September 1984

849 Investigations of radionuclide migration through intact rock cores Second international conference on methods and applications of radioanalytical chemistry. Abstracts

850 Contributions to the Study of Environmental Radioactivity TI <NOTE> Thesis (Ph. D) Immobilization of incinerator ash in a concrete matrix. Energygrams: brief descriptions of energy technology Characterization of the Topopah Spring and Tiva Canyon Tuffs at Yucca Mountain TI <NOTE> Final report Separation of thorium from radioactive liquid waste by OXAL process MEASUREMENTS OF CESIUM AND STRONTIUM DIFFUSION IN BIOTITE GNEISS.

ROCK SAMPLES UNDER MECHANICAL STRESS.

857 Preliminary evaluation of PSCM and BIPP melter design and operating conditions using physical modeling

858 Geochemical modelling. Pt.1, Pt.2

859 Platform operation HOCUS cruise report

860. Predictions of radioactive tungsten release for hypothetical ITER (International Thermonuclear Experimental Reactor) accidents 
WHC-SD-TD-RPT-011

Revision 0

861 Three-dimensional contaminant plume dynamics in the vadose zone: Simulation of the 241-T-106 single-she11 tank leak at Hanford

862 - English> Interpretation of gravity data in a complex volcano-tectonic setting, southwestern Nevada TI <French Translation> Interpretation des donnees gravimetriques d'une zone volcano-tectonique complexe, Nevada Sud Ouest

863 The development of new microwave heating applications at Ontario Hydro's Research Division. Microwave processing of materials. 2

864 | <English> Developments, recommendations and applications of tests for evaluating the chemical stability of high-level radioactive solid waste forms

865 Volatilization studies of cesium and molybdenum during HLW solidification in sintered SYNROC-B crystalline waste forms

866 A study of the use of crosslinked high-density polyethylene for low-level radioactive waste containers

867 The impact of LWR decontaminations on solidification, waste disposal and associated occupational exposure

868 Demonstration of in situ vitrification for treatment of radioactively-contaminated soils at 0ak Ridge National Laboratory WATTec '92. Innovation in the 21st century: Excellence through continuous improvement

869. LEnglish> Soda ash treatment of a strontium-90contaminated groundwater seep

870 Performance of Diffusion-Barrier Scintillation Cells under a Variety of Controlled Environmental Conditions

871 EPRI (Electric Power Research Institute)/ANL (Argonne National Laboratory) Investigations of MCCI (Molten Core-Concrete Interactions) Phenomena and Aerosol Release

872 Devitrification and subsequent effects on the leach behavior of a simulated borosilicate nuclear waste glass

873 HEU confirmatory measurement instrument

874 Model for measuring productivity: A case study of a radioactive waste management facility TI <NOTE> Thesis (Ph.D)

875 WIPP hydrology program, Waste Isolation Pilot Plant, southeastern New Mexico: Hydrologic data report No. 6: Part A, Waste-handling shaft pulse testing^ Part $\mathrm{B}, \mathrm{H}-1, \mathrm{H}-12$, and $\mathrm{P}-15$ slug tests^ Part $\mathrm{C}, \mathrm{H}-2$ pumping test^ Part D, H-16, H-17, and $H-18$ drili-stem, slug, and pulse tests^ Part E, Water-level data

876 WIPP Hydrology Program Waste Isolation Pilot Plant, Southeastern New Mexico hydrologic data report No. 7: Parts A, WIPP-30, WIPP-12, and

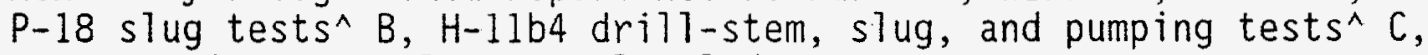
H-18 pumping test^ $\mathrm{D}$, water-level data

877. WIPP hydrology program, Waste Isolation Pilot Plant, southeastern New Mexico: Hydrologic Data Report No. 8

878 Waste Isolation Pilot Plant Salado hydrology program data report No. 2

879 Electrolytic recovery of copper and regeneration of nitric acid from a copper strip solution. Energy reduction techniques in metal electrochemical processes

880 Measured data from the Avery Is land, Louisiana, heating corejacking tests

881 Performance testing of the Doorstopper biaxial strain cel1 
WHC-SD-TD-RPT-011

Revision 0

882

Reference Thermal and Thermal/Mechanical Analyses of Drifts for Vertical and Horizontal Emplacement of Nuclear Waste in a Repository in Tuff

883

884

885

886

887

888

889

890

891

892

1986 WIPP horizon permeability measurements

Test plan: WIPP horizon gas flow/permeability measurements

Summary of 1988 WIPP (Waste Isolation Pilot Plant) Facility horizon gas flow measurements.

Summary of 1988 WIPP Facility horizon gas flow measurements

Summary of and observations about WIPP (Waste Isolation Pilot Plant) Facility horizon flow measurements through 1986

88 I In situ seal tests at the Waste Isolation Pilot Plant (WIPP) Waste management 86 . Volume 2: High-level waste

An alternate method for determining the $\mathrm{K} 1$ inkenberg correction

In situ measurements of rock salt permeability changes due to nearby excavation

Changes in rock salt permeability due to nearby excavation

Deformation and thermodynamic model for hydride precipitation kinetics in spent fuel cladding
893 Waste disposal by hydrofracture and application of the technology to the management of hazardous wastes Proceedings of the international conference on new frontiers for hazardous waste management

894

Release of Fission Products from WWER-440 Reactors under DBA

Conditions: Calculation Methods and Results for Zarnowiec NPP (Nuclear

Power Plant)

895 I A method of determining weight percent solids in SRAT/SME s7urries as a function of temperature

896 i A dry storage cask for utilization of WESF cesium-137 sources Waste management 187: Waste isolation in the US, technical programs, and public education TI <Series/Collective> Volume 3 - Low-level waste Closure, decontamination, and characterization of canisters of high-activity borosilicate glass. Proceedings of the international topical meeting on nuclear and hazardous waste management

898 ICARUS-LLNL

899 Uncertainty analysis on leaching rate measurements of nuclear waste glass. Radioactive waste products - suitability for final disposal. Proceedings

900 i <English> User's manual for SPECTROM-41; a finite-element heat transfer program

901 Performance Characteristics of a High-Level Solid-State Personnel Dosimetry System in Pulsed Radiation Environments

902. I The effect of porous support composition and operating parameters on the performance of supported liquid membranes

903 Empirical correlations from waste grout formulation data

904 Separation and extraction device for mixed radioactive waste water

905 Experimental method for determining distribution coefficients of TRU nuclides for evaluating their migration behaviors

906 i Results from the DCH-1 (Direct Containment Heating) experiment TI <Augmentation> Pressurized melt ejection and direct containment heating

907 PH sensors based on iridium oxide 
WHC-SD-TD-RPT-011

Revision 0

908

. Compatibility of candidate overpack materials with deep argillaceous HLW disposal environments. Materials reliability in the back end of the nuclear fuel cycle. Proceedings of a technical committee meeting held in Vienna, 2-5 September 1986

909 I In situ damage rate evaluation of overpack materials in deep argillaceous HLW disposal environments Improvements in materials reliability in the back end of the nuclear fuel cycle

910 i Methodology for evaluating the aqueous leach resistance of a glass used in a characterization study Radioactive waste products suitability for final disposal. Proceedings

911 Measurements of matric and water potentials in unsaturated tuff at Yucca Mountain, Nevada

912 Coupled heat and mass transfer in unsaturated soil. A potential-based solution.

913 Review of techniques for partitioning highly active waste

914 Comparison of under-Pressure and over-Pressure Pulse Tests Conducted in Low-Permeability Basalt Horizons at the Hanford Site, Washington State

915 Radioactive waste repositories in hard rock aquifers--hydrodynamic aspects

916 | X-ray and visible light transmission as two-dimensional, full-field moisture-sensing techniques: A preliminary comparison TI <Augmentation> Yucca Mountain Project

917 L. Byproducts utilization management program. ORNL nuclear waste programs annual progress report for period ending September 30, 1982

918 WESF Cesium Capsule Behavior at High Temperature or During Thermal Cycling

919 WESF cesium capsule behavior at high temperature or during thermal cycling

920 Krypton-85 storage in sputtered-deposited amorphous metals Methods of krypton 85 management TI <Series/Collective> Radioactive waste management. Volume 10

921 Uranium oxide--iron oxide mixed aerosol experiments in steam--air atmospheres: NSPP Tests 611, 612, 613, and 631, Data record report

922 Role of Soil Characteristics on Analysis of Water Flow in Shallow Land

923 Helium-4 model ages for pore fluids from fractured 1 ithologies. Discussion and application. Isotopes of noble gases as tracers in environmental studies TI <Original Series/Collective> Panel proceedings series

924 I Test plan: Heated axisymmetric pillar TI <Augmentation> Waste Isolation Pilot Plant

925 Development, implementation, and early results: Test Series D, Phase 1 of the smali-scale seal performance tests

926 Sorption of americium in tuff and pure minerals using synthetic and natural groundwaters

927 i Determination of. DWPF process stream yield stress and consistency using capillary viscometer technique

928 Advances in the Department of Energy's Prototypical Consolidation Demonstration Project

929 I Multiparameter testing of permeability by the transient vacuum technique. Coupled processes associated with nuclear waste repositories 
WHC-SD-TD-RPT-011

Revision 0

930 Analysis of permeability reduction during flow of heated, aqueous fluid through westerly granite. Coupled processes associated with nuclear waste repositories

931 S1ip-flow experiments in welded tuff TI The Knudsen diffusion problem. Coupled processes associated with nuclear waste repositories

932 i Coupled hydrothermal flows of liquid and vapor in welded tuff. TI Numerical modeling of proposed experiment Coupled processes associated with nuclear waste repositories

933 Field investigation of disturbed zones around excavations by strain distribution measurements. Coupled processes associated with nuclear waste repositories

934 i <English> A study of coupled thermomechanical, thermohydrological, and hydromechanical processes associated with a nuclear waste repository in a fractured rock medium

935 Permeability and dispersivity of variable-aperture fracture systems.

936 Crevice corrosion - $\mathrm{NaCl}$ concentration map for grade-2 titanium at elevated temperature

937 <English> Effects of biotite distribution on cesium diffusion in granite

938 Deep installations of monitoring instrumentation in unsaturated welded tuff. Hydrogeology of rocks of low permeability: Memoirs, Volume 17:

Part 2, Proceedings

939 Waste gas processing device

940 A melt refining method for uranium-contaminated aluminum

941 Characteristics of a foil-type electret dosimeter for a surface alpha contamination monitor

942 Melting treatment device for radioactive waste

943. Japanese approaches to the assessment of radionuclide migration in the geosphere

944. I Interactions with other fields

945 Coupled analysis of flow and heat around a high-level nuclear waste repository. Numerical methods in geomechanics

946 Axial transport effects on natural convection inside of an open-ended annulus

947 NORDA contribution to the in-situ heat transfer experiment (ISHTE): FY84 annual report. Thermal Response Studies. 1984 Subseabed Disposal Project annual report, October 1983 - September 1984

948 Alternative preparative methods for sphene glass-ceramics

949 <English> Thermal migration of brine inclusions in sodium chloride single crystals

950 i Behavior of a Single U02 Sphere, Irradiated at Approximately $1900 \mathrm{~K}$ in the High Flux Reactor (HFR) at Petten (The Netherlands)

951 Device for the continuous production of glass bodies especially containing radioactive waste

952 Avery Island heater tests: measured data for 1000 days of heating

953 Activity release from waste packages containing ILLW-cemented waste forms under mechanical and thermal stresses. Testing, evaluation and shallow 1 and burial of $10 \mathrm{w}$ and medium radioactive waste form

954 - Early phyllosilicates formed by alteration of R7T7 glass in water at $250 \mathrm{deg} C$ 
WHC-SD-TD-RPT-011

Revision 0

Geotechnical behaviour of salt under repository conditions Radioactive waste management. Volume 3 . Proceedings of an international conference held by the IAEA in Seattle, 16-20 May 1983

956

Special problems in making geotechnical measurements in salt

Tests

958 Measurements of Thermodynamic Constants of Transuranic Compounds to Predict Their Geochemistry: Carbonate Complexation of $\mathrm{Np}(\mathrm{V})$ And Am(III), Hydrolysis of Pu(VI) And AM(III)

959 I Method of determining particle dispersion in nuclear power station coolant

960 Occupational health, waste management, and environmental research program of the Health Division 1981. Progress report

961 GMS measurement of B1 liner deformation

962 Salt pressure derived from GMS-BI measurements

963 In-situ experiments on the time dependent thermo-mechanical behaviour of rock salt Design and instrumentation of in situ experiments in underground laboratories for radioactive waste disposal. Proceedings

964 Specific investigations related to salt rock behaviour Radioactive waste management and disposal

965 | Untersuchungen zur Temperaturfernmessung durch Analyse der

Rayleigh-Streuung mit Atomdampffiltern. (Investigations of remote temperature measurement by analysis of Rayleigh scattering with atomic vapor filters) TI <NOTE> Diss

966 C Comparison and Evaluation of Field and Numerical Results from the Site A Heater Test at Avery Island

967 EXPERIMENTAL CONCRETES FOR SEALING RADIOACTIVE-WASTE REPOSITORIES IN EVAPORITE STRATA.

968 Measured data from the Avery Is 1 and. Site $C$ heater test

969. Three-well technique for determining formation anisotropy at the Waste Isolation Pilot Plant (WIPP), southeast New Mexico TI <Augmentation> Culebra dolomite unit of the Rustler Formation

970 Thermal monitoring of the cement checking Exotherm and its application to the quality of cemented wastes

971

972 Heatup of the TMI-2 lower head during core relocation Aspects of fluid flow through small flaws in membrane liners

973 Heatup of the TMI-2 (Three Mile Island-2) Lower Head during Core Relocation

974 TRU waste-sampling program

975. Analysis of bellows expansion joints in containment buildings

976

977 Evaporation measurement in the validation drift - part 2 The structural response of WIPP disposal room with internal gas
generation

978 The closure of WIPP disposal rooms filled with various waste and backfill combinations

979. Iodine chemical forms in LWR severe accidents

980

Use of Fiber Optics for Remote Temperature Measurement in Fission Product Release Tests

981 Liquid level measurement in high-level nuclear waste slurries

982

983

Mathematical Modeling of Heat Transfer in Pu-238 Ion Exchange Columns Temperature data 
984 Diffbaion and permeability used sorption measurements in intact rock samples

985 Summary report on the release of fission products from irradiated SRP fuel at elevated temperatures

986 Measurement of the ductile to brittle transition temperature for waste tank cooling coils

987 Evaluation and development of hydrogeological and geochemical investigation methods for aquifers of low permeability

988 Development of a grout-based stabilization method for spent high-temperature gas-cooled reactor fuel Waste Management 185: Waste Isolation in the US - Technical Programs and Public Education. Volume 2. Waste policies and programs, low-level waste

989 | Time-dependent microcracking in plutonic rock due to heat from a nuclear-fuel waste vault Research and engineering applications in rock masses. Volume 1

990 i Monitoring of heat and moisture migration from radioactive waste disposed in an augered shaft Waste management 187: Waste isolation in the US, technical programs, and public education TI <Series/Collective> Volume 1 - General interest

991

992

993 Analysis of pumping test data: Sawyer No. 1; Mansf Hydrogeologic impacts of mine design in unsaturated rock

994 I PRESSURE AND DENSITY MEASUREMENTS OF SELECTED FLUID-BEARING ZONES AT THE WASTE ISOLATION PILOT PLANT (WIPP).

995 I Prediction of Far-Field Subsurface Radionuclide Dispersion Coefficients from Hydraulic Conductivity Measurements: A Multidimensional Stochastic Theory with Application to Fractured Rocks TI <NOTE> Topical technical rept. Sep 81-Dec 83

996 i Numerical modeling of regional ground-water flow in the deep-basin brine aquifer of the Palo Duro Basin, Texas Panhandle

997 Time-integrated radon soil-gas surveys in geothermal exploration in the Southern Rio Grande Rift, New Mexico. Volume 1; Final report TI <NOTE> Progress rept

998 Hydrogeological testing to characterize a fractured granite 7. international congress on rock mechanics

1000 Use of a commercial heat transfer code to predict horizontally oriented spent fuel rod temperatures

1001 i Numerically predicting horizontally oriented spent fuel rod surface temperatures

1002 I Measurement of the oxidation of spent fuel between 140/degree/ and $225 /$ degree/C by thermogravimetric analysis

1003 Measurement of the Oxidation of Spent Fuel between 140 and 225C by Thermogravimetric Analysis

1004 <English> Natural convection and dispersion in a tilted fracture

1005 Survivability Tests on a Nuclear Waste Cask in Simulated Railroad Accident Fires TI 〈NOTE> Final rept.

1006 Incineration method for plutonium recovery from alpha-contaminated organic compounds

1007 Numerical analysis of laminar free convection in square cavity containing heat generating $\mathrm{kr}-85$ gas

1008 Method for treating radioactive organic wastes 
1009 Immobilization of high-level radioactive waste by hydrothermal hot-pressing method Chemical aspects of down stream for thorium fuel cycle

1010 Evaluating reconstruction algorithms for electrical impedance tomography Engineering research and development: Thrust area report, FY 87

1011 Determination of trace amounts of thallium in commercial radioactive / sup 204/Tl samples by the Redox sub-superequivalence method of isotope dilution analysis

1012 The effect of liner hydraulic conductivity on disposal cel1 performance

1013 | BWR in-plant emergency responses during degraded core accidents

1014 General view on ceramics in nuclear industry

1015 Pore volume and pore size distribution of cement samples measured by a modified mercury intrusion porosimeter

1016 Dependence of the Actinide Nuclide Buildup on the Coolant Density Height Distribution in the RBMK Core

1017 I Gas generation and migration studies involving recently generated / sup 238/Pu-contaminated waste for the TRU Waste Sampling Program

1018 Geotechnical instrumentation requirements for atdepth testing and repository monitoring in tuff

1019 Evaluation of the accuracy of continuum-based computational models in relation to field measurements in welded tuff TI <Augmentation> Jointed welded tuff

1020 i Nevada Nuclear Waste Storage Investigations Project: G-Tunnel small-diameter heater experiments: Final report

1021 S Summary of Geochemical Measurements Taken in and around the G-Tunnel Underground Facility, NTS (Nevada Test Site)

1022 G-tunnel pressurized slot-testing evaluations. Yucca Mountain Site Characterization Project

1023 G-tunnel pressurized slot-testing evaluations

1024 AMBIENT TEMPERATURE TESTING OF THE G-TUNNEL HEATED BLOCK.

1025 Fixation of strontium on polyantimonic acid

1026 FEHMN 1.0: Finite element heat and mass transfer code 
WHC-SD-TD-RPT-011

Revision 0

\section{APPENDIX E. \\ SEARCH RESULTS FOR PHYSICAL PARAMETERS \\ ON CD-ROM MASTER VENDOR CATALOG}

Reproduced from Information Handling Services.

Vendor Master Directory. Mar-Apr 1994 Issue.

Tue Nov 02 07:03:52 1993

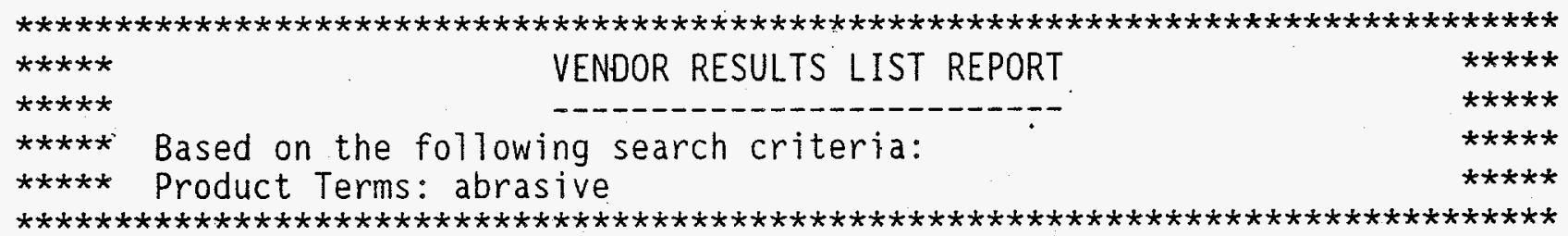

*A I M CORP

*ABRASIVE INDUSTRIES INC/BAY STATE ABRASIVE PRODUCTS

*ACCURATE DIAMOND TOOL CORP

*AIR PLACEMENT EQUIPMENT CO INC

*ALLISON ABRASIVES INC

*ALLOY TECHNOLOGY INTERNATIONAL INC

*ALPEX WHEEL CO

*AMERICAN HOFMANN CORP

*AMPCO-PITTSBURGH CORP/BUFFALO FORGE CO

*ASTRO MET INC

*ATOMERGIC CHEMETALS CORP

*AVERY DENNISON CORP/AVERY SPECIALTY TAPE DIV

*BALDOR ELECTRIC CO/BALDOR MOTORS \& DRIVES

*BATES ABRASIVE PRODUCTS INC

*BETHAM CORP

*BINKS MANUFACTURING CO

*BLACK \& DECKER CORP/BLACK \& DECKER (U S) INC

*BUEHLER LTD

*CARBORUNDUM ABRASIVES NORTH AMERICA

*CARMET CO

*CATAPHOTE INC

*CENTRO-METALCUT INC

*CHEMETRON RAILWAY PRODUCTS INC

*CHICAGO PNEUMATIC TOOL CO/TOOL DIV

*CINCINNATI MILACRON INC/CINCINNATI MILACRON RESIN ABRASIVES

*CINCINNATI MILACRON INC/PRODUCTS DIV

*CLIPPER DIAMOND TOOL CO INC

*COBURN OPTICAL INDUSTRIES INC

*CONTINENTAL SEAL

*COOPER INDUSTRIES INC/COOPER TOOLS DIV (QUALITY TOOLS/EQUIPMENT)

*CRYSTAL MARK INC

*CURTISS-WRIGHT CORP/METAL IMPROVEMENT CO INC

*CUSHION CUT INC 
*CUSTOM METAL FABRICATORS INC/VACUBLAST

*CUSTOMEDIX CORP/JENERIC-PENTRON INC *DARLING INDUSTRIES INC/DURODYNE INC

*DAYTON ABRASIVE PRODUCTS CO

*DELTA/DUCON INTERNATIONAL INC

*DIAMANT BOART

*DISCO HI-TEC AMERICA INC

*DISSTON CO

*DIVERSEY CORP/DU BOIS U S A GROUP

*DIVINE BROTHERS CO

*DOALL CO

*DOALL CO/SOUTHWEST-DOALL INDUSTRIAL SUPPLY CO

*DOVER CORP/DOVER RESOURCES INC/BLACKMER PUMP

*DU PONT CO/CHEMICALS \& PIGMENTS

*DU PONT CO/FABRICATED PRODUCTS

*E $G \&$ \& INC/E G \& G FLOW TECHNOLOGY

*EMERSON ELECTRIC CO/SKIL CORP

*EQUIPMENT DEVELOPMENT CO INC

*ERVIN INDUSTRIES INC

*ESSEX GROUP INC/INDUSTRIAL PRODUCTS DIV

*EUTEK SYSTEMS

* FAHRINGER ( $T$ L) . CO

*FALCON TOOL CO INC

*FAMTEC INTERNATIONAL INC/SPEEDFAM CORP

*FEL-PRO CHEMICAL PRODUCTS L P

* FLEXBAR MACHINE CORP

*G M N/WHITNON SPINDLE DIV

* GENERAC CORP

*GENERAL ELECTRIC CO

*GENERAL ELECTRIC CO/G E SUPERABRASIVES

* GENERAL RESOURCE CORP

*GENERAL TOOLS MANUFACTURING CO INC

* GIBRALTAR NATIONAL CORP

*GO/DAN INDUSTRIES MANUFACTURING CO

*GOODALL RUBBER CO

*GOULDS PUMPS INC

*GRACO INC

*GRAINGER (W W) INC

*GROVER PRODUCTS CO

*GUYSON CORP

*HILTI INC

*HIRSCHMANN CORP

*HYDRO-PAC INC

*IDEAL INDUSTRIES INC

*IDEX CORP/VIKING PUMP. INC

*INGERSOLL-RAND CO/WATERJET .CUTTING SYSTEMS DIV

*J S J CORP/DAKE CORP

* JASON INC/JACKSON LEA

* JESSOP STEEL CO

* JOHN CRANE INC

*K-LINE INDUSTRIES INC

*KALAMAZOO CO/HAMMOND MACHINERY INC 
WHC-SD-TD-RPT-011

Revision 0

*KALAMAZOO CO/ROTO-FINISH CO INC

*KANSAS INSTRUMENTS INC

*KUSTM CHEMICAL CORP

* LECO CORP

* LINDSAY (P K) CO INC

* ITTON INDUSTRIES INC/LITTON INDUSTRIAL AUTOMATION/DIAMOND \& C B N PRODUCTS

* LITTON INDUSTRIES INC/LITTON INDUSTRIAL AUTOMATION/DISC GRINDERS \& ABRASIVES

* LOBEE PUMP \& MACHINERY CO

* LOCTITE CORP/AUTOMOTIVE \& CONSUMER GROUP

* LORD CORP/CHEMICAL PRODUCTS DIV

*MAC TOOLS INC

*MARTTINDALE ELECTRIC CO

*MATCO TOOLS

*MC MASTER-CARR SUPPLY CO

*MERCK \& CO INC/KELCO DIV

*METABO CORP

*METAL REMOVAL INDUSTRIAL TOOLING

*MILLER THERMAL INC

*MILWAUKEE ELECTRIC TOOL CORP

*MOORE SPECIAL TOOL CO INC

*MORSE (M K) CO

* MOYCO INDUSTRIES INC

*MULTI MACHINE

*NATIONAL GRINDING WHEEL CO INC

*NORTEL MACHINERY INC

*NORTHEAST INDUSTRIES INC

*NORTON CO/ABRASIVES MARKETING GROUP

*NORTON CO/SAINT-GOBAIN-NORTON INDUSTRIAL CERAMICS CORP

*NU-MATIC GRINDERS INC

$* P$ \& F INDUSTRIES INC/FLORIDA PNEUMATIC MANUFACTURING CORP

*PAASCHE AIRBRUSH CO

*PACIFIC GRINDING WHEEL CO INC

*PANGBORN CORP

*PARKER HANNIFIN CORP/FLUIDCONNECTOR PRODUCTS/STRATOFLEX AEROSPACE-MILITARY CONNECTORS DIV

*PAULI \& GRIFFIN CO

*PAXTON (FRANK) LUMBER CO

*PENTAIR CO/DELTA INTERNATIONAL MACHINERY CORP

*PFINGST \& CO INC

*PISTORIUS MACHINE CO INC

*POLLARD (JOSEPH G) CO INC

*POLLEY INC/KELCO SALES \& ENGINEERING DIV

*POSSIS CORP/JET EDGE INC

*PRECISION PROFILES INC

*PRES-ON PRODUCTS INC/PRES-ON ABRASIVES DIV

*PRES-ON PRODUCTS INC/TAPE \& GASKETING DIV

*PROGRESSIVE BLASTING SYSTEMS INC/PROGRESSIVE TECHNOLOGIES

*RADIAC ABRASIVES

*RADIATOR SPECIALTY CO (CAR CARE)

*RED DEVIL INC

*REGAL DIAMOND PRODUCTS CORP

*RICHARDS (J A) CO 
WHC-SD-TD-RPT-011

Revision 0

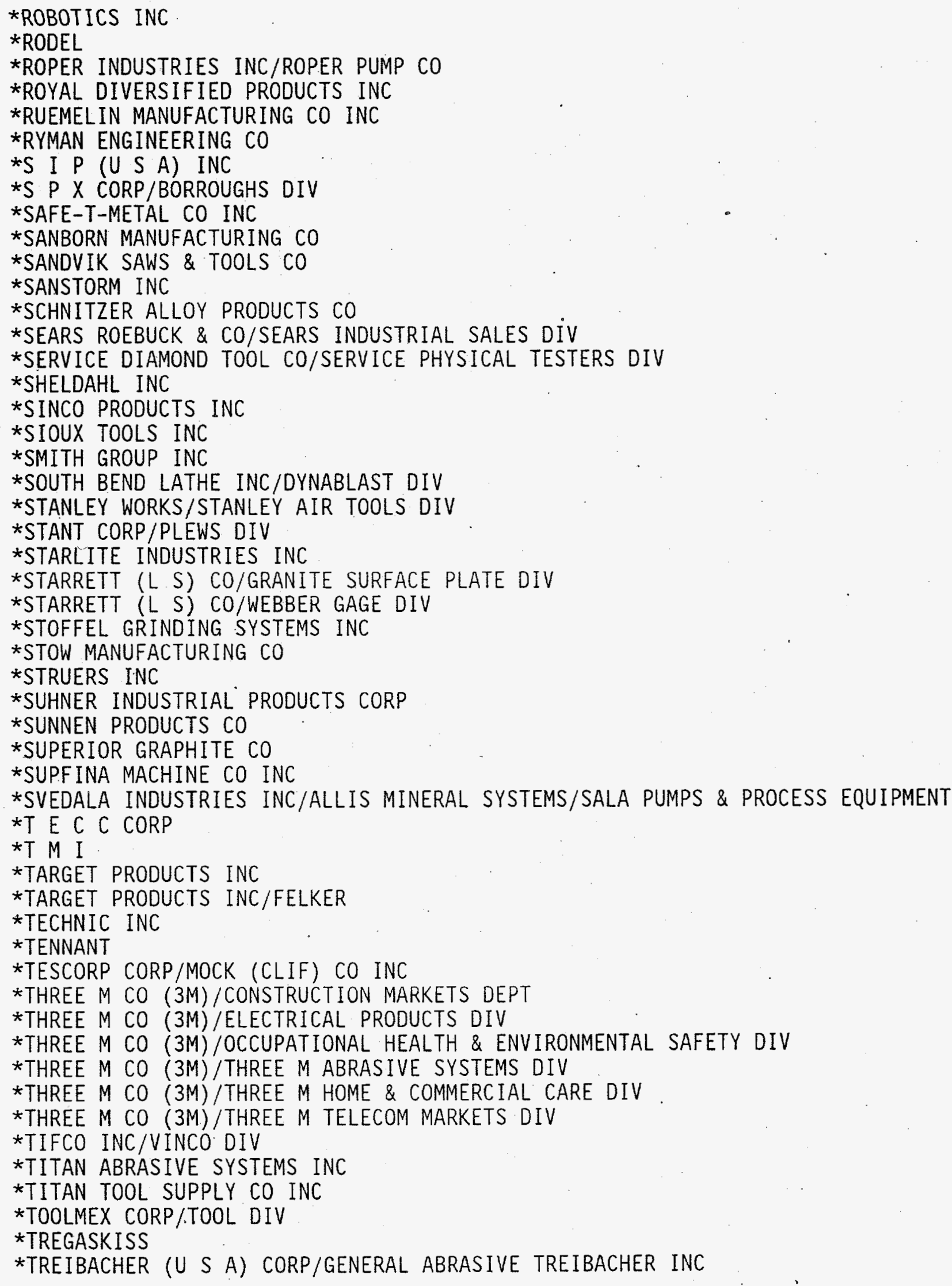


WHC-SD-TD-RPT-011

Revision 0

*TRI-CON INC

*TRITAN CORP

*TUNCO MANUFACTURING INC

*TUTHILL CORP/TUTHILL PUMP DIV

*U S ELECTRICAL TOOL INC

*U S TECHNOLOGY CORP

*UNION CARBIDE CORP/UNION CARBIDE COATINGS SERVICE CORP/ADVANCED CERAMICS

*UNITED ABRASIVES INC

*UNIVERSAL EQUIPMENT MANUFACTURING CO INC

*UNIVERSAL FINISHING MACHINES INC

*UNIVERSAL PHOTONICS INC

*UNIVERSAL SUPERABRASIVES/ELGIN DIV

*UNIVERSAL SUPERABRASIVES/METAL \& INDUSTRIAL GRINDING DIV

*VERMONT AMERICAN CORP/VERMONT AMERICAN TOOL CO

*VULCAN ENGINEERING CO/FOX GRINDERS DIV

*WASHINGTON MILLS CERAMICS CORP

*WASHINGTON MILLS ELECTRO MINERALS CORP

*WEN PRODUCTS INC

*WHEELABRATOR TECHNOLOGIES INC/WHEELABRATOR CORP

*WILCO SUPPLY CO

*WILSON (THOMAS C) INC.

*WILTON CORP/MACHINERY \& TOOL

*WOOD (MORRIS) TOOL CO INC

*YEOMANS CHICAGO CORP 
WHC-SD-TD-RPT-011

Revision 0

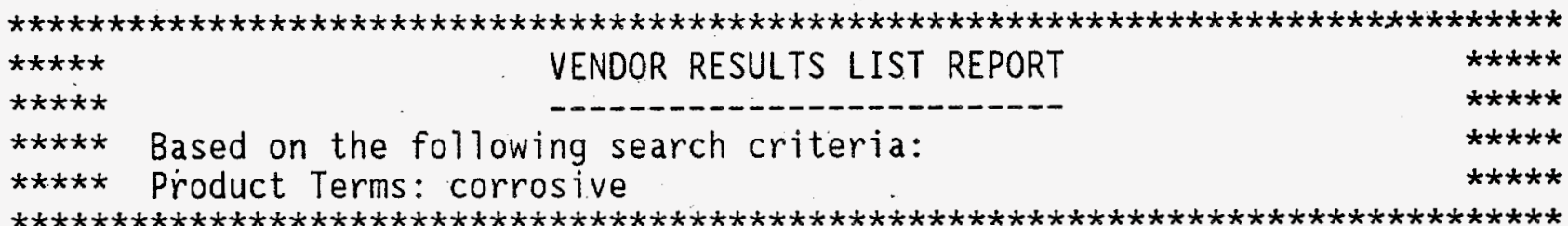

*A S E A BROWN BOVERI -INC/A B B KENT-TAYLOR

*AALBORG INSTRUMENTS \& CONTROLS INC

*AIR PRODUCTS \& CHEMICALS INC/INDUSTRIAL GAS DIV/SCHUMACHER

*AMPCO-PITTSBURGH CORP/BUFFALO FORGE CO

*ANAMET INC

*ANCHOR PACKING CO

*ANCO TECH INC

*ARMSTRONG INTERNATIONAL INC

*ASAHI / AMERICA INC

*BAILEY CONTROLS CO

*BAKER HUGHES INC/BAKER HUGHES PRODUCTION TOOLS/BAKER C A C/PNEU-HYDRO

PRODUCTS INC

*BARNEBEY \& SUTCLIFFE CORP

*BINKS MANUFACTURING CO

*CACTUS PAINT MANUFACTURING CO INC

*CARPENTER TECHNOLOGY CORP/CARPENTER STEEL DIV

*CHEM-TEC EQUIPMENT CO INC

*CHESTERTON (A W) CO

*COLTEC INDUSTRIES INC/DELAVAN ELECTRONICS, PROCESS INSTRUMENTATION OPERATION

*COLTEC INDUSTRIES INC/GARLOCK MECHANICAL PACKING DIV

*COMMERCIAL INTERTECH CORP/CUNO INC, PROCESS FILTRATION PRODUCTS

*CRUCIBLE MATERIALS CORP/TRENT TUBE DIV

*DRESSER INDUSTRIES INC/INDUSTRIAL INSTRUMENT OPERATIONS

*DWYER INSTRUMENTS INC

*EMERSON ELECTRIC CO/BROOKS INSTRUMENT DIV

*EMERSON ELECTRIC CO/WIEGAND (EDWIN L) DIV

*F. S I INTERNATIONAL

*FAIRCHILD INDUSTRIAL PRODUCTS CO

*FALEX CORP

*FAST HEAT ELEMENT MANUFACTURING CO INC

*FOX VALVE DEVELOPMENT CO INC

*G F S CHEMICALS INC

*GENERAL VALVE CORP

$*$ GORMAN-RUPP CO

*GRINNELL SUPPLY SALES CO

*HANSON INDUSTRIES/HALKEY-ROBERTS CORP

* I T T CORP/I T T FLUID TECHNOLOGY CORP/I T T CONOFLOW

*INLAND STEEL INDUSTRIES INC/TULL (J M) METALS CO INC

*JESSOP STEEL CO

*K I P INC

*KETEMA CORP/SCHUTTE \& KOERTING DIV

*KROHNE-AMERICA INC

*MALLINCKRODT INC/MALLINCKRODT SPECIALTY CHEMICALS CO/PERFORMANCE \& LABORATORY CHEMICALS 
WHC-SD-TD-RPT-011

Revision 0

*MATERIAL CONTROL INC

*MATHESON GAS PRODUCTS INC

*MERCK \& CO INC/CALGON CORP

*NU-TECH PRECISION METALS (U S A) INC

*NUMATICS INC/NUMATICS ACTUATOR

*OMEGA ENG INEERING INC

*PALL CORP/MECTRON INDUSTRIES INC

*PARKER HANNIFIN CORP/FLUIDCONNECTOR PRODUCTŚPARFLEX DIV

*PARKER HANNIFIN CORP/FLUIDPOWER PRODUCTS/COMMERCIAL FILTERS DIV

*PARKER HANNIFIN CORP/REFRIGERATION COMPONENTS GROUP/FLUIDEX DIV

*PARKER HANNIFIN CORP/REFRIGERATION COMPONENTS GROUP/REFRIGERATION \& AIR CONDITIONING DIV

*PLAS-CHEM COATINGS INC

*PURAFIL INC

* RACINE FEDERATED INC/HEDLAND PRODUCTS DIV

*ROBBINS \& MYERS INC/FLUIDS HANDLING GROUP

*RUST-OLEUM CORP

* SCANIVALVE CORP

* SCHLEYER (E C) PUMP CO INC

*SEALING EQUIPMENT PRODUCTS CO

*SIEBE NORTH INC/ROBERTSHAW TENNESSEE

*SPECTRA GASES INC

*TELEDYNE INC/TELEDYNE HASTINGS-RAYDIST

*TELEDYNE INC/TELEDYNE REPUBLIC/SPRAGUE

*TESCORP CORP/MOCK (CLIF) CO INC

*U S PARA PLATE CORP/APCO CONTROLS DIV.

*UEHLING INSTRUMENT CO

*UNIROYAL TECHNOLOGY CORP/ENSOLITE INC

*UNIVERSAL FLOW MONITORS INC

*VENTFABRICS INC

*WAHL INSTRUMENTS INC

*WHITMAN CONTROLS CORP

*YEOMANS CHICAGO CORP 
WHC-SD-TD-RPT-011

Revision 0

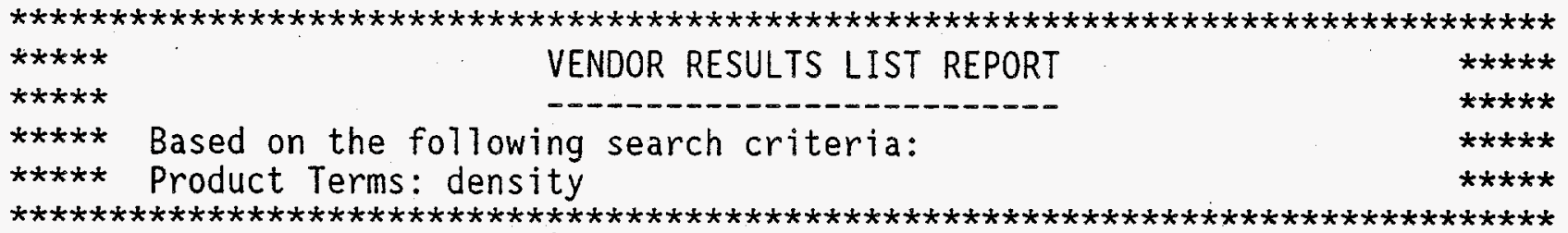

*A A R CORP/A A R BROOKS \& PERKINS/ADVANCED STRUCTURES DIV

*A D C TELECOMMUNICATIONS INC

*ADJUSTABLE STEEL PRODUCTS CO INC

*ALLIED RESINOUS PRODUCTS INC

*AMERACE ELECTRONIC COMPONENTS

*AMERICAN CYANAMID CO/D AIRCRAFT PRODUCTS INC

*AMP-AKZO CORP/RIVERHEAD CIRCUITS

*ANACOMP INC/XIDEX CORP

*ANALTECH INC

*ANDOVER CORP

*ARCCO INSTRUMENT CO INC

*ASAHI/AMERICA INC

*ASHLAND OIL INC/ASHLAND CHEMICAL INC/THERMOPLASTIC SERVICES DIV

*ASSURANCE TECHNOLOGIES INC/ROENTGEN-INDUSTRIAL CORP

*AUGAT INC/AUGAT COMMUNICATIONS GROUP INC

*AUGAT INC/INTERCONNECTION PRODUCTS GROUP

*B A S F CORP/INFORMATION SYSTEMS

*B I C C-VERO ELECTRONICS INC

$* B$ Y K-GARDNER INC

*BELL \& HOWELL CO/DOCUMENT MANAGEMENT PRODUCTS CO

*BERTHOLD SYSTEMS INC

*BETA INDUSTRIES INC/BETA SCREEN CORP

*BIO-RAD LABORATORIES

*BRABENDER ( $C W$ ) INSTRUMENTS INC

*BRINKMANN INSTRUMENTS INC

*BROOKLYN THERMOMETER CO INC

${ }^{*} C$ \& M CORP

*C V I LASER CORP

*CAMBRIDGE PRODUCTS CORP

*CARGILLE (R P) LABORATORIES INC

*CERAMIC MAGNETICS INC

*CHAMPION TECHNOLOGIES. INC

*CHEVRON CORP/CHEVRON CHEMICAL CO/OLEFINS \& DERIVATIVES DIV

*CIBA-CORNING DIAGNOSTICS CORP/GILFORD SYSTEMS

*CIRCUIT ASSEMBLY CORP

*COLE-PARMER INSTRUMENT CO

*COMMERCIAL PLASTICS \& SUPPLY CORP

*COMPUTER INSTRUMENTS CORP

*CONSOL IDATED ELECTRONIC WIRE \& CABLE INC

*CONTACT ELECTRONICS INC

*CORION CORP

*D S M ENGINEERING PLASTICS

*DIAGNOSTIC-RETRIEVAL SYSTEMS INC/PHOTRONICS CORP 
WHC-SD-TD-RPT-011

Revision 0

*DOW CHEMICAL CO

*DU PONT CANADA INC/PLASTICS DIV

*DU PONT CO/ELECTRONIC PRODUCTS (MODULAR INTERCONNECTION SYSTEMS)

*E G \& G INC/E G \& G SPECIAL PROJECTS

*E $G \& G$ PROCESS MEASUREMENT CHANDLER

*E L E INTERNATIONAL INC/SOILTEST PRODUCTS DIV

*EASTMAN KODAK CO/EASTMAN CHEMICAL CO

*EDAC INC

*ELECTRONIC CONTROLS DESIGN INC

*ELECTRONIC SYSTEMS ENGINEERING CO

*EMERSON ELECTRIC CO/ROSEMOUNT INC/KAY-RAY, SENSALL INC

*ENTRELEC INC

*ENVIROTECH CORP/T N TECHNOLOGIES INC

*EUCLID CHEMICAL CO

*EVER READY THERMOMETER CO INC

* FIBER MATERIALS INC

* FISH-SCHURMAN CORP

*FISHER SCIENTIFIC

*FURON CO/DEKORON

* GAMMON TECHNICAL PRODUCTS INC

*GENERAL MICROWAVE CORP

*GOW-MAC INSTRUMENT CO

*GRAPHICS MICROSYSTEMS INC

* GREAT LAKES PLASTIC CO INC

*H-B INSTRUMENT CO

*HALLIBURTON CO/HALLIBURTON SERVICES DIV/SPECIAL PRODUCTS DIV

*HALLIBURTON LOGGING SERVICES INC

*HEITZ (KARL) INC

*HEWLETT-PACKARD CO/MEDICAL PRODUCTS GROUP

*HOGEN INDUSTRIES INC

*HOLLYWOOD FILM CO

*HOMACO INC

*HONEYWELL INC/COMMERCIAL BUILDINGS GROUP

*HOUSTON FEARLESS SEVENTY SIX (76) INC

*HUMBOLDT MANUFACTURING CO

* I L C TECHNOLOGY INC

*I M B C O CORP

* IDEAL INDUSTRIES INC

*ILLINOIS TOOL WORKS INC/I T W PLASTIGLIDE MANUFACTURING DIV

*INLAND STEEL INDUSTRIES INC/RYERSON (JOSEPH T) \& SON INC

* INTEGRATED DEVICE TECHNOLOGY INC

*J A E ELECTRONICS INC

* JANOS TECHNOLOGY INC

*KAHL SCIENTIFIC INSTRUMENT CORP

*KEITHLEY INSTRUMENTS INC/INSTRUMENTS DIV.

*KESSLER (WALTER H) CO INC

*KETEMA CORP/SCHUTTE \& KOERTING DIV

*KOEHLER INSTRUMENT CO INC

*KOLLMORGEN CORP/MACBETH

*KONICA MEDICAL CORP

*KULITE TUNGSTEN CORP

*KYOCERA INTERNATIONAL INC/ELCO CORP 
WHC-SD-TD-RPT-011

Revision 0

*L-K INDUSTRIES INC

*L $P$ L TECHNOLOGIES INC/AMPHENOL CORP, INDUSTRIAL TECHNOLOGY DIV

* LABCONCO CORP

* LITTON INDUSTRIES INC/WINCHESTER ELECTRONICS DIV

* LONGYEAR CO/BRAINARD-KILMAN DRILL CO

* LUXTRON CORP

*M.FOUR (M4) DATA INC

*MANDOVAL VERMICULITE PRODUCTS INC

*MATERIAL CONTROL INC

*MELLES GRIOT

*METAVAC INC

*METRUM INFORMATION STORAGE

*METTLER-TOLEDO INC

*MICRO MOTION INC

*MICROPAC INDUSTRIES INC

*MOLEX INC

*MONMOUTH PLASTICS INC

*MOUNTAIN NETWORK SOLUTIONS INC

*NASHUA OFFICE PRODUCTS

*NATIONAL PARTICLEBOARD ASSOCIATION

*NETWORK EQUIPMENT TECHNOLOGIES INC

*NEWAGE INDUSTRIES INC/PLASTICS DIV

$\star N E W P O R T$ SCIENTIFIC INC

*NORLAND CORP

*NORWESCO INC/NORWESCO INTERCONNECTS DEVICES

*OHMART CORP

*OMEGA ENGINEERING INC

*OMEGA OPTICAL INC

*ORIEL CORP

*ORTRONICS INC

*OWENS-ILLINOIS INC/KIMBLE GLASS INC

* PANDUIT CORP

*PARKER HANNIFIN CORP/FLUIDCONNECTOR PRODUCTS/PARFLEX DIV

*PARKER HANNIFIN CORP/FLUIDPOWER PRODUCTS/SCHRADER BELLOWS DIV

*PASS \& SEYMOUR/LEGRAND

*PERITEK CORP

*PHARMACIA INC/PHARMACIA BIOTECH INC

*PHILLIPS PETROLEUM CO/PHILLIPS SIXTY-SIX (66) CO/PHILLIPS PLASTICS RESINS

*POLAROID CORP/POLARIZER DIV

*PORTA SYSTEMS CORP

*PRECISION CONNECTOR DESIGNS INC

*PRECISION OPTICAL CO

*PRECISION PAPER TUBE CO

*PRINCO INSTRUMENTS INC

* QUANTUM CHEMICAL CORP/U S I DIV

* QUIKRETE CO

*RACAL-DANA INSTRUMENTS INC

* RAYTHEON CO/SEMICONDUCTOR DIV

* RESEARCH INC

*REXENE CORP/REXENE PRODUCTS CO

*REYNARD CORP

*RIEDE SYSTEMS INC 
*ROCKWELL INTERNATIONAL CORP/ALLEN-BRADLEY CO

* ROLYN OPTICS CO

*SCHLUMBERGER LTD/SCHLUMBERGER WELL SERVICES

*SCHOTT GLASS TECHNOLOGIES INC

*SCIENTIFIC GLASS \&. INSTRUMENTS INC

*SCIENTIFIC INSTRUMENTS INC

*SCIENTIFIC SPECIALTIES SERVICE INC

*SCLAVO INC

* SEAMAN NUCLEAR CORP

*SENCENBAUGH WIND ELECTRIC CO

*SHIMADZU SCIENTIFIC INSTRUMENTS INC

*SIEBE INC/FOXBORO CO

*SPECIAL OPTICS

* SPECIALTY PAPERBOARD INC/PRESSBOARD PRODUCTS DIV

* SPEEDRACK PRODUCTS GROUP LTD

*STRANDBERG ENGINEERING LABORATORIES INC

* SUNDSTRAND CORP/SUNDSTRAND DATA CONTROL/INSTRUMENT SYSTEMS

* SUPREME EQUIPMENT \& SYSTEMS CORP

* SYBRON CORP/NALGE CO

* SYNDEVCO INC

*T D K CORP

*TEAC AMERICA INC

*TEKA INTERCONNECTION SYSTEMS INC

*TEMP-FLEX CABLE INC

*TERADYNE INC/CONNECTION SYSTEMS INC

TEXTRON INC/TEXTRON DEFENSE SYSTEMS/OPTO ELECTRONICS

*THOMAS \& BETTS CORP/ELECTRONICS DIV

*THREE M CO (3M)/OFFICE DOCUMENT SYSTEMS DIV

*TRANSISTOR DEVICES INC

*UEHLING INSTRUMENT CO

*UNISYS CORP/CONVERGENT INC/CONVERGENT TECHNOLOGIES INC

*VACUMET CORP

*VALMET AUTOMATION (USA) INC

*VANCO CONNECTOR CORP

*VIRGINIA PANEL CORP

*VISUAL ELECTRONICS CORP/STACOR CORP

*VOITH INC/PAPER MACHINE EQUIPMENT

* WAger (ROBERT h) CO INC

* WATERS INSTRUMENTS INC

*WHITE STORAGE \& RETRIEVAL SYSTEMS INC

*WINSLOW INC

*WIRE-PRO INC/GARRY ELECTRONICS

*WITCO CORP/HUMKO CHEMICAL DIV

*X-RITE INC

*YUASA EXIDE INC

$* Z$ Y P COATINGS INC

*ZERO CORP/SCANBE 
WHC-SD-TD-RPT-011

Revision 0

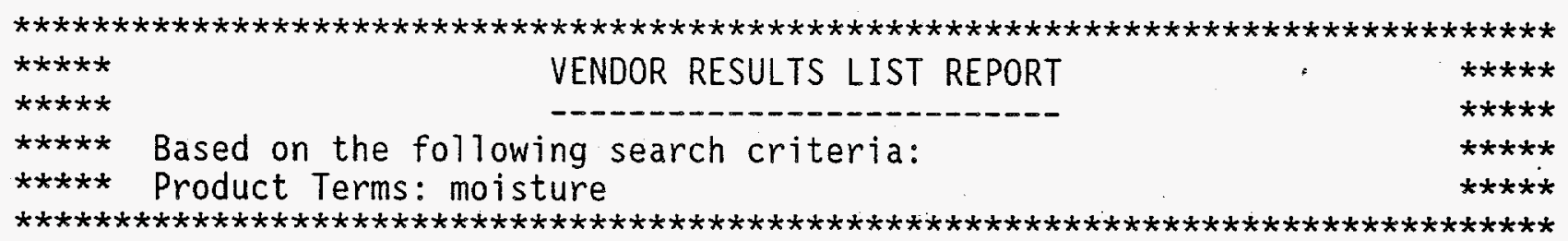

*A I TECHNOLOGY INC

*ABBEY HOME HEALTHCARE

*ADHESIVES RESEARCH INC .

*ADVANCED MOISTURE TECHNOLOGY INC

*AIRCO GASES

*ALLIEDSIGNAL INC/ENGINEERED MATERIALS/SPECIALTY FILMS

*AMERICAN TAR CO

*APPLIED POLYMERS OF AMERICA INC

*AQUA-CHEM INC/CLEAVER-BROOKS DIV

*AQUA MEASURE INSTRUMENT CO/MOISTURE REGISTER PRODUCTS DIV

*ARMSTRONG INTERNATIONAL INC/WARRICK CONTROLS INC

*ATLAS COPCO CONSTRUCTION \& MINING NORTH AMERICA

*B A S F CORP/POLYMERS PLASTIC FOAMS

*B Y K-GARDNER INC

*BALER EQUIPMENT CO

*BEACH FILTER PRODUCTS INC

*BECKMAN INSTRUMENTS INC/BIOANALYTICAL SYSTEMS GROUP

*BEN MEADOWS CO

*BERKSHIRE HATHAWAY INC/SCOTT FETZER CO/ADALET-P L.M

*BERTHOLD SYSTEMS INC

*BRABENDER ( $\mathrm{C}$ W) INSTRUMENTS INC

*BRINKMANN INSTRUMENTS INC

*BROD-DUGAN CO

*CHANCE (A B) CO

*CHEMREX INC/SONNEBORN BUILDING PRODUCTS

*CLIMATRONICS CORP

*COLE HERSEE CO

*COLTENE/WHALEDENT INTERNATIONAL DIV

*COLUMBIA MACHINE INC

*COMPONENTS CORP OF AMERICA/STACOSWITCH INC

*CONSTRUCTION SPECIFICATIONS INSTITUTE INC. (MANUAL OF PRACTICE/MASTERFORMAT)

CONSTRUCTION SPECIFICATIONS INSTITUTE INC (SPECTEXT DIVISIONS 5-8)

CONSTRUCTION SPECIFICATIONS INSTITUTE INC (SPECTEXT DIVISION 16/SPECTEXT II.)

*CONSTRUCTION SPECIFICATIONS INSTITUTE INC (SPEC-DATA/MANU-SPEC)

*CONTROL CORP OF AMERICA

*COSA INSTRUMENT CORP

*COTTRELL PAPER CO INC

*D S M CHEMICALS NORTH AMERICA INC

*DELMHORST INSTRUMENT CO

*DU PONT CO/MAINTENANCE FINISHES

*DURICHLOR 51 ANODE CO

*DURON INC

*E $G \& G$ INC/E G \& G MOISTURE \& HUMIDITY SYSTEMS

*E $G \cdot \&$ G INC/E $G$ \& G ROTRON INDUSTRIAL DIV 
WHC-SD-TD-RPT-011

Revision 0

${ }^{*} E$ G \& G PROCESS MEASUREMENT CHANDLER

*E L E INTERNATIONAL INC/SOILTEST PRODUCTS DIV

*EATON CORP/AEROSPACE CONTROLS DIV

*EATON CORP/CONTROLS DIV

*ELECTROMATIC EQUIPMENT CO INC

*ELLIS/KUHNKE INC

*EMERSON ELECTRIC CO/ALCO CONTROLS DIV

*EMERSON ELECTRIC CO/ROSEMOUNT ANALYTICAL INC

*EMERSON ELECTRIC CO/ROSEMOUNT ANALYTICAL INC (NEW JERSEY)

*EMERSON ELECTRIC CO/ROSEMOUNT INC/KAY-RAY, SENSALL INC

*ENDRESS \& HAUSER INSTRUMENTS

*ENVIROTECH CORP/T N TECHNOLOGIES INC

*ERCONA CORP

* ESSEX GROUP INC/INDUSTRIAL PRODUCTS DIV

*EUCLID CHEMICAL CO

*EUTEK SYSTEMS

*F S I INTERNATIONAL

*FAST HEAT ELEMENT MANUFACTURING CO INC

*FISHER SCIENTIFIC

*FLUID DATA INC

*FORTE TECHNOLOGY INC

*FOSS FOOD TECHNOLOGY CORP

*FOX INDUSTRIES INC

*FUJIKOKI AMERICA INC

* FULLER (H B) CO/FOSTER PRODUCTS CORP

*GENERAL FIBERGLASS SUPPLY INC/EPIC RESINS DIV

*GENERAL KINETICS INC/FOOD TECHNOLOGY. CORP

*GRISWOLD CONTROLS

*GULF STATES ASPHALT CO INC

*GUNNEBO FASTENING CORP

*HAMWORTHY USA INC/EAGLE COMPRESSORS INC

*HASLER-TEL CO INC

*HENRY VALVE CO INC

*HEXCEL CORP/CHEMICAL PRODUCTS DIV, RESIN CHEMICALS GROUP

*HUMBOLDT MANUFACTURING CO

*ILLINOIS TOOL WORKS INC/SIMCO CO INC

* IMO INDUSTRIES INC/AEROPRODUCTS DIV

* INTEL CORP (MICROPROCESSORS/PERIPHERALS)

* INTEL CORP (MEMORIES/PLD/MICROCOMMUNICATIONS/DEV TOOLS)

* INTERNATIONAL E P D M RUBBER ROOFING SYSTEMS. INC

* IRROMETER CO INC

*J \& W SCIENTIFIC INC

* JAMES INSTRUMENTS INC

*KALTEC SCIENTIFIC INC

*KENDALL CO/POLYKEN DIV

*KOEHLER INSTRUMENT CO INC

* LAB GLASS

* LECO CORP

* LEYBOLD VACUUM PRODUCTS INC

* LOCTITE CORP

*LONGYEAR CO/BRAINARD-KILMAN DRILL CO

*LORD CORP/CHEMICAL PRODUCTS DIV 
WHC-SD-TD-RPT-011

Revision 0

* LORENTZEN \& WETTRE U S A INC

* LUCAS AEROSPACE POWER TRANSMISSION CORP

* LUXTRON CORP

*M/K SYSTEMS INC

*MAGNETEK INC/MAGNETEK CONTROLS/B-W CONTROLS

*MALLINCKRODT INC/MALLINCKRODT MEDICAL INC/MALLINCKRODT ANESTHESIA PRODUCTS

*MATHESON GAS PRODUCTS INC

*MEADOWS. (W R) INC

*MET-PRO CORP/DUALL DIV

*METAL GOODS MANUFACTURING CO

*METTLER-TOLEDO INC

*MINERAL INSULATION MANUFACTURERS ASSOCIATION INC

*MISSOURI RESEARCH LABORATORIES INC/HESCO DIV

* NAMCO CONTROLS CORP

*NASHUA CORP/INDUSTRIAL TAPE DIV

*NATIONAL STARCH \& CHEMICAL CORP/ABLESTIK LABORATORIES

*NITTO DENKO CO/PERMACEL

*NOX-CRETE CHEMICALS INC

*OHAUS CORP

*OHMART CORP

*OLIN CORP/CHEMICALS GROUP

*ORION RESEARCH INC

*OTTO ENGINEERING INC/OTTO CONTROLS DIV

*PANAMETRICS INC

*PARAMOUNT INDUSTRIES INC

*PARKER HANNIFIN CORP/FLUIDCONNECTOR PRODUCTS/HOSE PRODUCTS DIV

*PARKER HANNIFIN CORP/FLUIDPOWER PRODUCTS/PNEUMATIC DIV

*PARKER HANNIFIN CORP/REFRIGERATION COMPONENTS GROUP/REFRIGERATION \& AIR CONDITIONING DIV

*PARMATIC FILTER CORP/PARMATIC POLUTION CONTROL CORP

*PENNSYLVANIA SEPARATOR CO

*PERMAGILE INDUSTRIES INC/PERMAGILE EPOXIES DIV

*PERRY EQUIPMENT CORP

*PHILLIPS PETROLEUM CO/PHILLIPS FIBERS CORP

*PIONEER AIR SYSTEMS INC

*PNEUMATIC PRODUCTS CORP

*POLYMERIC SYSTEMS INC

*PREMIER INDUSTRIAL CORP/WESTERN FIRE EQUIPMENT CO

*QUINN (K J) \& CO INC

$* R$ \& D SEPARATIONS INC

*R P M INC/CARBOLINE CO, SUBOX DIV

*RETAWMATIC CORP

*REYNOLDS INDUSTRIES INC

* RICHMOND TECHNOLOGY INC

*SCHOEN INDUSTRIES INC/RESIST-A-CHEM INC

* SCHULLER INTERNATIONAL INC/MANVILLE ROOFING SYSTEMS DIV

*SCIENTIFIC GLASS \& INSTRUMENTS INC

*SCOTT SPECIALTY GASES INC

*SEALANT/WATERPROOFING \& RESTORATION INSTITUTE (SWRI)

* SEAMAN NUCLEAR CORP

*SHERWIN-WILLIAMS CO/STORES DIV/PROFESSIONAL COATINGS DEPT

*SIEBE INC/BARBER-COLMAN CO, AEROSPACE \& POWER CONTROLS.DIV 
WHC-SD-TD-RPT-011

Revision 0

*SIEBE INC/FOXBORO CO

*SIERRA-MISCO INC

*SOLAR COMPOUNDS CORP

*SPARTON CORP/SPARTON TECHNOLOGY INC

*SPORLAN VALVE CO

*STANADYNE AUTOMOTIVE CORP/DIESEL SYSTEMS DIV

*STARKEY LABORATORIES

*STEELCOTE MANUFACTURING CO

*STEINEN (W M) MANUFACTURING CO/MC INTIRE CO

*STO-COTE PRODUCTS INC

*STRANDBERG ENGINEERING LABORATORIES INC

*SYMPLASTICS INC

*T S I INC/HANDAR INC

*TED MANUFACTURING CORP

*TELEDYNE INC/TELEDYNE ANALYTICAL INSTRUMENTS

*TEXMASTIC INTERNATIONAL INC

*TORO CO/IRRIGATION DIV

*UNION CAMP CORP/CONTAINER DIV

*VACUUM/ATMOSPHERES CO

* VALMET AUTOMATION (USA) INC

* VALSPAR CORP/MC CLOSKEY DIV

*VECTOR CORP

*VELCRO U S A INC

*WATROUS \& CO INC

*WHITE (DAVID) INC

*WIREKRAFT

*WITCO CORP/KENDALL REFINING CO

*ZURN INDUSTRIES INC/GENERAL AIR DIV 
WHC-SD-TD-RPT-011

Revision 0

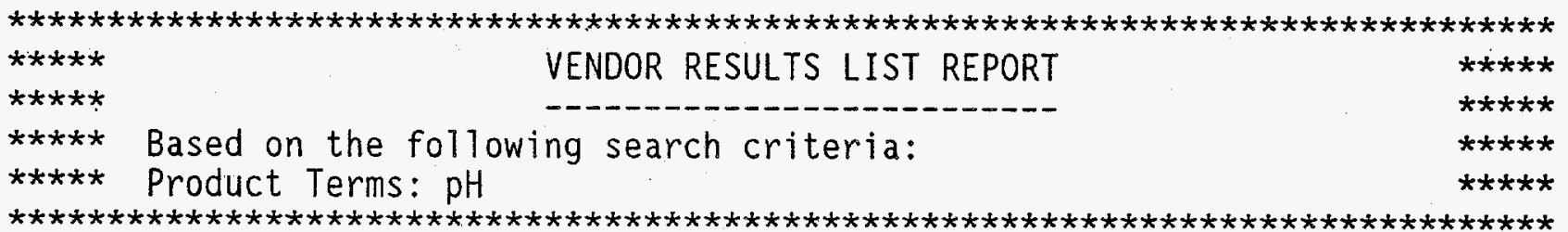

*A $F$ L INDUSTRIES INC

*A S E A BROWN BOVERI INC/A B B KENT-TAYLOR

*A T S SALES INC/WATER KING DIV

*A V L SCIENTIFIC CORP

*ALDOA CO

*ALPHA-M CORP

*ANALOGIC CORP/MEASUREMENT \& CONTROL DIV

*ARMCO INC

*ARTESIAN WATER CONDITIONING INC

*B Y K-GARDNER INC

*BAILEY CONTROLS CO

*BAKER HUGHES INC/BAKER HUGHES DRILLING EQUIPMENT/MILPARK DRILLING FLUIDS

*BARNANT CO

*BECKMAN INSTRUMENTS INC/BIOANALYTICAL SYSTEMS GROUP

*BEN MEADOWS CO

*BERNITE PRODUCTS INC

*BETZ ENERGY CHEMICALS INC

*BRINKMANN INSTRUMENTS INC

*CAPITAL CONTROLS CO INC

*CARPENTER TECHNOLOGY CORP/CARPENTER STEEL DIV

*CHEM SERVICE INC

*CIBA-CORNING DIAGNOSTICS CORP/GILFORD SYSTEMS

*CINE MAGNETICS INC/F R CHEMICALS DIV

*COLE-PARMER INSTRUMENT CO

*COMMERCIAL INTERTECH CORP/CUNO INC, PROCESS FILTRATION PRODUCTS

*CONOPTICS INC

*CONTROL TECHNIQUES/E C S

*COROMETRICS MEDICAL SYSTEMS INC

*CRANE CO/COCHRANE ENVIRONMENTAL SYSTEMS

*DEVAR INC/CONTROL PRODUCTS DIV

*DIEDRICH TECHNOLOGIES INC

*DU -PONT CO/PETROCHEMICALS

*E I T

*E L E INTERNATIONAL INC/SOILTEST PRODUCTS DIV

*ELECTROCHEMICALS INC

*EMERSON ELECTRIC CO/ROSEMOUNT ANALYTICAL INC (NEW JERSEY)

*EXTECH INSTRUMENTS CORP

* FISCHER \& PORTER CO

*FISHER SCIENTIFIC

* FISHER SCIENTIFIC CO/EDUCATIONAL MATERIALS DIV

$*_{G} F$ S CHEMICALS INC

*GALLARD-SCHLESINGER INDUSTRIES INC

*GAM RAD INC/GAM RAD WEST INC 
WHC-SD-TD-RPT-011

Revision 0

*GARDINER METAL CO/GARDINER SOLDER CO

*GENERAL SIGNAL CORP/LEEDS \& NORTHRUP

*GEORGE FISCHER CORP/GEORGE FISCHER SIGNET INC

*GEORGIA-PACIFIC CORP/GEORGIA-PACIFIC RESINS INC

*H N U SYSTEMS INC

* HARCO TECHNOLOGIES CORP

*HASLER-TEL CO INC

*HEATBATH CORP

*HONEYWELL INC/MICRO SWITCH DIV

*HORIBA INSTRUMENTS INC

*HUMBOLDT MANUFACTURING CO

*I $C \cdot N$ PHARMACEUTICALS INC/I C N BIOMEDICALS INC

*INTERNATIONAL DIOXCIDE INC

* JOHNSON YOKOGAWA CORP

* LIQUID CARBONIC

* LONDON CHEMICAL CO INC

*MALLINCKRODT INC/MALLINCKRODT SPECIALTY CHEMICALS CO/PERFORMANCE \& LABORATQRY CHEMICALS

*MARK IV INDUSTRIES INC/L F E INSTRUMENTS

*MERCK \& CO INC/CALGON CORP

*MET-PRO CORP/DEAN PUMP DIV

*MICRO ESSENTIAL LABORATORY INC.

*MIDWEST AIR PRODUCTS CO

*MYRON L CO

*NEWPORT ELECTRONICS INC

* NORCROSS CORP

*OMEGA ENGINEERING INC

*ORION RESEARCH INC

*P S E INTERNATIONAL INC

*PARKER SYSTEMS INC

*PENNSYLVANIA SEPARATOR CO

*PLATING RESOURCES INC

*POLYSCIENCES INC

*PREMIER SERVICES CORP

*PRESTO-TEK CORP

*PRO SO ${ }^{\circ}$ CO INC

*PROMEGA CORP

*PULSAFEEDER INC/MORR CONTROL

*RICGA CHEMICAL CO

*RONTONICS MFG INC/RMI-P/PLASTECH

*ROYCE INSTRUMENTS CORP

*SCHOTT CORP/GREAT LAKES INSTRUMENTS INC

*SEA-BIRD ELECTRONICS INC

*SERFILCO LTD

* SIEBE INC/FOXBORO CO

* SNAP-TITE INC/VALVE DIV

*SPECTRUM CHEMICAL MANUFACTURING CORP

*STEELCOTE MANUFACTURING CO

*STETCO INC

*STETSON (M D) CO

*SUNDSTRAND CORP/MILTON ROY CO/LIQUID METRONICS INC

*SUNDSTRAND CORP/SULLAIR CORP 
WHC-SD-TD-RPT-011

Révision 0

* SUPERIOR TUBE co

*T B I-BAILEY CONTROLS CO

*T M ANALYTIC INC

*TECHNIC INC

*V W R CORP $/ V W R$ SCIENTIFIC

*VARIAN ASSOCIATES INC/INSTRUMENT GROUP

*VIRTIS CO INC

* WALCHEM CORP

*WATER RESOURCES INTERNATIONAL INC

* WHATMAN INC

*WHEATON INDUSTRIES/WHEATON DIV

*WITCO CORP/ALLIED-KELITE DIV

*WORLD PRECISION INSTRUMENTS INC

*YELLOW SPRINGS INSTRUMENT CO INC. 
*MICROMERITICS INSTRUMENT CORP

*MOTT METALLURGICAL CORP

*OSMONICS INC

*RADIAC ABRASIVES

*S S I TECHNOLOGIES INC

*SCHLUMBERGER LTD/SCHLUMBERGER WELL SERVICES

*TELEDYNE INC/TELEDYNE GURLEY

*TESTING MACHINES INC 
WHC-SD-TD-RPT-011

Revision 0

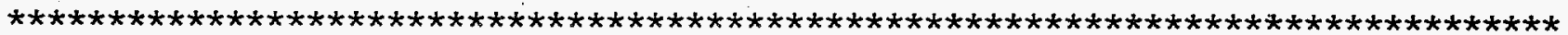

*BRABENDER ( $\mathrm{C}$ W) INSTRUMENTS INC

*METTLER-TOLEDO INC

*MORTON INTERNATIONAL INC/SPECIALTY CHEMICALS GROUP

*RHEOMETRICS INC

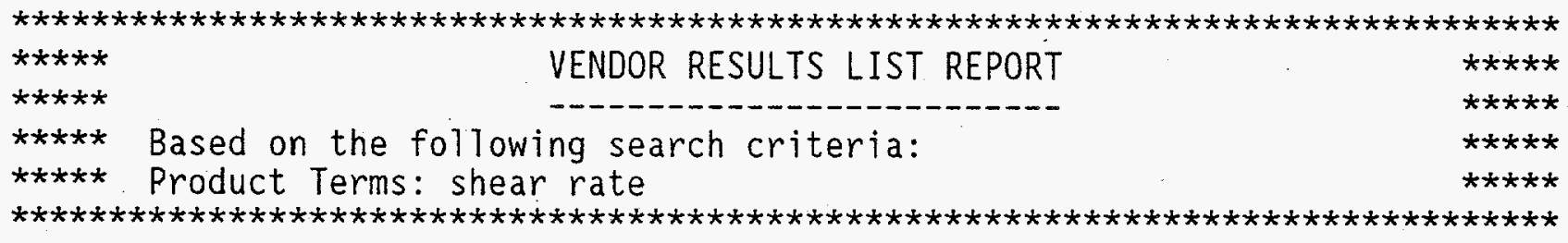

*ALLIEDSIGNAL. INC/ALLIEDSIGNAL AEROSPACE CO/GUIDANCE-SYSTEMS DIV/BENDIX CHESHIRE OPNS

\begin{tabular}{|c|c|c|c|}
\hline$* \star * * *$ & & VENDOR RESULTS LIST REPORT & $* * * * *$ \\
\hline 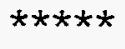 & & --- - - - - - - - - - - - - - - - - - - & $\star \star \star \star \star *$ \\
\hline$\star \star \star * \star *$ & Based on the followi & ng search criteria: & $\star * * * *$ \\
\hline$\star \star \star \star \star * ~$ & Product Terms: shear & strength & 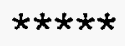 \\
\hline
\end{tabular}

*E L E INTERNATIONAL INC/SOILTEST PRODUCTS DIV

\begin{tabular}{|c|c|c|}
\hline$\star \star \star \star \star ~$ & VENDOR RESULTS LIST REPORT & 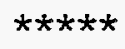 \\
\hline 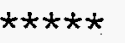 & 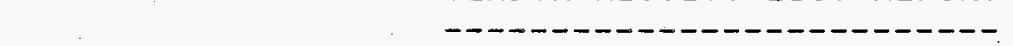 & 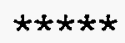 \\
\hline $\begin{array}{l}\star \star \star \star \star * \\
\star \star \star \star \star *\end{array}$ & Based on the following search criteria: & $\begin{array}{l}\star * \star * * \\
\star * \star * *\end{array}$ \\
\hline
\end{tabular}

*BISON INSTRUMENTS INC 
WHC-SD-TD-RPT-011

Revision 0

\begin{tabular}{|c|c|c|}
\hline$\star * * * *$ & VENDOR RESULTS LIST REPORT & $\star \star \star \star * \star$ \\
\hline$\star \star * * * *$ & 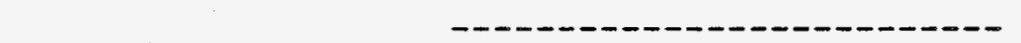 & $* * * * *$ \\
\hline$\star \star * \star * *$ & Based on the following search criteria: & 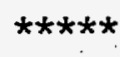 \\
\hline$* * * * *$ & Product Terms: stress & $\star * * * *$ \\
\hline
\end{tabular}

*AKZO AMERICA INC/AKZO COATINGS INC

*ALGOMA STEEL INC

*AMERACE CORP/ELASTIMOLD PRODUCTS

*APPLIED TEST SYSTEMS INC

*BERKSHIRE HATHAWAY INC/SCOTT FETZER CO/ADALET-P L M

*BRUEL \& KJAER INSTRUMENTS INC

*CARPENTER TECHNOLOGY CORP/CARPENTER STEEL DIV

*CHARIS CORP

*CLARK-RELIANCE CORP/JACOBY-TARBOX DIV

*COLLINS (WARREN E) INC

*DEKTOR COUNTER-INTELLIGENCE \& SECURITY INC

*DEPOSITION SCIENCES INC

*DORLEC CORP

*DU PONT CANADA INC/PLASTICS DIV

*EATON CORP/ENGINEERED FASTENERS DIV

*EATONCARE TELEMETRY INC

*ELECTROCOM/GARD LTD

*FEL-PRO CHEMICAL. PRODUCTS L P

*FLUXATRON SYSTEMS INTERNATIONAL

*FREEMAN MANUFACTURING CO

*GAERTNER SCIENTIFIC CORP

*GENERAL SIGNAL CORP/BLUE M ELECTRIC

*GENRAD INC/STRUCTURAL TEST PRODUCTS

*H B M INC

*HARVARD INDUSTRIES INC/ELASTIC STOP NUT DIV

* HAWARD CORP

* INDEPENDENT TESTING LABORATORIES INC

* INTERNATIONAL PAPER/WOOD PRODUCTS DIV

*K S AVIONICS INC

*KULITE SEMICONDUCTOR PRODUCTS INC

* LA BELLE INDUSTRIES INC/QUEST TECHNOLOGIES

* LITTON INDUSTRIES INC/LITTON POLY-SCIENTIFIC/SLIP RING PRODUCTS

*MAC NEAL-SCHWENDLER CORP

*MAXWELL LABORATORIES INC/S-CUBED DIV

*MECHANICAL TECHNOLOGY INC/L A B

*MECHANICAL TECHNOLOGY INC/LING ELECTRONICS INC

*MONMOUTH PLASTICS INC

*OMEGA ENGINEERING INC

$* P P$ G INDUSTRIES INC/COATINGS \& RESINS

*PLYMOUTH RUBBER CO INC/PLYMOUTH/BISHOP INSULATING PRODUCTS

*POLYGON CO

*POLYMER LABORATORIES INC/THERMAL SCIENCES DIV

*PRICE BROTHERS CO 
WHC-SD-TD-RPT-011

Revision 0

*PUBLICKER INDUSTRIES INC/ASSOCIATED TESTING LABORATORIES

*RAWLPLUG CO INC

*RELIANT HEATING \& CONTROLS INC

* RESEARCH INC

*ROCTEST INC

*RUDOLPH INSTRUMENTS INC

*SATEC SYSTEMS INC

* SIGMA TEST LABORATORIES

*SLOPE INDICATOR CO

*SOLTEC CORP

*SOLTEC CORP/KYOWA PRODUCTS DIV

*SOUTHERN PINE INSPECTION BUREAU (SPIB)

*STOELTING CO

*STRESS RELIEF ENGINEERING CO

*T E C

*TELEDYNE INC/TELEDYNE BROWN ENGINEERING

*TELEDYNE INC/TELEDYNE BROWN ENGINEERING/TELEDYNE ENGINEERING SERVICES DIV

*TELEDYNE PITTSBURGH TOOL STEEL

*U S NATURAL RESOURCES INC/IRVINGTON-MOORE FOREST PRODUCTS DIV

*UNION METAL CORP

$* V S \cdot R$ INC

*VALLEN CORP/ENCON SAFETY PRODUCTS

*VENTUREDYNE LTD/THERMOTRON INDUSTRIES

*VISHAY INTERTECHNOLOGY INC/MEASUREMENTS GROUP INC

*WESTERN WOOD PRODUCTS ASSOCIATION (WWPA) 
WHC-SD-TD-RPT-011

Revision 0

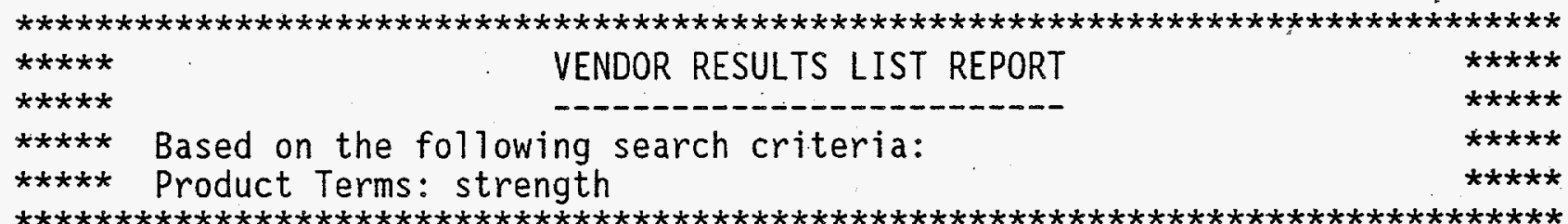

*A $\vee O$ INTERNATIONAL

*AIMSCO INC

*ALGOMA STEEL INC

*AMERICAN CYANAMID CO/D AIRCRAFT PRODUCTS INC

*AMERICAN PREMIER INC/PREMIER REFRACTORIES \& CHEMICALS INC

*AMETEK INC/MANSFIELD \& GREEN. DIV

*ANDO CORP

*ANRITSU WILTRON SALES CO

*ANTENNA RESEARCH ASSOCIATES INC

*APPLIED TEST SYSTEMS INC

*ARDROX INC

*ARNCO INC

*ASSOCIATED RESEARCH INC

*ASSOCIATED STEEL CORP

*ATLAS WIRE \& CABLE CORP

*AUTO-METRICS INC

*AVDEL CORP

*AVTRON MANUFACTURING INC

*B A S F CORP/POLYMERS PLASTIC FOAMS

$* B$ L H ELECTRONICS INC

*BATSON (LOUIS P) INC

*BETHLEHEM STEEL CORP

*BIACH INDUSTRIES INC

*BLACK \& DECKER CORP/POP FASTENERS DIV

*BLONDER-TONGUE LABORATORIES INC

*BRINKMANN INSTRUMENTS INC

*CADY (E J) \& CO

*CASTALL INC

*CENTRAL STEEL \& WIRE CO

*CHATILLON (JOHN) \& SONS INC/FORCE MEASUREMENT DIV

*CHATSWORTH DATA CORP

*COAXIAL DYNAMICS INC

*COLE-PARMER INSTRUMENT CO

*COLONIAL PRINTING INK CORP

*COMMUNICATIONS MANUFACTURING CO

*COMSONICS INC

*COMTEN INDUSTRIES INC

*CRITERION INSTRUMENTS LTD/CANADIAN RESEARCH INSTITUTE

*CRUCIBLE MATERIALS CORP/CRUCIBLE SPECIALTY METALS DIV

${ }^{*}$ CYCLOPS INDUSTRIES INC/CYTEMP SPECIALTY STEEL

*D E S C O INDUSTRIES INC

*DANIELS MANUFACTURING CORP

*DAYTON-GRANGER INC

*DUDICK INC/CORROSION-PROOF PRODUCTS

*E E V INC 
WHC-SD-TD-RPT-011

Revision 0

*E L E INTERNATIONAL INC/SOILTEST PRODUCTS DIV

*ECOLOTROL INC

*ELECTROMATIC EQUIPMENT CO INC

*EMERSON ELECTRIC CO/ROSEMOUNT ANALYTICAL INC (NEW JERSEY)

*EUCLID CHEMICAL CO

*FAIRCHILD CORP/FAIRCHILD FASTENER GROUP/AEROSPACE FASTENER DIV, 'TRIDAIR

PRODUCTS

*FALEX CORP

*FARGO CO

*FIVE STAR PRODUCTS INC

*FOX INDUSTRIES INC

*FREUDENBERG-NOK

*FULLER (H B) CO

*G S E INC/MEASUREMENT \& CONTROL

*GENERAL ELECTRIC CO/G E SILICONES

*GEORGIA-PACIFIC CORP/GEORGIA-PACIFIC RESINS INC

*GOODRICH (B F) CO/SUPER-TEMP

*H B D INDUSTRIES INC/THERMOID

*HARSCO CORP/PATTERSON-KELLEY CO/ASTRALLOY WEAR TECHNOLOGY DIV

*HASLER-TEL CO INC

*HENKEL CORP/PAPER CHEMICALS

*HEWLETT-PACKARD CO

*HIPOTRONICS INC

* HOLADAY INDUSTRIES INC

*HORTON MANUFACTURING CO INC

*HUMBOLDT MANUFACTURING CO

*I L C INDUSTRIES INC/I L C DOVER INC

* INLAND STEEL INDUSTRIES INC/INLAND STEEL CO

*INLAND STEEL INDUSTRIES INC/RYERSON (JOSEPH T) \& SON INC

*INLAND STEEL INDUSTRIES INC/TULL (J M) METALS CO INC

* INSTRON CORP

*ION TRACK INSTRUMENTS INC/I T I INDUSTRIAL

*JORGENSEN STEEL \& ALUMINUM

*KEYTEK INSTRUMENT. CORP

*KING NUTRONICS CORP

*KOBE STEEL U S A INC

*KOCH INDUSTRIES INC/KOCH CORROSION CONTROL CO

*KOEHLER INSTRUMENT CO INC

*L T $\vee$ CORP/L T $\vee$ STEEL CO

* L T V CORP/L T V STEEL TUBULAR PRODUCTS CO

*LA PORTE CONSTRUCTION CHEMICALS NORTH AMERICA INC/TAMMS INDUSTRIES CO

* LEE CO

* LOCTITE CORP

*LORENTZEN \& WETTRE U S A INC

* LUKENS INC/LUKENS STEEL CO

*M T S SYSTEMS CORP

*METRIC \& MULTISTANDARD COMPONENTS CORP

*METROX INC

*MICRO INSTRUMENT CO

*MODERN CONTROLS INC

*MORRISON MOLDED FIBER GLASS CO/A F C DIV

* $\mathrm{N} \mathrm{K} \mathrm{K} \mathrm{AMERICA} \mathrm{INC/STEEL} \mathrm{DIV}$ 
WHC-SD-TD-RPT-011

Revision 0

*NATIONAL LIME ASSOCIATION (NLA)

* NATIONAL STONE ASSOCIATION (NSA)

*NEW HAMPSHIRE BALL BEARINGS INC

*NIPPON STEEL U S A INC

*OCCIDENTAL PETROLEUM CORP/OCCIDENTAL CHEMICAL CORP/DUREZ DIV

*OLIN CORP/OLIN BRASS GROUP

*OLSEN (TINIUS) TESTING MACHINE CO INC

*OMEGA ENGINEERING INC

*PACCAR INC/DYNACRAFT CO

*PACIFIC SCIENTIFIC CO/H T L, KIN-TECH DIV

*PARKER (A T) INC/SOLAR ELECTRONICS CO

*PARR INSTRUMENT CO

*PENRIL DATACOMM NETWORKS INC/ELECTRO-METRICS

*PERMAGILE INDUSTRIES INC/PERMAGILE EPOXIES DIV

*POLYMER CORP (THE)

*POTOMAC INSTRUMENTS INC

*QUANEX CORP/QUANEX LA SALLE STEEL

*QUANTACHROME CORP

* $R$ M I TITANIUM CO

*RELIANCE ELECTRIC CO/DODGE DIV

*REXENE CORP/REXENE PRODUCTS CO

*REXROTH CORP/PNEUMATICS DIV

*ROHDE \& SCHWARZ INC/MEASUREMENT EQUIPMENT

*SATEC SYSTEMS INC

* SAUERE ISEN

*SCHAFFNER E M C INC

*SHEFFIELD PLASTICS INC

*SMISER INDUSTRIES INC

*STANDEX INTERNATIONAL CORP/STANDEX PRECISION ENGINEERING/PERKINS (B F) DIV

*STELCO INC

*SUPERIOR alLOY STEEL CO

* SYMONS CORP

*SYSTEMATION ENGINEERED PRODUCTS INC

*T A C C INTERNATIONAL CORP

*T S K AMERICA INC

*TELEDYNE INC/TELEDYNE INDUSTRIES INC/TELEDYNE ALLVAC-VASCO MARKETING

*TENSITRON INC

*TESTING MACHINES INC

*THERMOSET PLASTICS INC

*THWING-ALBERT INSTRUMENT CO

*TIMKEN CO/LATROBE STEEL CO

*U S TSUBAKI INC

*UNITED WESTERN TECHNOLOGIES CORP/SHURTRONICS CORP

*UNOCAL CORP/POCO GRAPHITE INC

*VON CORP

*WACKER SILICONES CORP

* WAGNER INSTRUMENTS

*WAVETEK CORP

*WEST COAST RESEARCH CORP

*WESTERN ATLAS INTERNATIONAL INC/CORE LABORATORIES INSTRUMENTS

*WOODHEAD INDUSTRIES INC/DANIEL WOODHEAD CO

*WROUGHT WASHER MANUFACTURING INC 
WHC-SD-TD-RPT-011

Revision 0

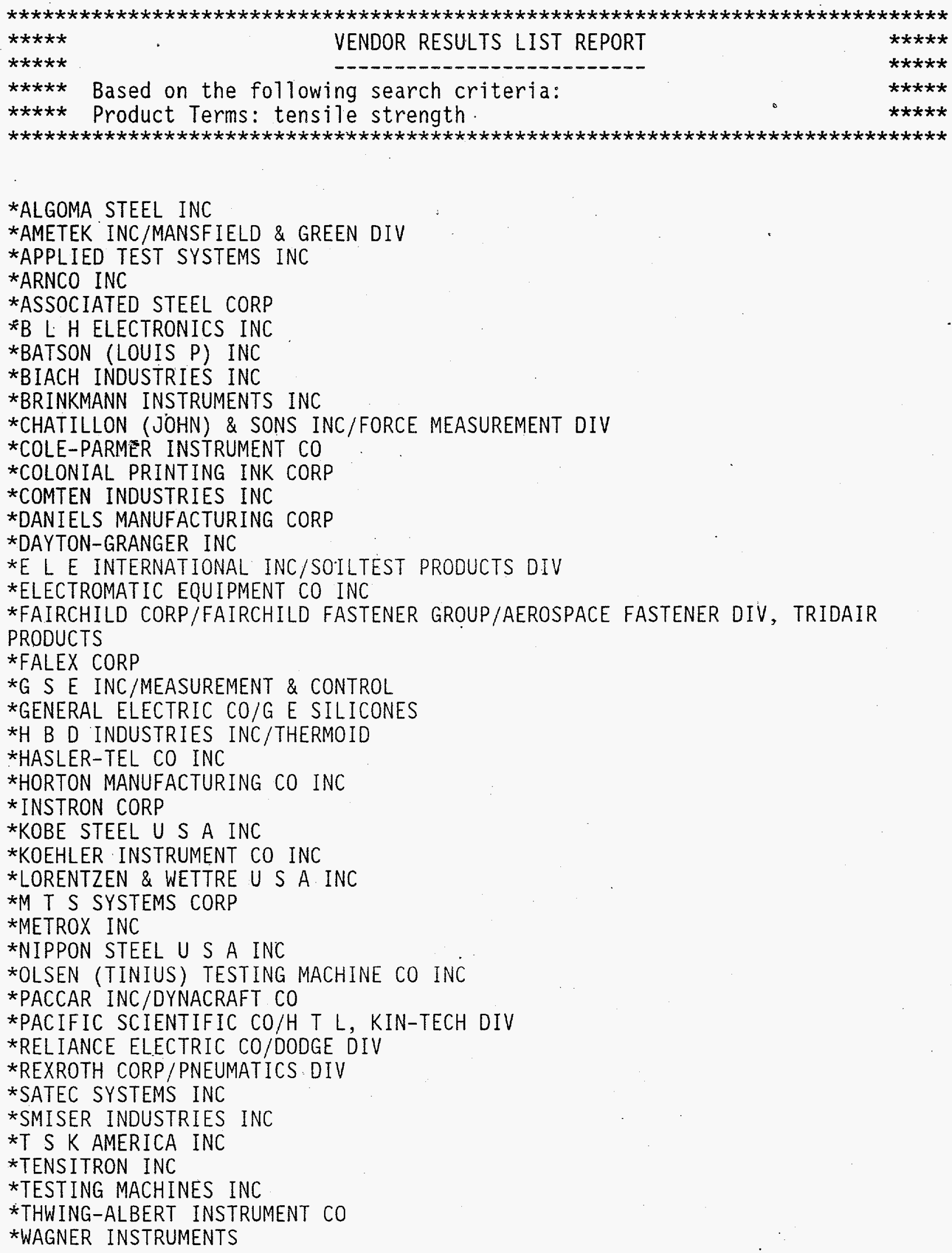


WHC-SD-TD-RPT-011

Revision 0

*WEST COAST RESEARCH CORP

*WESTERN ATLAS INTERNATIONAL INC/CORE LABORATORIES INSTRUMENTS

*WOODHEAD INDUSTRIES INC/DANIEL WOODHEAD CO 
WHC-SD-TD-RPT-011

Revision 0

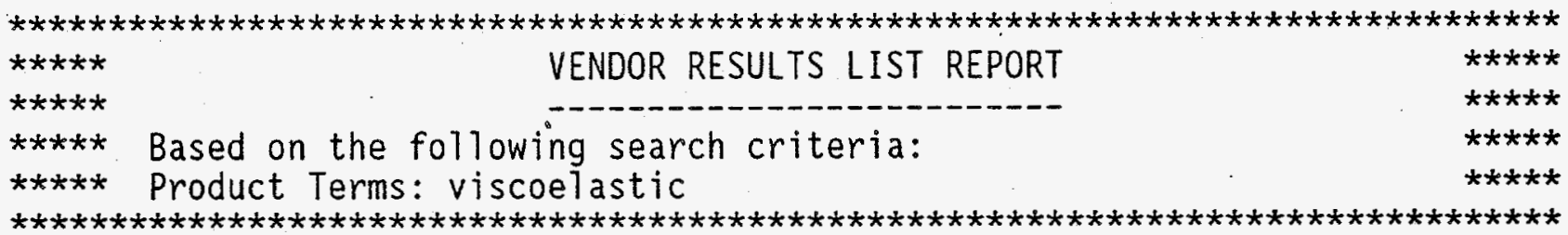

*NAMETRE CO

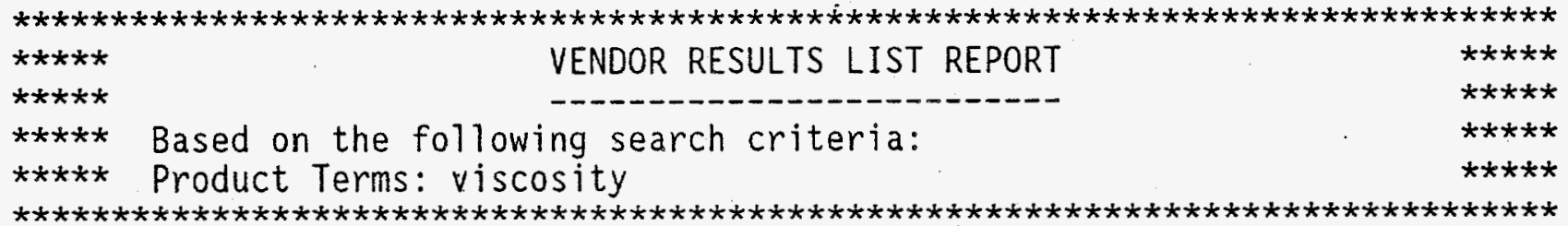

*AMERICAN CYANAMID CO/D AIRCRAFT PRODUCTS INC

*AMETEK INC/MANSFIELD \& GREEN DIV

*AMOCO CORP/AMOCO OIL CO/LUBRICANTS BUSINESS UNIT

*B/R INSTRUMENT CORP

*B Y K-GARDNER INC

*BARNANT CO

*BAROID CORP/BAROID DRILLING FLUIDS INC

*BRABENDER ( $C$ W) INSTRUMENTS INC

*BRINKMANN INSTRUMENTS INC

*BROOKFIELD ENGINEERING LABORATORIES INC

*C S D TECH INTERNATIONAL INC

*CABOT CORP/CAB-0-SIL DIV

*CANNON INSTRUMENT CO

*CARGILLE (R P) LABORATORIES INC

*COLE-PARMER INSTRUMENT CO

*CONAMETER CORP

*COOKSON AMERICA INC/ALPHA METALS INC

*DU PONT CO/PETROCHEMICALS

*E L E INTERNATIONAL INC/SOILTEST PRODUCTS DIV

*EMERSON ELECTRIC CO/ROSEMOUNT INC/ROSEMOUNT ANALYTICAL INC/TEKMAR CO

*ENGELHARD CORP

*EXTECH INSTRUMENTS CORP

*FALEX CORP

*FIKE CORP/FIKE METAL PRODUCTS

*FISHER SCIENTIFIC

*FISONS INSTRUMENTS

*FLUID DATA INC

*FOX INDUSTRIES INC

*FRANGIBLE DISCS INC

*FULLER (H B) CO

*GRAYMILLS CORP 
WHC-SD-TD-RPT-011

Revision 0

*HENKEL CORP/EMERY GROUP

*HENKEL CORP/PAPER CHEMICALS

*HUBER ( $\mathrm{J} \mathrm{M}$ ) CORP/CHEMICALS DIV

*HUMBOLDT MANUFACTURING CO

*HURLETRON INC

*I T T CORP/I T T FLUID TECHNOLOGY CORP/BARTON INSTRUMENTS CO

*KALTEC SCIENTIFIC INC

*KOBOLD INSTRUMENTS INC

*KOEHLER INSTRUMENT CO INC

*LAB GLASS

* LAB-LINE INSTRUMENTS INC

* LEYBOLD VACUUM PRODUCTS INC

* LOCTITE CORP

* LONZA INC

*MERCK \& CO INC/CALGON CORP

*MONA INDUSTRIES INC

*MORTON INTERNATIONAL INC/SPECIALTY CHEMICALS GROUP

*MYERS ENGINEERING INC

${ }^{*} N$ L INDUSTRIES INC/R H E $O X X$ INC

*NAMETRE CO

*NATIONAL STARCH \& CHEMICAL CORP/ABLESTIK LABORATORIES

*NORCROSS CORP

*NORDSON CORP/FINISHING EQUIPMENT

*NORDSON CORP/PACKAGING PRODUCTS \& ASSEMBLY

*NUSIL TECHNOLOGY

*PAINT CHEMICALS INC

*RHONE-POULENC INC/RHONE-POULENC INDUSTRIAL DIV

*RUETGERS-NEASE CHEMICAL CO INC

*RUSKA INSTRUMENT CORP

*SCIENTIFIC GLASS \& INSTRUMENTS INC

*SHELL OIL CO

*SHIMADZU SCIENTIFIC INSTRUMENTS INC

*SPECIALTY ORGANICS INC

*STANCHEM INC

*STEPAN CO

*SUNDSTRANO CORP/MILTON ROY CO/LIQUID METRONICS INC

*UIC INC

*UNION CARBIDE CORP/AMERCHOL CORP

*UNION INK CO INC

*WESTERN ATLAS INTERNATIONAL INC/CORE LABORATORIES INSTRUMENTS

*WITCO CORP/ORGANICS DIV 
WHC-SD-TD-RPT-011

Revision 0:

\section{APPENDIX F. \\ SELECTED VENDORS FROM CD-ROM MASTER VENDOR CATALOG SEARCH FOR PHYSICAL PARAMETERS OF TANK WASTE}

Reproduced from Information Handling Services.

Vendor Master Directory. Mar-Apr 1994 Issue.

Tue Nov 02 07:03:52 1993

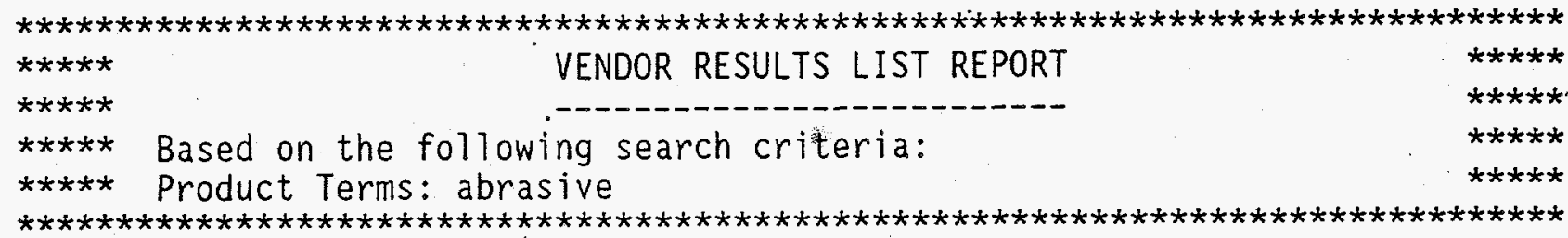

*ABRASIVE INDUSTRIES INC/BAY STATE ABRASIVE PRODUCTS

*ALLISON ABRASIVES INC

*BATES ABRASIVE PRODUCTS INC

*CARBORUNDUM ABRASIVES NORTH AMERICA

*CINCINNATI MILACRON INC/CINCINNATI MILACRON RESIN ABRASIVES

*DAYTON ABRASIVE PRODUCTS CO

*GENERAL ELECTRIC CO/G E SUPERABRASIVES

* LITTON INDUSTRIES INC/LITTON INDUSTRIAL AUTOMATION/DISC GRINDERS \& ABRASIVES

*NORTON CO/ABRASIVES MARKETING GROUP

*PRECISION PROFILES INC

*PRES-ON PRODUCTS INC/PRES-ON ABRASIVES DIV

*RADIAC ABRASIVES

*THREE M CO (3M)/THREE M ABRASIVE SYSTEMS DIV

*TREIBACHER (U S A) CORP/GENERAL ABRASIVE TREIBACHER INC

*UNITED ABRASIVES INC

*UNIVERSAL SUPERABRASIVES/METAL \& INDUSTRIAL GRINDING DIV

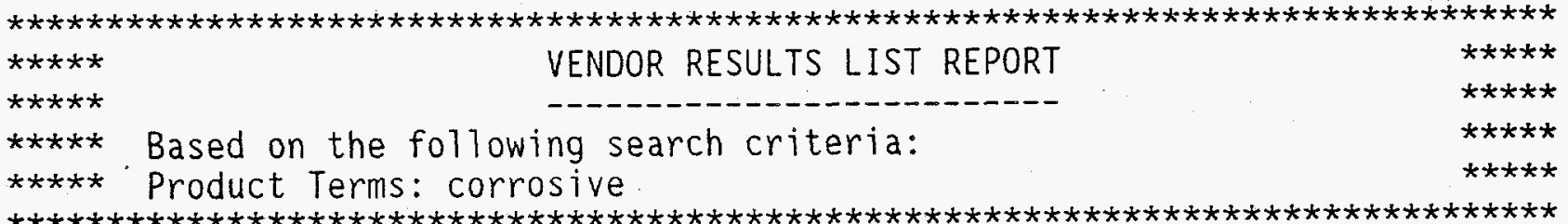

*AALBORG INSTRUMENTS \& CONTROLS INC

*ARMSTRONG INTERNATIONAL INC

*CHEM-TEC EQUIPMENT CO INC

*COLTEC INDUSTRIES INC/DELAVAN ELECTRONICS, PROCESS INSTRUMENTATION OPERATION

*DRESSER INDUSTRIES INC/INDUSTRIAL INSTRUMENT OPERATIONS

* I T T CORP/I T T FLUID TECHNOLOGY CORP/I T T CONOFLOW

*MALLINCKRODT INC/MALLINCKRODT SPECIALTY CHEMICALS CO/PERFORMANCE \& LABORATORY CHEMICALS

*NU-TECH PRECISION METALS (U S A) INC

*TELEDYNE INC/TELEDYNE HASTINGS-RAYDIST 
WHC-SD-TD-RPT-011

Revision 0

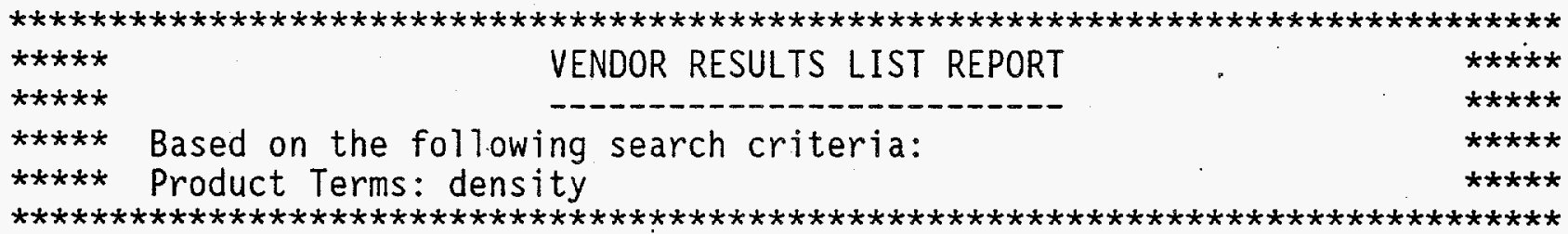

*ASHLAND OIL INC/ASHLAND CHEMICAL INC/THERMOPLASTIC SERVICES DIV

*BIO-RAD LABORATORIES

*BRINKMANN INSTRUMENTS INC

*BROOKLYN THERMOMETER CO INC

*E G \& G INC/E G \& G SPECIAL PROJECTS

*E L E INTERNATIONAL INC/SOILTEST PROQUCTS DIV

*RESEARCH INC

*SCIENTIFIC SPECIALTIES SERVICE INC

* SEAMAN NUCLEAR CORP

*SUNDSTRAND CORP/SUNDSTRAND DATA CONTROL/INSTRUMENT SYSTEMS

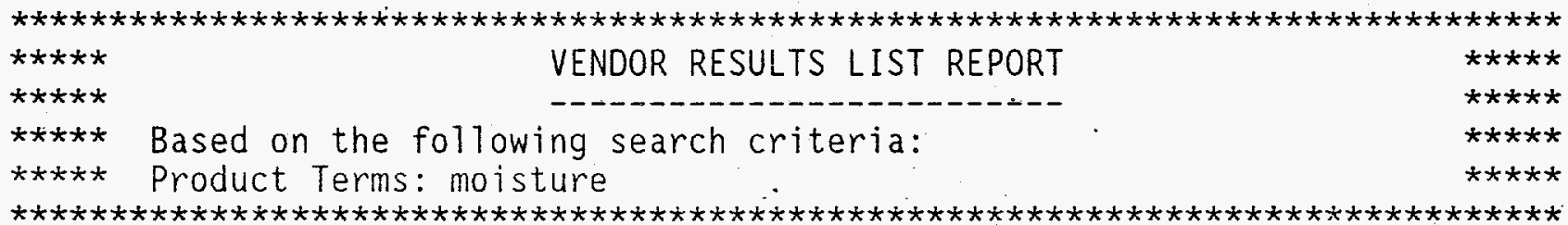

*ADHESIVES RESEARCH INC

*AQUA MEASURE INSTRUMENT CO/MOISTURE:REGISTER PRODUCTS DIV

*BRINKMANN INSTRUMENTS INC

*E G \& G INC/E G \& G MOISTURE \& HUMIDITY SYSTEMS

*E L E INTERNATIONAL INC/SOILTEST PRODUCTS DIV

*FLUID DATA INC

*MISSOURI RESEARCH LABORATORIES INC/HESCO DIV

*PHILLIPS PETROLEUM CO/PHILLIPS FIBERS CORP

*SEALANT/WATERPROOFING \& RESTORATION INSTITUTE (SWRI)

*SEAMAN NUCLEAR CORP

\begin{tabular}{|c|c|c|}
\hline$\star * * * *$ & VENDOR RESULTS LIST REPORT & $\star * * * *$ \\
\hline$\star \star \star \star \star \star *$ & 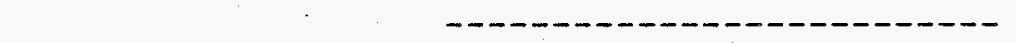 & 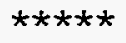 \\
\hline $\begin{array}{l}\star \star \star \star \star \star ~ \\
\star \star \star \star \star *\end{array}$ & $\begin{array}{l}\text { Based on the following search criteria: } \\
\text { Product Terms: } \mathrm{pH}\end{array}$ & $\begin{array}{l}* * * \star * \\
\star * \star * \star *\end{array}$ \\
\hline
\end{tabular}

*BECKMAN INSTRUMENTS INC/BIOANALYTICAL SYSTEMS GROUP

*BRINKMANN INSTRUMENTS INC

*E L E INTERNATIONAL INC/SOILTEST PRODUCTS DIV

*MARK IV INDUSTRIES INC/L F E INSTRUMENTS

*MICRO ESSENTIAL LABORATORY INC

*WATER RESOURCES INTERNATIONAL INC

*WORLD PRECISION INSTRUMENTS INC

- *YELLOW SPRINGS INSTRUMENT CO INC 
WHC-SD-TD-RPT-011

Revision 0

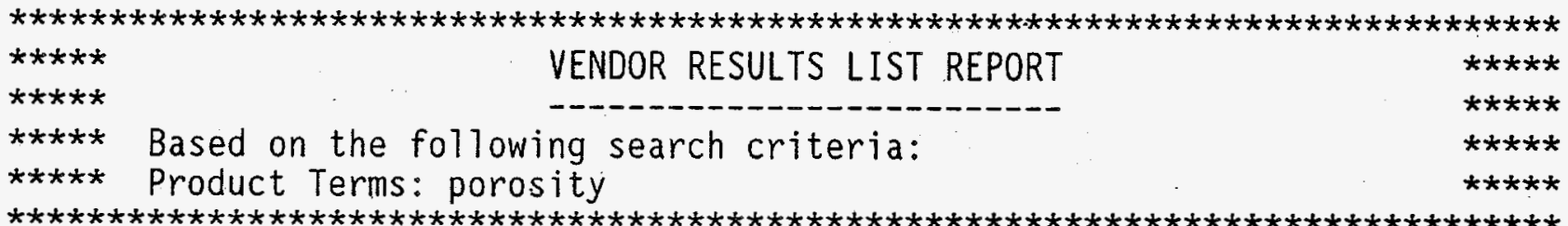

*MICROMERITICS INSTRUMENT CORP

*MOTT METALLURGICAL CORP

*OSMONICS INC

*RADIAC ABRASIVES

*S S I TECHNOLOGIES INC

*SCHLUMBERGER LTD/SCHLUMBERGER WELL SERVICES

*TELEDYNE INC/TELEDYNE GURLEY

*TESTING MACHINES INC

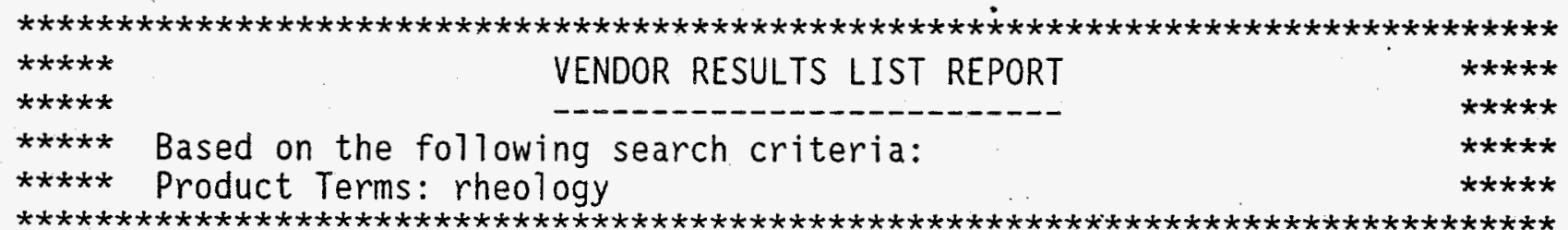

*BRABENDER ( $C^{\circ} W$ ) INSTRUMENTS INC

*METTLER-TOLEDO INC

*MORTON INTERNATIONAL INC/SPECIALTY CHEMICALS GROUP

*RHEOMETRICS INC

\begin{tabular}{|c|c|c|}
\hline 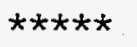 & VENDOR RESULTS LIST REPORT & 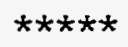 \\
\hline$* * * * *$ & $---------------n---------$ & $* * * * *$ \\
\hline $\begin{array}{l}* * * * * \\
\star * * * *\end{array}$ & Based on the following search criteria: & $\begin{array}{l}* * * * * \\
\star * * * *\end{array}$ \\
\hline
\end{tabular}

*ALLIEDSIGNAL INC/ALLIEDSIGNAL AEROSPACE CO/GUIDANCE SYSTEMS DIV/BENDIX CHESHIRE OPNS

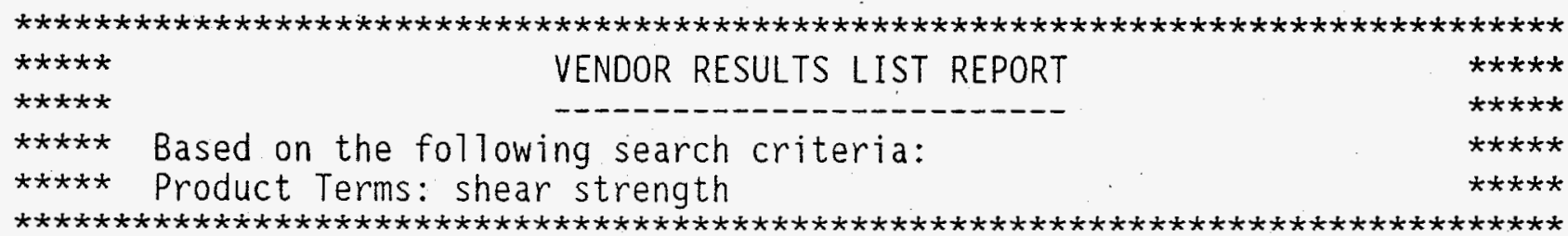

*E L E INTERNATIONAL INC/SOILTEST PRODUCTS DIV

Appendix $\mathrm{F}-3$ 
WHC-SD-TD-RPT-011 .

Revision 0

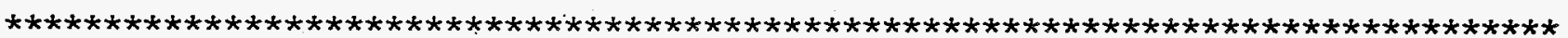

$* * * * *$

- VENDOR RESULTS LIST REPORT

$* * * * *$

$\star \star * * *$

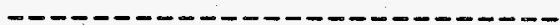

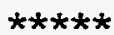

$* * * * *$ Based on the following search criteria: $* * * * *$

$\star \star \star * * *$ Product Terms: shear wave

$\star * * * *$

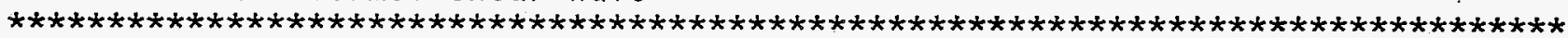

*BISON INSTRUMENTS INC
\end{abstract}

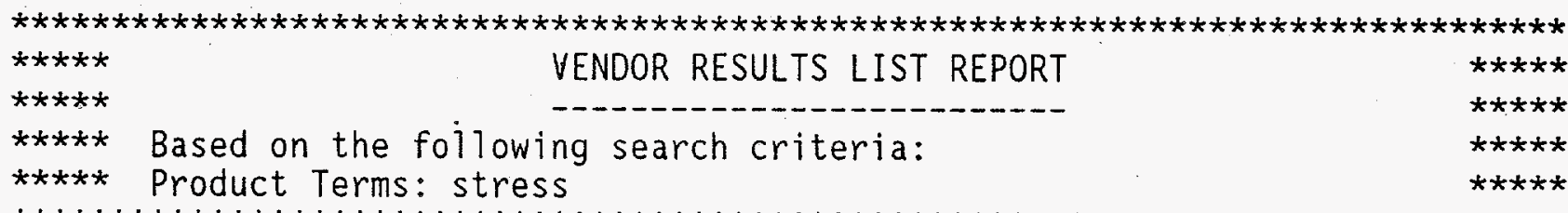

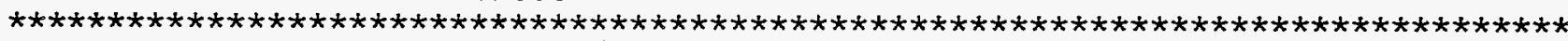

*APPLIED TEST SYSTEMS INC

*GENRAD INC/STRUCTURAL TEST PRODUCTS

*OMEGA ENGINEERING INC

*PUBLICKER INDUSTRIES INC/ASSOCIATED TESTING LABORATORIES

*RESEARCH INC

*SOLTEC CORP

*STRESS RELIEF ENGINEERING CO

*TELEDYNE INC/TELEDYNE BROWN ENGINEERING/TELEDYNE ENGINEERING SERVICES DIV

*VISHAY INTERTECHNOLOGY INC/MEASUREMENTS GROUP INC

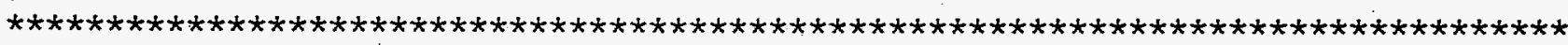

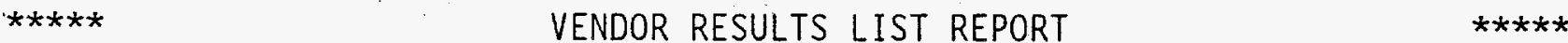

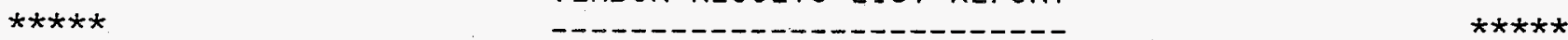

$* * * * *$ Based on the following search criteria: $* * * * *$

$\star * * * *$ Product Terms: strength . $* * * * *$

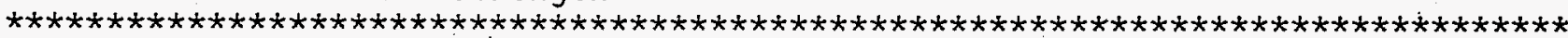

*CHATILLON (JOHN) \& SONS INC/FORCE MEASUREMENT DIV.

*E L E INTERNATIONAL INC/SOILTEST PRODUCTS DIV

*G S E INC/MEASUREMENT \& CONTROL

*MICRO INSTRUMENT CO

*OCCIDENTAL PETROLEUM CORP/OCCIDENTAL CHEMICAL CORP/DUREZ DIV

*OLSEN (TINIUS) TESTING MACHINE CO INC

*ROHDE \& SCHWARZ INC/MEASUREMENT EQUIPMENT

*TESTING MACHINES INC

*WEST COAST RESEARCH CORP

*WESTERN ATLAS INTERNATIONAL INC/CORE LABORATORIES INSTRUMENTS

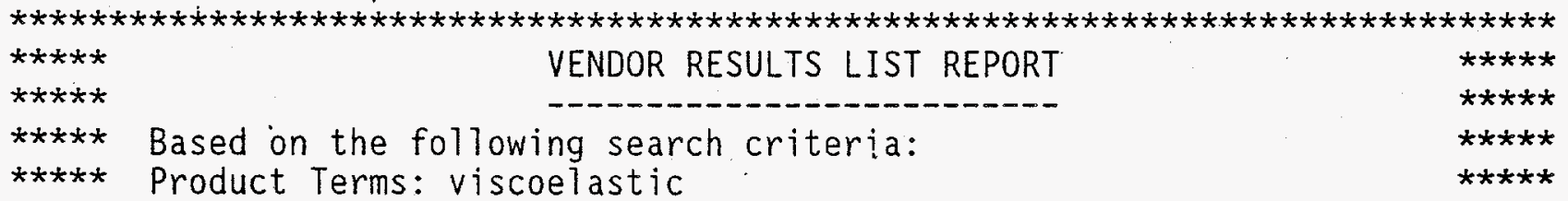


WHC-SD-TD-RPT-011

Revision 0

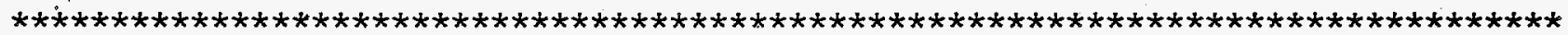

*NAMETRE CO

Appendix F-5 


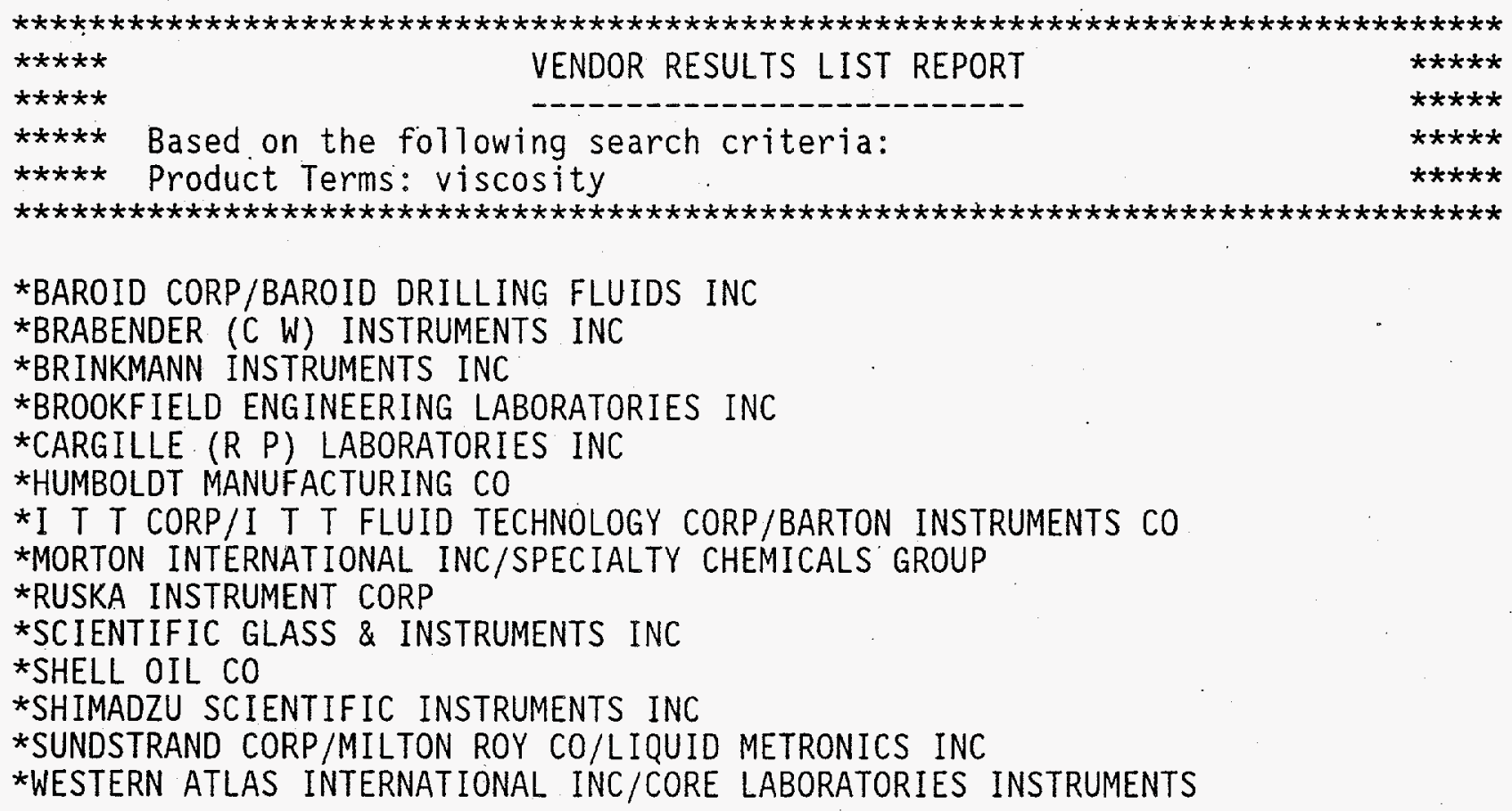


WHC-SD-TD-RPT-011

Revision 0

\section{APPENDIX G. \\ SEARCH RESULTS FOR DEPTH PENETRATION DEVICE \\ ON CD-ROM MASTER VENDOR CATALOG}

Reproduced from Information Handling Services.

Vendor Master Directory. May-Jun 1994 Issue.

Thu Nov 04 01:03:20 1993

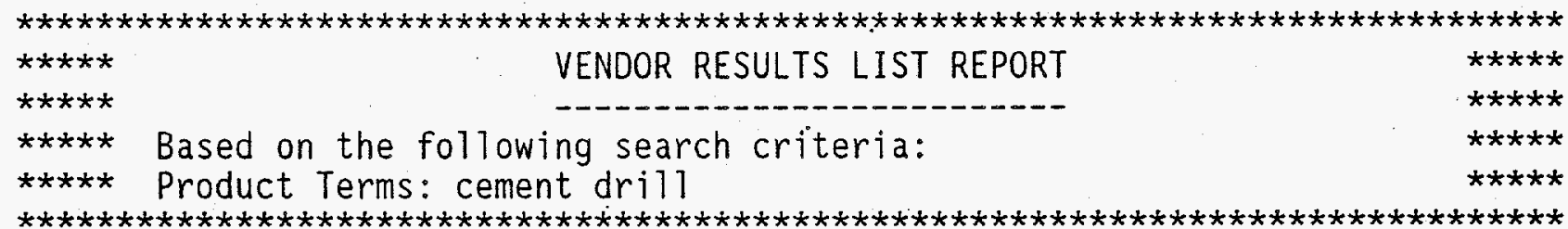

*E L E INTERNATIONAL INC/SOILTEST PRODUCTS DIV

*HILTI INC

*HUMBOLDT MANUFACTURING CO

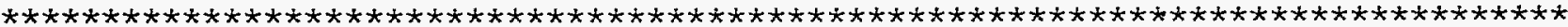

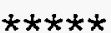
VENDOR RESULTS LIST REPORT

$\star * * * *$

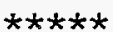

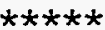

$* * * * *$ Based on the following search criteria:

$* * * * *$ Product Terms: concrete drill

$* * * * *$

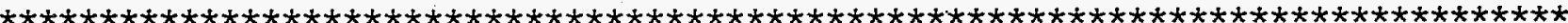

*E L E INTERNATIONAL INC/SOILTEST PRODUCTS DIV

*HILTI INC

*HUMBOLDT MANUFACTURING CO

*JAMES INSTRUMENTS INC

*NORTON CO/NORTON CONSTRUCTION PRODUCTS

*REIMANN \& GEORGER INC

*S-B POWER TOOL CO/BOSCH POWER TOOL DIV

*SLOPE INDICATOR CO

*SOKKIA CORP 
WHC-SD-TD-RPT-011

Revision 0

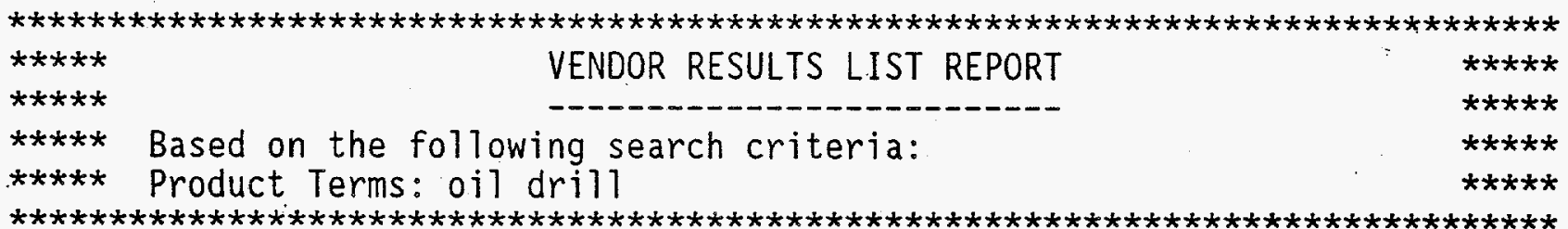

*A S L INC

*AMERICAN DRILL BUSHING CO

*AMERICAN LUBRICANTS CO

*ATLAS COPCO CONSTRUCTION \& MINING NORTH AMERICA

*BAKER HUGHES INC.BAKER HUGHES DRILLING EQUIPMENT/EASTMAN CHRISTENSEN CO

*CENTRAL STEEL \& WIRE CO

*CITGO PETROLEUM CORP/LUBRICANTS \& SPECIALTY PRODUCTS DIV

*DERRICK MANUFACTURING CORP/DERRICK EQUIPMENT CO

*DU PONT CO/CONOCO INC

*JERGENS INC

*KERR-MC GEE CORP/KERR-MC GEE REFINING CORP/CATO OIL \& GREASE CO

*KURTZ (JAMES H) STEEL CO

* LAPHAM-HICKEY STEEL CORP

*MOBIL OIL CORP

*PRECISION-MARSHALL STEEL CO

*RUSKA INSTRUMENT CORP

*TEXAS REFINERY CORP

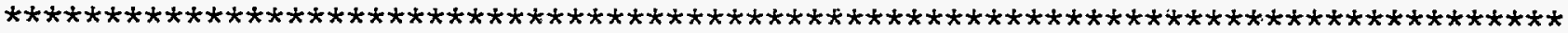

$+\operatorname{tat} x$

$\star * * * *$ Based on the following search criteria:

$\star \star * * *$ Product Terms: soil dri11

*BEN MEADOWS CO

*CLEMENTS ASSOCIATES INC

*GENERAL MOTORS CORP/A-C DELCO DIV

*SLOPE INDICATOR CO 
WHC-SD-TD-RPT-011

Revision 0

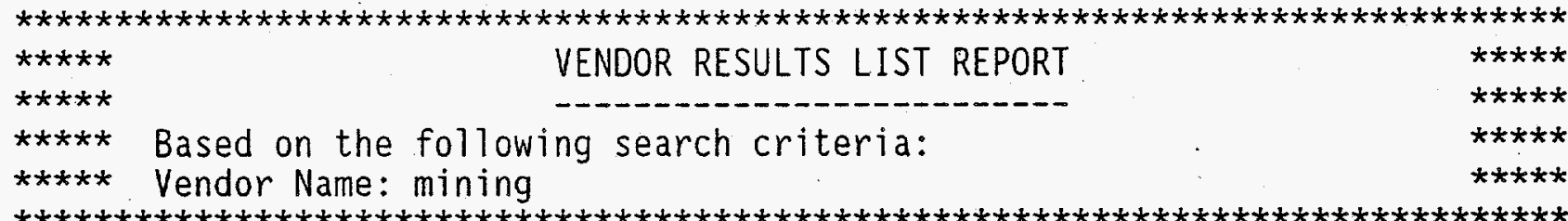

*ATLAS COPCO CONSTRUCTION \& MINING NORTH AMERICA

*BRUSH WELLMAN INC/BERYLLIUM/MINING DIV

*JEFFREY MINING MACHINERY DIV, DRESSER INDUSTRIES INC - NOW - DRESSER

INDUSTRIES INC/JEFFREY DIV

*BAKER HUGHES INC/ BAKER HUGHES MINING EQUIPMENT/ E I M C O MINING EQPT, E I M

C O JARVIS CLARK - NOW - EIMCO JARVIS CLARK

*ENVIROTECH CORP, EIMCO MINING MACHINERY GROUP - NOW - EIMCO JARVIS CLARK

*EAGLE-PICHER INDUSTRIES INC/ELMAC CORP, MINING MACHINE PARTS - Now -

FAIRCHILD

INTERNATIONAL

*ELMAC CORP, MINING MACHINE PARTS DIV - NOW - FAIRCHILD INTERNATIONAL *FOSROC INC/CELTITE MINING \& TUNNELING DIV

*WESTINGHOUSE AIR BRAKE CO, MINING EQUIPMENT DIV - Now - GOODMAN EQUIPMENT CORP

*HARNISCHFEGER INDUSTRIES INC/HARNISCHFEGER CORP/MINING EQUIPMENT DIV

*MINEREC MINING CHEMICALS

*CALLAHAN MINING CORP / PATHWAY BELLOWS INC - NOW. - PATHWAY BELLOWS INC

*COOPER INDUSTRIES INC/ GARDNER-DENVER MINING \& CONSTRUCTION - NOW - REEDRILL INC

*GARDNER-DENVER MINING \& CONSTRUCTION - NOW - REEDRILL INC

*SHATTUCK DENN MINING CORP, RICHMOND SCREW ANCHOR DIV - NOW - RICHMOND SCREW ANCHOR CO

*HUGHES MINING TOOLS - NOW - SANDVIK ROCK TOOLS INC/MINERAL TOOLS DIV

*MINING TOOLS INC - NOW - SANDVIK ROCK TOOLS INC/MINERAL TOOLS DIV

*S I I MINING TOOLS - NOW - SANDVIK ROCK TOOLS INC/MINERAL TOOLS DIV

*SII MINING TOOLS - NOW - SANDVIK ROCK TOOLS INC/MINERAL TOOLS DIV

*SMITH INTERNATIONAL INC/ MINING TOOLS DIV - NOW - SANDVIK ROCK TOOLS

INC/MINERAL TOOLS DIV

*BAKER HUGHES INC/BAKER HUGHES MINING EQUIPMENT/ E I M C O MINING EQPT, E I M C

0 COAL MACHINERY - NOW - TAMPELLA POWER CORP/TAMROCK CO, EIMCO COAL MACHINERY INC

*E I M C O COAL MACHINERY INC/ E I M C O MINING EQUIPMENT/ E I M C O COAL

MACHINERY DIV - NOW - TAMPELLA POWER CORP/TAMROCK CO, EIMCO COAL MACHINERY

INC

*EIMCO COAL MACHINERY INC/E I M C O MINING EQUIPMENT/E I M C O COAL MACHINERY

DIV - NOW - TAMPELLA POWER CORP/TAMROCK CO, EIMCO COAL MACHINERY INC

*F M C CORP/ MINING EQUIPMENT DIV - NOW - TAMPELLA POWER CORP/TAMROCK CO, EIMCO

COAL MACHINERY INC

*FMC CORP/MINING EQUIPMENT DIV - NOW - TAMPELLA POWER CORP/TAMROCK CO, EIMCO

COAL MACHINERY INC 
WHC-SD-TD-RPT-011

Revision 0

*W V A MINING EQUIPMENT CO - NOW - TAMPELLA POWER CORP/TAMROCK CO, EIMCO COAL MACHINERY INC

*MINNESOTA MINING \& MANUFACTURING CO - NOW - THREE M CO (3M)/AEROSPACE MATERIALS DEPARTMENT

*MINNESOTA MINING \& MANUFACTURING CO - NOW - THREE M CO (3M)/CARBONLESS PRODUCTS DEPT

*MINNESOTA MINING \& MANUFACTURING CO - NOW - THREE M CO (3M)/CERAMIC MATERIALS DEPT

*MINNESOTA MINING \& MANUFACTURING CO - NOW - THREE M CO (3M)/COMMERCIAL GRAPHICS DIV

*MINNESOTA MINING \& MANUFACTURING CO - NOW - THREE M CO (3M)/CONSTRUCTION MARKETS DIV

*MINNESOTA MINING \& MANUFACTURING CO - NOW - THREE M CO (3M)/ELECTRICAL PRODUCTS DIV

*MINNESOTA MINING \& MANUFACTURING CO - NOW - THREE M CO (3M)/ELECTRICAL SPECIALTIES DIV

*MINNESOTA MINING \& MANUFACTURING CO - NOW - THREE M CO (3M)/ELECTRONIC PRODUCTS DIV

*MINNESOTA MINING \& MANUFACTURING CO - NOW - THREE M CO (3M)/ELECTRONIC PRODUCTS DIV/ELECTRONIC SPECIALTY MARKETS

*MINNESOTA MINING \& MANUFACTURING CO - NOW - THREE M CO (3M)/ELECTRONIC PRODUCTS DIV/TEXTOOL PRODUCTS DEPT

*MINNESOTA MINING \& MANUFACTURING CO - NOW - THREE M CO (3M)/HARDGOODS AND PACKAGING

*MINNESOTA MINING \& MANUFACTURING CO - NOW - THREE M CO (3M)/HEALTH INFORMATION SYSTEMS

*MINNESOTA MINING \& MANUFACTURING CO - NOW - THREE M CO (3M)/INDUSTRIAL \& CONSUMER SECTOR

*MINNESOTA MINING \& MANUFACTURING CO - NOW - THREE M CO (3M)/INDUSTRIAL MINERAL PRODUCTS DIV

*MINNESOTA MINING \& MANUFACTURING CO - NOW - THREE M CO (3M)/INDUSTRIAL TAPE \& SPECIALTIES DIV

*MINNESOTA MINING \& MANUFACTURING CO - NOW - THREE M CO (3M)/MASKING \& PACKAGING S SYSTEMS DIV

*MINNESOTA MINING \& MANUFACTURING CO - NOW - THREE M CO (3M)/OCCUPATIONAL HEALTH \& ENVIRONMENTAL SAFETY DIV

*MINNESOTA MINING \& MANUFACTURING CO - NOW - THREE M CO (3M)/OFFICE DOCUMENT SYSTEMS DIV

*MINNESOTA MINING \& MANUFACTURING CO - NOW - THREE M CO (3M)/OPTICAL SYSTEMS

*MINNESOTA MINING \& MANUFACTURING CO - NOW - THREE M CO (3M)/PHOTOCOLOR SYSTEMS DIV

*MINNESOTA MINING \& MANUFACTURING CO - NOW - THREE M CO (3M), PRINTING \& PUBLISHING SYSTEMS DIV

*MINNESOTA MINING \& MANUFACTURING CO - NOW - THREE M CO (3M)/PRODESIGN INC

*3M THREE M CO/MINNESOTA MINING \& MANUFACTURING. SAFETY \& SECURITY SYSTEMS DIV - NOW - THREE M CO (3M)/SAFETY \& SECURITY SYSTEMS DIV

*MINNESOTA MINING \& MANUFACTURING CO - NOW - THREE M CO (3M)/SAFETY \& SECURITY SYSTEMS DIV

*THREE M CO (3M)/ MINNESOTA MINING \& MANUFACTURING SAFETY \& SECURITY SYSTEMS DIV - NOW - THREE M CO (3M)/SAFETY \& SECURITY SYSTEMS DIV

*MINNESOTA MINING \& MANUFACTURING CO - NOW - THREE M CO (3M)/SARNS 3M HEALTH 
WHC-SD-TD-RPT-011

Revision 0

\section{CARE}

*MINNESOTA MINING \& MANUFACTURING CO - NOW - THREE M CO (3M)/SOUND PRODUCTS

*MINNESOTA MINING \& MANUFACTURING CO - NOW - THREE M CO (3M)/SPECIALTY CHEMICALS DIV

*MINNESOTA MINING \& MANUFACTURING CO - NOW - THREE M CO (3M)/TEXTOOL TEST \& INTERCONNECT PRODUCTS DEPT

*MINNESOTA MINING \& MANUFACTURING CO - NOW - THREE M CO (3M)/THREE M ABRASIVE SYSTEMS DIV

*MINNESOTA MINING \& MANUFACTURING CO - NOW - THREE M CO (3M)/THREE M HEALTH CARE

*MINNESOTA MINING \& MANUFACTURING CO - NOW - THREE M CO (3M)/THREE M HOME \& COMMERCIAL CARE DIV

*MINNESOTA MINING \& MANUFACTURING CO - NOW - THREE M CO (3M)/THREE M PRERECORDED OPTICAL MEDIA

*MINNESOTA MINING \& MANUFACTURING CO - NOW - THREE M CO (3M)/THREE M TELECOM SYSTEMS DIV

*MINNESOTA MINING \& MANUFACTURING CO - NOW - THREE M CO (3M)/TRAFFIC CONTROL MATERIALS DIV

*MINNESOTA MINING \& MANUFACTURING CO - NOW - THREE M CO (3M)/VISUAL SYSTEMS DIV 
WHC-SD-TD-RPT-011

Revision 0

\section{APPENDIX H. \\ SELECTED VENDORS FROM CD-ROM MASTER VENDOR CATALOG SEARCH FOR DEPTH PENETRATION DEVICES}

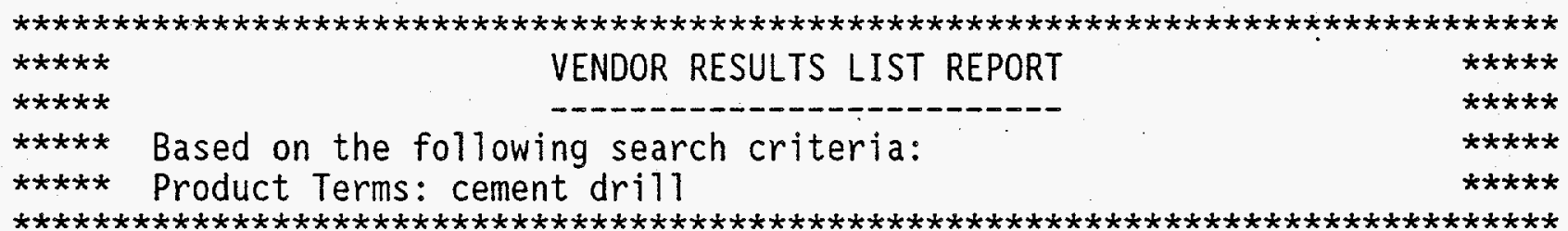

*E L E INTERNATIONAL INC/SOILTEST PRODUCTS DIV

*HILTI INC

*HUMBOLDT MANUFACTURING CO

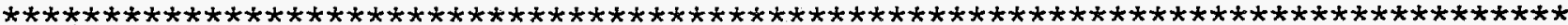

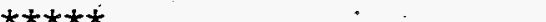

$\star * * * *+$

VENDOR RESULTS LIST REPORT

$\star \star \star * \star *$

.

$\star \star \star * *$ Based on the following search criteria:

***** Product Terms: concrete drj]1

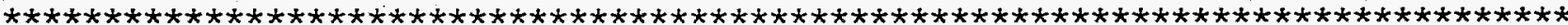

*E L E INTERNATIONAL INC/SOILTEST PRODUCTS DIV

*HILTI INC

*HUMBOLDT MANUFACTURING CO

*JAMES INSTRUMENTS INC

*SLOPE INDICATOR CO

\begin{tabular}{|c|c|c|c|}
\hline 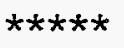 & & VENDOR RESULTS LIST REPORT & 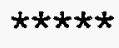 \\
\hline 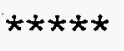 & & -------------------------- & $\star \star \star * *$ \\
\hline 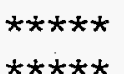 & Based on the follow & ing search criteria: & $\begin{array}{l}\star \star \star \star \star \star ~ \\
\star \star \star \star \star *\end{array}$ \\
\hline
\end{tabular}

*ATLAS COPCO CONSTRUCTION \& MINING NORTH AMERICA

*BAKER HUGHES INC/BAKER HUGHES DRILLING EQUIPMENT/EASTMAN CHRISTENSEN CO 
WHC-SD-TD-RPT-011

Revision 0

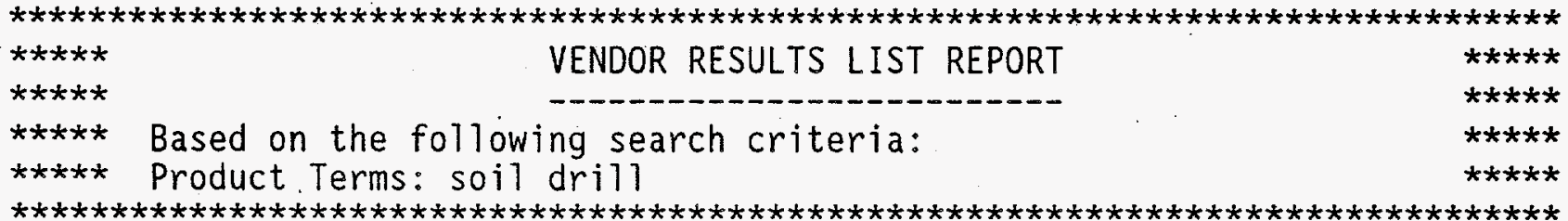

*CLEMENTS ASSOCIATES INC

*SLOPE INOICATOR CO

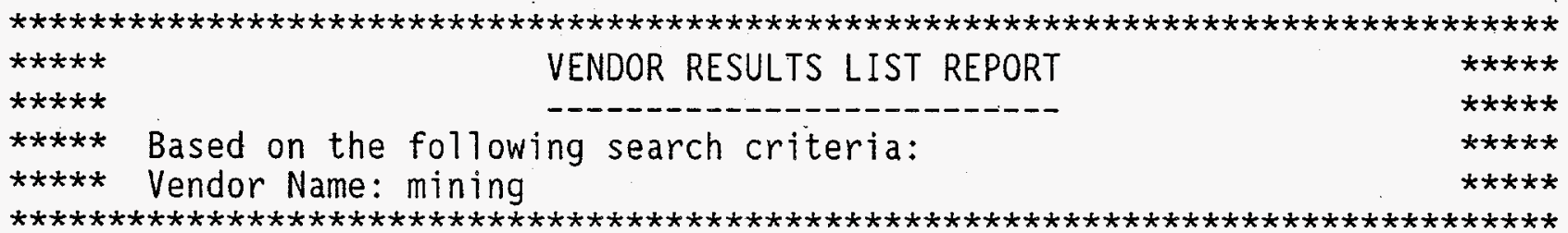

*JEFFREY MINING MACHINERY DIV, DRESSER INDUSTRIES INC - NOW - DRESSER

INDUSTRIES INC/JEFFREY DIV

*BAKER HUGHES INC/ BAKER HUGHES MINING EQUIPMENT/ E I M C O MINING EQPT, E I M C 0 JARVIS CLARK - NOW - EIMCO JARVIS CLARK

*FOSROC INC/CELTITE MINING \& TUNNELING DIV

*HUGHES MINING TOOLS - NOW - SANDVIK ROCK TOOLS INC/MINERAL TOOLS DIV 
WHC-SD-TD-RPT-011

Revision 0

\section{APPENDIX I. \\ ANNOUNCEMENTS IN THE COMMERCE BUSINESS DAILY (CBD) FOR TANK WASTE PHYSICAL PARAMETER AND DEPTH PROFILING SENSORS}

\section{Potential Sources Sought}

SENSORS FOR ROBOTIC ARM. POC Keith Hoeft, 509/376-3953, Senior Procurement Specialist, Richland, WA. Organizations having capabilities and experience to furnish various sensors that can be connected at the end of a robot arm or be independent of the robot are invited to submit information demonstrating their product/concept(s), etc. for the sensor(s) described in this synopsis. This is not a Request for Proposal, but a request for information. The sensor is inserted from the top of one million gallon capacity waste tanks, to perform an in situ test of physical characteristics of the radioactive waste (up to $1000 \mathrm{R} / \mathrm{hr}$ ). The tank waste form ranges from liquid to solid. The sensors must be able to measure one or more of the physical properties of waste. Tank waste physical properties of interest are: shear stress and shear strength, shear rate, shear wave velocity, yield stress, viscosity, viscoelastic, abrasiveness, corrosiveness, permeability, density, temperature, $\mathrm{pH}$, compressive strength, porosity, rheology. The sensor must conform to the requirements and constraints of any apparatus connected at the end of the robot arm or applications device. For instance, as a minimum requirement for the robot arm sensor, the weight. of the device must be less than 50 pounds and it must be smaller than a cylinder envelope with outer diameter of 10.5 inches and length of 30 inches. For maintenance, the sensor must be able to function continuously for at least 10 hours without failure. A single part replacement is acceptable for every 1000 hours of operation. Internal tank environment is +70 to $150 \mathrm{~F}$, humidity of $10 \mathrm{w}$ to $100 \%$, T-0J, abrasive dust, \pm 10 inches of pressure, concentrated nitric acid fumes to $\mathrm{pH}$ of 14 and radiation of up to $1000 \mathrm{rad} / \mathrm{hr}$. External tank environment is -20 to $115 \mathrm{~F}, 4 \%$ to $100 \%$ humidity, wind speeds of 0 to $129 \mathrm{miles} / \mathrm{hr}$, rainfall. up to 2 inches $/ \mathrm{hr}$, snowfall up to 2 feet and severe dust storms. Must be able to withstand a decontamination spray of $250 \mathrm{lb} / \mathrm{in}^{2}$. Decontamination solutions may include water, $\mathrm{CO}_{2}, 3$ to 6 molar nitric acid, 3 to 6 molar oxalic acid, Turco cleaning compound 4502 at $250 \mathrm{~F}$. In responding to this advertisement, Seller shall describe any experience or capability to furnish sensors as described above, and is requested to furnish Company product brochures, design concepts, product categories, etc. Westinghouse Hanford Company will not award an offer on the basis of the synopsis nor compensate any respondent for responding to this announcement.

SURFACE PENETRATION DEVICE POC Keith Hoeft, 509/376-3953, Senior Procurement Specialist, Richland, WA. Organizations having capabilities and experience to furnish a surface penetration device that can penetrate waste surface to allow deployment of sensor at various depths are invited to submit information demonstrating their product/concepts, etc. for the equipment described in this synopsis. This is not a Request for Proposal, but a request for information. The penetration device can be connected at the end of a robot arm or a suitable deployment mechanism, which will be inserted from the 
top of one million gallon capacity radioactive waste (up to $1000 \mathrm{R} / \mathrm{hr}$ ) storage tanks. The device should be able to penetrate waste surface with numerous hole sizes; at minimum, the drilled hole must be at least 1 inch in diameter and 30 inches deep. The tank waste can be in any of the three forms: soft waste (sludge), hard sludge (peanut butter consistency) and salt cake (solid) which can be as hard as dried concrete but also water soluble. The penetration device must conform to the requirements and constrains of any apparatus connected at the end of the robot arm or applications device. For instance, as a minimum requirement for the robot arm apparatus, the weight of the device must be less than 50 pounds and it must be smaller than a cylinder envelope with outer diameter of 10.5 inches and length of 30 inches: For maintenance, the penetration device must be able to function continuously for at least 10 hours without failure. In responding to this advertisement, Seller shall describe any experience or capability to furnish a surface penetration device as described above, and is requested to furnish Company product brochures, design concepts, product categories, etc. Westinghouse Hanford Company will not award an offer on the basis of this synopsis nor compensate any respondent for responding to this announcement. 
WHC-SD-TD-RPT-011

Revision 0

RESPONDED VENDORS LISTING FROM THE ANNOUNCEMENTS IN THE COMMERCE BUSINESS DAILY AND THOSE SELECTED IN APPENDIX $F$ AND $H$

\author{
Accutech \\ 6032 197th Avenue East \\ Sumner, QA 98390-8876 \\ Bio-Rad Laboratories, Inc. \\ 2000 Alfred Nobel Drive \\ Hercules, CA 94547
}

C. W. Brabender Instruments, Inc:

50E. Wesley St.

P.0. Box 2127

So. Hackensack, NJ 07606

Foster-Miller, Inc.

Techonology Developers

350 Second Ave.

Waltham, MA 02154-1196

ITT Fluid Technology Corporation .

900 South Turnbu71. Canyon Road

P.0. Box 1882

City of Industry, CA.91749-1882

Nametre Company

101 Forrest Street

Metuchen, NJ 08840

Omega Engineering, Inc.

One Omega Drive

P.0. Box 4047

Stanford, CT 06907-0047

Phil ip Timmons, Inc.

P.0. Box 210066

Dallas, TX 75211-0066

Quest Integrated, Inc.

21414 68th Ave. South

Kent, WA 98032

Robotech Industries LTD.

4040 Brandon Street S.E.

Calgary, ATberta, CANADA T2G 4 A8 


\section{WHC-SD-TD-RPT-011 \\ Revision 0}

Shimadzu Scientific Instruments, Inc.

7102 Riverwood Drive

Columbia, Maryl and 21046

Visidyne, Inc.

10 Corporate Place

South Bedford Street

Burlington, Massachusetts 01803

West Coast Research Corp.

1527.26th Street

Santa Monica, CA 90404 
WHC-SD-TD-RPT-011

Revision 0

APPENDIX K.

SEARCH RESULTS FROM WHC ENGINEERING RELEASE SYSTEM-DATABASE (ERS-DB)

FOR TANK WASTE PHYSICAL PARAMETERS

Keyword: VISCOSITY

$\star * * *$

* SD-WM-TI-012

* SD-WM-TI-222

* SD-WM-TI-247

* SD-WM-WP-242

* SD-WM-CSRS-017

* SD-WM-ATP-079

* SD-WM-DA-151

PUREX DECLADDING WASTE-VISCOSI

TY \& FLOWRATE VERSUS PRESSURE DROP CALCULATIONS

VISCOSITY STUDY - PREDICTION 0

F ELECTROLYTIC SOLUTIONS \& SLU RRIES

VALIDATION OF VISCOSITY CORREL * ATION FOR SLURRIES

TANK SY-101 IN SITU VISCOMETER

INSTRUMENT ENGINEERING WORK $P$

LAN

SOFTWARE REQUIREMENTS SPECIFIC ATION FOR TANK 101-SY VISCOMET - ER

SOFTWARE ACCEPTANCE TEST PROCE DURE FOR TANK 101-SY VISCOMETE $\mathrm{R}$

VISCOMETER ELECTRICAL CODES AN D COMPLIANCE

Keyword: CORROSION $* * *$

* HWS-10249

* HWS -05643

* HWS-08846

* HS-BP-0046

* SD-CP-ES-058

* SD-CP-TC -008

* SD-WM-PAP-025

* SD-WM-TI-150

* SD-WM-TI-16I

* SD-WM-TI-166

PROC SPEC FOR ULTRASONIC CORRO SION INSPCTN SYSTM

SPEC FOR VERTICAL TURBINE PUMP $S$ FOR NON-CORROSIVE SVC SPEC FOR SUBMERSIBLE TYPE PUMP $S$ FOR NON-CORROSIVE SERVICE SUBMERSIBLE VERTICAL TURBINE $P$ UMP FOR NON-CORROSIVE SERVICE TECHNOLOGY SURVEY OF SMALL COR ROSION RESISTANT PUMPS FOR INHOOD SERVICE

PFP CORROSION EVALUATION PLAN HANFORD WASTE TANK CORROSION S TUDY TECHNOLOGY PROGRAM PLAN TECHNICAL BASIS FOR WASTE TANK CORROSION SPECIFICATIONS

REFERENCES FOR TECHNICAL BASIS FOR WASTE TANK CORROSION SPEC IFICATIONS

HIGH TEMPERATURE CORROSION TES TS ON DOUBLE-SHELL SLURRY \& FU TURE PUREX MIXTURES-TWELVE MON TH EVALUATION 
* SD-WM-ER-034

* SD-WM-ER-035

* SD-WM-TC-008

* SD-WM-ER-041

* SD-WM-ES-135

* SD-CP-DA-042

* SD-WM-TI-467

* SD-WM-EV-054

* SD-WM-TP-111

* SD-WM-ANAL-009

* SD-CP-WP-017

* SD-CP-TP-072

* SD-HWV-TI-030

* SD-W236A-TP-001

* SD-CP-WP-016

* SD-CP-WP-018

* SD-NR-TP-020

* SD-WM-ER-209

* SD-W236A-TRP-001
CORROSION STUDY ON THE STANDAR D BURIAL BOX CORROSION STUDY ON GENERAL BUR IAL BOX

CORROSION STUDY OF SHIELDING L EAD IN HANFORD SOIL (CONTINUED IN FY-89)

CORROSION STUDY OF SOLID LEAD

IN HANFORD SOILS FY-88

CORROSION STUDY OF THE 244-AR

VAULT TANKS 001-002-003 AND 00 4

DESIGN ANALYSIS FOR REPAIR AND CORROSION PROOFING OF C-CELL PREDICTION EQUATIONS FOR CORRO SION RATES OF A-537 AND A-516 STEELS IN DOUBLE SHELL SLURRY, FUTURE PUREX AND HANFORD FACI ILTIES WASTE

DOUBLE-SHELL WASTE TANK IN-TAN $K$ CORROSION MONITORING PROGRAM TEST PLAN FOR CORROSION EVALUA TION OF TRUEX PLANT MATERIALS 244-BX DOUBLE-CONTAINED RECEIV ER TANK (DCRT) CORROSION STUDY PFP WASTE TANK SYSTEM DESIGN E VALUATION VISUAL INSPECTION AN D CORROSION ASSESSMENT WORK PL AN

FILTER MEDIA CORROSION TEST PL AN

CORROSION EVALUATION FOR ACCEP TANCE OF HANFORD WASTE VITRIF I CATION PLANT ALLOYS

MULTI-FUNCTION WASTE TANK FACI LITY CORROSION TEST PLAN CORROSION ASSESSMENT PLAN FOR THE PUREX DANGEROUS WASTE TANK $S$

CORROSION ASSESSMENT REPORT FO $R$ THE PUREX DANGEROUS WASTE TA NK SYSTEMS

100-K BASIN CORROSION STUDY

HANFORD SITE SINGLE-SHELL TANK LEVEL HISTORIES FOR CORROSION ANALYSIS

MULTI-FUNCTION WASTE TANK FACI LITY CORROSION TEST REPORT, PH ASE 1

Keyword: DENSITY 
WHC-SD-TD-RPT-011

Reyision 0

* SD-WM-TI-268

* SD-HWV-TI-020

* SD-WM-0TP-133

* SD-WM-SDD-005

* SD-WM-OTR-133

* SD-WM-DA-113

* SD-WM-TI-534

* SD-WM-WP-201

PRACTICAL CONSIDERATIONS OF HI GH-DENSITY COMPACTION SYSTEMS FOR USE IN THE WASTE RECEIVING \& PROCESSING (WRAP) FACILITY

SOIL DENSITY AND MASS ATTENUAT ION COEFFICIENTS FOR USE IN SH IELDING CALCULATIONS AT THE HA NFORD WASTE VITRIFICATION PLAN $T$

VELOCITY DENSITY TEMPERATURE T REE - VDTT- OPERATIONAL TEST PR OCEDURE

VELOCITY DENSITY TEMPERATURE T REE VDTT SYSTEM DESIGN DESCRIP TION

VELOCITY DENSITY TEMPERATURE T REE VDTT OPERATIONAL TEST REPO RT

STRUETURAL ANALYSIS OF TANK 24 1-SY-101 VELOCITY-DENSITY-TEMP ERATURE TREE

VELOCITY DENSITY TEMPERATURE T REE VDTT INSTRUMENT TECHNICAL INFORMATION WORK PLAN TO VACUUM DRY AND CA LIBRATE SY-101 VELOCITY DENSIT $Y$ TEMPERATURE TREES VDTTS

Keyword: COMPRESSIVE STRENGTH $* * *$

* SD-WM-TP-171

MEASUREMENT OF PULSE VELOCITY/ COMPRESSIVE STRENGTH RELATIONS HIP OF GROUTED WASTE

Keyword: TEMPERATURE $\star \star \star *$

* SD-CP-PTP-030

* SD-CP-PTR-009

* SD-CP-TI-099

* SD-RE-0TP-081

* SD-RE-0TR-081

* SD-RE-TI-103

* SD-RE-TI-146

PROCESS TEST PLAN, TEMPERATURE DATA PLUTONIUM OXIDATION PROCESS TEST REPORT - TEMPERAT URE DATA PLUTONIUM OXIDATION REMOTE MECHANICAL C-LINE CALCI NER TEMPERATURE CONTROL TESTS OPERABILITY TEST PROCEDURE FOR SOLVENT TEMPERATURE CONTROL U PGRADE (AR\# P20017)

OPERABILITY TEST REPORT FOR SO LVENT TEMPERATURE CONTROL UPGR ADE (AR\# P20017)

BASES FOR PUREX SOLVENT TANK T EMPERATURE LIMITS

EXPECTED DRILL BIT TEMPERATURE 
WHC-SD-TD-RPT-011

Revision 0

* SD-WM-OCD-002

* SD-WM-0TP-018

* SD-WM-OTR-018

* SD-WM-TI-055

* SD-WM-TI-166

* SD-WM-DA-024

*. SD-WM-DR-003

* SD-714-TI-002

* SD-CP-ATP-007

* SD-CP-ATR-006

* SD-WM-TA-019

* SD-WM-TA-022

* SD-CP-ATP-027

* SD-WM-TI-459

* SD-WM-TC-016

* SD-WM-ER-104

* SD-WM-WP-102

*. SD-WM-RD-013
DURING SAMPLE TAKING IN SINGL E-SHELL TANKS

BASES FOR WESF STRONTIUM FURNA CE FIRING TEMPERATURE

OPERABILITY TEST PROCEDURE FOR TEMPERATURE SCANNING EQUIPMEN T FOR 241-AY \& 241-AZ TANK FAR MS

OPERABILITY TEST REPORT FOR TE MPERATURE SCANNING EQUIPMENT I N 241-AY \& 241-AZ TANK FARM TEMPERATURE INCREASE CAUSED BY SOLIDS SETTLING INTO CORNERS OF BOILING WASTE TANKS HIGH TEMPERATURE CORROSION TES TS ON DOUBLE-SHELL SLURRY \& FU TURE PUREX MIXTURES-TWELVE MON TH EVALUATION

MAXIMUM TEMPERATURE OF CESIUM CANISTER SIPPING SYSTEM AT IRR ADIATION FACILITY

PROCESS WASTE TRANSFER LINES $F$ ROM TANK 241-AZ-101 TO 244-AR

VAULT TEMPERATURE ANALYSIS SCOPING ANALYSIS FOR REDUCING GROUT DISPOSAL SYSTEM TEMPERAT URES

MT 5 TEMPERATURE CONTROL SYSTE $M$ PHASE I

MT-5 TEMPERATURE CONTROL SYSTE $M$ - PHASE I TEST REPORT

SLUDGE IN AGING WASTE TANK AND MAXIMUM OBSERVED TEMPERATURE DOUBLE SHELL TANK OPERATING TE MPERATURE

HC-60, TEMPERATURE CONTROL SYS TEM

EVALUATION OF AMBIENT TEMPERAT URE EFFECTS ON TANK 101-SY GAS MIXING -TASK RECORD-

TEST PROCEDURE FOR DOCUMENTING HIGHEST TEMPERATURE PRODUCED

BY 101-SY DRILLING \& CUTTING O PERATIONS

101-SY DRILLING AND CUTTING OP ERATION TEMPERATURES

WORKPLAN, TEMPORARY GAS MONITO RING SYSTEM, TEMPERATURE AND $R$ ELATIVE HUMIDITY INSTRUMENTATI ON, TANK SY-101

FUNCTIONAL REQUIREMENTS FOR FE RROCYANIDE TANK TEMPERATURE MO 


$$
\begin{gathered}
\text { WHC-SD-TD-RPT-011 } \\
\text { Revision } 0
\end{gathered}
$$

* SD-WM-WP-075

* SD-WM-TI-483

* SD-CP-ATR-027

* SD-WM-TI-486

* SD-WM-ES-183

* SD-WM-ATP-020

* SD-W175-ATR-001

* SD-WM-WP-116

* SD-WM-ATR-020

* SD-WM-WP-130

* SD-WM-TP-122

* SD-WM-CSWD-031

* SD-WM-RPT-038

* SD-WM-SDP-003

* SD-WM-ER-156

* SD-WM-ATR-023

* SD-WM-TRP-084

* SD-WM-TRP-085
NITORING

ENGINEERING WORK PLAN FOR FERR OCYANIDE TANK TEMPERATURE MONI TORING

TEMPERATURE MEASUREMENTT ERROR ANALYSIS

HC-60 TEMPERATURE CONTROL SYST EM

PB1 PUMP PRODUCED TEMPERATURE

RISE IN 242A EVAPORATOR CRYSTA LLIZER

ENGINEERING STUDY OF TEMPERATU RE SENSORS FOR USE IN WASTE TA NK SURVEILLANCE

CONTINUOUS TEMPERATURE MONITOR ING PHASE 1 ACCEPTANCE TEST PR OCEDURE

ACCEPTANCE TEST REPORT \#001 FO $R$ LOW TEMPERATURE SWITCHES

ENGINEERING WORK PLAN FOR FERR OCYANIDE TANK TEMPERATURE MONI TORING PHASE 2 AND PHASE 3 CONTINUOUS TEMPERATURE MONITOR ING PHASE 1 ACCEPTANCE TEST RE PORT

WASTE TANK CORE DRILL TEMPERAT URE ALARM

SURVEILLANCE ANALYSIS COMPUTER SYSTEM (SACS) TEMPERATURE DAT ABASE TEST PLAN

SURVEILLANCE ANALYSIS COMPUTER SYSTEM (SACS) TEMPERATURE DAT A SOFTWARE REQUIREMENTS SPECIF ICATION (SRS)

ROTARY MODE CORE SAMPLING TEMP ERATURE MONITORING

SURVEILLANCE ANALYSIS COMPUTER SYSTEM SACS TEMPERATURE DATAB ASE SOFTWARE PROJECT MANAGEMEN $T$ PLAN SPMP

SURFACE TEMPERATURE DATA RECOR DS AND INTERPRETATION OF INFRA -RED SCANNING OF TANK S-110

TANK MONITOR AND CONTROL SYSTE $M$ TEMPERATURE ACCEPTANCE TEST REPORT

SURVEILLANCE ANALYSIS COMPUTER SYSTEM SACS TEST CASE TCO18 M AXIMUM TEMPERATURE REPORT REQU EST FORM AND OUTPUT

SURVEILLANCE ANALYSIS COMPUTER SYSTEM SACS TEST CASE. TCO19 T 
WHC-SD-TD-RPT-011

Revision 0

* SD-WM-TRP-082

* SD-WM-DP-022

* SD-WM-0TP-133

* SD-WM-SDD-005

* SD-WM-0TR-133

* SD-WM-DA-113

* SD-WM-TRP-087

* SD-WM-TI-534

* SD-WM-TRP-104

* SD-WM-TRP-088

* SD-WM-WP-201

* SD-WM-TRP-116

* SD-WM-CSUD-005

* SD-WM-TI-557

* SD-WM-WP-220

* SD-NR-EII-006
EMPERATURE PROFILE GRAPH

SURVEILLANCE ANALYSIS COMPUTER SYSTEM SACS TEST CASE TC015 S INGLE SHELL TANK MAXIMUM TEMPE RATURE GRAPH

101-SY MIXING PUMP TEMPERATURE AND PRESSURE LOOP CALIBRATION VELOCITY DENSITY TEMPERATURE $T$ REE - VDTT- OPERATIONAL TEST PR OCEDURE

VELOCITY DENSITY TEMPERATURE T REE VDTT SYSTEM DESIGN DESCRIP TION

VELOCITY DENSITY TEMPERATURE T REE VDTT OPERATIONAL TEST REPO RT

STRUCTURAL ANALYSIS OF TANK 24 1-SY-101 VELOCITY-DENSITY-TEMP ERATURE TREE

SURVEILLANCE ANALYSIS COMPUTER SYSTEM SACS TEST CASE TC021 T EMPERATURE PROFILE REPORT REQU EST FORM AND OUTPUT

VELOCITY DENSITY TEMPERATURE T REE VDTT INSTRUMENT TECHNICAL INFORMATION

SURVEILLANCE ANALYSIS COMPUTER SYSTEM SACS TEST CASE TC036 Z OOM FORMS FOR THE BASE TEMPERA TURE SYSTEM

SURVEILLANCE ANALYSIS COMPUTER SYSTEM SACS TEST CASE TCO22 F ARM TEMPERATURE DATA INPUT FOR $M$

WORK PLAN TO VACUUM DRY AND CA LIBRATE SY-10I VELOCITY DENSIT $Y$ TEMPERATURE TREES VDTTS

SURVEILLANCE ANALYSIS COMPUTER SYSTEM SACS TEST CASE TC039, TMACS TEMPERATURE DATE INTERFA CE

SACS TEMPERATURE USER MANUAL PREL IMINARY FLOWSHEET FOR LOW TEMPERATURE HYDROTHERMAL DESTR UCTION OF ORGANICS IN HANFORD TANK WASTES

WORK PLAN FOR TEMPORARY INSTAL. LATION OF TEMPERATURE DATA ACQ UISITION SYSTEM FOR USE DURING TANK 241-AZ-101

KE BASIN TEMPERATURE MONITOR E QUIPMENT INSTALLATION INSTRUCT 
* SD-NR-EII-007

* SD-ER36ं41-OTP-001

* SD-WM-TC-051

* SD-WM-TRP-187
* SD-ER3641-OTP-004

ION

KW BASIN TEMPERATURE MONITOR E QUIPMENT INSTALLATION INSTRUCT ION

OPERABILITY TEST PROCEDURE FOR $244 U$ DCRT GENERAL EQUIPMENT L EAK DETECTOR, HEAT TRACE, TEMP ERATURE, BFP

OPERABILITY TEST PROCEDURE FOR $244 U$ DCRT GENERAL EQUIPMENT, LEAK DETECTOR, HEAT TRACE, TEM PERATURE, BFP

SURVEILLANCE ANALYSIS COMPUTER SYSTEM SACS TEST REPORT TCO53 - PC-SACS TEMPERATURE DATA ENT RY

SURVEILLANCE ANALYSIS COMPUTER SYSTEM SACS TEST REPORT TC 053 PC-SACS TEMPERATURE DATA ENTR $Y$ FORM

Keyword: SHEAR

* ES-BP-0008

* SD-CP-ES-017

* SD-CP-ES-019

* SD-CP-ES-020

* SD-CP-ES-027

* SD-RE-DTP-009

* SD-WM TP-040

* SD-WM-PTD-031

* SD-WM-TP-040

* SD-WM-TC-004

* SD-CP-DA-011

* SD-WM-TRP-032

* SD-CP-TP-064
DESING AND MANUFACTURE OF A BU NDIE SHEAR SYSTEM

A SHEAR/LEACH FACILITY FOR N-F UELS AT PUREX

SHEAR/LEACH PROCESSING OF N-RE ACTOR FUELS, CLADDING HULL WAS TE MANAGEMENT ECONOMIC EVALUATION OF A SHEAR /LEACH HEADEND FOR PROCESSING ZIRCALOY CLAD NPR FUEL

SHEAR/LEACH PROCESS FOR N-REAC REX PLANT

FFTF FUEL BUNDLE SHEAR TEST PL AN

SHEAR VANE TEST PLAN USING SIM ULATED WASTE

PROTOTYPE PLANNING DOCUMENT DO UBLE-SHELL TANK CHARACTERIZATI ON SYSTEM (SHEAR VANE).

SHEAR VANE TEST PLAN USING SIM ULATED WASTE

SHEAR VANE COLD TEST PROCEDURE DESIGN ANALYSIS FOR SHEAR PIN ON ENGAGEMENT ARM OF PUREX CAS $K$ CAR PULLER SHEAR VANE "COLD" TEST REPORT SHEAR-LEACH SHEAR DEVELOPMENT TEST PLAN TOR FUELS PROCESSING AT THE PU 
WHC-SD-TD-RPT-011

Revision 0

* SD-CP-DA-073

DESIGN ANALYSIS FOR SHEAR LEAC

H. DEVELOPMENT TESTING

* SD-EN-TP-039

INTEGRATED TEST PLAN FOR CROSS WELL COMPRESSIONAL AND SHEAR W AVE SEISMIC TOMOGRAPHY FOR SIT E CHARACTERIZATION AT THE VOC ARID SITE

Keyword: PHYSICAL PROPERTY

* SD-WM-TI-513

101-SY WINDOW C CORE SAMPLES E VALUATION OF THE CHEMICAL AND PHYSICAL PROPERTIES

* SD-WM-SD-017 WHC \& PNL ANALYTICAL LABORATOR $Y$ PROCEDURES TO CHARACTERIZE $P$ HYSICAL PROPERTIES OF WASTE

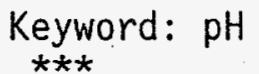

* SD-CP-LB-025

* SD-CP-PPT-007

* SD-CP-TEEM-018

DETERMINATION OF PH VALUES DEMONSTRATION OF AMMONIA FEED PH CONTROL ON A LARGER SCALE PFP LEEDS AND NORTHRUP LIQUID EFFLUENT PH METER

EQUIPMENT INSTALLATION INSTRUC TION FOR PH UPGRADE AT 105KE EQUIPMENT INSTALLATION INSTRUC TION FOR PH MONITORING SYSTEM 


\section{APPENDIX L. \\ SEARCH RESULTS FROM WHC TANK FARM INFO DATABASE (TFI) FOR TANK WASTE CHARACTERIZATION}

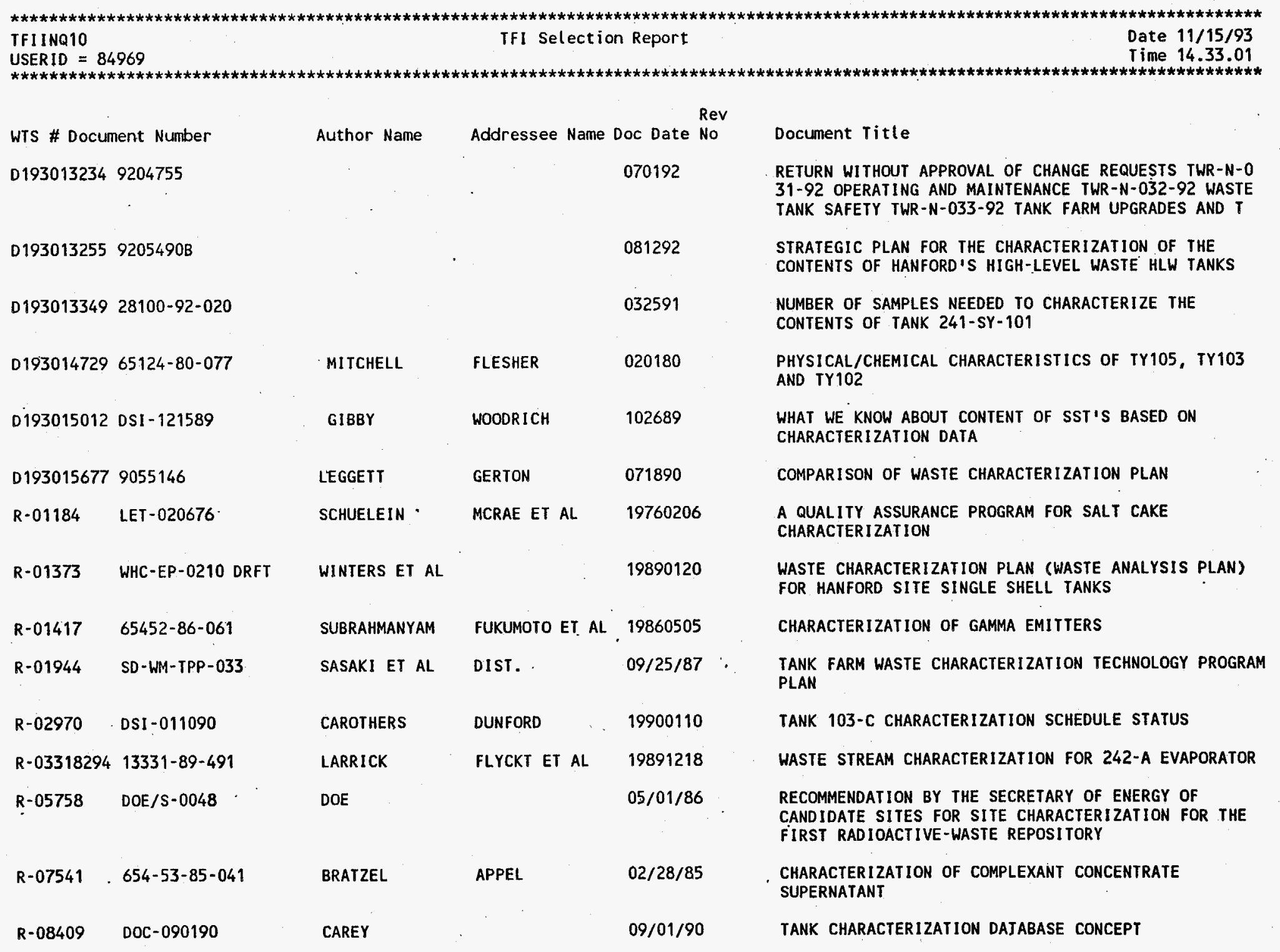


WTS \# Document Number - Author Name Addressee Name Doc Date No

R-08434 DOE/RW-0184-R1 VOLUM DOE

R-08435 DOE/RW-0184-R1 VOLUM DOE

$R-08436$ DOE/RW-0184-R1 VOLUM DOE

$R-08437$ DOE/RW-0184-R1 VOLUM DOE

R-08617 TWR-M-075-92 HARMON

$R-08663 \quad P N L-7758$

$R-08839 \quad H W-39432$

R-09385 DRAFT-090186

$R-09640$ SD-WM-TPP-033

R-09772 PLAN-072689

$R-10212 \quad P R E-041188$

JENSEN

$R-10292 \quad D S-X X X X X X$

$R-10327$ LET-040577

$R-10328 \quad$ LET- 031777

R-10330 LET-032977

R-10341 LET-040177

$R-10343$ LET-040177

R-10344 LET-100474

$R-10345$ LET-040177

R-10346 LET-072277
PETERSON

FOW

SASAKI ET AL.

Addressee Name Doc Date
OAK RIDGE $\quad 07 / 01 / 92$

OAK RIDGE LABOR 07/01/92

OAK RIDGE LABOR 07/01/92

OAK RIDGE LABOR 07/01/92

PUTHOFF

$09 / 14 / 92$

09/01/89

$12 / 01 / 55$

$09 / 01 / 86$

04/05/88 02

CARNAHAN

07/26/89

$04 / 11 / 88$

HORTON
HORTON
HORTON
HORTON
HORTON
HORTON
HORTON
HORTON

$\begin{array}{cc}\text { CHRI SIENSEN } & 04 / 05 / 77 \\ \text { CHRI STENSEN } & 03 / 17 / 77 \\ \text { CHRISTENSEN } & 03 / 27 / 99 \\ \text { CHRISIENSEN } & 04 / 01 / 77 \\ \text { CHRISTENSEN } & 04 / 01 / 77 \\ \text { CHRISTENSEN } & 10 / 04 / 74 \\ \text { CHRISIENSEN } & 04 / 01 / 77 \\ \text { CHRISTENSEN } & 07 / 22 / 77\end{array}$

Document Title

CHARACTERISTICS OF POTENTIAL REPOSITORY WASTES CHARACTERISTICS OF POTENTIAL REPOSITORY WASTES CHARACTERISIICS OF POTENTIAL REPOSITORY WASTES CHARACTERISTICS OF POTENTIAL REPOSITORY WASTES CHANGE REQUEST TWR-M-75-92, "INTEGRATION OF DOUBLE SHELL TANK, SINGLE SHELL TANK CHARACTERIZATION PLANS"

CHARACTERIZATION OF THE FIRST CORE SAMPLE OF NEUTRALIZED CURRENT ACID WASTE FROM DOUBLE SHELL TANK 101-AZ

OPERATIONAL CHARACTERISTICS OF SUBMERGED GAS-LIFT CIRCULATORS

CHARACTERIZATION OF WASTE FROM DOUBLE-SHELL TANK SY -103

TANK FARM CHARACTERIZATION TECHNOLOGY PROGRAM PLAN

PROPOSED CHARACTERIZATION/ASSESSMENT RESEARCH FIVE YEAR RESEARCH, DEVELOPMENT, DEMONSTRATION TESTING AND EVALUATION PROGRAM

HWVP/B PLANT CRITICAL INTERFACES-PART 11 (WASTE CHARACTERIZATION)

200 AREA TREATED EFFLUENT SYSTEM--LIQUID EFFLUENT CHARACTERIZATION DATA
CHARACTERIZATION AND ANALYSIS OF TANK 105-U SLUDGE CHARACTERIZATION OF TANK 104-SX SALTS

CHARACTERIZATION AND ANALYSIS OF TANK 105-SX SALTS CHARACTERIZATION OF TANK 105-C SLUDGE CHARACTERIZATION OF TANK 105-C SLUDGE CHARACTERIZATION OF SX105 SLUDGE SAMPLE CHARACTERIZATION OF TANK 105-C SLUDGE

CHARACTERIZATION AND ANALYSIS OF TANK 106-C 


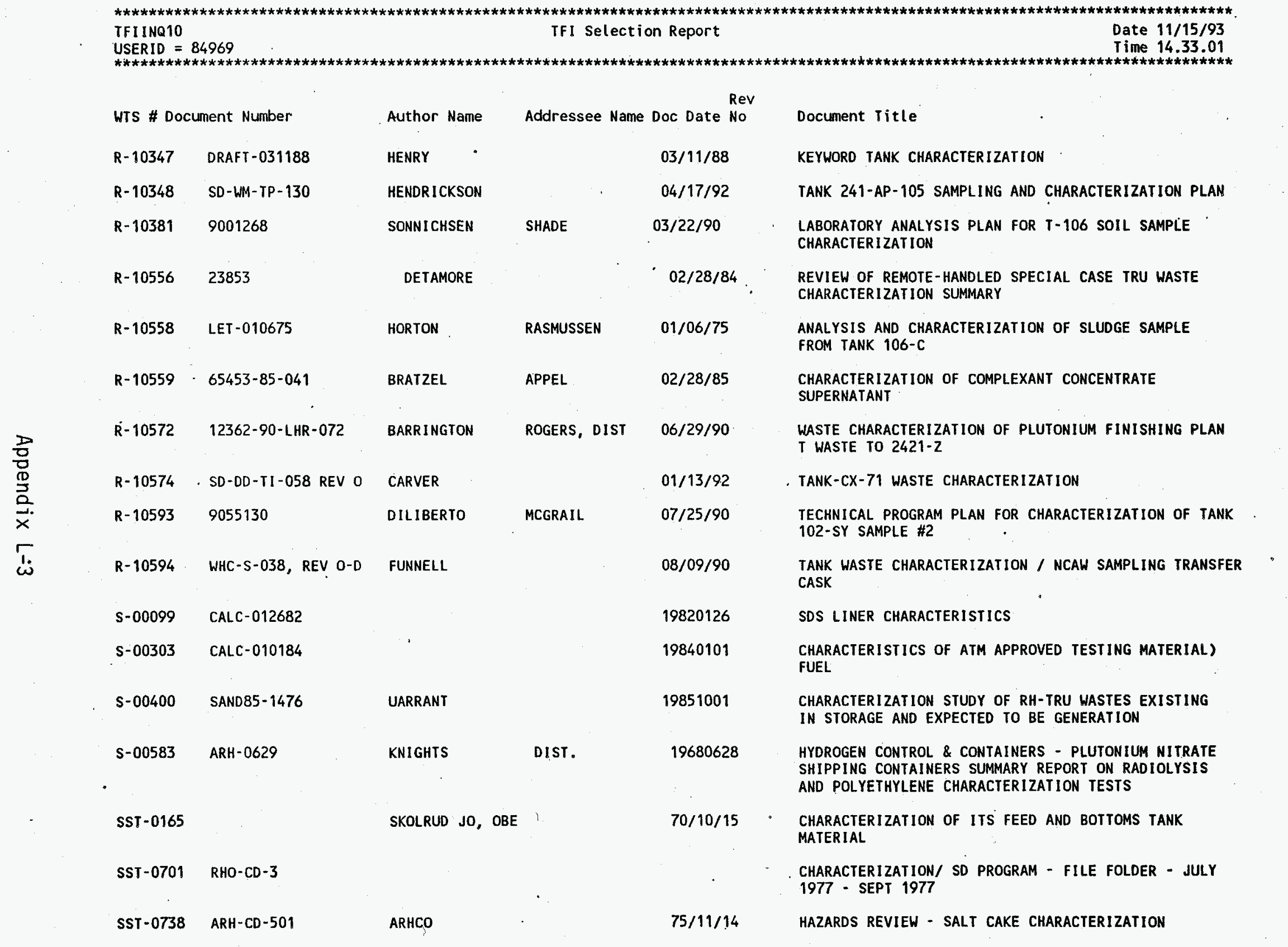




\begin{tabular}{|c|c|c|c|c|c|}
\hline \multicolumn{3}{|c|}{$\begin{array}{l}\text { TFIINQ10 } \\
\text { USERID = } 84969 \\
\star \star \star \star \star \star \star \star * \star * \star * \star * * *\end{array}$} & \multicolumn{2}{|c|}{ TFI Selection Report } & 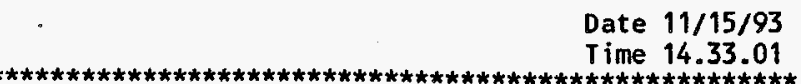 \\
\hline \multicolumn{2}{|c|}{ WTS \# Document Number } & \multirow{2}{*}{$\begin{array}{l}\text { Author Name } \\
\text { RHO }\end{array}$} & \multirow{2}{*}{\multicolumn{2}{|c|}{$\begin{array}{l}\text { Addressee Name Doc Date No } \\
\qquad 80 / 09 / 00\end{array}$}} & \multirow{2}{*}{$\begin{array}{l}\text { Document Title } \\
\text { HANFORD HIGH - LEVEL DEFENSE WASTE CHARACTERIZATION } \\
\text { - A STATUS REPORT }\end{array}$} \\
\hline SST -1077 & RHO-CD- 1019 & & & & \\
\hline SST-1461. & ARH-3059 & ARHCO & & $74 / 04 / 12$ & SALT CAKE WASTE CHARACTERIZZATION PROGRAM \\
\hline SST -1473 & ARH-CD-222 & ARHCO & & $74 / 12 / 04$ & $\begin{array}{l}\text { CHARACTERIZATION OF THE EFFECTS OF DIATOMACEOUS } \\
\text { EARTH ADDITIONS TO HANFORD WASTES }\end{array}$ \\
\hline SST -1518 & $A R H-C D-501$ & ARHCO & & $75 / 11 / 14$ & HAZARDS REVIEW - SALT CAKE CHARACTERIZATION \\
\hline SST-1561 & RHO-CD-962 & RHO & & $80 / 04 / 00$ & $\begin{array}{l}\text { LABORATORY PHYSICAL AND CHEMICAL CHARACTERIZATION } \\
\text { OF HANFORD WASTES - KEY DOCUMENT }\end{array}$ \\
\hline SST -1563 & RHO-CD-1019 & RHO & & $80 / 07 / 00$ & $\begin{array}{l}\text { HANFORD HIGH LEVEL DEFENSE WASTE CHARACTERIZATION } \\
- \text { A STATUS REPORT }\end{array}$ \\
\hline SST-1564 & RHO-CD-1019 & RHO & & $80 / 09 / 00$ & $\begin{array}{l}\text { HANFORD HIGH LEVEL DEFENSE WASTE CHARACTERIZATION } \\
- \text { A STATUS REPORT }\end{array}$ \\
\hline SST -1674 & & ARHCO & & $75 / 09 / 30$ & SLUDGE AND SALT CAKE CHARACTERIZATION PROCESS TEST \\
\hline SST -1683 & & DOE & & & DATA BASE FOR WASTE CHARACTERIZATION \\
\hline SST- 1876 & $65463-80-047$ & RHO & & $80-08-05$ & 241 - TANK FARM CHARACTERIZATION \\
\hline SST-1901 & RHO-HS-ST-1 & RHO & & $82 / 02 / 26$ & $\begin{array}{l}\text { SITE CHARACTERIZATION AND INVENTORY OF HANFORD } \\
\text { DEFENSE WASTE }\end{array}$ \\
\hline SST-5159 & & RHO & & & ANALYSIS AND CHARACTERIZATION OF B361 TANK SLUDGE \\
\hline SST-5212 & QCRN/29639 & RHO & & & C291 STACK CHARACTERIZATION \\
\hline SST-5219 & QCRN/29675 & RHO & & & C291 STACK CHARACTERIZATION \\
\hline$T-00297$ & DSI- 121589 & GIBBY & WODRICH & 19891215 & $\begin{array}{l}\text { WHAT WE KNOW ABOUT CONTENT OF SST BASED ON } \\
\text { CHARACTERIZATION }\end{array}$ \\
\hline$T-00428$ & DSI -053190 & BRATZEL & SLOUGGHTER & 19900531 & SY101 CORE CHARACTERIZATION QA LEVEL \\
\hline$T-00460$ & HU- 27492 & UAGNER & & 19530317 & $\begin{array}{l}\text { INVESTIGATION OF EXPLOSIVE CHARACTERISTICS OF PUREX } \\
\text { SOLVENT DECOMPOSITION PRODUCTS (RED-OIL) }\end{array}$ \\
\hline$T-00484$ & REP-052290 & NONE & NONE & 19900522 & 2.0 CHEMISTRY AND TANK CHARACTERIZATION \\
\hline$T-00567$ & SD-UM-TP-089 REV 0 & EDRINGTON & & 1990081500 & SY101 TANK CHARACTERIZATION TEST PLAN \\
\hline$T-00675$ & UHC-EP-0075 & MORGAN & & 19880701 & SUMMARY OF SST HASTE CHARACTERIZATION 1985 TO 1987 \\
\hline
\end{tabular}


WTS \# Document Number

T-00685 LET -101590

\section{Author Name}

Addressee Name Doc Date No

MORGAN

DEICHMAN

19901015

$\begin{array}{lll}\text { T-00743 } & \text { LET }-031676 & \text { HORTON } \\ \text { T-00803 } & \text { REP }-111490 & \text { KELLER }\end{array}$

$T-01018 \quad 16200-91-003$

JONŚEN ET AL

BABAO ET AL

T-01094 28110-PCL.91-018.

$T-01115 \quad 9100283$

T-01133 LET-022791

T-01193 72100-91-014

T-01226 28100-91-020

T-01239 LET -112888

$T-01270$

LET -100990

$T-01285$

SD-WM-EV-065 REV 0 EACKER

$T-01360$ SD-WM-TP-089 REV 1

$T-01384$ DOE/EA-0511

T-01532

T-01542

LET -120688

T-01584

SD-WM-TP-089 R2

T-01870
BECHTOLD

NEELY

EDRINGTON

HILL

FECHT

JOHNSON

.

19910214

19910227

FOULER

MCDANIEL

19910312

19910325

19881128

WALKER

19901009

KIRCH ET A

199104040

199104191

19910401

19910514

19881206

19910521

09/05/91
Document Title

SUBTASK 4.2 MATERIAL. CHARACTERIZATION MONITORING/ INTERIM REPORT - SUBTASK 4.5 IN-SITU METHODS FOR PASSIVE ACOUSTIC

CHARACTERIZATION AND ANALYSIS OF BY104 TANK SLUDGE

CONCEPTUAL DESIGN FOR THE APPLICATION OF SEAMIST SYSTEM TO CHARACTERIZATION OF HAZARDOUS WASTE STORAGE TANKS

HOW MANY DIFFERENT LOCATIONS IN TANK SYIOI NEED TO BE SAMPLED TO CHARACTERIZE THE CRUST MATERIAL IN THE TANK?

PARTICLE SIZE ANALYSIS DATA FOR U101 SLUDGE CHARACTERIZATION

RCRA GROUND WATER MONITORING AND CHARACTERIZATION SOW FOR ANALYTICAL CHEMISTRY SUPPORT SR101 CHARACTERIZATION

PROJECT U-030 ORGANIC AIRSTREAM CHARACTERIZATION

NUMBER OF SAMPLES NEEDED TO CHARACTERIZE CONTENTS OF SY101 ACTIVITIES MONTHLY REPORT JANUARY 1991

PETROCHEMICALS-SRL-CHARACTERIZATION OF SMOKE FROM KTPB FIRE

CHARACTERIZATION OF SECOND CORE SAMPLE OF NEUTRALIZED CURRENT ACID WASTE FROM DOUBLE SHELL TANK AZ101

A242 EVAPORATOR RESTART FEED CHARACTERIZATION PLAN SY101 TANK WASTE CHARACTERIZATION TEST PLAN CHARACTERIZATION OF SY101 ENVIRONMENTAL ASSESSMENT RECA GROUND WATER MONITORING AND CHARACTERIZATION ACTIVITIES MONTHLY REPORT

FUTURE USE OF SY241 AND PREDICTED VAPOR CHARACTERISTICS

SY101 TANK WASTE CHARACTERIZATION TEST PLAN

SY101 TANK WASTE CHARACTERIZATION TEST PLAN 


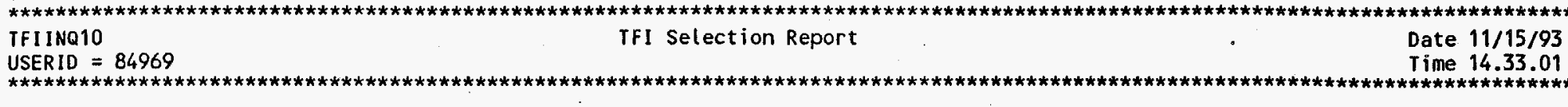

WTS \# Document Number

Author Name

Addressee Name Doc Date No

Document ritle

T-01926 SD-WM-TP-114 REV. 1 BECHTOLD

$12 / 20 / 91$

WASTE CHARACTERIZATION PLAN FOR SAMPLING AND ANALYSIS OF AUGURED SURFACE SAMPLES FROM TANKS CONTAINING FERROCYANIDE WASTE

$\begin{array}{lllll}\text { T-02063 9201812B R1 BELL } & \text { G3/11/92 }\end{array}$

BASIS FOR DELAYS ASSOCIATED WITH ISSUANCE OF WINOOW "C" WASTE CHARACTERIZATION REPORTS AND INITIATIVES TO PREVENT RECURRENCE

$\begin{array}{lllll}\text { T-02380 } & 9105964 B & \text { GERTON } & \text { PRES.,WHC } & 12 / 05 / 91 \\ \text { T-02427 } & \text { WHC-SD-WM-TP-089 } & \text { CRAWFORD } & \text { DIST } & 10 / 21 / 9103 \\ \text { T-02455 } & \text { LET-081192 } & \text { KREITER } & \text { JOHNSON } & 08 / 11 / 92\end{array}$

DRAFT LABORATORY CHARACTERIZATION OF SAMPLES TAKEN IN MAY 1991 FROM HANFORD WASTE TANK 241-SY-101

101-SY TANK WASTE CHARACTERIZATION TEST PLAN

HYDROGEN SAFETY PROJECT (HSP) 101-SY WINDOW E CHEMICAL CHARACTERIZATION RESULTS MILESTONE O302E PARTIAL FULFILLMENT

\begin{tabular}{l}
$\frac{1}{0}$ \\
0 \\
0 \\
0 \\
\hdashline \\
$x$ \\
1 \\
0
\end{tabular}

$\begin{array}{llllc}\text { T-02460 } & \text { WHC-SD-WM-TP-120 } & \text { JEWETT } & \text { DIST } & 08 / 17 / 92 \\ \text { T-02466 } & \text { WHC-SD-WM-DTR-026 } & \text { HERTING } & \text { DIST } & 08 / 18 / 92 \\ \text { T-02520 } & \text { SD-WM-TP-120 } & \text { ANDRINGA } & & 12 / 13 / 91 \\ \text { T-02535 } & \text { SD-WM-DTR-024 } & \text { HERTING } & & 02 / 10 / 92 \\ \text { T-02536 } & \text { LET-071675 } & \text { HORTON } & \text { CHRISTENSEN } & 07 / 16 / 75 \\ \text { Y-08644 } & \text { SD-TD-AP-001 } & \text { MARTIN } & & 07 / 15 / 92 \\ 0020-C & 65453-84-339 & \text { BRATZEL } & & 19841101 \\ 0021-C & 65453-84-344 & \text { BOWTON } & 19841108 \\ 0023-C & 65453-84-354 & \text { BUCKINGHAM } & 19841119 \\ 0026-C & 65630-M R A-012 & \text { ADAMS } & 19841213\end{array}$

ANALYTICAL PLAN AND TEST PLAN FOR CHEMICAL ANALYSIS AND CHARACTERIZATION OF THE WINDOW "E" CORE OF TANK 241-SY-101

LABORATORY CHARACTERIZATION OF SAMPLES TAKEN IN DECEMBER 1991 (WINDOW E) FROM HANFORD WASTE TANK 241SY- 101

ANALYTICAL PLAN AND TEST PLAN FOR CHEMICAL ANALYSIS AND CHARACTERIZATION OF THE WINDOW "E" CORE OF TANK 241-SY-101, (WHC-SD-WM-TP-120 REV.0)

LABORATORY CHARACTERIZATION OF SAMPLES TAKEN IN MAY 1991 FROM HANFORD WASTE TANK 241-SY-101

ANALYSIS AND CHARACTERIZATION OF SLUDGE FROM TANK 101 - S

ACTIVITY PLAN FOR THE INTEGRATED INSTRUMENT PLATFORM FOR IN SITU CHARACTERIZATION OF TANK WASTES

WASTE TANK CHARACTERIZATION ANALYSES

TEST TO DETERMINE CORE DRILLING PRECISION AND PRESERVATION OF SEGMENT INTEGRITY TO SUPPORT THE WASTE TANK CHARACTERIZATION PROGRAM

WASTE TANK CHARACTERIZATION ARCHIVED SAMPLES

ALTERNATE APPROACHES TO SINGLE-SHELL. TANK

CHARACTERIZATION AND THE VALIDATION OF. THE TRAC MOOEL: PRELIMINARY LOGIC AND CRITERIA 


\begin{tabular}{|c|c|c|c|c|c|}
\hline \multicolumn{2}{|c|}{ WTS \# Document Number } & Author Name & Addressee Name & Doc Date No & Document Title \\
\hline 0029-C & $65453-85-023$ & BOWRON & & 19850201 & $\begin{array}{l}\text { EVALUATION OF CHLOROFLUOROCARBON } 113 \text { WASTE TANK } \\
\text { CHARACTERIZATION }\end{array}$ \\
\hline $0031-\mathrm{C}$ & $65453-85-066$ & BOWTON ET AL & & 19850402 & $\begin{array}{l}\text { ESTIMATED LABORATORY COSTS FOR ANALYSIS OF WASTE } \\
\text { TANK CHARACTERIZATION SAMPLES }\end{array}$ \\
\hline 0049-C & $65000-W W S-87-021$ & SCHULZ & & 19870324 & $\begin{array}{l}\text { KEYWORDS AND SUBKEYWORDS FOR SINGLE-SHELL TANR } \\
\text { CHARACTERIZATION RECORDS }\end{array}$ \\
\hline 0052-C & SO-WM-LB-005 & BOWTON ET AL. & & 19850509 A0 & $\begin{array}{l}\text { WASTE TANK CHARACTERIZATION LABORATORY QUALITY } \\
\text { ASSURANCE PLAN }\end{array}$ \\
\hline $0054-C$ & RHO-CD -573 & GRIMES & & 19781201 RO & $\begin{array}{l}\text { HANFORD DEFENSE HIGH-LEVEL WASTE SAMPLING AND } \\
\text { CHARACTERIZATION PLAN: KEY DOCUMENT }\end{array}$ \\
\hline 0056-C & RHO-CD-962 & MITCHELL & & 19800401 & $\begin{array}{l}\text { LABORATORY PHYSICAL AND CHEMICAL CHARACTERIZATION } \\
\text { OF HANFORD WASTES: KEY DOCUMENT }\end{array}$ \\
\hline 0066-C & RHO-CD-137 & GRIMES & & 19771001 & $\begin{array}{l}\text { HANFORD LONG-TERM DEFENSE HIGH-LEVEL WASTE } \\
\text { MANAGEMENT PROGRAM WASTE SAMPLING AND CHARACTERIZATION } \\
\text { PLAN }\end{array}$ \\
\hline $0067-\mathrm{C}$ & ARH-CD-571 & & & 19760301 & $\begin{array}{l}\text { SALT CAKE CHARACTERIZATION LABORATORY STATUS } \\
\text { REPORT }\end{array}$ \\
\hline $0069-\mathrm{C}$ & RHO-CD- 1019 & JUNGFLEISCH - & & 19800901 & $\begin{array}{l}\text { HANFORD HIGH LEVEL DEFENSE WASTE CHARACTERIZATION } \\
\text { A STATUS REPORT }\end{array}$ \\
\hline $0077-\mathrm{C}$ & $12510-85-155$ & SVANCARA & & 19850611 & $\begin{array}{l}\text { 222-S ANALYTICAL LABORATORY ABILITY TO SUPPORT } \\
\text { WASTE TANK CHARACTERIZATION PROGRAM (WTCP) }\end{array}$ \\
\hline 0082-C & $65453-80-265$ & BRATZEL & & 19800918 & $\begin{array}{l}\text { EVALUATION OF WASTE STORAGE TANK PHYSICAL AND } \\
\text { CHEMICAL CHARACTERIZATION DATA }\end{array}$ \\
\hline D085-C & $65453-83-289$ & BRATZEL & & 19831111 & $\begin{array}{l}\text { IDENTIFICATION OF CHEMICAL AND PHYSICAL ANALYSES } \\
\text { IN SUPPORT OF WASTE TANK CHARACTERIZATION }\end{array}$ \\
\hline $0087-\mathrm{C}$ & $65453-85-123$ & BOWTON & & 19850619 & $\begin{array}{l}\text { POTENTIAL TOTAL ORGANIC CARBON ANALYSIS CORRUPTION } \\
\text { IN WASTE TANK CHARACTERIZATION SAMPLES }\end{array}$ \\
\hline $0089-\mathrm{C}$ & ARH-CD-682 & & & $19760601 \mathrm{AO}$ & $\begin{array}{l}\text { SALT CAKE AND SLUDGE CHARACTERIZATION ANALYTICAL } \\
\text { NEEDS }\end{array}$ \\
\hline $0091-\mathrm{C}$ & SD-WM-QA-001 & IBSEN & & $19840621 \cdot \mathrm{AO}$ & $\begin{array}{l}\text { ANALYTICAL LABORATORIES MEASUREMENI CONIROL } \\
\text { PLAN FOR WASTE TANK CHARACTERIZATION }\end{array}$ \\
\hline $0105-\mathrm{C}$ & & BOWTION & & 19840827 & MEETING MINUTES: WASTE TANK CHARACTERIZATION \\
\hline 0116-C & & IBSEN & & 19840403 & $\begin{array}{l}\text { MEETING MINUTES: WASTE TANK CHARACTERIZATION } \\
\text { PROGRAM (WTCP) }\end{array}$ \\
\hline
\end{tabular}


WTS \# Document Number

$0117-\mathrm{C}$

0137-C SD-WM-LB-004

0139-C

0140-c

0141-C

SD-UM-PD-024

0143-C

$65453-85-228$

0149-C

0152-C

0155-C

0157-C

0160-C

0162-C SD-WM-TI-233

0165-C $\quad 65451-86-061$

0166-C 65451-86-096

0173-c

$0174-C$

0175-C
Author Name

IBSEN

BOWTON ET AL

ANDERSON

SCHULZ

JUNGFLEISCH

WEISS

WEISS

SCHULZ

SCHULZ

JENSEN

JENSEN

SCHULZ

SCHULZ

ROGERS
Addressee Name Doc Date No

19840326

19841004 AO

19851111

19851101

AO

19851126

19860321

19851016

19860328

19860301

19860401

19860508 A0

19860415

19860529

19861028

19861001

19860611
Document Title

MEETING MINUTES: WASTE TANK CHARACTERIZATION PROGRAM (WTCP)

WASTE TANK CHARACTERIZATION PROGRAM SAMPLE HANDLING AND ANALYSIS PLAN . (LABORATORY CUSTOMER COMMUNICATIONS SYSTEM)

SINGLE-SHELL TANK CHARACTERIZATION TEAM FY 1986 MEETING 1

CHARACTERIZATION OF SINGLE-SHELL TANK (SST) WASTES: PHILOSOPHY AND PRINCIPLES

SINGLE-SHELL TANK (SST) WASTE CHARACTERIZATION. COST STUDY: COMMENT COPY

ARCHIVE STORAGE OF WASTE TANK CHARACTERIZATION SAMPLES

TY TANK FARM WASTE CHARACTERIZATION DATA REPORT: PRELIMINARY EVALUATION TO SUPPORT TESTING DOMEFILLING TECHNOLOGY

SST CHARACTERIZATION TEAM AGENDA: MEETING NUMBER SINGLE-SHELL TANK WASTE CHARACTERIZATION TEAM: QUARTERLY MEETING

CHARACTERIZATION OF SINGLE-SHELL TANK WASTES: STATUS AND PLANS

LETTER REPORT: PRELIMINARY ANALYSIS OF RADIONUCLIDE INVENTORY REQUIREMENTS FOR CHARACTERIZATION OF HANFORD SINGLE-SHELL TANK WASTES

STRATEGY FOR CHARACTERIZATION OF SINGLE-SHELL TANKS: FY 1985 SUMMARY REPORT

PRELIMINARY LISTS OF SSTS FOR WASTE CHARACTERIZATION

RANDOMLY SELECTED SSTS FOR WASTE CHARACTERIZATION

CHARACTERIZATION OF WASTES IN SINGLE-SHELL TANKS: STATUS AND PROGRESS REPORT

INGLE-SHELL TANK WASTE CHARACTERIZATION TEAM AGENDA: OCTOBER 1986

PRELIMINARY ANALYSIS OF RADIONUCLIDE INVENTORY

REQUIREMENTS FOR CHARACTERIZATION OF HANFORD SINGLE- 
WTS \# Document Number

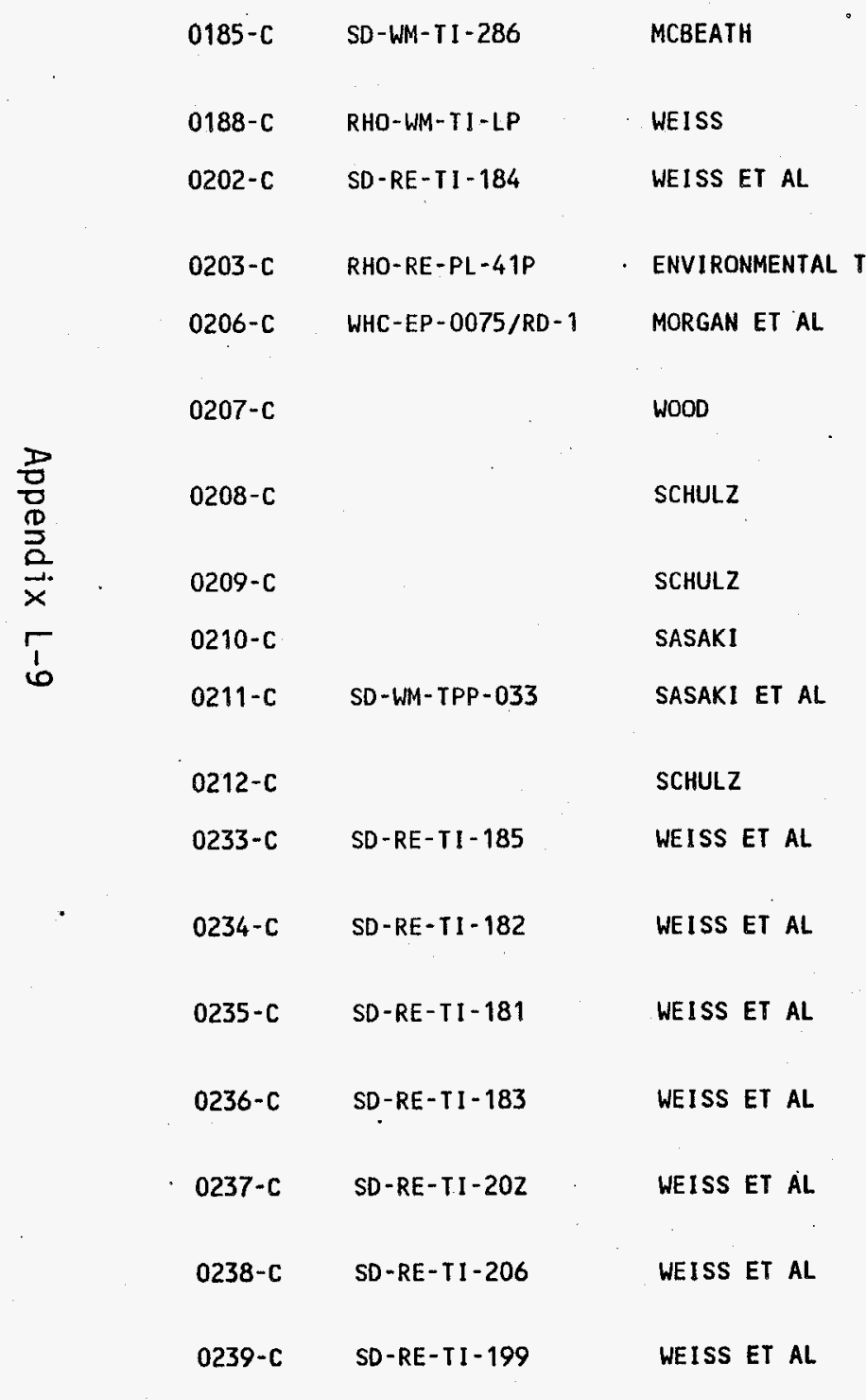

Rev

Addressee Name Doc Date No
Document Title

SHELL TANK WASTE

19870112 AO COST BENEFIT ANALYSIS: COMPOSITE CORE SAMPLING FOR HANFORD WASTE TANK CHARACTERIZATION

19860301

TY TANK FARM WASTE CHARACTERIZATION DATA

19870630 AO DATA IRANSMITTAL PACKAGE FOR 241-TY-103 WASTE TANK CHARACTER IZATION

19870301 SINGLE-SHELL TANK WASTE CHARACTERIZATION PLAN

19870901

19871029

19871019

19871103

19871123

198710925 RO

STRATEGY FOR CHARACTERIZATION OF SINGLE-SHELL TANK WASTE: SUMMARY REPORT

WASTE MANAGEMENT CONSULTANTS PANEL COMMENTS ON SST CHARACTERIZATION

SINGLE-SHELL TANK WASTE CHARACTERIZATION TEAM MEETING \#L

SINGLE-SHELL TANK CHARACTERIZATION TEAM MEETING \#2 SINGLE-SHELL TANK CHARACTERIZATION TECHNICAL ISSUES TANK FARM WASTE CHARACTERIZATION TECHNOLOGY PROGRAM PLAN

19871201 SINGLE-SHELL TANK CHARACTERIZATION TEAM MEETING \#

19870708 AO DATA TRANSMITTAL PACKAGE FOR 241-BY-101, WASTE TANK CHARACTERIZATION

19870630 AO OATA TRANSMITTAL PACKAGE FOR 241-TY-104 WASTE TANK CHARACTERIZATION

19870708 AO DATA TRANSMITTAL PACKAGE FOR 241-TY-106, WASTE TANK CHARACTERIZATION

19870630 AO DATA TRANSMITTAL PACKAGE FOR 241-TY-102, WASTE TANK CHARACTERIZATION

19880121 AO

DATA TRANSMITTAL PACKAGE FOR 241-BX-105, WASTE TANK CHARACTERIZATION

19880121 A0 DATA TRANSMITTAL PACKAGE FOR 241-BX-104, WASTE TANK CHARACTERIZATION

19880121 AO DATA TRANSMITTAL. PACKAGE FOR 241-C-104, WASTE TANK CHARACTERIZATION 


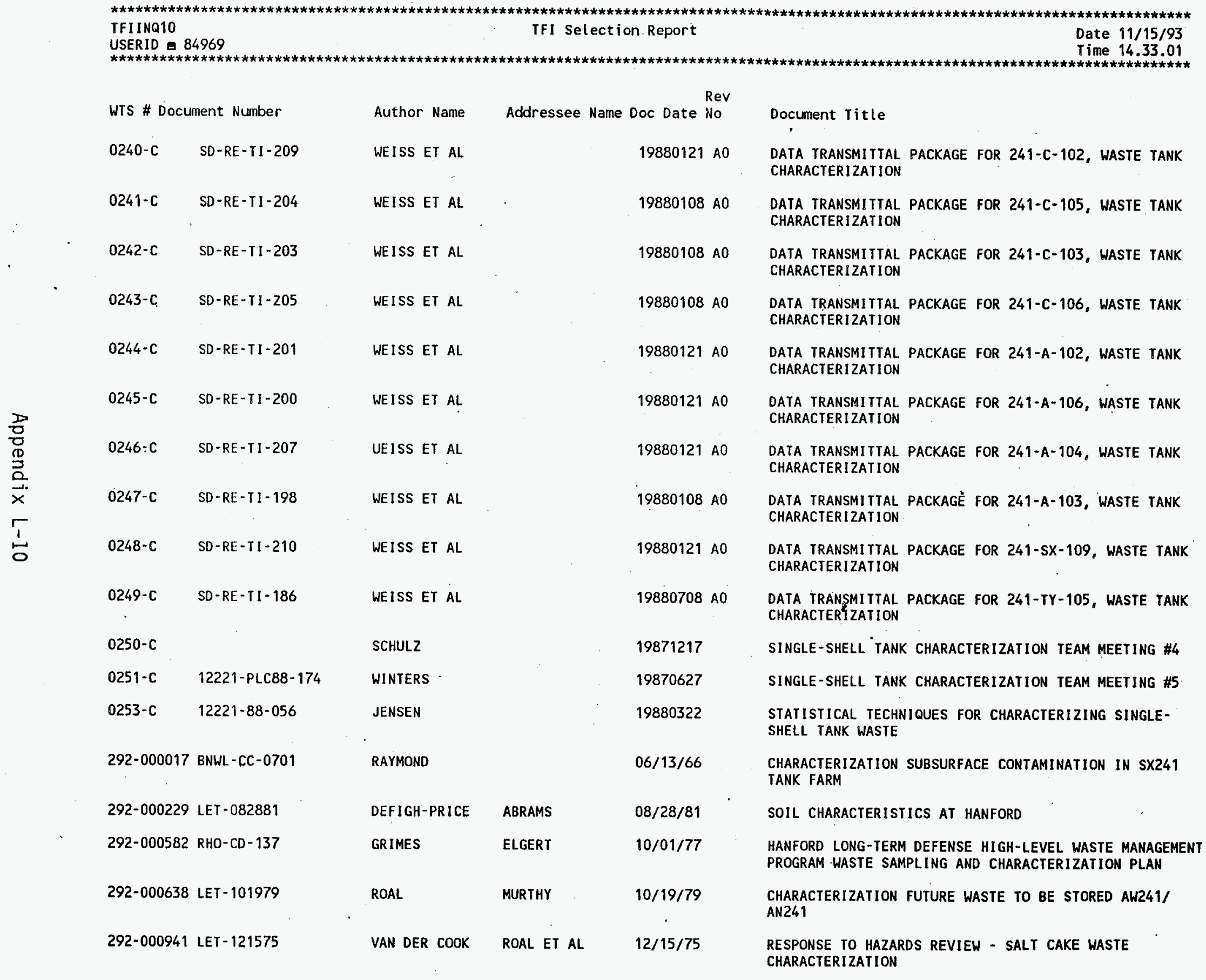


WTS \# Document Number

292-000942 LET-010576

292-000943 LET-011376

292-000944 LET-011576

292-000945 LET-021676

292-000983 LET-120779

292-001018 PNL-7258

292-001069 SD-RE-TI-202

292-001070 SD-RE-TI-206

292-001071 SD-RE-TI-209

292-001196 13331-88-018

292-001207 WHC-EP-0210 DRAFT

292-001208 WHC-EP-0210 VOL 1 \& WINTERS ET AL

292-001209 WHC-EP-0210

292-00121D WHC-EP-D210 REV 2

292-001224 WHC-EP-0210, REV 1

292-001238 DRAFT-012076

292-001359 DSI-D81588

29Z-001363 P.RE-050187

292-001365 PRE-050187
Author Name Addressee Name Doc Date No

ALLEN DIST. $\quad 01 / 05 / 76$

BABAD ALLEN ET AL $01 / 13 / 76$

MCRAE

MCRAE

ROAL

HARA ET AL.

ALLEN ET AL $01 / 15 / 76$

SCHUELEIN ET AL 02/16/76

MURTHY

$12 / 07 / 97$

UEISS ET AL

DIST.

WEISS ET AL

DIST.

$01 / 21 / 88 D$

WEISS ET AL

DIST.

$01 / 21 / 80$

$01 / 21 / 88$

$01 / 20 / 88$

$01 / 20 / 89$

$.08 / 01 / 90$

$12 / 31 / 92$

$12 / 31 / 90$

$12 / 00 / 901$

TANAKAHAM

WOOD

SCHULZ

WEISS

05/01/87

$05 / 01 / 87$
Document Title

SALT CAKE AND SLUDGE CHARACTERIZATION PROGRAM PLAN SALT CAKE AND SLUDGE CHARACTERIZATION PROGRAM PLAN COMMENTS ON SALT CAKE AND SLUDGE CHARACTERIZING PROGRAM PLAN

A QUALITYY ASSURANCE PROGRAM FOR SALT CAKE CHARACTERIZATION

CHARACTERIZATION OF FUTURE WASTE TO BE STORED AW241/AN241

SST SAMPLE CHARACTERIZATION ANALYSIS OF ARCHIVE SAMPLES C102, C105 AND C106

DTP FOR BX105 WASTE TANK CHARACTERIZATION

DTP FOR BX104 WASTE TANK CHARACTERIZATION

DTP FOR C102 WASTE TANK CHARACTERIZATION

TANK 103-C CHARACTERIZATION INTERIM STATUS

WASTE CHARACTERIZATION PLAN (WASTE ANALYSIS PLAN) FOR THE HANFORD SITE SINGLE-SHELL TANKS

WASTE CHARACTERIZATION PLAN FOR HANFORD SITE SINGLE SHELL TANKS

WASTE CHARACTERIZATION PLAN FOR HANFORD SITE SINGLE SHELL TANKS

WASTE CHARACTERIZATION PLAN FOR HANFORD SITE SINGLE SHELL TANKS

WASTE CHARACTERIZATION PLAN FOR HANFORD SITE SINGLE SHELL TANKS

WASTE CHARACTERISTICS FOR DOUBLE-SHELL TANK PUMPS

REVIEW OF SINGLE SHELL TANK CHARACTERIZATION BASED ON TRAC COMPUTER MODEL" SINGLE SHELL TANK WASTE CHARACTERIZATION UTILIZATION OF TRAC MODEL 


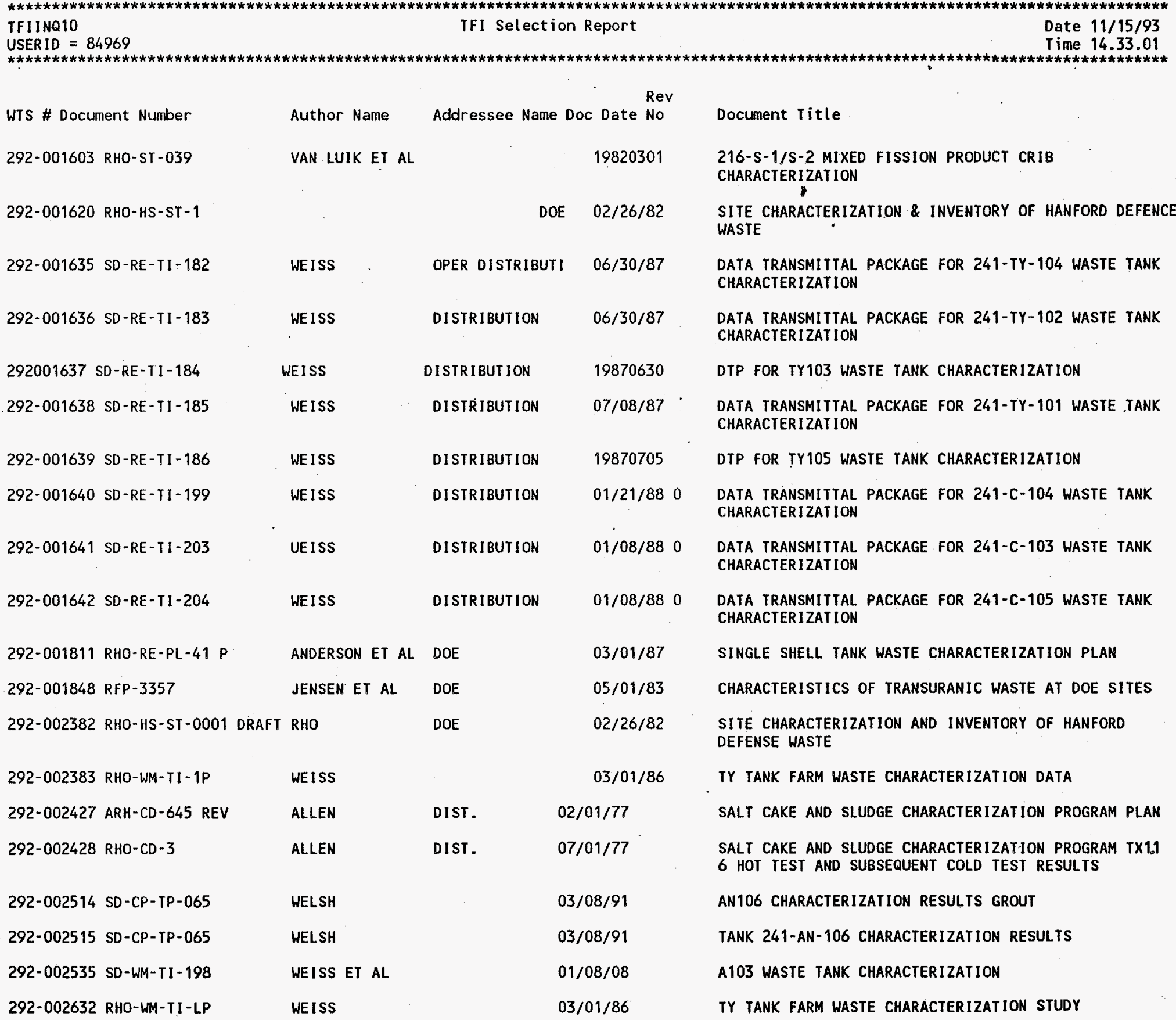


WTS \# Document Number

292-002863 65453-85-023

Author Name

BOWTON

Addressee Name Doc Date No

292-002935 DSI-110690

292-0029479000845

$\infty$

292-0029519000855

292-003000 89-246-SIA

292-003309 13230-89-TDB-0088

292-003310 13800-88-GTD-0041

292-00940 DRAFT-091575

29201196 13331-88-018

293-000048 DSI-060889

293-000051 13331-89-020

293-000055 PRE- XXXXXXX

293-000057 13331-88-034

293-000059 PAPER-XXXXXXX

293-000060 REP-011388

293-000063 MM-101287

293-000064 MM-082787

293-000065 PRE-XXXXXXX

293-000066 MM-092287

293-000067 MM-091487

$\begin{array}{lll}\text { HICKEY } & \text { DISTRIBUTION } & 11 / 06 / 90 \\ \text { PETERSON } & \text { DILIBERTO } & 02 / 16 / 90\end{array}$

PETERSON

DILIBERTO

$02 / 12 / 90$

ANDERSON

SCHADE

$08 / 22 / 89$

BLANKENSHIP

DUNFORD

$03 / 21 / 89$

DUKELOW

VAN DER COOK

DIST

$12 / 16 / 88$

SCHUELEIN ET AL 09/15/75

CATOTHERS

DIST.

$01 / 20 / 88$.

CAROTHERS

CAROTHERS

WASHENFELDER ET $01 / 18 / 89$

CAROTHERS

FOREHAND ET AL $01 / 21 / 88$

$01 / 13 / 88$

CAROTHERS

CAROTHERS

DIST

$10 / 12 / 87$

CAROTHERS

DIST

09/22/87

CAROTHERS
DIST

$09 / 14 / 87$
Document Title

EVALUATION OF CHLOROFLUOROCARBON 113 FOR WASTE TANK CHARACTERIZATION

VAPOR SPACE CHARACTERIZATION PLAN MEETING REVIEW

PRELIMINARY RESULTS - PHYSICAL AND RHEOLOGICAL CHARACTERIZATION OF THE AS-RECEIVED WASTE FROM DST 101-AZ CORE \#2

REVISED REPORT ON THE RESULTS OF 102-AY CHARACTERIZATION

SITE CHARACTERIZATION REQUIREMENTS FOR SY102 WASTE SOLUTION PRIOR TO CROSS SITE TRANSFER TO AY101

RADIONUCLIDE CHARACTERIZATION QUESTIONNAIRE ACTION ITEM NO 596

RADIONUCLIDE CHARACTERIZATION QUESTIONNAIRE

PROPOSED ANALYTICAL STANDARDS AND REQUIREMENTS FOR WASTE CHARACTERIZATION

TANK C103 CHARACTERIZATION INTERIM STATUS

LOGICAL STOPPING POINT FOR THE TANK C103

CHARACTERIZATION PROJECT

TANK C103 CHARACTERIZATION FISCAL YEAR 1989 WORK SCOPE

TANK C103 CHARACTERIZATION

TANK C103 CHARACTERIZATION FISCAL YEAR 1988 WORK SCOPE

TANK C103 CHARACTERIZATION PROJECT COST BREAKDOWN TANK C103 CHARACTERIZATION STATUS

TANK C103 CHARACTERIZATION TASK FORCE

TANK C103 CHARACTERIZATION TASK FORCE

TANK C103 CHARACTERIZATION

TANK C103 CHARACTERIZATION TASK FORCE

TANK C103 CHARACTERIZATION TASK FORCE 


\begin{tabular}{|c|c|c|c|c|}
\hline 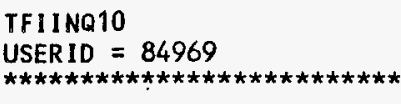 & 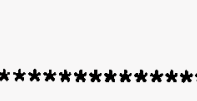 & $\begin{array}{r}\text { TFI Selectio } \\
* * \star * * * * * * \star * * * * * *\end{array}$ & $\begin{array}{l}\text { on Report } \\
\star \star \star \star \star \star \star \star \star \star \star \star \star * \star *\end{array}$ & 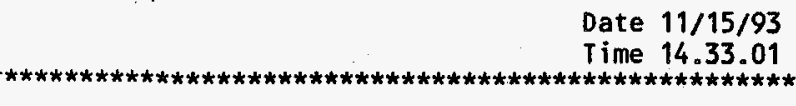 \\
\hline WTS \# Document Number & Author Name & Addressee Name & Doc Date No & Document Title \\
\hline $293-000068$ MM-100187 & CAROTHERS & DIST & $10 / 01 / 87$ & TANK C103 CHARACTERIZATION TASK FORCE \\
\hline 293-000069 МM-091087 & CAROTHERS & DIST & $09 / 10 / 87$ & TANK C103 CHARACTERIZATION TASK FORCE \\
\hline 293-000070 PRE-090987 & & & $09 / 09 / 87$ & TANK C103 CHARACTERIZATION \\
\hline 293-000071 MM-082687 & CAROTHERS & DIST & $08 / 26 / 87$ & TANK C103 CHARACTERIZATION TASK FORCE \\
\hline 293-000072 DSI-090487. & CAROTHERS & DIST & $09 / 04 / 87$ & TANK C103 CHARACTERIZATION ACTION PLAN \\
\hline $293-000073$ DS1-090887 & CAROTHERS & DIST & $09 / 08 / 87$ & $\begin{array}{l}\text { AGENDA FOR NEXT TANK C103 CHARACTERIZATION TASK } \\
\text { FORCE MEETING }\end{array}$ \\
\hline $293-000323 \quad 13331-89-491$ & LARRICK & FLYCKT ET AL & $12 / 18 / 89$ & WASTE STREAM CHARACTERIZATION FOR 242-A EVAPORATOR \\
\hline $293-002046$ MM- 113088 & CAROTHERS & DIST & $11 / 30 / 88$ & TANK C103 CHARACTERIZATION TASK FORCE \\
\hline $293-002189.28200-91-044$ & KEELE & JEPPSON & $06 / 17 / 91$ & $\begin{array}{l}\text { STATUS OF THE RADIOLOGICAL CHARACTERIZATION OF } \\
241-\mathrm{BY}-104\end{array}$ \\
\hline $293-002525$ FAX-120387 & PETERSON & DILIBERTO & $12 / 03 / 87$ & WASTE CHARACTERIZATION OF DST'S AZ101 AND AZ102 \\
\hline $293-002976$ SD-DD-TI -040 & CUMMINGS & & $07 / 09 / 79$ & TANK 241-CX-72 PRELIMINARY WASTE CHARACTERIZATION \\
\hline 293-002996 ARHC- 111676 & HORTON & CHRISTENSEN & $11 / 16 / 76$ & ANALYSIS AND CHARACTERIZATION OF 361-B TANK SLUDGE \\
\hline $293-00305865120-79-113 \mathrm{~J}$ & HORTON & MIRABELLA & $07 / 23 / 79$ & CHARACTERIZATION OF TANK 361-B \\
\hline 293-003105 ARHC-053174. & PEABODY & HARLOW & $05 / 31 / 74$ & $\begin{array}{l}\text { CHARACTERIZATION OF } 316-2-8 \text { TANK AND } 361-2 \text { SETTLING } \\
\text { TANK }\end{array}$ \\
\hline $293-00315665120-79-113 \mathrm{~J}$ & HORTON & MIRABELLA & $07 / 23 / 79$ & CHARACTERIZATION OF TANK 361-B \\
\hline 293-003175 DOE/RW-0006 & & DISTRIBUTION & $10 / 01 / 906$ & $\begin{array}{l}\text { INTEGRATED DATA BASE FOR 1990: U.S. SPENT FUEL AND } \\
\text { RADIOACTIVE WASTE INVENTORIES, PROJECTIONS, AND } \\
\text { CHARACTERISTICS SECTION } 1 \text { OF } 3\end{array}$ \\
\hline 293-003186 DOE/RW-0006 & & DISTRIBUTION & $10 / 01 / 906$ & $\begin{array}{l}\text { INTEGRATED DATA BASE FOR } 1990: \text { U.S. SPENT FUEL AND } \\
\text { RADIOACTIVE WASTE INVENTORIES, PROJECTIONS, AND } \\
\text { CHARACTERISTICS SECTION } 2 \text { OF } 3\end{array}$ \\
\hline 293-003187 DOE/RW-0006 & & DISTRIBUTION & $10 / 01 / 906$ & $\begin{array}{l}\text { INTEGRATED DATA BASE FOR } 1990: \text { U.S. SPENT FUEL } \\
\text { RADIOACTIVE WASTE INVENTORIES, PROJECTIONS, AND } \\
\text { CHARACTERISTICS SECTION } 3 \text { OF } 3\end{array}$ \\
\hline 293-003205 SD-WM-TPP-033 & SASAKI & ADAMS & $09 / 25 / 87$ & $\begin{array}{l}\text { TANK FARM WASTE CHARACTERIZATION TECHNOLOGY PROGRAM } \\
\text { PLAN SECTION } 1 \text { OF } 2\end{array}$ \\
\hline 293-003206 SD-WM-TPP-033 & SASAKI & - & $09 / 25 / 87$ & $\begin{array}{l}\text { TANK FARM WASTE CHARACTERIZATION TECHNOLOGY PROGRAM } \\
\text { PLAN SECTION } 2 \text { OF } 2\end{array}$ \\
\hline
\end{tabular}




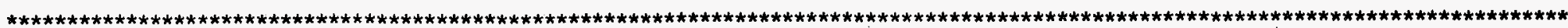

TFIINQ10

TFI Selection Report

Date $11 / 15 / 93$

USERID $=84969$

WTS \# Document Number

293-003280 WHC-EP-0210

293-003334 PB85-168771 VOL 2 FORD

$293-003426$ PB85-168771 VOL 2 FORD

293-003457 8902770

293-003480 DOE/RW-0006

293-003481 DOE\RW-0006

293-003485 DOE/RW-0006

293-003486 DOE/NE-0017-1

293-003487 DOE/RW-0017-1

293-003489 DOE/RW-0017-1

293-003490 DOE/RW-0017-1

293-003509 DOE/NE-0017/2

293-003511 DOE/RW-0006
Author Name

HIL

FORD

SCHEELE

PETERSON

DILIBERTO

Addressee Name Doc Date No

09/01/913

$12 / 01 / 84$

$12 / 01 / 84$

$12 / 01 / 84$

$06 / 01 / 89$

$12 / 01 / 8501$

$12 / 01 / 851$

$12 / 01 / 85 \quad 1$

$10 / 01 / 82$

$10 / 01 / 82$

$10 / 01 / 82$

$10 / 01 / 82$

$09 / 01 / 83$

THEREAULT

$09 / 01 / 84$
Document Title

WASTE CHARACTERIZATION PLAN FOR THE HANFORD SITE SINGLE-SHELL TANKS APPENDIX I - TEST PLAN FOR SAMPLINC AND ANALYSIS OF TEN SINGLE-SHELL TANKS

CHARACTERIZATION OF HAZARDOUS WASTE SITES- A METHODS MANUAL- VOLUME 11, AVAILABLE SAMPLING METHODS。 SECOND EDITION SECTION 2 OF 3

CHARACTERIZATION OF HAZARDOUS WASTE SITES A METHOD MANUAL--VOLUME 11, AVAILABLE SAMPLING METHODS, SECOND EDITION

CHARACTERIZATION OF HAZARDOUS WASTE SITES A METHOD MANUAL - - VOLUME 11 , AVAILABLE SAMPLING METHODS, SECOND EDITION SECTION 3 OF 3

RESULTS OF THE CHARACTERIZATION OF SAMPLES OF WASTE FROM DOUBLE-SHELL TANK 102-SY

LETTER REPORT - RESULTS OF THE CHARACTERIZATION OF SAMPLES OF WASTE FROM DOUBLE-SHELL TANK 102-SY

SPENT FUEL AND RADIOACTIVE WASTE INVENTORIES, PROJECT LONS, AND CHARACTERISTICS SECTION 1 OF 3

SPENT FUEL AND RADIOACTIVE WASTE INVENTORIES PROJECTIONS, AND CHARACTERISTICS SECTION 2 OF 3

SPENT FUEL AND RADIOACTIVE WASTE INVENTORIES PROJECTIONS, AND CHARACTERISTICS SECTION 3 OF 3 SPENT FUEL AND RADIOACTIVE WASTE INVENTORIES, PROJECTIONS, AND CHARACTERISTICS

SPENT FUEL AND RADIOACTIVE WASTE INVENTORIES, PROJECTIONS, AND CHARACTERISTICS SECTION 2 OF 4

SPENT FUEL AND RADIOACTIVE WASTE INVENTORIES PROJECTIONS, AND. CHARACTERISTICS SECTION 3 OF

SPENT FUEL AND RADIOACTIVE WASTE INVENTORIES, PROJECTIONS, AND CHARACIERISTICS SECTION 4 OF 4

SPENT FUEL AND RADIOACTIVE WASTE INVENTORIES PROJECTIONS, AND CHARACTERISTICS SECTION 2 OF 3 


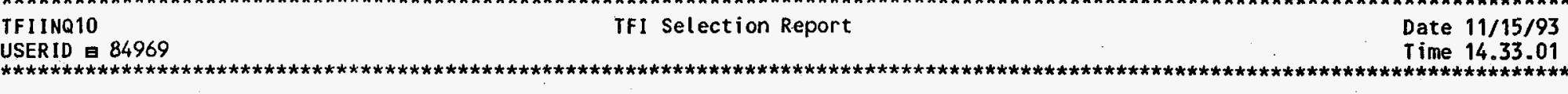

WTS \# Document Number

293-003513 DOE/RW-0006

293-003515 DOE/NE-0017/2

293-003554 ECN-163837

293-003651 DOE/NE-0017/2

293-003664 WHC-EP-0133

293-003966 LETTER-042792

293-004056 DOE/RW-0006

293-004099 DOE/RW-0006

293-004102 DOE/RW-0006

293-004147 DOE/RW-0006

293-004155 DSI-111987

293-004465 DOE/RW-0006

293-004515 DOE/RW-0006

293-004518 DOE/RW-0006

$293-004612 \quad 12500-92-052$
Author Name

Addressee Name Doc Date No

$09 / 01 / 84$

THEREAULT

HENDERSON

$09 / 01 / 83$

03/06/92

$09 \% 01 / 83$

$06 / 01 / 88$

BAKER

GASPER

NOONAN

$04 / 27 / 92$

$09 / 30 / 884$

$09 / 01 / 88 \quad 4$

$11 / 01 / 895$

$09 / 01 / 84$

SCOTt

WOLFE

$11 / 19 / 87$

$11 / 30 / 895$

$09 / 01 / 862$

$09 / 01 / 873$

DODD
Document Title

SPENT FUEL AND RADIOACTIVE WASTE INVENTORIES PROJECTIONS, AND CHARACTERISTICS SECTION 2 OF 3

SPENT FUEL AND RADIOACTIVE WASTE INVENTORIES, PROJECTIONS, AND CHARACIERISTICS; SECTION 3 OF 3 TANK AP106 SAMPLING AND CHARACTERIZATION PLAN ENGINEER ING CHANGE NOTICE

SPENT FUEL AND RADIOACTIVE WASTE INVENTORIES, PROJECIIONS, AND CHARACTERISTICS SECTION 1 Of 3

U1/U2 URANIUM PLUME CHARACTERIZATION, REMEOIAL ACTION REVIEW AND RECOMMENDATION FOR FUTURE ACTION

WASTE TANK SAFETY PROGRAMS TANK CHARACTERIZATION REQUIREMENTS

SPENT FUEL AND RADIOACTIVE WASTE INVENTORIES, PROJECTIONS, AND CHARACTERISTICS

INTEGRATED DATA BASE FOR 1988: SPENT FUEL AND RADIOACTIVE WASTE INVENTORIES PROJECTIONS, AND CHARACTER ISTICS

INTEGRATED DATA BASE FOR 1989: SPENT FUEL AND RAD IOACTIVE WASTE INVENTORIES, PROJECTIONS, AND CHARACTERISTICS

SPENT FUEL AND RADIOACTIVE WASTE INVENTORIES, PROJECTIONS, AND CHARACTERISTICS SECTION 3 OF 3 CHARACTERIZATION OF HANFORD WASTE VITRIFICATION PLANT WASTE FEED

INTEGRATED DATA BASE FOR 1989: SPENT FUEL AND RADIOACTIVE WASTE INVENTORIES, PROJECTIONS AND CHARACTERISTICS

INTEGRATED DATA BASE FOR 1986: SPENT FUEL AND RADIOACTIVE WASTE INVENTORIES, PROJECTIONS, AND CHARACTERISTICS

INTEGRATED DATA BASE FOR 1987: SPENT FUEL ANB RADIOACTIVE WASTE INVENTORIES, PROJECTIONS, AND CHARACTERISTICS

STATEMENT OF WORK FOR GROUT TREATMENT FACILITY CHARACTERIZATION PROJECT FOR FISCAL YEAR 1992 


\begin{tabular}{|c|c|c|}
\hline $\begin{array}{l}\text { TFIIINQ10 } \\
\text { USER ID }=84969\end{array}$ & TFI Selection Report & $\begin{array}{l}\text { Date } 11 / 15 / 93 \\
\text { Time } 14.33 .01\end{array}$ \\
\hline
\end{tabular}

WTS \# Document Number

293-004717 SD-M-LB-004

293-004736 PNL-013174

$293-00475693353176$

293-004873 MM-112989

293-004896 65413-79-161

$293-004898 \quad 65413-79-193$

$293-00500265611-84-167$

293-005017 PAPER-XXXXXXX

293-005050 DOE/RW-0074

293-005051 DOE/RW-0074

293-005089 DOE/RW-0074

293-005090 DOE/RW-0074

293-005206 80322-89-160

293-005207 13230-89-TDB-226

293-005348 REP-XXXXXXX

$293-005360$ DSI-121589
Author Name

BOWTON

COLEMAN

PROPSON

G.L. DUNFORD

GOLD

GOLD

SASAKI

JANSKR

DOE

$05 / 01 / 86$

$05 / 01 / 86$

$05 / 01 / 86$

$05 / 01 / 86$

CARPENTER

BAUMHARDT

$08 / 25 / 89$

BLANKENSHIP

CARPENTER

$08 / 28 / 89$.

GIBBY

WODRICH

$12 / 15 / 89$
Document Title

WASTE TANK CHARACTERIZATION PROGRAM SAMPLE HANDLING AND ANALYSIS PLAN

ACOUSTICAL HOLOGRAPHY FOR THE CHARACTERIZATION OF THE CONTENTS OF NUCLEAR WASTE TANKS

DELIVERY OF TWO SINGLE-SHELL TANK CHARACTERIZATION REPORTS

ENGINEERING HELP ON STREAM CHARACTERIZATION REPORT

DOUBLE SHELL SLURRY CHARACTERISTICS OF PUREX CAMPAIGN MATERIAL

DOUBLE SHELL SLURRY CHARACTERISTICS OF PUREX CAMPAIGN MATERIALS

SLURRY GROWTH MONITORING AND CHARACTERIZATION OF DOUBLE SHELL SLURRY FROM THE UPCOMING DOUBLE SHELL SLURRY RUN

SLURRY GROWTH: THE CHARACTERIZATION OF A UNIQUE PHENOMENON AT THE HANFORD SITE

A MULTIATTRIBUTE UTILITY ANALYSIS OF SITES NOMINATED FOR CHARACTERIZATION FOR THE FIRST RADIOACTIVEWASTE REPOSITORY--A DECISION-AIDING METHODOLOGY

A MULTIATTRIBUTE UTILITY ANALYSIS OF SITES NOMINATED FOR CHARACTERIZATION FOR THE FIRST RADIOACTIVE - WASTE REPOSITORY - A DECISION-AIDING METHODOLOGY

A MULTIATTRIBUTE UTILITY ANALYSIS OF SITES NOMINATED FOR CHARACTERIZATION FOR THE FIRST RADIOACTIVE

- WASTE REPOSITORY - A DECISION-AIDING METHODOLOGY

A MULTIATTRIBUTE UTILITY ANALYSIS OF SITES NOMINATED FOR CHARACTERIZATION FOR THE FIRST RADIOACTIVE

- WASTE REPOSITORY - A DECISION AIDING METHODOLOGY

ENVIRONMENTAL ASSURANCE ASSESSMENT: WASTE CHARACTERIZATION FOR CROSS-SITE TRANSFER

WASTE CHARACTERIZATION FOR CROSS-SITE TRANSFER

SOLIDIFICATION PROCESSES PHOSPHATE VS CLAY -PRODUCT CHARACTERISTICS RELATIVE TO SALT CAKE

WHAT WE KNOW ABOUT CONTENT OF SINGLE SHELL TANKS BASED ON CHARACTERIZATION DATA 
WTS \# Document Number

293-005470 PNL-8560

293-005471 PNL-8560

$293-005513 \quad$ ECN-163837

293-005771 SD-WM-TP- 117

293-005833 SD-WM-TI-213

293-005945 ECN-163834

293-005973 MM-061185

293-0060089354378 DRAFT

293-006018 WHC-WP-0643

293-0060289354378 DRAFT

293-006255 WHC-SD-DD-TI-040 REV CUMMINGS

293-006429 LET-022476

293-006444 L.ET- 111676

293-006452 LET-031676

293-006465 LET-010876

293-006477 13841-89-003

293-006540 0105

293-006565 9354296
Author Name

QUADREL

QUADREL

HENDR I CKSON

HENDR ICKSON

STEINER

HANSON

MOBLEY ET AL

BROWN ET AL

MOBLEY ET AL

HORTON

HORTON

HORTON

BRUNS

STROPE

ALL̇EN

WELLS
Addressee Name Doc Date No

04/01/93

$04 / 01 / 93$

03/09/92

$01 / 01 / 920$

DILIBERTO $\quad 12 / 05 / 85$

DISTRIBUTION $\quad 02 / 11 / 92$

DILIBERTO

$06 / 11 / 85$

$05 / 27 / 93$

$04 / 01 / 93$

$05 / 27 / 93$

$06 / 30 / 89 \cdot 0$

CHRISTENSEN

$02 / 24 / 76$

CHRISTENSEN

$11 / 16 / 76$

CHRISTENSEN

$03 / 16 / 76$

JENSEN

$01 / 08 / 76$

BARRINGTON

$01 / 12 / 89$

MCKENZIE

$09 / 09 / 77$

RUTHERFORD
$05 / 28 / 93$

\section{Document Title}

AN UNDERGROUND STORAGE TANK INTEGRATED DEMONSTRATION REPORT VOLUME 1: WASTE CHARACTERIZATION DATA AND TECHNOLOGY DEVELOPMENT NEEDS ASSESSMENT SEC 10F2

AN UNDERGROUND STORAGE TANK INTEGRATED DEMONSTRATION REPORT VOLUME 1: WASTE CHARACTERIZATION DATA AND TECHNOLOGY DEVELOPMENT NEEDS ASSESSMENT SEC $20 \mathrm{~F} 2$

ECN-163837 TO TANK 241-AP-106 SAMPLING AND CHARACTERIZATION PLAN

TANK AP106 SAMPLING AND CHARACTERIZATION PLAN

EVALUATION OF THE SYNTHETIC PLUTONIUM FINISHING PLANT WASTE CHARACTERIZATION

TANK 241-AP-106 SAMPLING AND CHARACTERIZATION PLAN - ENGINEERING CHANGE NOTICE

CHARACTERIZATION OF AGING WASTE

TANK WASTE CHARACTERIZATION PROGRAM PLAN - DRAFT SECTION 2 OF 2

ANK CHARACTERIZATIO

TANK WASTE CHARACTERIZATION PROGRAM PLAN - DRAFT SECTION 1 OF 2

TANK 241-CX-72 PRELIMINARY WASTE CHARACTERIZATION CHARACTERIZATION AND ANALYSIS OF TANK S104 SLUDGE ANALYSIS AND CHARACTERIZATION OF B361 TANK SLUDGE CHARACTERIZATION AND ANALYSIS OF BY104 TANK SLUDGE T101 CHARACTERIZATION

CHARACTERIZATION OF PLUTONIUM FINISHING PLANT HASTE STREAMS

ISOLATION AND STABILIIZATION PROGRAM NEEDS FROM THE WASTE CHARACTERIZATION PROGRAM

CHANGE REQUEST TWR-N93-032 "COMPREHENSIVE CHANGES TO CHARACTERIZATION MILESTONES" 


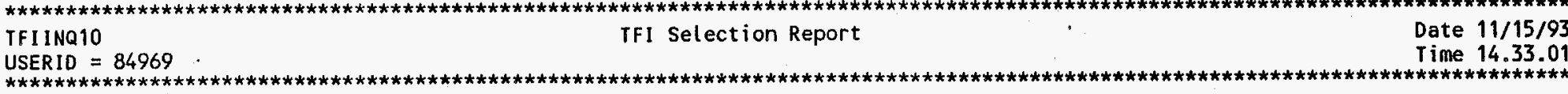

WTS \# Document Number

293-006598 65453-85-205

293-006771 SD-WM-T1-215

293-006801 UHC-WP-0643

293-0068239354442

293-006910 WHC-EP-0640

293-0069689354389

293-0069719355035

293-006973 WHC-EP-0640

293-007057 SD-UM-II - 213

293-0070789157948

293-0071129352130

$293-00717560440-79-104$

293-007176 RHO-122178

293-007186 14120

293-007188 13557

293-007189 12545-R6

293-007190 LET-080779
Author Name

BRATZEL

Addressee Name Doc Date No

KIMURA

BROW ET AL

WELLS

RUTHERFORD

SIMPSON ET AL

SASAK 1

MCKILEY

MOBLEY

VICKERY

SIMPSON ET AL

EAKEF :

ARTHUR

GERTON

GUSTAVSON

KASER

COCKE-RAM

ELGERT

WOORICH

$12 / 12 / 79$

$09 / 07 / 79$

WODRICH

HAUGHNEY

$08 / 08 / 79$

PITT

SUTEY
Document Title

WASTE TANK CHARACTERIZATION SAMPLE. BREAKDOWN RATES

0 CHARACTERIZATION OF SELECTED DOUBLE-SHELL TANK VAPOR SPACE RADIONUCLIDES

TANK CHARACTERIZATION FOR SINGLE-SHELL. TANK 241-U110 SECTION 1 OF 2

CHANGE REQUEST TWR-N93-035 CHANGE CHARACTERIZATION MILESTONE 4310 AND. DELETE MILESTONE 4304

TANK CHARACTERIZATION REPORT: TANK 241-C-112 SECTION 1 OF 2

PNL PROCEDURES FOR CHARACTERIZATION IN SUPPORT OF TWRS TWCP

ESTIMATES FOR SUPPORT OF TANK WASTE CHARACTERIZATION

TANK CHARACTERIZATION REPORT: TANK 241-C-112 SECTION 2 OF 2

12/05/85 0 EVALUATION OF THE SYNTHETIC PLUTONIUM FINISHING PLANT WASTE CHARACTERIZATION DATE

LETTER OF INSTRUCTION FOR RADIOLOGICAL ASSAY SERVICES AND CHARACTERIZATION STUDIES PER WORK ORDER E02152

ENVIRONMENTAL ASSESSMENT - TANK 241-C-103 VAPOR PHASE CHARACTERIZATION

NUCLEAR FUELS SERVICES, INC. WASTE AND TANK CHARACTERIZATION PLANNING TEAM

PROPOSAL TO NUCLEAR REGULATORY COMMISSIONER FOR CHARACTERIZATION OF NUCLEAR FUEL SERVICE NFS WASTE TANKS, CONTRACT EY-77-C-06-1030

CHARACTERIZATION OF NUCLEAR FUEL SERVICES, INC. NFS TANKS, WASTE, AND SOIL, OCTOBER 1979 MONTHLY REP

PHYSICAL CHARACTERISTICS OF WASTE TANK AND CONTENTS AT WEST VALLEY

CHARACTERIZATION OF NUCLEAR FUEL SERVICES, INC. TANKS, WASTE, AND SOIL

SCHEDULE 169 FOR PHYSICAL CHARACTERISTICS OF WASTE TANKS AND CONTENTS-WEST VALLEY, NEW YORK CONTRACT

EY-77-C-06-1030 
WTS \# Document Number

293-007191 13327

293-007192 13332

293-007194 13097

293-007195 REP-112778

293-007197 LET-051179

293-007199 12927

293-007200 12854

293-007202 LET-033079

293-007203 R79-0748

293-007204 12169-R

293-007205 60440-79-109

293-007225 60400-79-012

293-007226 60440-79-130

293-007227 RHO-030979

293-007232 9205490B R8

293-007234 9302231B

293-007279 $65453-84-374$
Author Name

HAUGHNEY

HAUGHNEY

HAUGHNEY

WOORICH

HAUGHNEY

HAUGHNEY

:

HARRIS

WODRICH

WODRICH

HARRIS

KASER

KOSIANCIC

KASER

REEP

RICHARDSON

WAGONER

ANDERSON

$03 / 02 / 93$

BRATZEL

TULBERG

$12 / 31 / 84$
$06 / 12 / 79$

$11 / 27 / 78$

$05 / 11 / 79$

$03 / 05 / 938$

\section{Rev}

$7 / 26 / 79$

$07 / 27 / 79$

05/07/79

$04 / 27 / 79$

$03 / 30 / 79$

$03 / 25 / 79$

$02 / 21 / 79$

03/02/79

$03 / 15 / 79$

03/09/79

$3 / 02 / 93$

Document Title

CHARACTERIZATION OF NUCLEAR FUEL SERVICES, INC NFS TANKS, WASTE AND SOIL

CHARACTERIZATION OF NUCLEAR FUEL SERVICES, INC NFS TANKS, WASTE AND SOIL

CHARACTERIZATION OF NUCLEAR FUEL SERVICES, INC. NFS TANKS, WASTE, AND SOIL, APRIL 1979 MONTHLY REPORT

STATEMENT OF WORK FOR PHYSICAL CHARACTERISTICS OF WASTE TANK AND CONTENTS AT WEST VALLEY

CHARACTERIZATION OF NUCLEAR FUEL SERVICES, INC. TANKS, WASTE, AND SOIL

CHARACTERIZATION OF NUCLEAR FUEL SERVICES, INC. NFS TANKS, WASTE, AND SOIL, MARCH 1979 MONTHLY REPORT

PHYSICAL CHARACTERISTICS OF WASTE TANK AND CONTENTS AT WEST VALLEY

CHARACTERIZATION OF NUCLEAR FUEL SERVICES, INC. TANKS, WASTE, AND SOIL

INSPECTION OF TANKS AND CHARACTERIZATION OF SOIL AND RADIOACTIVE WASTES AT WEST VALLEY, NEW YORK

PHYSICAL CHARACTERISTICS OF WASTE TANK AND CONTENTS AT WEST VALLEY

NUCLEAR FUELS SERVICES, INC. WASTE AND TANK CHARACTERIZATION PLANNING TEAM

TEAM FOR PLANNING PHASE OF NUCLEAR FUELS SERVICES INC. WASTE AND TANK CHARACTERIZATION WORK

MEETINGS ON PROPOSAL TO NUCLEAR REGULATORY COMMISSIONER TO CHARACTERIZE HIGH-LEVEL WASTE AND TANKS AT WEST VALLEY, NEW YORK

MEETINGS ON PROPOSAL FOR INSPECTION OF TANKS AND CHARACTERIZATION OF SOIL AND WASTE AT WEST VALLEY NEW YORK

TANK WASTE CHARACTERIZATION STRATEGIC PLAN

AUTHORIZATION FOR CHARACTERIZATION OF RISER 12A. IN TANK 241-SY-101

CHARACTERIZATION OF TK 102-SY SUPERNATANT, R-3326 


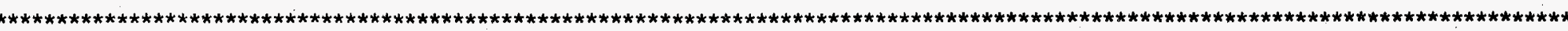

TFIINQ10 TFI Selection Report' Date 11/15/93

USERID $=84969$

Time 14.33.01

WTS \# Document Number

Author Name

Addressee Name Doc Date No

Document Title

293-007296 RHO-RE-SA-216 P

KIMURA

293-0073629305207

293-0073789354378.1

293-007385 9352130.1

MCKINLEY

SASAKI

PROPSON

GERTON

GERTON

FULTON

293-007588 DOE/RW-0006 REV. O OAK RIDGE NATIO

293-007753 DOE/RW-0006 REV. O OAK RIDGE NATIO

293-007865 DOE/RW-0006 REV. 0 OAK RIDGE NATIO

293-0079029353716

$293-0079039353658$

293-007975 DOE/RW-0006 REV. O OAK RIDGE NATIO

DUCHSHERER

293-008859 ECN-185863

RICHAROSON

GERTON

293-0095039205490B R3

OAK RIDGE NATIO DISTRIBUTION

293-010849 DOE/RW-0006 REV 7 OAK RIDGE NATIO DISTRIBUTION

293-010850 DOE/RW-0006 REV 7 OAK RIDGE NATIO DISTRIBUTION
$06 / 01 / 87$

$06 / 14 / 93$

$06 / 24 / 93$

$06 / 23 / 93$

$11 / 01 / 89$

$11 / 01 / 89$

$11 / 01 / 89$

$04 / 30 / 93$

$04 / 30 / 93$

$11 / 01 / 89$

$05 / 10 / 93$

$10 / 29 / 92$

$10 / 01 / 917$

$10 / 01 / 917$

$10 / 01 / 917$
CHARACTERIZATION OF AIRBORNE RADIONUCLIDE PARTICULATES IN VENTILATED LIOUID WASTE TANKS

CHARACTERIZATION ACTIVITY PROCEDURES

TANK WASTE CHARACTERIZATION PROGRAM PLAN

ENVIRONMENTAL ASSESSMENT: TANK 241-C-103 ORGANIC VAPOR AND LIQUID CHARACTERIZATION AND SUPPORTING ACTIVITIES, HANFORD SITE, RICHLAND, WASHINGTON

INTEGRATED DATA BASE FOR 1989: SPENT FUEL AND RADIOACTIVE WASTE INVENTORIES, PROJECTIONS, AND CHARACTERISTICS SECTION 1 OF 4

INTEGRATED DATA BASE FOR 1989: SPENT FUEL AND RADIOACTIVE WASTE INVENTORIES, PROJECTIONS, AND CHARACTERISTICS SECTION 2 OF 4

INTEGRATED DATA BASE FOR 1989: SPENT FUEL AND RADIOACTIVE WASTE INVENTORIES, PROJECTIONS, AND CHARACTERISTICS SECTION 3 OF 4

COMPLETION OF MILESTONE \#4356--COMPENDIUM OF HISTORICAL CHARACTERIZATION DATA

COMPLETION OF MILESTONE \#4355 - DELIVERY OF TWO SINGLE-SHELL TANK CHARACTERIZATION REPORTS

INTEGRATED DATA BASE FOR 1989: SPENT FUEL AND RADIOACTIVE WASTE INVENTORIES, PROJECTIONS, AND CHARACTERISTICS SECTION 4 OF 4

TECHNICAL PROJECT PLAN FOR THE 222-S LABORATORY IN SUPPORT OF THE GROUT TREATMENT FACILITY SAMPLING AND CHARACTERIZATION PLANS FOR TANKS 105-AP, 106-AP

WASTE TANK CHARACTERIZATION STRATEGIC PLAN

INTEGRATED DATA BASE FOR 1991: U.S. SPENT FUEL AND RADIOACTIVE WASTE INVENTORIES, PROJECTIONS, AND CHARACTERISTICS SECTION 1 OF 4

INTEGRATED DATA BASE FOR 1991: U.S. SPENT FUEL AND RADIOACTIVE WASTE INVENTORIES, PROJECTIONS, AND CHARACTERISTICS SECTION 2 OF 4

INTEGRATED DATA BASE FOR 1991: U.S. SPENT FUEL AND RADIOACTIVE WASTE INVENTORIES, PROJECTIONS, AND CHARACTERISTICS SECTION 3 OF 4 


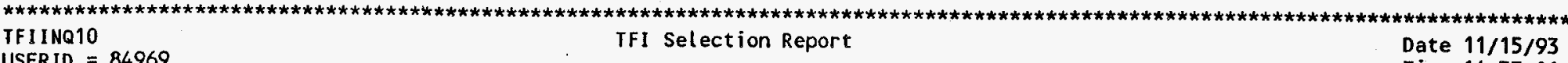

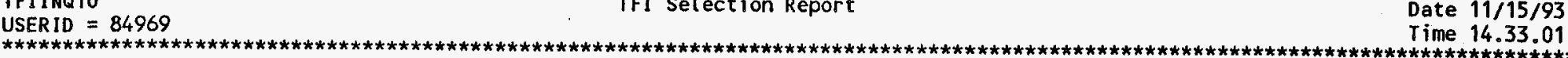

WTS \# Document Number Author Name Addressee Name Doc Date No Document Title

-293-010851 DOE/RW-0006 REV 7 OAK RIDGE NATIO DISTRIBUTION 10/01/91 7 INTEGRATED DATA BASE FOR 1991: U.S. SPENT FUEL AND - RADIOACTIVE WASTE INVENTORIES, PROJECTIONS, AND

$293-011473 \quad 65455-85-069$

BULLOUGH STEINER 061185

ESTIMATE FOR EVALUATING MIXER CHARACTERISTICS OF JET AGITATOR BRSTEM IN DCRT

369 RECORDS LISTED

$\star \star \star \star \star$ END OF REPORT $\star * \star *$ 